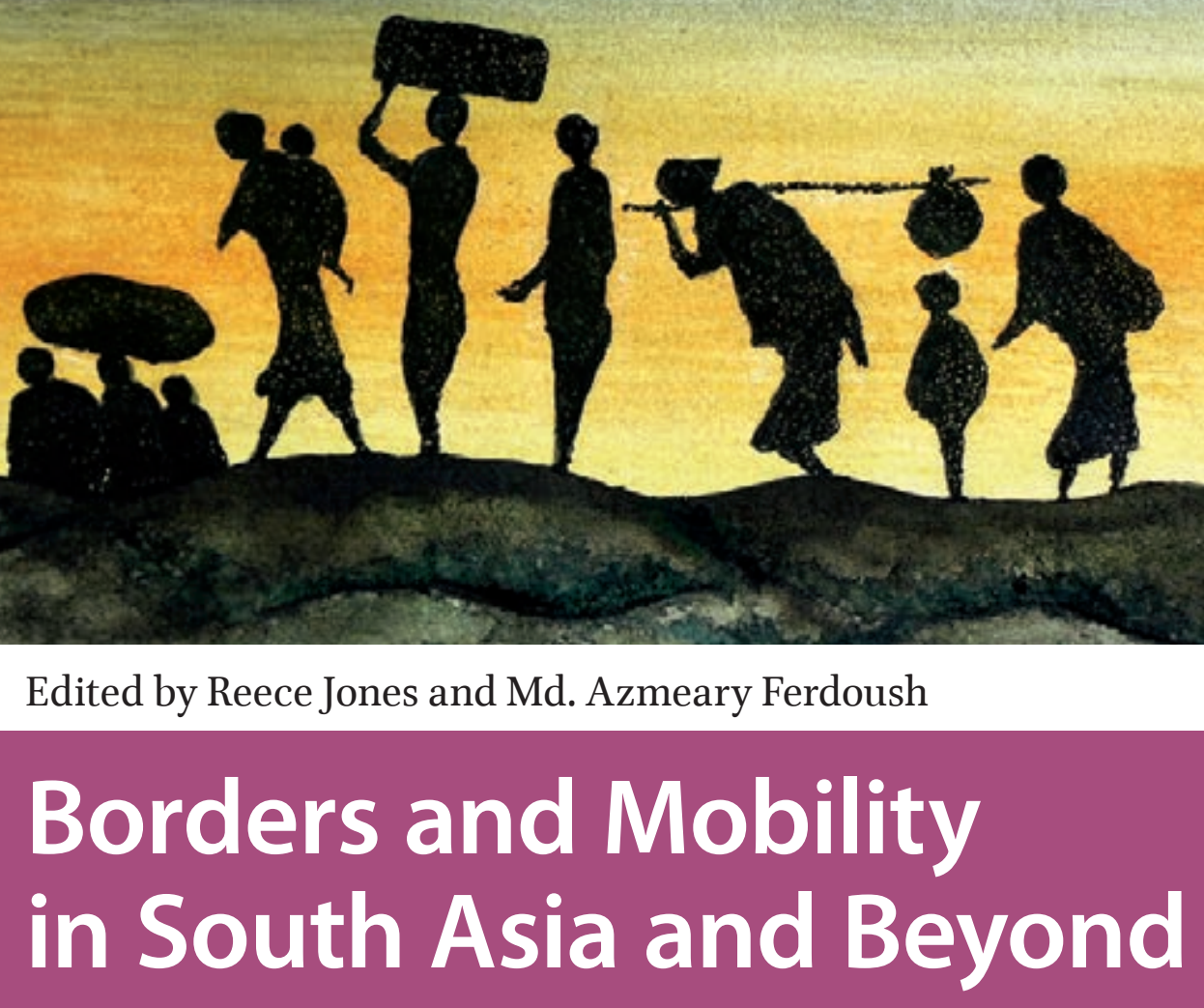


Borders and Mobility in South Asia and Beyond 


\section{Asian Borderlands}

Asian Borderlands presents the latest research on borderlands in Asia as well as on the borderlands of Asia - the regions linking Asia with Africa, Europe and Oceania. Its approach is broad: it covers the entire range of the social sciences and humanities. The series explores the social, cultural, geographic, economic and historical dimensions of border-making by states, local communities and flows of goods, people and ideas. It considers territorial borderlands at various scales (national as well as supra- and sub-national) and in various forms (land borders, maritime borders), but also presents research on social borderlands resulting from border-making that may not be territorially fixed, for example linguistic or diasporic communities.

Series Editors

Tina Harris, University of Amsterdam

Willem van Schendel, University of Amsterdam

Editorial Board Members

Franck Billé, University of California, Berkeley

Duncan McDuie-Ra, University of New South Wales

Eric Tagliacozzo, Cornell University

Yuk Wah Chan, City University Hong Kong 


\title{
Borders and Mobility in South Asia and Beyond
}

\author{
Edited by \\ Reece Jones and Md. Azmeary Ferdoush
}


Cover illustration: Asad Zaman

Cover design: Coördesign, Leiden

Lay-out: Crius Group, Hulshout

$\begin{array}{ll}\text { ISBN } & 9789462984547 \\ \text { e-ISBN } & 9789048535224 \text { (pdf) } \\ \text { DOI } & 10.5117 / 9789462984547 \\ \text { NUR } & 761\end{array}$

(c) $(1) \Theta$

Creative Commons License CC BY NC ND (http://creativecommons.org/licenses/by-nc-nd/3.o)

@ The authors / Amsterdam University Press B.V., Amsterdam 2018

Some rights reserved. Without limiting the rights under copyright reserved above, any part of this book may be reproduced, stored in or introduced into a retrieval system, or transmitted, in any form or by any means (electronic, mechanical, photocopying, recording or otherwise). 


\section{Table of Contents}

Acknowledgements

Introduction

The Global Transformation of Borders and Mobility

Reece Jones and Md. Azmeary Ferdoush

\section{Section I Experiencing Borders in South Asia}

1 Spaces of Refusal

Rethinking Sovereign Power and Resistance at the Border Reece Jones

2 Border Layers

Formal and Informal Markets Along the India-Bangladesh Border Edward Boyle and Mirza Zulfiqur Rahman

3 Experiencing the Border

The Lushai People and Transnational Space

Azizul Rasel

\section{Section II Mobility in and Beyond South Asia}

4 Of Insiders, Outsiders, and Infiltrators

The Politics of Citizenship and Inclusion in Contemporary South Asia Kavitha Rajagopalan

5 Renegotiating Boundaries

Exploring the Lives of Undocumented Bangladeshi Women Workers in India

\section{Ananya Chakraborty}

6 'The Immoral Traffic in Women' 
7 The Journey to Europe

A Young Afghan's Experience on the Migrant Route

James Weir and Rohullah Amin

8 Hardening Regional Borders

Changes in Mobility from South Asia to the European Union

Marta Zorko

\section{Section III Representations of Borders and Mobility in Diaspora}

9 The Borders of Integration

Paperwork between Bangladesh and Belgium

Malini Sur and Masja van Meeteren

10 Disordering History and Collective Memory in Gunvantrai

Acharya's Dariyalal

Riddhi Shah

11 Fragmented Lives

Locating 'Home' in the Poems of Sudesh Mishra

Tana Trivedi

Conclusion

267

Md. Azmeary Ferdoush and Reece Jones

Index

\section{List of Figures}

Figure 2.1 Land Customs Stations in Northeast India

Figure 2.2 Locations of Border Haats along the India-Bangladesh Border

Figure 3.1 The Chittagong Hill Tracts

Figure 3.2 The Sajek Valley

Figure 7.1 Typical Afghan Transportation $\quad 175$

$\begin{array}{ll}\text { Figure 7.2 Akbar's Route to Europe } & 179\end{array}$

Figure 10.1 Ramjibha's Identity Tangent 242 


\section{Acknowledgements}

Putting together a book involves the work of many people at multiple stages of the process. We want to thank Saskia Gieling and the editors at Amsterdam University Press for supporting the book and shepherding it to publication. Thanks also to the Asian Borderlands Series editors, Willem van Schendel and Tina Harris, for their support of the project. Asad Zaman designed and drew the book cover image. Thanks to Julius Paulo for making the maps for Figures 3.1 and 7.2. The original idea for this book was hatched at the University of Hawai'i Centre for South Asian Studies Symposium in Honolulu, which was funded by the Centre for South Asian Studies and the GJ \& Ellen Watumull Foundation. Thanks particularly to Akta Kaushal and Monica Ghosh for their organizational efforts and support.

Reece Jones thanks Sivylay, Kiran, and Rasmey for allowing the time for the research and writing that went into this project. Thanks also to my parents, Wally and Celia, for their continuing support. Chapter 1, 'Spaces of Refusal: Rethinking Sovereign Power and Resistance at the Border', originally appeared in the Annals of the Association of American Geographers in 2012, volume 102(3), pp. 685-699. It is reprinted with permission. Thanks to Thomas Belfield, Adam Moore, and Lisa Romano for reading and commenting on earlier versions of this chapter. The findings of the chapter are based in part on work supported by the US National Science Foundation under Grant No. 0602206, the American Institute of Bangladesh Studies, and the Political Geography Specialty Group of the American Association of Geographers.

Md. Azmeary Ferdoush thanks his parents for their life-long support and help and acknowledges his wife Morsaline for being a source of immense inspiration all the way through. Azmeary is grateful to the Centre for South Asian Studies at UH Manoa, the East-West Centre, the Department of Geography and Environment at UH Manoa, and the Graduate Student's Organization at UH Manoa for partially supporting his work. Last but not the least, he thanks his adviser, who has not only been a great mentor but also a great person to collaborate with.

Edward Boyle wishes to acknowledge the financial support of Kyushu University's Short-term International Research Exchange Program, which enabled the field trip to Northeast India that made this collaborative venture possible. Mirza Zulfiqur Rahman also wishes to acknowledge his gratitude for the opportunity to visit the field afforded by this program. Material in this chapter was initially presented by Edward Boyle as part of the Borders and Sovereignty panel at the American Association of Geographers Annual 
Meeting in San Francisco, 29 March-02 April, 2016. Attendance was made possible by a Kyushu University Interdisciplinary Programs in Education and Projects in Research Development (P\&P) grant, Project No. 27503.

Azizul Rasel is indebted to the University of Liberal Arts Bangladesh, and particularly Vice Chancellor H.M. Jahirul Haque, for the partial grant in support of this research. He is grateful to his colleagues Salimullah Khan, Syeda Nishita Aurnab, and Rigan Chakma for their useful comments and Rumana Sharmin, Aminul Sazal, and Sharmina Nasrin for their constant support and encouragement. He is thankful to Razin Khan for sending him valuable books from London. His debt to his friend David Lushai is boundless, as he helped to organize interviews in the Sajek Valley.

Kavitha Rajagopalan acknowledges that many of the ideas in this chapter emerged in conversation and collaboration with many thoughtful scholars. In particular, she would like to acknowledge her colleagues Greg Lindsay and Kate Maloff at the World Policy Institute for their collaboration on the Emergent Cities Initiative, and Dr. Michael Ignatieff and Devin Stewart at the Carnegie Council for Ethics in International Affairs for their leadership in a multi-year inquiry into the global ethics surrounding migration and citizenship. Special thanks are owed for the insights and introductions of Kathryn Stam and Chris Sunderlin in Utica, and for the generosity of Shyam Rai and his family. She is grateful for the guidance and mentorship of Dr. Edmund W. Gordon, and for the love and support of her husband, Matthew Young, and her two children, Leela and Krishna.

Ananya Chakraborty is grateful to Dr. Sandhya Iyer and the Late Prof. Sharit Bhowmik for their valuable suggestions in conceptualizing this paper. She is also thankful for the valuable suggestions of two anonymous referees. Finally, she would like to thank the editors of this book for their patience and constant guidance. The usual disclaimers apply.

Andrea Wright acknowledges that this project was funded by a FulbrightHays Doctoral Dissertation Research Abroad Fellowship. She thanks the staff at the National Archives of India, Aligarh Muslim University, and the Dubai School of Government for their support of the research for this chapter. At the University of Michigan, she thanks Rackham Graduate School, the Ross School of Business's Centre for International Business Education, the Trehan India Initiative, and the Interdepartmental Program in Anthropology and History for their generous support. Versions of this article were presented at the Association for Asian Studies Conference (Philadelphia) and the South Asia by the Bay Conference (Palo Alto), and she is grateful to the audiences and organizers for their feedback. She is indebted to Alexandre Beliaev, William Benton, David William Cohen, Juan Cole, Matthew Hull, Elizabeth 
Kelly, Purvi Mehta, and Farina Mir for their comments and suggestions on earlier versions of this chapter.

Marta Zorko would like to thank every interviewed person who shared their story to make this chapter insightful. She would especially like to thank those who withdrew their statements afterwards because of fear for their legal status, work, or even life. This made her realize the real importance of the topic. She would also like to thank her travel companion for overall support during the research and for being brave enough to ask the questions that she sometimes did not have the courage to ask. Finally, many thanks to the editors for the patience and effort toward realizing this book.

Malini Sur and Masja van Meeteren thank Hans Sonneveld and Willem van Schendel for encouraging collaborative research and the anonymous reviewers for their valuable suggestions.

Tana Trivedi would like to thank Ahmedabad University for giving her the academic space to pursue her research, and her family for their unstinting support and love. 



\section{Introduction}

The Global Transformation of Borders and Mobility

Reece Jones and Md. Azmeary Ferdoush

Jones, Reece and Ferdoush, Md. Azmeary (eds), Borders and Mobility in South Asia and Beyond. Amsterdam: Amsterdam University Press, 2018 DOI: 10.5117/9789462984547/INTRO

The migration 'crisis' of the mid-2010s featured many familiar stories: Syrians fleeing the war that destroyed their homes; Central Americans escaping gang violence to find safety in the north; Eritreans fleeing a totalitarian regime that prohibits emigration; hundreds of thousands of Rohingya crossing into Bangladesh from Myanmar; and migrants from Sub-Saharan Africa leaving the lingering poverty of colonial exploitation to search for better opportunities elsewhere. This book seeks to broaden and deepen the story of migration in the twenty-first century by focusing on the experiences of the people from South Asia who have played a significant role in global migrations, but received less attention in academic and media accounts. Despite the international media's focus on people from Syria, people from Afghanistan make up the largest group stranded along the route through the Balkans after the closure of borders and construction of walls in 2015 . In 2016, Pakistanis were the second largest group of refugees in Serbia (United Nations, High Commissioner for Refugees 2016). In the Middle East, people from South Asia make up the vast majority of the workers building skyscrapers, artificial islands, and stadiums for the 2022 FIFA World Cup. In the first half of 2017, the largest single group crossing the Mediterranean from Libya to Italy were not from the Middle East or Africa, but Bangladesh (Dearden 2017).

Indeed, if you look for it, the Bangladeshi population is visible in all of the major cities of Italy. ${ }^{1}$ In Rome, Bangladeshi men dominate the area around the Colosseum, selling selfie sticks, bottled water, and souvenirs to tourists. In Florence, many of the small convenience stores are run by Bangladeshis, as are the majority of the stalls selling leather goods and

1 Reece Jones conducted research in Italy in summer 2017, including interviews with Bangladeshis. 
football jerseys at the Mercato San Lorenzo. In Milan, an Italian colleague noted that she had assumed that there were many Indian migrants, but many had turned out to be from Bangladesh. Even before the current wave of migration, Bangladeshis already made up the second largest nonEuropean population in Italy (after Nigerians), with over 142,00o people living there with status. This population has tripled in just the past seven years and is projected to increase to 232,000 by 2030. It is also estimated that, as of 2009, at least 11,000 additional Bangladeshis were living in Italy without any legal status (Blangiardo 2009). The Bangladeshi migrants in Italy are overwhelmingly male ( 72 per cent) and, with an average age of 28 years, are mostly young adults looking for better chances in life (Rahman \& Kabir 2012). In addition to those arriving on boats from Libya - where many originally went to work in the oil industry, not to come to Europe -, others first went to the United Kingdom as students, or to Germany to apply for asylum. After their attempts to settle elsewhere ended or were denied, they came to Italy following their connections with the alreadyestablished population.

Once they arrive in Italy, Bangladeshis without a legal status face a daunting life of scraping by on the edges of society, relying on the existing community for shelter and work opportunities. In addition to selling goods on the streets to tourists, many Bangladeshis work as cooks in the kitchens of tourist-oriented Italian restaurants. Those with status have access to more jobs, but still struggle to adapt to a new way of life with different expectations for behaviour and social interactions. As their new home changes them, they also maintain connections to their relatives in Bangladesh, sending home remittances and keeping abreast of political and cultural events. Their new life can be simultaneously invigorating and exasperating, as opportunities and wealth compete with lower status, racial biases, and a longing for home. As a 24-year-old who had been in Europe for two years without status explained, 'The pay is good, but I miss all of my family at home.'

The story of these Bangladeshis - who undertake a dangerous journey, apply for asylum but are rejected, and then live without documents in Rome or Florence - is representative of the larger questions the contributors grapple with in this book. Globally, the world is experiencing one of the largest movements of people in history and a large proportion of those migrants are from South Asia. The factors that drive people to move include: wars over resources; global income divergence, as the gap between the wealthiest and the poorest continues to grow; population growth, which pushes more people out of rural areas into crowded cities in search of jobs; conflict over 
artificial borders that are the remnants of colonialism; and the spectre of climate change-induced migration, which could potentially displace hundreds of millions of people. In this context, the overall contribution of this volume is to answer the question: In an age of globalmigration, economic flows, and information exchange, how do borders and restrictions on mobility affect the lives of people from South Asia and beyond?

The chapters collected here answer this question by looking at migrants' current situation at a range of scales and from distinct vantage points. The first section of the book considers the lingering impact of Partition on borders in South Asia, seventy years after that tumultuous event. How do people move through these South Asian border spaces? How do the lines on the map, and the increasingly militarized borders on the ground, affect people's lives? How do borderland people and sovereign states cope with the reality that people and goods continue to move across these borders? The second section of the book turns to longer-distance migrations, describing the contemporary experiences of people from South Asia as they take part in the global movement of people. Why have so many people decided to move? How have the hardened borders of walls, guards, and surveillance technologies impacted their journeys? How do factors of ethnicity, gender, and religion shape their experiences once they arrive in their destinations? Finally, the third section of the book goes deeper into the experiences of diaspora communities who have resided for long periods in new homes. How do people in the South Asian diaspora represent their current and past homes? How are connections to the past maintained, and how do these connections constrict and enable their lives today? Throughout the book we draw on the stories and experiences of people on the move to illustrate how new borders, migration, and citizenship policies affect the lives of individuals around the world.

\section{Theorizing Borders, Mobility, and Place in South Asia and Beyond}

To answer these questions, this introduction situates the chapters within three distinct but closely related bodies of literature. First, by focusing on the experiences of borderlanders and migrants, this book provides a snapshot of the precarious lives of people who move, both within South Asia and globally from South Asia to Europe and North America. Drawing on recent trends in critical border studies, we argue that the hardening of borders does not stop the movement of people; instead, it only makes movement more risky and dangerous as people find new ways through and 
around border restrictions. Second, the book engages with the literature on borders and mobility to demonstrate that migration from South Asia is a gendered experience, in terms of both who is able to move and their experiences at their destinations. Experiences of the journey - both en route and at the destination - also vary widely, depending on factors such as age, national origin, religious identity, and whether one has valid documents. Finally, it engages with the literature on place-making to argue that South Asian diaspora populations are in a constant process of making both where they currently live and, through representations, their distant, and often unknown, ancestral homes.

\section{Migration in the Age of Security and Walls}

The global movement of people and the violent and exclusionary responses of states have attracted substantial scholarly attention to the expansion of security practices and their impact on people on the move. In 2016, over 7900 people died while attempting to cross a border, the largest number ever recorded. In 2017, there were 5400 deaths at borders around the world. ${ }^{2}$ The United Nations High Commissioner for Refugees reported that there were over 65.6 million people displaced globally in 2016 , also a record (United Nations High Commissioner for Refugees 2016). In response to these movements, border security has emerged as a key political issue in countries around the world. Donald Trump rode his campaign promise to build a wall on the Mexico border to the presidency of the United States. In the United Kingdom, voters opted to leave the European Union over fears of migration and open borders. Across Europe, countries have built walls, instituted new security procedures, and even closed internal border crossings that had been open since the late 1990s. In 2012, there were about 35 border walls globally; in 2017, there are almost 70 (Jones 2016; Jones \& Johnson 2016; Vallet 2014). The idea that globalization would produce a world of free movement of goods and people was in retreat as anti-migrant nationalism and anti-trade protectionism emerged as key political positions in many countries.

Recent interventions into the political geography of border spaces have suggested that these changes to the politics and practices of borders have transformed contemporary migration experiences (Johnson et al. 2011;

2 Missing Migrants Project, International Organization for Migration. https://missingmigrants. iom.int. This database is drawn from media reports on deaths and is therefore critiqued for being incomplete and dependent on the ebb and flow of coverage. 
Parker \& Williams 2009). Mobility is now characterized by new corridors, camps, and spaces of confinement that funnel migrants toward specific locations and violently restrict the easiest routes to their destinations (Jones et al. 2017). These new geographies shift the movement of migrants to new landscapes and waterscapes that alter the experience for both people en route and the people they encounter along the way. At the same time, people on the move create their own corridors as new technologies enable the rapid dissemination of local knowledge of the conditions along the route through mobile phones, GPS, and social media. As Gabriel Popescu suggests, 'Digital technologies bring together issues of politics and space in ways that change how power is organized and distributed geographically' (Popescu in Jones et al. 2017: 4).

In addition to the expansion of security practices at borders, many states are externalizing border enforcement through agreements with neighbouring countries. Border externalization means that much of the work of enforcing the border is done by transit states that are not the final destination of people on the move (Casas-Cortes, Cobarrubias, \& Pickles 2013, 2015; Collyer 2007, 2012; Collyer \& King 2015). The United States has deals with Canada and Mexico that push its borders outside of the actual borderline; the European Union has signed deals with Turkey, Morocco, and Afghanistan that enlist these countries to patrol for potential migrants and prevent them from reaching the edges of the EU. The border is no longer located only at the edge of a state; it has become a mobile phenomenon (Jones \& Johnson 2014; Amilhat Szary \& Giraut 2015). The EU's deal with Afghanistan allows it to deport an unlimited number of Afghan asylum seekers - who in 2015 constituted the second largest group in Europe, with 196,170 applications - in exchange for providing aid money to Afghanistan (Rasmussen 2016). According to the UN, among the top seven countries with the largest diasporas, three are from South Asia - namely, India, Bangladesh, and Pakistan with sixteen, seven, and six million people, respectively (United Nations 2015).

\section{Borders in South Asia}

In South Asia, the past decade has been characterized by similarly dramatic changes at borders. India has expanded and reinforced the fences on its borders with Pakistan, Bangladesh, and Myanmar, and currently has more kilometres of border fence than any other country in the world. It also has the largest border security force, with over 200,000 members (Gohain 2015; Horstman \& Cole 2015; McDuie-Ra 2014; Sur 2015b). In 2015, India and 
Bangladesh ratified the long-stalled Land Boundary Agreement that settled border disputes between the two countries and exchanged their border enclaves. Despite the accord, however, India continues to expand its fences on the Bangladesh border and the killing of more than 1000 Bangladeshi civilians by the Indian Border Security Force over the past decade mars the political relationship between the two countries (Human Rights Watch 2010). At the same time, India and Pakistan's standoff over Kashmir remains stalled without an end in sight. Seventy years after the Partition of British India, the borders that were left behind continue to divide people and perpetuate conflict in South Asia.

The borders in South Asia have received increased attention in the past ten years as scholars have moved beyond methodological nationalism to think about cross-border historical and contemporary realities. Rather than treating Bangladesh, India, and Pakistan as finalized and separate containers of each population's social, economic, and political life, scholars such as Willem van Schendel and Ranabir Samaddar have shifted the focus of study to look at cross-border connections (Baud \& van Schendel 1997; Van Schendel 2001, 2002, 2005, 2013, 2015; Samaddar 1999). Following their lead, there has been a series of significant cross-border articles and books focusing on the border enclaves along the India-Bangladesh border, border fencing and security, and migration and refugees (Cons 2012, 2013, 2014, 2016; Gellner 2013; Jones 2009a, 2009b, 2009c, 2012; McDuie-Ra 2012, 2016; Shewly 2013, 2015, 2016; Sanyal 2009; Sur 2013, 2015a; Ferdoush 2014, 2018; Ferdoush \& Jones 2018). These new studies consider the continued impact of partition on South Asian communities and the current lived experiences of border spaces. The new trends are summarized and expanded in a recent special issue of Political Geography, which argues that the legacies of colonialism, partition, violence, and cross-border movement and connections make South Asia a 'particularly productive place to engage questions of borders and margins' (Cons \& Sanyal 2013: 6).

Scholars such as Joya Chatterji, Lucy Chester, Vazira Zamindar, Willem van Schendel, and Jason Cons have each made significant contributions to the research on the aftermath of Partition's borders in South Asia (Chatterji 1994, 2007; Chester 2008, 2013; Zamindar 2007). Collectively, their work considers the arbitrary nature of the borders that have divided South Asia for seventy years and investigates the role these lines continue to play in the politics, economics, and cultural production of South Asia.

At the western India-Pakistan border, there was a rapid movement of people across the new lines just after Partition, but the eastern border saw slower migration as people assessed their situation and, over decades, 
decided to move. Chatterji looks at 'the impact of partition upon the social and political fabric of Bengal and of India' during the twenty years after the event (Chatterji 2007: 4), emphasizing the differences between the post-Partition period in the east and the west of South Asia. On the eastern border, West Bengal's leadership sought to disperse the migrants and prevent them from becoming a strong group. Huge migrant populations during the Bangladesh War of Independence accounted for 15 per cent of the total population and 25 per cent of the population in urban areas in West Bengal in 1973 (Chatterji 2007: 150). Chatterji also considers the post-Partition experience of the Muslims who chose to stay in West Bengal. She suggests that there was some forced assimilation, at least in public posture, and that they began to cluster in particular places - particularly when Muslims left the cities for rural areas near the border with East Pakistan.

Other scholars have considered the boundary commissions' decisionmaking process and the impact of the lines they drew. Chester's work analyses the role of the boundary commissions in the Partition decision and the consequences for the India-Pakistan border (Chester 2008, 2013). Chester argues that the Partition boundaries demonstrate the effort of British colonial leaders to maintain some semblance of control over South Asia even after decolonization. The devastation after the event, according to Chester, was less about the precise location of the line on the map and more about the failure to recognize the large social disruption that the creation of new ideas of homeland and belonging would have.

As the reality of the situation took hold, people across South Asia were faced with the process of imagining a new mental map of their place in the world. Zamindar focuses on the impact that these new ideas of a 'homeland' defined by arbitrary borders had over the ensuing decades (Zamindar 2007). She uses oral histories and first-hand accounts of the impact that the emergence of these new territories had on the lives of people at a local scale to demonstrate that people who were compelled to move across the border, leaving their homes, relatives, and jobs behind, still feel a sense of loss and are in limbo. Many of them would still like to think of the regions divided by the new borders as really part of the same country. Frank Billé considers this feeling of limbo to be 'territorial phantom pains' (2014). By this, Billé means people's perception that a geographic area is (or should be) part of their nation still, even though it no longer is.

The effort to fix the line and then secure it is carried out through the imposition of bureaucratic control, the deployment of paramilitary forces, the homogenization of the borderland population, and the creation of techniques to resolve inter-state conflict (van Schendel 2005: 97). Each of 
these processes has an impact on both the local borderlands and the political centres. Van Schendel equates the making of a border to an earthquake that disrupts the land, and emphasizes that borderlands are a space that calls many assumptions about states, and the entire world political system, into question: 'Global reterritorialization is best approached by looking simultaneously at states, transborder arrangements, and transnational flows because these are complementary arenas of power, profit and imagination' (van Schendel 2005: 385). He notes that at the India-East Pakistan/Bangladesh border there was always substantial violence directed towards borderland people, even during periods of peaceful relations between the states. Further, he argues that the tendency to only see borderlands through the lens of the state dehumanizes the space and erases the local scale of the suffering produced by the line.

Cons extends this point through a case study of the Dahagram-Angorpota enclave on the India-Bangladesh border that contextualizes these sensitive spaces within the broader literature of post-colonial state formation, national imagination, human territoriality and sovereignty (Cons 2016; Sack 1986). In doing so, he argues that sensitive spaces trouble the postcolonial imagination of continuous territory, a clearly demarcated border, and identity and belonging. Elizabeth Dunn and Cons argue that multiple forms of power operate at the same time in these spaces: both the ruled and the rulers work out their own ways to set up the rules of being governed and to govern in their everyday lives (Dunn \& Cons 2014). Consequently, these spaces remain constant sources of anxiety and ambiguity for both those who are governed and those who seek to govern. They unsettle the notion of postcolonial South Asia, which is based on the idea 'that nationality and territory must align' (Cons 2016: 7). In the end, Cons suggests that there is an ambivalence around borders, especially the former border enclaves: 'they are spaces that, to paraphrase Carl Schmitt, the center thinks with intense passion, though not necessarily with great care' (Cons 2016: 21).

This book contributes to this growing literature on borders in South Asia by paying particular attention to how these changes at the border affect people who live in the borderlands. At first, the imposition of the Partition borders was a shock to people who had previously lived in the heartlands of British India. Even for many years after the line was drawn on a map, people on the ground were unaware of exactly where it was - or simply ignored it. However, by the late 1990s, the states increasingly tried to normalize movement through crossing points and prevent unauthorized movements through violence. While most of the borders in South Asia are now clearly demarcated and heavily militarized, this has not been successful 
in stopping the movement of people and goods across them. Drawing on both the formal and informal phenomenon of cross-border mobilities in South Asia, the first section of this volume suggests that no matter how clearly a border is demarcated or how heavily it is militarized, people will continue defying the border as long as it remains a question of kinship, livelihood, structural needs, and, above all, survival.

\section{Mobility, Place, and Belonging in Diaspora}

Beyond South Asia, borders and mobility have received substantial attention from scholars interested in the relationships between people, place, and movement. Tim Cresswell argues that mobility is a fundamental geographical facet of existence and, as such, provides a rich terrain from which narratives - and, indeed, ideologies - can be, and have been, constructed' (Cresswell 2006: 1). Cresswell sees a difference between movement (simply going from here to there) and mobility (which has meaning attached to it) (Cresswell 2006: 25). There is a paradox in the contemporary world, where people are defined by their place of birth, citizenship, and identity, but, at the same time, people and goods are constantly in motion - moving around cities, regions, and the world. The contributions to this volume dwell on this conflicted sense of the identity of people on the move, who are simultaneously defined by their movement as 'migrants' but also forever marked by their place of birth.

Following Yi-Fu Tuan, Cresswell defines a 'place' as a space that has meaning attached to it by humans through naming it and interacting with it in some way (Cresswell 2004: 10; Tuan 1977). Doreen Massey expands this definition by identifying four different aspects of 'place': place as a process, place from outside, place as the centre of multiple identities and histories, and place as an outcome of unique interactions (Massey 1997). First, a place is a process because it is always becoming, always in the process of making and remaking. A place is where lives take different shapes, forms, importance, and meaning every day. For a person who is settling into a new place, place-making becomes a process. Second, a place is not only created by the people living there, but also through how the place is identified and imagined by people living outside of that place. These 'others' have a perception of the place that also plays a role in making the place what it is. For example, for a migrant from South Asia who has never been to the Middle East or Europe, these still remain idealized places. An idea of them has been created by the media, by literature, and by word of mouth that plays a significant role in defining what the Middle 
East or Europe is. The third aspect for Massey is the role a place plays as a centre of multiple identities and histories. A place has its own history and different people connect to each history in different ways, which makes it distinct from other places. People who live in a place identify with that place, but this identification is not universal; people from the same place might identify with that place from a very different perspective. Finally, place is an outcome of unique interactions: a place is created and made unique as a result of the interactions that take place among people, both those living there and those outside. These particular ways of doing things create the sense of place that signifies the difference between an insider who is from there and someone else: an outsider who has not yet achieved local status.

For diasporic populations, the idea of a homeland creates a very particular version of place that is rooted in memory and nostalgia. However, the meaning of the home is also contested, as people possess multiple connections to different places that do not fit neatly into a simple categorical box. According to Robert Kaiser, 'homeland' is a term 'used to symbolize the deep emotional connectedness that people are said to feel towards their place of origin, as well as toward more geographically expansive and socially constructed birth spaces such as national homelands' (Kaiser 2009: 4). Rather than treating these categories as existing realities, the focus for many scholars is on understanding the narratives and practices that produce an idea of home and create and reiterate those feelings of connection to place within a population and for individuals (Mack 1993). There is not a single version of a homeland that ties a particular group to the place, but rather evocations and enactments that produce an idea of home that may provide comfort - or a sense of persistent loss and longing - for a person on the move.

There is a growing literature that delves into the experiences of people from South Asia as they make new lives around the world. Mizanur Rahman and Tan Tai Yong focus on the impact of remittances as wealth flows back to the relatives who remained at home (2015). Nazli Kibria has traced the experiences of Bangladeshi migrants in Britain, the United States, the Middle East, and Malaysia (Kibria 2011). Her work emphasizes the significance of religion for many migrants, who also work to integrate themselves into the economic and social lives of their new homes and thereby become enmeshed in the place. Bald et al. look at the experiences of South Asian people on the move, but emphasize the lens of US imperial power in shaping the process as the larger political forces of the Cold War, the War on Terror, and global capitalism affect 
everyday experiences (2014). Tasneem Siddiqui offers the experiences of the women from Bangladesh who migrate mostly to the Arab states as domestic workers (2001). Gauri Bhattacharya and Susan Schoppelrey focus on the imaginations of South Asian migrants before migrating to North America and their post-immigration experiences. They also emphasize the unrealistic expectations that South Asian migrant parents place on their first-generation immigrant children, which result in substantial stress and anxiety (Bhattacharya \& Schoppelrey 2004). Each of these works highlights migrant communities' complex, conflicted, and dynamic sense of belonging in multiple places.

The chapters of this book illustrate these nuances, while also recognizing that there is something distinctive about the experience of migrating to a new home and navigating the multiple attachments that it produces. The contributors consider how migrants experience lives on the move and how they maintain connections to their ancestral home through literature and collective memory.

\section{Structure of the Book}

This book brings together an interdisciplinary and international group of scholars in the fields of Anthropology, Development Studies, English Literature, Geography, History, Migration Studies, Political Science, Psychology, and Sociology based in Afghanistan, Australia, Bangladesh, Belgium, Croatia, India, Japan, and the United States to answer the overarching question of the book: How do borders and restrictions on mobility affect the lives of people from South Asia and beyond? The chapters investigate borders and migration in South Asia with an emphasis on three themes: experiencing borders in South Asia, migrant lives on the journey to new homes, and diasporic representations of mobility and borders. The contribution of this volume is to add layers of complexity to this story, as the individual experiences of people on the move belie the desire for easy metanarratives to explain a global picture. Instead, the contributors provide multiple snapshots of the situation at the local scale of South Asian borders, at the regional scale of labour migration within South Asia, and at the global scale of migration to Europe and North America.

The first section of the book focuses on the lingering impact of Partition's borders within South Asia by considering how these lines continue to impact the lives of those who live in the borderlands. In Chapter 1, Reece 
Jones investigates the local actions that transgress, subvert, and ignore the imposition of sovereign authority at the borders of sovereign states. To reconcile conflicting views on resistance, this chapter proposes the concept of 'spaces of refusal' to understand a range of activities that are not overt political resistance but nevertheless refuse to abide by the binary enframing of state territorial and identity categories. In Chapter 2, Edward Boyle and Mirza Zulfiqur Rahman draw on fieldwork at cross-border markets along the India-Bangladesh border in Meghalaya and Tripura to examine how the multi-layered infrastructure of border management and governance affects local community interactions and the flow of goods, political processes, and cross-border connectivity. In Chapter 3, Azizul Rasel tells the neglected micro-narrative of the Adivasi Lushai people living in the borderlands of Bangladesh in the Chittagong Hill Tracts, examining how they deal with the border and the increasing surveillance of the Indian and Bangladeshi states in their everyday life.

The second section of the book looks at longer-distance migrations, both within South Asia and to the Middle East and Europe. In Chapter 4, against a backdrop of rapid urbanization and growing internal migration, Kavitha Rajagopalan argues that new forms of cross-border migration, as well as the entrenchment of nationalistic and Islamophobic approaches to citizenship and migration policymaking, are complicating the already complex picture of citizenship and belonging in contemporary South Asia. In Chapter 5 , Ananya Chakraborty draws on case studies of undocumented Bangladeshi women who are engaged in various informal sector occupations in Maharashtra to highlight the multiple vulnerabilities and threats that they face, not only due to their status as undocumented migrants, but because of their gender positioning in the informal labour market. In Chapter 6, Andrea Wright uses ethnographic and archival research conducted in the United Arab Emirates and India to illustrate how the Indian government developed and implemented emigration policies that viewed women as 'vulnerable subjects' at risk of trafficking. In Chapter 7, James Weir and Rohullah Amin recount the harrowing story of Akbar, a young Afghan man who set out on foot from Kabul to try to reach Frankfurt with millions of other people on the move in the summer of 2015. This first-person account of one migrant's journey helps to humanize the confusing and overwhelming story of the global migration crisis. In Chapter 8, Marta Zorko provides an overview of how the militarization, securitization, and hardening of borders in Europe affect migrants from South Asia. 
The third section of the book considers South Asian diasporic experiences in Africa, Europe, and Fiji through literature and historical memory. In Chapter 9, Malini Sur and Masja van Meeteren draw on the experience of Bangladeshi men who have migrated to Belgium to argue that integration should be conceptualized not as the outcome of ideal type national models of citizenship and integration, but as the product of the intersection of migrant aspirations and strategies within regulatory frameworks. In Chapter 10, Riddhi Shah argues that, despite hundreds of years of movement between East Africa and India through the Indian Ocean, histories of slavery are conspicuous in their absence in Indian and Gujarati collective memories. The chapter analyses Gunvantrai Poptabhai Acharya's novel Dariyalal, which illustrates the lingering impact of migration and diaspora in the region. In Chapter 11, Tana Trivedi focuses on the work of Sudesh Mishra, a contemporary Fijian-Indian-Australian poet who addresses the idea of the fragmented diasporic identities of Indo-Fijians and the inability to locate a 'home' amidst borders of history, memories, and transnational identities. This chapter brings to fore the sense of fragmentation and dislocation that mark the lives of Indo-Fijians and demonstrates that Mishra is a transnational poet whose work proves that home is a contested space in Fiji.

\section{A Point of Departure}

In the end, the dozens of Bangladeshis selling Chinese-made selfie sticks to tourists from the United States and Japan at the Colosseum, an ancient ruin of the Roman Empire located in Italy, illustrates the reality of borders and mobility in the twenty-first century. Things are clearly changing. People move to new places, create new cultural ideas, establish new networks and alliances, and challenge the fixity of the state and its borders. However, the past still matters: people maintain connections, albeit sometimes tenuous, to their previous homes, families, and belief systems. The borders and states that divide up territories and protect privileges deeply shape the experiences of people on the move. The history of what was once there is still important, even as new people and new technologies change what the relationships between people, places, and the world around us will look like in the future. The chapters of this book delve into the relationships between fixity and movement, continuity and change, and the past and the future as they unravel the complex interplay between borders and mobility in South Asia and beyond. 


\section{References}

Amilhat Szary, A.-L. and Giraut, F. (2015) Borderities and the Politics of Contemporary Mobile Borders. London: Palgrave Macmillan.

Bald, V., Chatterji, M., Reddy, S., and Vimalassery, M., eds. (2013). The Sun Never Sets: South Asian Migrants in an Age of U.S. Power. New York, NY: New York University Press.

Baud, M. and van Schendel, W. (1997). Towards a comparative history of borderlands. Journal of World History, 8, pp. 211-242.

Bhattacharya, G. and Schoppelrey, S.L. (2004). Preimmigration beliefs of life success, postimmigration experiences, and acculturative stress: South Asian immigrants in the United States. Journal of Immigrant Health, 6(2), pp. 83-92.

Billé, F. (2014). Territorial phantom pains (and other cartographic anxieties). Environment and Planning D: Society and Space, 32(1), pp. 163-178.

Blangiardo, G. (2009). Foreigner's presence in Italy: From a reference framework to future development scenarios. In: V. Cesareo, ed., The Fifteenth Italian Report on Migrations. Polimetrica: Milan, pp. 33-55

Casas-Cortes, M., Cobarrubias, S., and Pickles, J. (2013). Re-bordering the neighbourhood: Europe's emerging geographies of non-accession integration. European Urban and Regional Studies, 20(1), pp. 37-58.

Casas-Cortes, M., Cobarrubias, S., and Pickles, J. (2015). Riding routes and itinerant borders: Autonomy of migration and border externalization. Antipode.47(4), pp. 894-914.

Chatterji, J. (1994). Bengal Divided: Hindu Communalism and Partition, 1932-1947. Cambridge: Cambridge University Press.

Chatterji, J. (2007). The Spoils of Partition: Bengal and India 1947-1967. Cambridge: Cambridge University Press.

Chester, L. (2008). Boundary commissions as tools to safeguard British interests at the end of empire. Journal of Historical Geography, 34, pp. 494-515.

Chester, L. (2013). Borders and Conflict in South Asia: The Radcliffe Boundary Commission and the Partition of Punjab. Manchester: Manchester University Press.

Collyer, M. (2007). In-between places: Trans-Saharan transit migrants in Morocco and the fragmented journey to Europe. Antipode, 39(4), pp. 668-90.

Collyer, M. (2012). Migrants as strategic actors in the European Union's global approach to migration and mobility. Global Networks, 12 (4), pp. 505-24.

Collyer, M. and King, R. (2015). Producing transnational space: International migration and the extra-territorial reach of state power. Progress in Human Geography, 39(2), pp. 185-204.

Cons, J. (2012). Histories of belonging(s): Narrating territory, possession, and dispossession at the India-Bangladesh border. Modern Asian Studies, 46, pp. 527-558. 
Cons, J. (2013). Narrating boundaries: Framing and contesting suffering, community, and belonging along the India Bangladesh border. Political Geography, 35, pp. 37-46.

Cons, J. (2014). A View from the India-Bangladesh border. East Asia Forum, 8 April Available http://www.eastasiaforum.org/2014/04/o8/a-view-fromthe-india-bangladesh-border/

Cons, J. (2016). Sensitive Space: Fragmented Territory at the India-Bangladesh Border. Seattle: University of Washington Press.

Cons, J. and Sanyal, R. (2013). Geographies at the margin: Borders in South Asia- an introduction. Political Geography, 35, pp. 5-13.

Cresswell, T. (2004). Place: An Introduction. New Jersey: Jon Wiley and Sons.

Cresswell, T. (2006). On the Move: Mobility in the Modern Western World. London: Taylor and Francis.

Dearden, L. (2017). Bangladesh is now the single biggest country of origin for refugees on boats as new route to Europe emerges. The Independent. 05 May. http://www. independent.co.uk/news/world/europe/refugee-crisis-migrants-bangladeshlibya-italy-numbers-smuggling-dhaka-dubai-turkey-detained-a7713911.html

Dunn, E. and Cons, J. (2014). Aleatory sovereignty and the rule of sensitive spaces. Antipode, 46(1), pp. 92-109.

Ferdoush, M.A. (2013). Rethinking border crossing narratives: A comparison between Bangladesh-India enclaves. Journal of South Asian Studies, 2(2), pp. 107-113.

Ferdoush, M.A. (2018). Seeing borders through the lens of structuration: A theoretical framework. Geopolitics, 23 (1), pp. 180-20o. https://doi.org/10.1080/14650045.20 17.1341406

Ferdoush, M.A. and Jones, R. (2018). The decision to move: Post-exchange experiences in the former Bangladesh-India border enclaves. In: A. Horstmann, M. Saxer, and A. Rippa, eds., Routledge Handbook of Asian Borderlands. London: Routledge, pp. 255-265.

Gellner, D., ed. (2013). Borderland Lives in Northern South Asia. Durham, NC: Duke University Press.

Gohain, S. (2015). Militarized borderlands in Asia. IIAS Newsletter, 71, pp. 21-35.

Horstmann, A. and Cole, T. (2015). State violence, state building. IIAS Newsletter, 71, pp. 24-25.

Human Rights Watch (2010). Trigger Happy: Excessive Use of Force by Indian Troops at the Bangladesh Border. New York: Human Rights Watch.

Johnson, C., Jones, R., Paasi, A., Amoore, L., Mountz, A., Salter, M., and Rumford, C. (2011). Interventions on rethinking 'the border' in border studies. Political Geography, 30(2), pp. 61-69.

Jones, R. (2009a). Geopolitical boundary narratives, the global war on terror and border fencing in India. Transactions of the Institute of British Geographers, 34, pp. 290-304. 
Jones, R. (2009b). Agents of exception: border security and the marginalization of Muslims in India. Environment and Planning D: Society and Space, 27, pp. 879-897. Jones, R. (2009c). Sovereignty and statelessness in the border enclaves of India and Bangladesh. Political Geography, 28(6), pp. 373-381.

Jones, R. (2012). Border Walls: Security and the War on Terror in the United States, India, and Israel. London: Zed Books.

Jones, R. (2016). Violent Borders: Refugees and the Right to Move. New York: Verso. Jones, R. and Johnson, C. (2014). Placing the Border in Everyday Life. New York: Routledge.

Jones, R. and Johnson, C. (2016). Border militarization and the rearticulation of sovereignty. Transactions of the Institute of British Geographers, 41, pp. 187-200.

Jones, R., Johnson, C., Brown, W., Popescu, G., Pallister-Wilkins, P., Mountz, A., and Gilbert, E. (2017). Interventions on the state of sovereignty at the border. Political Geography, 59, pp. 1-10.

Kaiser, R. (2009). Fatherland/homeland. The International Encyclopedia of Human Geography. London: Elsevier.

Kibria, N. (2011). Muslims in Motion: Islam and National Identity in the Bangladeshi Diaspora. New Brunswick, NJ: Rutgers University Press.

Mack, A., ed. (1993). Home: A Place in the World. New York: New York University Press.

Massey, D. (1997). A global sense of place. In: T. Burns and D. Gregory, eds., Reading Human Geography. London: Arnold, pp. 315-323.

McDuie-Ra, D. (2012). Tribals, migrants and insurgents: Security and insecurity along the India-Bangladesh border. Global Change, Peace \& Security, 24(1), pp. 165-182.

McDuie-Ra, D. (2014). The India-Bangladesh border fence: Narratives and political possibilities. Journal of Borderlands Studies, 29, pp. 81-94.

McDuie-Ra, D. (2016). Borderland City in New India: Frontier to Gateway. Amsterdam: Amsterdam University Press.

Parker, N. and Williams, V. (2009). Lines in the sand? Towards an agenda for critical border studies. Geopolitics, 14(3), pp. 582-587.

Rahman, M. and Kabir, A. (2012). Moving to Europe: Bangladeshi migration to Italy. ISAS Working Papers. Institute of South Asian Studies, National University of Singapore. Available https:/www.flles.ethz.ch/isn/137192/ ISAS_Working_Paper_142_-_email_-_Moving_to_Europe_-_Bangladesh_Migration_to_Italy_07022012143721.pdf

Rahman, Md. M. and Yong, T.T. (2015). International Migration and Development in South Asia. London, UK: Routledge.

Rasmussen, S. (2016). EU signs deal to deport unlimited numbers of Afghan asylum seekers. The Guardian. 03 October. https://www.theguardian.com/globaldevelopment/2016/oct/o3/eu-european-union-signs-deal-deport-unlimitednumbers-afghan-asylum-seekers-afghanistan 
Sack, R. (1986). Human Territoriality: Its Theory and History. Cambridge: Cambridge University Press.

Samaddar, R. (1999). The Marginal Nation: Transborder Migration from Bangladesh to West Bengal. Dhaka: The University Press Limited.

Sanyal, R. (2009). Contesting refugeehood: Squatting as survival in post-partition Calcutta. Social Identities, 15 , pp. 67-84.

Shewly, H.J. (2013). Abandoned spaces and bare life in the enclaves of the IndiaBangladesh border. Political Geography, 32, pp. 23-31.

Shewly, H.J. (2015). Citizenship, abandonment and resistance in the India-Bangladesh borderland. Geoforum, 67, pp.14-23. https://doi.org/10.1016/j.geoforum.2015.10.008 Shewly, H.J. (2016). Survival mobilities: Tactics, legality and mobility of undocumented borderland citizens in India and Bangladesh. Mobilities, 11(3), pp. 464-484.

Siddiqui, T. (2001). Transcending Boundaries: Labour Migration of Women from Bangladesh. Dhaka: The University Press Limited.

Sur, M. (2013). Bamboo baskets and barricades: Gendered landscapes at the India-Bangladesh border. In: B. Kalir and M. Sur, eds., Transnational Flows and Permissive Polities: Ethnographies of Human Mobilities in Asia. Amsterdam: IIAS Publications, pp. 127-150.

Sur, M. (2015a). Indelible lines: Revisiting borders and partitions in modern South Asia. Mobility in History, 6(1), pp. 70-78.

Sur, M. (2015b). Spectacles of militarization. IIAS Newsletter, 71, pp. 28-29.

Tuan, Y. (1977). Space and Place: The Perspective of Experience. Minneapolis: University of Minnesota Press.

United Nations High Commissioner for Refugees (2016). Serbia Update, December 12-14. Available https://reliefweb.int/report/serbia/unhcr-serbia-update12-14-december-2016

United Nations (2015). International Migration Report. New York: United Nations. Vallet, E. (2014). Borders, Fences, and Walls: States of Insecurity? London: Routledge. van Schendel, W. (2001). Who speaks for the nation? Nationalist rhetoric and the challenge of cultural pluralism in Bangladesh. In: W. van Schendel and E. Zürcher, eds., Identity Politics in Central Asia and the Muslim World:Nationalism, Ethnicity, and Labour in the Twentieth Century. New York: I.B. Tauris Publishers, pp. 107-147. van Schendel, W. (2002). Stateless in South Asia: The making of the India-Bangladesh enclaves. The Journal of Asian Studies, 61, pp. 115-147.

van Schendel, W. (2005). The Bengal Borderland: Beyond State and Nation in South Asia. London: Anthem Press.

van Schendel, W. (2013). Making the most of 'sensitive' borders. In: D. Gellner, ed., Borderland lives in northern South Asia. London: Duke University Press, pp. 266-272. 
van Schendel, W. (2015). A war within a war: Mizo rebels and the Bangladesh

liberation struggle. Modern Asian Studies, pp. 1-43.

Zamindar, V. (2007). The Long Partition and the Making of Modern South Asia:

Refugees, Boundaries, Histories. New York: Columbia University Press.

\section{About the Authors}

Reece Jones is a Professor of Geography and Environment at the University of Hawai'i at Mānoa. He is the author of two books, Border Walls: Security and the War on Terror in the United States, India and Israel (2012, Zed Books) and Violent Borders: Refugees and the Right to Move (2016, Verso). He also edited Placing the Border in Everyday Life with Corey Johnson (2014, Routledge Border Regions Series) and Open Borders: In Defense of Free Movement (2018, University of Georgia Press).

Md. Azmeary Ferdoush is a Lecturer in Sociology at the University of Dhaka, Bangladesh and a Ph.D. candidate in Geography and Environment at the University of Hawai'i at Mānoa. He is an East West Centre Graduate Degree Fellow. His research interests include, but are not limited to, borders and enclaves with a focus on Bangladesh and India, social theory, political geography, (non)citizenship, state, and migration. He has published several peer reviewed journal articles and book chapters on borders and enclaves, and his op-eds have been featured in the Daily Star and the Dhaka Tribune. 


\section{Section I}

Experiencing Borders in South Asia 



\title{
$1 \quad$ Spaces of Refusal
}

\author{
Rethinking Sovereign Power and Resistance at the Border ${ }^{1}$ \\ Reece Jones
}

Jones, Reece and Ferdoush, Md. Azmeary (eds), Borders and Mobility in South Asia and Beyond. Amsterdam: Amsterdam University Press, 2018 DOI: 10.5117/9789462984547/CHO1

\begin{abstract}
This chapter investigates the local actions that transgress, subvert, and ignore the imposition of sovereign authority at the borders of sovereign states. Drawing on interviews with borderland residents, it analyses how people interact with, talk about, and cross the border in their daily lives. The motives and consequences of these cross-border connections are not adequately captured by the literature on sovereign power and the state of exception, which identifies very little space for resistance, or the literature on dominance-resistance in power relations, which understands most actions as political resistance in a broad milieu of power. To reconcile these conflicting views on resistance, this chapter proposes the concept of spaces of refusal to understand a range of activities that are not overt political resistance but nevertheless refuse to abide by the binary enframing of state territorial and identity categories.
\end{abstract}

Keywords: India, Bangladesh, borders, resistance, refusal, identity

\section{Cross-Border Movement}

Moushumi, a servant in a wealthy Bangladeshi family's home, set out for India in the late afternoon to visit her son. ${ }^{2}$ She packed a small bag

1 This chapter originally appeared in the Annals of the Association of American Geographers (2012) 102(3): 685-699. It is reprinted with permission.

2 Moushumi is a pseudonym. All interviews for this project were conducted anonymously, except for those with elected public officials. The research described in this chapter is based on 101 in-depth interviews and fifteen focus groups conducted in Bangladesh and the Indian state of West Bengal. The interviews were conducted in Bengali, except where indicated [in English], and translated by the author in collaboration with a research assistant in Bangladesh. Through 
with a change of clothes and two shingara - Bengali-style samosas, more rounded than angular, with a savoury potato filling. She met her 'uncle', the broker, outside his house and gave him 200 Bangladeshi Taka, about US\$3. Six other travellers arrived as they waited for darkness to fall. She dozed on the floor and ate a shingara. A few hours later they walked to the edge of the river, hopped in a small boat, and floated for a few minutes - definitely less than ten - until the boatman pulled the boat back to the bank of the river. The travellers got out and climbed onto the waiting flatbed rickshaw for the ride into a nearby Indian village. She rested at a relative's house that night and then continued her journey to her son's house the next morning. She stayed there for about a month, cooking for her son and playing with her grandchildren, and then made the return trip to the Indian village near the border. She paid the Indian broker, this time in Rupees, waited for nightfall, and got back in the same boat. The return trip took slightly longer because it was against the current, but she was back at the broker's house in Bangladesh by midnight. She set out early the next morning and was back to work at the wealthy family's house by noon. She never saw any border guards, or even the new border fence, but they were certainly there somewhere in the darkness on the banks of the river. The only difference from her previous trips to visit her son was the extra cost of paying the brokers, but she enjoyed the ride in the boat, which was more pleasant than just walking across the border, as she had always done before.

How should theorists of state sovereignty, transnationalism, and resistance conceptualize the experiences of Moushumi - and thousands of other people like her - who, when faced with what they perceive to be a cumbersome and arbitrary rule of the state, refuse to submit to the imposed territorial order and instead continue to live their normal lives? Is she merely a 6o-year-old woman who decided to make the short trip to visit her son and grandson without regard for its political implications? Prior to 1947, it would have been an unremarkable trip within a single colonial space. Even for many years after 1947, when the new sovereign states officially drew a line between her village and her son's, movement continued without much intervention from the authorities. Or should she be considered a criminal because she violated the laws of both India and Bangladesh? Is she merely a poor, illiterate woman who does not understand the concept of state 
sovereignty? Or is she part of the resistance that contests the borders that divide the world into territorially defined, sovereign states? Should we interpret these everyday transgressions, when people simply ignore a distant rule that does not seem to apply to them, as acts of defiant resistance? Do these movements threaten the authority of the state? Or is it a minor flow that can be allowed across a leaky border?

Neither the literature on sovereign power and the state of exception nor that on dominance and resistance in power relations precisely captures the motives and consequences of Moushumi's trip. The burgeoning literature on the state of exception identifies very little space for resistance (Agamben 1998, 2005; Edkins \& Pin-Fat 2004; Minca 2007). In this framework, the worldwide expansion of the state system has resulted in an all-encompassing, unitary, and increasingly globalized sovereign power (Dillon 2004). The sovereign gains authority not simply by establishing and enforcing laws within a territory, but specifically through the deployment of the state of exception: a time/space where others must follow the laws, but the sovereign can operate outside of the legal system if it perceives a threat to its authority (Agamben 1998, 2005). Jenny Edkins and Veronique Pin-Fat argue that this theorization of sovereign power precludes the possibility of meaningful resistance because any perceived threat can be neutralized through the use of the exception, a time/space where power relations are replaced by violence relations. In this frightening scenario, the political citizen with rights protected by laws is evanescent and, as Edkins and Pin-Fat put it, '[w]e have all become homines sacri or bare life in the face of a biopolitics that technologizes, administers, and depoliticizes, and thereby renders the political and power relations irrelevant' (2004: 9). In this view, Moushumi's trip would not be resistance at all; rather, it is an activity that is currently allowed and monitored by the border guards, but that could quickly be violently suppressed if necessary.

While the state of exception literature finds little space for resistance, the literature on dominance and resistance in power relations sees virtually every action within the framework of power (Scott 1985; Sharp et al. 2000). Power often appears to be pervasive: every action is political and is made by either a dominating or resisting agent in the broad milieu of power relations (Rose 2002). The best known example is James C. Scott's argument that even when full-fledged revolution is impossible, people continue to use all the avenues available to them to resist undesired changes to their lives: 'Foot dragging, dissimulation, desertion, false compliance, pilfering, feigned ignorance, slander, arson, sabotage, and so on [...] They require little or no coordination or planning; the make use of implicit understandings 
and informal networks; they often represent a form of individual self-help; they typically avoid any direct symbolic confrontation with authority' (Scott 1985: xvi). In Scott's formulation, almost any type of noncompliance is considered resistance. His point is that simply refusing to go along with a new regime of land ownership or resource management represents a dismissal of the imposed order and a way of continuing to practice alternative ways of living. In geography, Jo Sharp et al. have proposed an equally capacious definition of resistance as any activity that 'attempts to set up situations, groupings, and actions which resist the impositions of dominating power' ranging from 'breaking wind when the king goes by' to 'violent actions' with transformative goals (Sharp et al. 2000: 3). In the dominance-resistance framework, Moushumi's trip would certainly be an example of resistance to the authority of the state.

To reconcile these two sets of literature with starkly different views of power and resistance, this chapter makes three arguments about the state, sovereignty, and cross-border movement. First, it demonstrates that scholars of the state of exception profoundly overestimate the extent and homogeneity of state authority. Rather than understanding sovereign power as unitary and all encompassing, it is better conceptualized as multifaceted, partial, and conflicted (Jones 2009b). Despite the expansion of the sovereign state over the past century, there are many loosely administered places where the authority of the state is weak or non-existent. Exceptional violence periodically materializes in these spaces, but is not as pervasive as the term 'state of exception' implies. Even at the border, where the performances of sovereign authority are often the most conspicuous, the territorial control of sovereign power is incomplete. Indeed, the overt performances and need for exceptional violence are indicative of its weakness; they would be unnecessary if it had firm control. The second and third sections of this chapter demonstrate this claim by examining the literature on state-making in marginal areas, describing the fitful expansion of the Bangladeshi and Indian states at the border, and analysing the current practices of the border guards. These officials - whom Judith Butler calls the 'petty sovereigns' of governmentality - are delegated the authority to make the decision about the exception for the sovereign; however, at the India-Bangladesh border, they use this authority to allow themselves to operate outside the laws of the state, often undermining the state's goals of regulation, legibility, and order (Butler 2004: 56).

Second, this chapter questions the dominance-resistance binary that defines all activities as political. Instead, it looks for alternative ways to understand a variety of actions that are more concerned with simply getting by 
or avoiding adverse changes to daily life. If everything is understood as part of the interplay of dominance and resistance in power relations, the analysis becomes increasingly meaningless because it fails to consider whether the resistance actually produces any changes to the power relationship or if it was even intentional - a decision that is often left to the researcher, not the individual (Pile \& Keith 1997; Rose 2002; Sparke 2008). Cindi Katz proposes an alternative framework that distinguishes between full-fledged resistance - active contestation that attempts to produce emancipatory change - and other quotidian activities that are in relation to power but not overtly contesting it, which she classifies as reworking and resilience in power relations (Katz 2004; Sparke 2008). 'Reworking' refers to actions that alter the organization but not the polarization of power relations. When power relations are reworked, some aspects are improved but the overall situation remains unchanged, as individuals and institutions retain their authority over others. Katz uses 'resilience' to understand actions that enable people to survive without really changing the circumstances that make survival so hard. The fourth section of this chapter analyses theories of resistance and argues for a more nuanced approach to contesting power in both the state of exception and dominance-resistance literatures, emphasizing the process of 'enframing' through which the categories and boundaries of sovereign power are instituted (Mitchell 1990).

Finally, this chapter proposes the alternative of 'spaces of refusal' to conceptualize everyday actions like Moushumi's that disregard the rules of the state in not-completely-administered spaces, but that are not a politically motivated resistance to sovereignty. A space of refusal is a zone of contact where sovereign state practices interact with alternative ways of seeing, knowing, and being. In these spaces, people adopt various means to avoid the sovereignty regime of the state, even when the traditional response of flight is not available (Agnew 2005; Scott 2009). These include evading the state apparatus by not paying taxes, transgressing the state's authority by engaging in activities that are prohibited by the state, and refusing to accept the lines and categories drawn by the state to create and practice its power. Spaces of refusal are not zones where there is a revolution against the state, nor are they spaces of romanticized resistance. Instead, they are characterized by a simple dismissal of the state's claim to define subjects and activities in those spaces (Sharpe et al. 2000; Sparke 2008). The fifth section of this chapter demonstrates how border residents have developed a multitude of strategies that acquiesce to, co-opt, transgress, and ignore both the sovereignty of the state and the violence regime of the border guards. By refusing to accept the binary enframing of the state that attempts to create 
a world of us/them, here/there, and dominance/resistance, Moushumi and many others maintain imaginative geographies outside state-sanctioned categories of identity and territory. These acts of refusal disrupt the ordering logic on which the state relies and maintain the possibility that different frameworks outside of sovereign state territoriality may be created, even while those alternatives are not yet being pursued.

\section{Creating State Spaces and Subjects}

The sovereign state system is based on the idea that the entire territory of the world is divided up into separate spaces, which each have a distinct sovereign government that makes and enforces laws in that territory (Agnew \& Corbridge 1995; Murphy 1996, 2005). The idea of bounded, territorially defined sovereignty was institutionalized in Europe in the modern era and spread through the world via colonization. In terms of state control of territory, Scott argues that human history could be divided into four very simplified eras: ' 1 ) a stateless era (by far the longest), 2) an era of small-scale states encircled by vast and easily reached stateless peripheries, 3) a period in which such peripheries are shrunken and beleaguered by the expansion of state power, and finally, 4) an era in which virtually the entire globe is "administered space" and the periphery is not much more than a folkloric remnant' (Scott 2009: 324). By tracing the ebb and flow of state-making in Southeast Asia, Scott argues that the peripheries at the edges of expanding states were not barbaric places that had never experienced organized society. Instead, he demonstrates that these upland areas were populated by people who had fled the rule of the state because of slavery, conscription, or land co-optation. The spaces outside the state's authority were zones of escape where:

This pattern of state-making and state-unmaking produced, over time, a periphery that was composed as much of refugees as of people who had never been state subjects [... They went] there to evade the manifold afflictions of state-making projects in the valleys. Far from being left behind' by the progress of civilization in the valleys, they have, over long periods of time, chosen to place themselves out of reach of the state. (Scott 2009: 7, 24)

Scott's story disputes the traditional histories of state-making, at least as told by historians of the state, which ignore the possibility of desirable 
statelessness and instead always describe the other on the outside as barbaric, uncivilized, and in need of incorporation into the state.

Scott also questions the claim that states have controlled large territories for most of written history. Instead, he contends, 'To an eye not yet hypnotized by archeological remains and state-centric histories, the landscape would have seemed virtually all periphery and no centers. Nearly all the population and territory were outside their ambit' (Scott 2009:5). His book on stateless spaces reads like an elegy, however, because he concludes that these peripheral spaces outside the sovereign state system are now almost completely gone. He suggests that since the 1950s the deployment of technologies that produce time-space compression has allowed marginal spaces to be incorporated into the state.

This chapter demonstrates that this is not quite the case. Undoubtedly, sovereign states now claim all of the territory of the world and state administration has reached even the most remote places that had previously served as zones of escape from the state. In this sense, the refuges of completely unadministered space that Scott describes are mostly gone today. Despite maps that indicate the contrary, however, many places remain only loosely under the authority of the state. While a state may make the claim of absolute control and be present in most spaces to some degree, some people's lives are only partially affected by it.

Contemporary political maps represent the land of the world as homogenous territories with sharp divisions between them, but the vast majority of the world's population did not live in an independent sovereign state until very recently, after the period of decolonization following World War II. For most places and people in the world, the notion of territorial sovereignty is not old and essential, but new and not wholly familiar. In most cases, the colonial powers demolished the previous political systems and replaced them with colonial governments in territories defined by European imperial claims, not historical linguistic, cultural, economic, or political systems. At the time of decolonization, the only viable option was to maintain the borders of the European colonies as the borders of the new sovereign states; previous political systems had been dismantled, and redrawing borders based on language or ethnicity would be messy and contentious.

In the few cases when borders were redrawn, as with the borders that divide contemporary South Asia near Moushumi's house, economic or cultural patterns of connection and circulation were rarely considered. Instead, British India was partitioned based on the notion that the categories Hindu and Muslim defined the 'nations' of South Asia and that therefore each should have its own sovereign state (Chatterji 1994, 2007). In the former 
province of Bengal, the history of syncretistic and blurred religious practices was ignored (Roy 1984). The economic circuits between jute farms in rural eastern Bengal and the mills and port of Calcutta were not considered. The linguistic and cultural similarities that would exist across the new border were elided. Instead, a line was drawn on a map straight through the former province of Bengal.

And yet, even that supreme act of division produced as many connections as discontinuities. On the one hand, millions of people did eventually move across the new line to join the country of their co-religionists (Chatterji 2007). In Bengal, this movement was much slower than the rapid rush over the western border between India and Pakistan. People found new homes across the border over the next thirty years, a process that sorted the population along religious lines in ways that had never before existed, partially bringing the imagined religious divisions into being. On the other hand, large minority populations (25 per cent Muslim in West Bengal and 11 per cent Hindu in Bangladesh) remain. In an interview, a 64-year-old politician in India explained these connections: 'The people here came from there and the people there came from here, so there is that connection. Those people who live near the border have a cordial relationship. They are invited over to our houses; we are invited to their houses. So in term of this, the relationship is very good. There is not any bad in it.' These movements across the border also had the effect of linking families, like Moushumi's and most families in Bengal, to both countries on both sides of the border (Ghosh 2002).

In the years after partition, the two states slowly and unevenly imposed their sovereignty in the borderlands (van Schendel 2005). The sovereign authority of the state did not immediately come into being in 1947 with the drawing of a map, nor in $195^{2}$ with the marking and surveying of the border, nor in the 1960 s with the creation of border security forces. In practice, despite these attempts to bring the border into being, the borderlands functioned as they had before, with people crossing without consequence for many decades after Partition. With extended families in both countries, many people made trips to visit relatives on the other side. People would also cross the border to go to work, attend festivals, participate in weddings, and even simply to go to the market. The different regulatory and monetary systems on either side of the border also created new economic connections through smuggling networks that solidified business relationships. A 47-year-old teacher in Bangladesh explained how the border operated in the years after Partition: 'My father and grandfather would tell us stories about going to the doctor in the Hindu village across the border and the BDR [Bangladesh Rifles, now Border Guard Bangladesh] and BSF [Indian Border 
Security Force] would not say anything. They did not even bother to come near them. At that time, that was the normal situation.' This freedom of movement could not last forever. The expansion of the sovereign state system occurred with the simultaneous creation of sedentary populations that farm the land and provide bodies for conscription and locatable resources for taxation (Scott 2009).

People who move disrupt the clean, territorially based identity categories of the state by evading state surveillance systems and by creating alternative networks of connection outside state territoriality (Torpey 2000). The creation of the passport and visa system, for example, is a method of monopolizing the capacity to authorize legitimate movement while unambiguously defining national identity categories. Most nation-states base their claims to sovereignty on the notion that their people, however defined, have always lived in that particular place. The erasure of historical movements supports this system and hides the connections between colonialism and the contemporary sovereign state by reframing the current state as a continuation of a historical political entity, not the European colony (Sharma \& Wright 2008).

The most recent and substantial attempt to regulate movement in the Bengal borderlands is the border fence, road, and floodlighting project of the Indian government, which has resulted in the fencing of approximately three quarters of the 4096-km border (Kabir 2005; Ministry of Home Affairs 2008; Jones 2009a, 2009b). As Moushumi's story indicates, and as more interviews will describe below, the advances of the state into the borderlands have not prevented movement across the border, but rather have regulated and channelled it, often through government officials who use their authority for personal gain.

Although the organizing authority of the state was initially weak and slow to arrive in the borderlands, both states worked hard to establish their legitimacy within their territories, a process that became particularly important after Bangladesh's independence in 1971. Both countries had populations that spoke Bengali and had similar cultural histories, which raised questions about the legitimacy of their claims to parts of the former province of Bengal. The result was intensive government efforts to define separate identity categories, justify their claim to authority over those territories, and emphasize the differences between the two places. This was done by not only drawing lines on the ground, but also by creating boundaries between people.

In a speech in 1978, the President of Bangladesh, Ziaur Rahman, outlined the differences between a Bangladeshi and a Bengali: 
Bangladeshi nationalism means we are Bangladeshi. We have a different history. Our country has been born through a different process. Our traditions and culture are different. Our language is different, we are moulding it in our own way - we are modernizing it. We have different prose and poetry; we have different arts and thoughts. Our geographical position is different, our rivers and soils are different. Our people are different. [...] [T] oday a consciousness has grown among our people, which is different from that of the people of our neighbouring country. (Quoted in Huq 1984: 58)

To solidify these distinctions, successive governments have altered the constitution of Bangladesh to define the subjects of the state as Bangladeshi, not Bengali (Murshid 1997, 2001). A 48-year-old teacher in Bangladesh explained the difference thus: 'It is in our constitution. We started our independence movement as Bengalis, with our Bengali language. We say we are Bengali because of that. At the middle of the road, our political situation changed. At that time, those who were administrators, they changed the constitution to say that we are Bangladeshi not Bengali.'

In India, the state also began to define the population by issuing identification cards for rations at state-sponsored shops. This process had the effect of defining the distinction between legal residents of West Bengal - essentially those who were there when the cards were given - and those who came after, who were classified by the state as illegal immigrants from Bangladesh. The distinctions between the two places have been further reified in recent years as terrorism has become a threat in India. In the popular discourse in India, the people and territory of Bangladesh have been increasingly described as a premodern threat to the stability of Indian civil society (Jones 2009a).

Both India and Bangladesh have attempted to impose their authority in the marginal spaces of the borderlands by drawing lines on the ground and in the popular imagination, but the top-down imposition of identities and homeland narratives is not always accepted by people in their everyday lives (Edensor 2002). Some may acquiesce and accept the new order when the political situation changes and administrators dictate it, as the 48-year-old teacher suggests. Others may actively fight a system imposed from above. But many people do neither: they live with the system, but do not necessarily accept it.

\section{Multiple, Fragmented, and Partial Sovereign Power}

As Scott suggests, the last 60 years do represent the first period in human history when this process of making state spaces has been actualized, 
to varying extents, on a global scale. Independent sovereign states can legitimately claim to have some form of control over the vast majority of the territory in the world. In theory at least, almost everyone is subject to the administrative and legal system of a particular sovereign state. This situation has led some scholars to suggest that the spread of sovereign states has resulted in the replacement of power relations - where resistance can occur - with violence relations that leave no space to contest sovereign authority (Edkins \& Pin-Fat 2004). This section briefly reviews the literature on sovereign power by describing the use of the state of emergency by states. Then it argues for a more nuanced view that disaggregates sovereign power from the sovereign state by analysing the conflicted practices of the agents of the state in the borderlands.

In recent years, much of the research on sovereignty has explored Giorgio Agamben's work on the state of exception (Agamben 1998, 2005). Agamben draws on Carl Schmitt to argue that the power of sovereignty comes from not just being able to make and enforce laws in a defined territory, but specifically from being able to decide when those laws can be suspended (Schmitt 1996). The legal systems of all sovereign states include a provision of some kind that allows the declaration of a state of emergency when there is an imminent threat to the continued existence of the state (Hussain 2003; Neocleous 2008). In a state of emergency, the laws of the state remain in place and most people are still required to follow them; however, the sovereign itself is able to operate aggressively both inside and outside of the legal system simultaneously to impose order and authority. States of emergency were originally intended for military threats posed by invading armies, but have increasingly been used in other situations, such as periods of labour unrest, economic crisis, or environmental disaster. Mark Neocleous argues that the declaration of an emergency is not a rare event, but rather a normal part of the practice of sovereignty in the modern era. In a state of emergency, the sovereign can use violence without consequences whenever it perceives its authority to be threatened, which leaves very little space for resistance (Calarco \& DeCaroli 2007; Martinot 2001; Neocleous 2008). Even when there is not a declaration of emergency and the internal practices of a state can be questioned and reworked, the fundamental concept of sovereignty cannot be contested. If it is, the sovereign can declare an emergency and use exceptional violence to enforce its authority (Vacarme 2004; DeCaroli 2007).

Scholars have successfully applied Agamben's work on sovereign power and violence, which was originally theorized in relation to Nazi camps in WWII, to the United States prison at Guantánamo Bay, the US policy of 
extraordinary rendition, and Israeli policies in Palestine (Gregory 2004; Minca 2007). Others have taken it further afield to argue that gated communities or export-processing zones are spaces of exception, or even that the bounded wonderlands of amusement parks could be fruitfully analysed in this way (Ek 2006). In my view, these applications of Agamben's theory take it too far from its initial, limited focus on sovereignty and absolute violence. In Agamben's theorization what is exceptional is not simply that there is a different set of rules. It is specifically the ability to kill someone, or detain them indefinitely without consequences, while the normal laws are still in place. It is the rendering of a political citizen into a bare life that constitutes exceptional violence. These other spaces where particular laws are altered or not enforced, say in an export-processing zone, deserve scrutiny, but are not examples of Agamben's exceptional violence. There are other ways to theorize these fuzzy spaces in between the legal and illegal, such as Oren Yiftachel's concept of 'gray spacing' or Cecilia Menjívar's concept of 'liminal legality' (Menjívar 2006; Yiftachel 2009).

The India-Bangladesh borderlands demonstrate both the use of exceptional violence in an attempt to expand sovereign authority and its incomplete and contradictory practice. The expansion of the state relies on taking the unknown and making it legible by defining the people and types of activities that are legitimate within a bounded territory (Foucault 1971, 1978). The authority of the state is based in the ability to standardize practices within a particular territory, allowing them to be monitored, administered, and controlled. In the borderlands, the process of instituting state authority occurs primarily through the regulation of the movement of people and goods in and out of the territory (Megoran, Raballand, \& Bouyjou 2005). Borders in general, and fences specifically, are performances of control (Sack 1986). They materialize the authority of the state and its agents to make decisions about law and order in that space. As Willem van Schendel and Itty Abraham argue, the effort to regulate and define practices at the border 'constructs conceptual barriers between illicit bad-guy activity (trafficking, smuggling) and state-authorized good guy activities (trade, migration) that obscure how these are often part of a single spectrum' (van Schendel \& Abraham 2005: 9). The border is a key site for the state to establish the binaries of power that enframe the world as citizen/alien, nation/foreign, here/there, and we/they.

The broad strategies for defining the boundaries between legal and illegal activities within a territory are set in the capital, but the implementation of these decisions is delegated to local officials as the agents of the state in an area. At this point of translation between state strategy and local tactics, 
the claim of sovereignty is deployed, renegotiated, and reinterpreted every day. In the Bengal borderlands, the agents of the state often use the claim of sovereign authority to allow themselves to operate outside the regulations and laws of the state. As a result, clear distinctions emerge between movement that is legal, movement that is illegal but allowed by the agents of the state, and movement that is illegal and results in an exceptional violent response by the agents of the state (Heyman 1999; Jones 2009b). Between 2000 and 2009, over 800 Bangladeshi citizens were killed by the BSF and hundreds more were shot and injured, often without prior warning and without consequences for the border guards (The Independent 2006; The Bangladesh Today 2010).

The different sets of priorities of the state and the border guards are materialized through the two different ways for goods and people to move across the border: first, the official crossing points; and second, the hundreds of gates and rivers that mark gaps in the Indian border fence. A nearly universal strategy deployed by states to organize and regulate the flow of goods and people across their borders is the designation of particular points where movement is allowed to occur (Torpey 2000; Megoran, Raballand, Bouyjou 2005; Sharma \& Wright 2008). At these official crossing points, the traveller submits to the authority of the state by identifying themselves with documents that demonstrate their position in the citizenship regime of the state (Salter 2006, 2008). In the long stretches between these official sites, all movement of people and goods across the border is forbidden. In the past ten years the government of India has constructed fences, roads, and floodlights to regulate these border spaces and to prevent any unauthorized movement. Rather than stopping the flow of goods and people across the border, however, the security fence has directed and intensified the cross-border movements through the gates and rivers controlled by the border guards.

In an interview, a 24-year-old Indian contractor whose company worked on a large section of the fence in West Bengal explained the official purpose of the fence, but also the illegal activities that are still allowed:

Q: Why is the fence being built?

A: The president has demanded it no matter what the cost. The fence must be finished by 2007. The main reason is terrorism. Bangladesh is the only way terrorists can enter India. [...] The second reason is smuggling but that is not as important. Really the government does not care about that. Anyway, that will continue because the border guards will take some money and let it happen. 
While movement across the border is illegal, movement through the border fence - which is located 150 meters away from the borderline, in accordance with a 1974 treaty with Bangladesh - is sanctioned by the Indian state under certain circumstances. This distinction allows the border guards to establish their own system of licit and illicit activities.

The 150-meter zone of Indian territory between the fence and the borderline is not an empty no-man's-land; the land is owned by many small-scale farmers who need access to their fields (Kabir 2005; Jones 2009b). To accommodate these Indian famers hundreds of gates have been constructed and are operated by the border guards. Although these gates and rivers are not official border crossing points, they make the border quite literally porous, as there are hundreds of potential points for people and goods to pass through the border fence.

These gates and rivers function quite differently from the official border crossing points. At official border crossings, the agents of the state judge whether people are citizens of one state or another with valid documents and intentions. Goods are regulated by the state and (in theory, at least) properly taxed. At official crossing points, the view of the state is powerful and individuals submit to the state's authority to decide their legitimacy (Salter 2006). At the gates and river crossings, people do not submit simply to the authority of the state, but specifically to the authority of the border guards. With the weapons and uniforms provided by the state, these individuals decide the types of activities that can be allowed, regardless of whether they are considered legal under the sovereignty regime of the state.

A 46-year-old shop owner in India suggested that Border Security Force (BSF) officials actively try to be posted along the border with Bangladesh so that they can take advantage of the increased authority the fence provides them: 'Those BSF soldiers who are working elsewhere in India want to come and work in Hili [a border town]. They give a bribe in upper levels in order to be posted here. If they stay here for five years they are able to take five lakhs $[500,000$ rupees; US $\$ 11,000]$ then go elsewhere. It is done outside government channels. As long as this continues then the barbed wire fence is worthless.' The ability to make that amount of money is significant, considering the starting salary for an Indian border guard is $255^{\circ}$ rupees per month (US\$57) and the director general of the BSF only makes 26 ,ooo rupees per month (US $\$ 570) .3$ Indeed, the actions of the border guards themselves can easily be understood as examples of resilience in and reworking of their power relations with the Indian state. Although the state sets their salaries and dictates their duties, they have 
subverted its authority by finding alternatives ways to survive beyond their salaries. A 35-year-old taxi driver in India explained how this system works:

Q: How did you go to Bangladesh?

A:I crossed the border. I know a man who was in the business of smuggling in that area. First, he told the BSF that I was going to come. The guard on our side, the Indian, told the other guards on the Indian side and another man told the Bangladesh side. [...] The BDR asked me my name, I said it. Then they asked to see a photo, I showed them. They already had a copy and they compared it then let me go. [...] You do understand about BSF, they earn their money at the border. They earn some money illegally. The brokers run their business by always giving money to the border guards.

The arrangement with the border guards that allows smuggling and migration to occur is called line-ghat. The word ghat usually refers to the steps leading into a pool or pond, but in this case it simply means a gap in the border that allows goods and people to flow through. The line-ghat opens when the correct border guards are on duty and closes again when their shift ends. A 43-year-old smuggler in Bangladesh explained line-ghat as follows:

Those who are the border security officers, the BSF, they are on duty there. All of them are not bad men, some are good. If you want to go, you talk to those good BSF men that speak Bengali and tell them that you need to go for a little bit of time to see some relatives. They say, 'Ok, go ahead. Come back when I am on duty again'. We call this line-ghat. You have to tell them because they are in charge of border security.

His description of what constitutes 'good' and 'bad' behaviour is particularly noteworthy. In his understanding, the border guards are generally bad because they enforce the laws of India and do not allow goods or people to cross the border - but there are also some good men that allow the border to be transgressed.

Although the border guards and fence are meant to enforce the laws of the state, the result is often something different. As individuals who possess the authority to make decisions about life and death, the guards enforce their own authority in the borderlands, not just the sovereignty of the state. Anyone and anything can go across the border for a bribe - the cattle that cross the border even have pink numbers painted on their sides to indicate that the unofficial 'tax' has been paid to the BSF. As van Schendel and Abraham argue, 'Both law and crime emerge from historical and ongoing 
struggles over legitimacy, in the course of which powerful groups succeed in delegitimizing and criminalizing certain practices' (2005: 7).

Of course, some activities in the borderlands do still result in a violent response from the border security forces. Although the violence has increased in recent years with the Indian government and media's representation of the porous border as a terrorist threat, in practice - and from the perspective of borderland residents - the single activity that results in a violent response is not submitting to the authority of the guards in the borderlands. A 34-yearold primary school teacher in India stated: 'My school is only 50 meters from the border. [...] This morning when I went to school I heard that last night either a Bangladeshi or an Indian was trying to cross the border and were fired on by the BSF. They get fired on if they try to cross without bribing the BSF.' A 45-year-old businessperson in India: 'For people that are in a bad situation, those who live hand to mouth, they cannot afford the 1000 or 2000 taka necessary, it is impossible for them. It is hard for them and they cannot go. Even if they have warm feelings for their relatives, if they don't have money they cannot go. Or they go without consulting the BSF and risk their lives.' A 29-year-old smuggler in Bangladesh: 'Recently I had a nephew who was captured by the BSF. He did not give money to the BSF guards, which created a problem.' The 35-year-old taxi driver in India: 'A few days ago someone was crossing the border and they were fired on. The BSF shot them. In the border area ifyou cross the border secretly and they shoot you, you can't do anything about it. They can kill you.'

These killings in the borderlands are exceptional violence, in Agamben's terms, because they happen without warning and without consequence for the border guards. Despite the violence and the large fencing project, however, neither the borderlands nor the entire state territory can be understood as a completely enclosed space of sovereign power where there is a 'state of exception'. Submission to the border guards is not necessarily submission to the sovereign power of the state. Instead, it is submission to the authority of the border guards, specifically, to regulate that space. Although they gain their legitimacy from the sovereignty of the state, they do not simply enforce the laws and regulations of the state, but also their own regimes of licit and illicit practices. The paradox of the borderlands is that the exceptional violence is done in the name of the state but primarily to conduct activities outside the ambit of the state. Furthermore, the extreme violence of the border guards illustrates their weakness and incomplete control of the space. The need to kill hundreds of people to direct the cross-border flows to the gates demonstrates that many people refuse both the state's claim to regulate the space and the border guards' regime of violence. 


\section{Alternatives to Resistance}

Despite the hardening of the border and the institutionalization of the authority of the border security forces, many people continue to find ways to evade both the state-sanctioned territorial line and the violently enforced bribery regime of the border security forces. But should these actions that subvert both the state and the border guards in these less-than-completelyadministered spaces be understood as resistance to sovereign power?

Cross-border movements' potential to be a form of resistance to the nationstate has been a topic of keen interest for many scholars of transnationalism over the past few decades (Bhabha 1994; Mitchell 1997; Blunt 2007; Smith \& Bakker 2008). Katharyne Mitchell argues that cross-border movement is attractive to scholars because 'as borders are normally associated with power relations - the power to keep in or out - the movement across borders, whether they be national borders, disciplinary borders or theoretical borders, carries with it the febrile fascination and flavour of the illicit [... which] provides numerous poststructural theorists the abstract position of inbetweenenss and movement necessary for the leverage of critique to be inserted into linear and containing narratives of space and time' (1997: 101). This critique that some work on transnationalism essentializes state territorial categories and the border is important. In economic geography, Mitchell suggests, cross-border economic flows are often described as either contained by borders or breaching them - and therefore in both cases positing the pre-existence of a clearly defined border that divides discrete spaces. Similarly, the literature on international migration and diaspora tends to reify the home country and the new country as defined cultural spaces that the traveller moves between (Brubaker 2005). As Mitchell puts it, " $[\mathrm{m}]$ igrants leave one contained and defined spatial territory, cross one or more borders, and arrive in another identifiable space' (1997: 103). Indeed, the term 'transnationalism' itself creates the idea that nations are pre-existing categories, which can then be transcended.

Rogers Brubaker terms this problem of assuming the existence of preexisting groups 'groupism'. He argues - here specifically referring to disaporic identity categories - that 'To overcome these problems of groupism [...] we should think of diaspora not in substantialist terms as a bounded entity, but rather as an idiom, a stance, a claim [...] As a category of practice, "diaspora" is used to make claims, to articulate projects, to formulate expectations, to mobilize energies, to appeal to loyalties' (Brubaker 2005:12). Elsewhere, Brubaker (2002) argued that other identity categories including ethnicity, nations, and race should not be understood as fixed things, but rather as perspectives on the world that are always in the process of becoming. 
Brubaker and Mitchell's interventions about the essentialization of state territorial and group identity categories help to reframe borders as always inchoate and incomplete, shifting the discussion about borders away from how pre-existing territorial and identity categories are transgressed to how these never-quite-complete categories of homeland and nation are interpreted, experienced, or ignored. The point is not, as some of the literature in transnationalism might have it, that cross-border connections displace the 'either India or Bangladesh' frame with 'both India and Bangladesh'. Instead, the movement across the border, and the thinking outside the state territorial and identity categories, is better understood as demonstrating that neither India nor Bangladesh are fixed and finalized categories.

Timothy Mitchell makes a similar argument about the dominance-resistance literature. Mitchell argues that utilizing dualistic language to explain power in social practices reifies a dualistic world of dominance and resistance. Mitchell instead suggests 'an alternative approach to the understanding of domination, one that not only avoids the dualism of contemporary social scientific writing but, through an analysis of the process I call "enframing", examines how domination works through actually constructing a seemingly dualistic world' (1990: 547). Power comes from the process of 'enframing', which is the ability to define the categories that order daily life and create the either/or schemes of power. Taking Mitchell's view to the border, the limits of the imagination are established as the border becomes the line that divides one clearly defined state territory from another. This boundary also represents the division of one identity category from another. Consequently, activities that disrupt the moment of enframing, when the either/or binaries of identity, territory, and power are imagined and promulgated, emerge as crucial for understanding alternatives to sovereign power.

Indeed, as Edkins and Pin-Fat (2004) suggest, many actions that are categorized by scholars as resistance are really not, because they cannot result in a fundamental change in the structure of the relationship or the previous enframing of the state. Similarly, Katz's scheme that classifies most actions as resilience and reworking also reserves resistance for situations when contestation can potentially overthrow the polarity of power relations (2004). In terms of sovereign power, although people may break the laws of the state or cross a border illegally, these actions do not fundamentally alter who is the sovereign authority. These actions are in defiance of the sovereign authority, but are not necessarily resistance to the enframing that gives the sovereign its authority.

To move beyond this impasse, Edkins and Pin-Fat suggest two strategies for recreating a space for the contestation of sovereign power (2004). 
Their first suggestion is that sovereign power can be contested through the acceptance of the role of bare life - they use the example of the lone man standing in front of the Chinese tanks near Tiananmen Square -, which through its naked vulnerability exposes the violence of the system. As this chapter demonstrates, this misses the mark because it stems from their misinterpretation of exceptional violence as indicative of absolute authority in an enclosed sovereign space. Here, by disaggregating the sovereign power of the border guards and the sovereign state, exceptional violence is understood as demonstrating weakness and the incomplete control of the state. Their second proposal, however, moves us beyond the debilitating dominance-resistance binary and towards the process of enframing identified by Mitchell. Edkins and Pin-Fat argue that a space for contestation can be created 'through a refusal to draw lines' that would allow sovereign power to be exercised (2004: 13).

\section{Spaces of Refusal}

Political borders are not just a line drawn by the sovereign state: they are the line, par excellence. Therefore, the borderlands - where the performance of sovereignty is often the most visible and where exceptional violence is regularly deployed - emerge as a key site to examine how the incomplete spread of sovereign authority is experienced and understood in everyday life. By manoeuvring outside the gaze of the border guards and by disregarding the lines drawn by the state on the ground and in the imagination, borderland residents continue to think about the people and territory in ways that do not conform to state-sanctioned categories. Rather than the zones of escape of previous generations, where people fled from the ordering regime of the state into unadministered areas, today these are spaces of refusal where the state is present but its power is incomplete and fragmented. These other ways of seeing, knowing, and being are important acts that refuse the sovereign power's claim to define subjects and activities in those spaces.

Movement across the border outside the purview of the state and the border guards is, by design, difficult to locate and analyse, but certainly exists (van Schendel \& Abraham 2005; Rajaram \& Grundy-Warr 2007). At the Bengal border, many people have legitimate reasons to enter the border zone to work their farmland. Other people who intend to cross the border use this zone as cover to allow them to move through the space undetected and unregulated. As a 6o-year-old house cleaner in India explains, 
There are people that take a scythe and bag and cut grass for their animals near the border. By cutting and cutting they cross the border. If anyone asks what they are doing, they say cutting grass. When no one is there, they cross the border. Many people go this way. Sometimes there are holes in the ground. Someone on one side will drop something in the hole. Then someone cutting grass from the other side will go there and pick it up and bring it to their house. Things cross the border in this way.

Even at the more completely securitized spaces near the official crossing points, people find ways to evade dominating authority. The town of Hili, which was divided in half by the 1947 Partition, is one of the few official crossing points between India and Bangladesh in northern Bengal. Although today there is a brick and concrete wall that divides the town in half along the railroad track that marks the border, both sides are still known by the old name of Hili. Border guards patrol both sides of the wall and trucks line up along the road with goods that are passing through customs. Despite all of these performances of security in Hili, there are also many children sitting, playing, and jumping over the wall. As the 32 -year-old chairperson of Bangladeshi Hili explained,

[in English] Right, our country is a poor country. Many people live hand to mouth. Our country has many, many people. Vagabond people, vagabond children, vagabond students, there are many unemployed people in our country. If they bring something from India they are able to make a small profit. They are crossing the border in hopes of making a profit. It is smuggling. It is not large scale but only poor people smuggling. [At the official border crossing point] there is smuggling by under-invoicing and other things, but this is not like that. They are only doing it to eat something. This is at such a small scale that you cannot even call it smuggling. They speak in the same way as they do on the other side. If the country had not been divided then this would not be necessary. It happens only because this is the border area. Children can come and go carrying goods.

The large wall in Hili is meant to prevent all movement across the border. If that is insufficient, the numerous guards are meant to enforce the laws of the state. However, at least at Hili, that dominance relationship has been reworked to allow some transgressions of the border in full view of the agents of the state. While adults are prohibited from jumping over the wall, children can come and go as they please. In the process, connections are maintained across the borders imposed by the state and alternative practices 
persist that demonstrate, albeit through minor cracks in the façade, that the sovereignty of the state is not absolute.

The refusal of an imposed order, however, does not have to include active transgression of the border. It can also be manifested in a refusal to accept state-sanctioned categories of people and territory. This occurs by not accepting an exclusionary vision of who is a Bengali and who should live in Bengal; by not accepting a binary vision of space and identity; and by denying the state the right to define subjects. By thinking outside state categories, what is contested is the discourse that defines the actions of the state and its agents as true and right, while all other practices and knowledge are illegitimate.

In the binary enframing of the state, there is no space for ambivalence or ignorance: everyone is either Indian or Bangladeshi. Everyone must know who they are and where they belong, which defines their existence. Nevertheless, the current state-sanctioned categories of Indian and Bangladeshi are just over 40 years old; other identity categories have been practiced during the lifetimes of many residents, including Pakistani, Hindu, Muslim, Bengali, and British Indian. There are also many more localized categories like Dinajpuri and Rajbongshi.

One of the most widely practiced of these alternative identities is the broadly defined Bengali category that encompasses the people on both sides of the border. A 30-year-old primary school teacher in Bangladesh, who has never visited India, explained the connections he perceived with people across the border: 'Of course they are totally like us. Culture like us. Language like us. Behaviour like us. They don't know Hindi, or any other language, except Bengali. There is no difference at all. Only there is one thing, if I desire to go there from here I cannot.' On both sides of the border there is a persistent, and widely held, view that the 1947 partition of the province of Bengal was a mistake that had predominately negative consequences. A 27-year-old businessperson in India stated:

We did not want the separation. We wanted to be one country. If Bengal was not divided then you would not be able to talk to me here. My house over there [in contemporary Bangladesh], I would have stayed there. The older people in the area are all sad about the state of the country. Hindus and Muslims, everyone in both communities is sad. [...] Those who came here through exchange, they are not happy either. It is an error.

The frustration about the division emerges from the feeling that the current borders do not reflect local history or perspectives. Instead, the border is seen as an imposition by outside forces to weaken and divide the previously 
strong Bengali presence in South Asian affairs. A 65-year-old retired teacher in India stated: 'It is true people are sad [about the division]. Nobody wanted it. But it happened. [...] When it happened, everything was divided, our power, our capacity, our education, our allegiance, everything.' A 38-year-old businessperson in India described it thus: 'Our leaders, they divided us. The people did not want this. By heart we are the same, even if he is Hindu or Muslim. But the leaders in power they divided us. The people in Bangladesh want to come here, we want to go there. That is always in our mind.' His final sentence is the crux of the argument in this chapter. Virtually everyone accepts that the division of Bengal into India and Bangladesh is a settled fact; very few people at this moment are actively contesting the sovereign authority of either country. Nevertheless, many - if not most - people in the borderlands continue to think about the territory and the people in different terms than those set by the state. They abide by state sovereignty, but alternative frameworks are, as the businessperson says, 'always in our mind'.

Indeed, it is not just a united Bengali identity category that persists across the India-Bangladesh divide. On both sides of the India-Bangladesh border in northern Bengal there are small populations of people who are categorized, at least by others, as Adivasi. 'Adivasi' is a broad term used to denote populations that are perceived to be indigenous and not part of the larger Indo-European ethnic, cultural, or religious groups in the area. During the research for this project, several Adivasi families were interviewed in hopes that they would able to provide an alternative perspective on communal religious distinctions and the state categories of Indian and Bangladeshi. A 26-year-old homemaker in Bangladesh responded to our questions as follows:

Q: Can you find a difference between Adivasis and other peoples?

A: Difference? How can I see it? We are all brothers. Everyone. People are people. Everyone is the same kind.

Q: Why do people call you Adivasi then?

A: People have been calling us Adivasi for fourteen generations. What our ancestors did to get this name, we do not know.

Three weeks later and thirty kilometres away, a 56-year-old homemaker in Bangladesh made an identical point:

Q: Is there any difference between Bengalis and Adivasis?

A: What kind of difference can there be between Bengali and Adivasi?

People are one. There are not any differences. 
Q: But if there is no difference why do people still call you Adivasi?

A: People have been calling us that since before my grandfather's time.

What can I say now?

The perspective these women provide, which was reiterated in other interviews, is instructive in its steadfast refusal to be hemmed in by categories and kinds. In their matter-of-fact dismissal of the categories that shape their neighbours' lives, these women question the taken-for-granted logic of the sovereign state as humanity attempts to negotiate the damage modern ordering, bordering, and categorizing have wrought on the world. They provide hope that the violence done through the enframing of the state can not only be endured and reworked, but also undone.

\section{Making Space for the Possible}

One thing I do know is that we are all brothers and our blood is the same.

If I cut you, it is red. Mine is too. (52-year-old businessperson in India)

Moushumi and the thousands of other people like her who live close to the border between India and Bangladesh see the performance of state sovereignty every day. While generations ago there were zones of escape outside the sovereign state system, today most of the territory in the world has been claimed and assigned to a particular state. Flight is no longer an option. Nevertheless, the homogenous maps of the state with clean lines separating different peoples and territories still do not completely dictate everyday existence along the border. People accept that the state is there and a categorical order has been imposed, but they do not necessarily accept those categories. When required they perform their role as subjects of the state, but at other times they continue to think and live in alternative configurations that maintain connections across, through, and around sovereign state territoriality. People in the borderlands smuggle goods across the border, refuse to submit to the border guards, refuse to apply for a passport, refuse to travel many kilometres to an official crossing point, and refuse to accept the authority of the state to regulate their movement. Moushumi refuses to be denied a visit with her son and grandchildren simply because the state has redefined territorial categories in the area.

To understand the significance of these acts of refusal, this chapter makes three arguments about sovereign power at the border. First, although the sovereign state system is represented as administering all of the territory 
in the world, there are many places where sovereign power is new, uneven, and tenuous. In these spaces, sovereign power does operate, but not in the absolute terms claimed by the state, represented on maps, or assumed by some scholars. Rather than beginning with the view that the state has absolute authority in these spaces - which reifies state sovereignty and its claim to power - it should be understood as partial and conflicted, as the agents of the state make contradictory decisions on enforcing sovereign authority every day. The literature on the violence of the exception still needs to be engaged, but in a more critical manner that emphasizes the incomplete and uneven practice of sovereign power. Rather than a generalized state of exception, the focus should be on how, when, where, and why exceptional violence is periodically materialized. There is a moment and a decision by an individual agent, not an all-encompassing state.

Second, this chapter argues for a more nuanced conceptualization of contestation in both the sovereign power and dominance-resistance literatures. Scholars of sovereign power are right to suggest that there is no space for resistance in a completely enclosed sovereign space, where the violence of the exception has become the rule - but the uneven and conflicted practice of sovereignty leaves many not-completely-enclosed spaces within the territory of the state. This chapter demonstrates this temporal and spatial unevenness at the border, where the performances of security and sovereignty are often most conspicuous, but it is also obvious in many other places like neglected urban slums. Indeed, the necessity of the overt performances at the border, and the violence regime of the border guards, demonstrates the incompleteness of the state's claim of sovereignty. At the same time, even in these partially administered spaces, every action in defiance of the state or the border guards should not be understood as resistance. Instead, following Katz, it is more useful to think of many of these actions as a reworking or resilience in a difficult situation. These activities make life possible but do not result in, or even envision, emancipation from that situation.

Third, to get out of the binary enframing of domination-resistance, the concept of 'spaces of refusal' is proposed for conceptualizing the multiple strategies that transgress, reinterpret, and ignore sovereign power, but do not necessarily rise to the level of overt political resistance. Although these activities cannot be understood, or romanticized, as examples of oppositional consciousness that achieve emancipatory change, they are nevertheless important. In these spaces of refusal, the binary enframing of the state is not accepted, which preserves the alternative mental, emotional, and practical networks that could eventually be drawn upon. This is not to say that any of the other categories practiced by people in the borderlands are 
the true and legitimate categories. They are not. All categorical schemes are partial, incomplete, and always in the process of becoming. The argument here is simply that the territorial and identity categories of state subjectivity are not the only option, despite maps and state discourses that attempt to foreclose other possibilities. By emphasizing nuance, fragmentation, and process, the possible remains.

The borderlands, therefore, are both a space where the violence regimes of the state and the border guards are periodically materialized and a space of refusal where situated ways of being and knowing continue to exist. Even as the state ratchets up the performance of its sovereign power by attempting to lock down and close the border, people continue to move and think outside the binary enframing of the state. By not allowing the sovereign power to draw social boundaries between people, and not respecting the territorial lines drawn on the ground, the potential for alternatives is created - even if at the present moment they are not being actualized.

\section{References}

Agamben, G. (1998). Homo Sacer: Sovereign Power and Bare Life. Stanford: Stanford University Press.

Agamben, G. (2005). State of Exception. Stanford: Stanford University Press.

Agnew, J. (2005). Sovereignty regimes: Territoriality and state authority in contemporary world politics. Annals of the Association of American Geographers, 95, pp. 437-461.

Agnew, J. and Corbridge, S. (1995). Mastering Space: Hegemony, Territory and International Political Economy. New York: Routledge.

Bhabha, H. (1994). Location of Culture. London: Routledge.

Blunt, A. (2007). Cultural geographies of migration: Mobility, transnationalism and diaspora. Progress in Human Geography, 31, pp. 684-694.

Brubaker, R. (2002). Ethnicity without groups. European Journal of Sociology, 43, pp. 163-189.

Brubaker, R. (2005). The 'diaspora' diaspora. Ethnic and Racial Studies, 28(10), pp. 1-19. Butler, J. (2004). Precarious Life. New York: Verso.

Calarco, M. and DeCaroli, S. (2007). Giorgio Agamben:Sovereignty and Life. Stanford: Stanford University Press.

Chatterji, J. (1994). Bengal Divided: Hindu Communalism and Partition, 1932-1947. Cambridge: Cambridge University Press.

Chatterji, J. (2007). The Spoils of Partition: Bengal and India 1947-1967. Cambridge: Cambridge University Press. 
DeCaroli, S. (2007). Boundary stones: Giorgio Agamben and the field of sovereignty. In: M. Calarco and S. DeCaroli, eds., Giorgio Agamben: Sovereignty and Life. Stanford: Stanford University Press, pp. 43-69.

Dillon, M. (2004). Correlating sovereign and biopower. In:J. Edkins, V. Pin-Fat, and M. Shapiro, eds., Sovereign Lives: Power in Global Politics. New York: Routledge, pp. 41-6o. Edensor, T. (2002). National Identity, Popular Culture and Everyday Life. Oxford: Berg. Edkins, J. and Pin-Fat, V. (2004). Introduction: Life, power, resistance. In:J. Edkins,

V. Pin-Fat, and M. Shapiro, eds., Sovereign Lives: Power in Global Politics. New York: Routledge.

Ek, R. (2006). Giorgio Agamben and the spatialities of the camp: An introduction. Geografiska Annaler B, 88(4), pp. 363-386.

Foucault, M. (1971). The Order of Things: An Archeology of the Modern Sciences. New York: Random House.

Foucault, M. (1978). A History of Sexuality, vol. 1. New York: Random House.

Ghosh, G. (2002). Outsiders at home? The South Asian diaspora in South Asia. In:

D. Mines and S. Lamb, eds., Everyday Life in South Asia. Bloomington: Indiana University Press, pp. 326-336

Gregory, D. (2004). The Colonial Present: Afghanistan, Palestine, Iraq. Malden, MA: Blackwell.

Heyman, J., ed. (1999). States and Illegal Practices. New York: Berg.

Huq, A. (1984). The problem of national identity in Bangladesh. Journal of Social Studies, 23, pp. 47-73.

Hussain, N. (2003). The Jurisprudence of Emergency: Colonialism and the Rule of Law. Ann Arbor: University of Michigan Press.

Jones, R. (2009a). Geopolitical boundary narratives, the global war on terror and border fencing in India. Transactions of the Institute of British Geographers, 34, pp. 290-304.

Jones, R. (2009b). Agents of exception: border security and the marginalization of Muslims in India. Environment and Planning D: Society and Space, 27, pp. 879-897.

Kabir, E. (2005). Border Fencing: A Major Irritant in Indo-Bangla Relations. Dhaka: News Network.

Katz, C. (2004). Growing Up Global: Economic Restructuring and Children's Lives. Minneapolis: Minnesota University Press.

Martinot, S., ed. (2001). The Problems with Resistance. Amherst, NY: Humanity Books.

Megoran, N., Raballand, G., and Bouyjou, J. (2005). Performance, representation, and the economics of border control in Uzbekistan. Geopolitics, 10, pp. 712-740.

Menjívar, C. (2006). Liminal legality: Salvadoran and Guatemalan immigrants' lives in the United States. American Journal of Sociology, 111, pp. 999-1037.

Minca, C. (2007). Agamben's geographies of modernity. Political Geography, 26, pp. 78-97.

Ministry of Home Affairs (2008). Annual report. http://mha.gov.in 
Mitchell, K. (1997). Transnational discourse: Bringing geography back in. Antipode, 29(2), pp. 101-114.

Mitchell, T. (1990). Everyday metaphors of power. Theory and Society, 19, pp. 545-577.

Murphy, A. (1996). The sovereign state system as political-territorial ideal: Historical and contemporary considerations. In: T. Biersteker and C. Weber, eds., State Sovereignty as Social Construct. Cambridge University Press: Cambridge, pp. 81-120.

Murphy, A. (2005). Territorial ideology and interstate conflict: Comparative considerations. In: C. Flint, ed., The Geography of War and Peace: From Death Camps to Diplomats. New York: Oxford University Press, pp. 280-296.

Murshid, T. (1997). State, nation, identity: The quest for legitimacy in Bangladesh. South Asia, 20, pp. 1-34.

Murshid, T. (2001). Nations imagined and fragmented: Bengali ethnicity and the breakup of Pakistan. In: W. van Schendel and E. Zürcher, eds., Identity Politics in Central Asia and the Muslim World:Nationalism, Ethnicity, and Labour in the Twentieth Century. New York: I.B. Tauris Publishers, pp. 85-106.

Neocleous, M. (2008). Critique of Security. Montreal: McGill-Queen's University Press.

Ortner, S. (1995). Resistance and the problem of ethnographic refusal. Comparative Studies in Society and History, 37(1), pp. 173-193.

Pile, S. and Keith, M., eds. (1997). Geographies of Resistance. New York: Routledge. Rajaram, P. and Grundy-Warr, C., eds. (2007). Borderscapes: Hidden Geographies and Politics at Territory's Edge. Minneapolis: Minnesota University Press.

Rose, M. (2002). The seduction of resistance: Power, politics, and a performative style of systems. Environment and Planning D: Society and Space, 20, pp. 383-400.

Roy, A. (1984). The Islamic Syncretistic Tradition in Bengal. Princeton: Princeton University Press.

Sack, R. (1986). Human Territoriality: Its Theory and History. Cambridge: Cambridge University Press.

Salter, M. (2006). The global visa regime and the political technologies of the international self: Borders, bodies, biopolitics. Alternatives, 31, pp. 167-189.

Salter, M. (2008). When the exception becomes the rule: Borders, sovereignty and citizenship. Citizenship Studies, 12, pp. 365-38o.

Schmitt, C. (1996). The Concept of the Political. Chicago: University of Chicago Press.

Scott, J.C. (1985). Weapons of the Weak. Princeton: Princeton University Press.

Scott, J.C. (2009). The Art of Not Being Governed: An Anarchist History of Upland Southeast Asia. New Haven: Yale University Press.

Sharma, N. and Wright, C. (2008). Decolonizing resistance, challenging colonial states. SocialJustice, 35, pp. 93-111.

Sharp, J., Routledge, P., Philo, C., and Paddison, R. (2000). Entanglements of Power: Geographies of Domination/resistance. New York: Routledge. 
Smith, M. and Bakker, P. (2008). Citizenship Across Borders: The Political Transnationalism of El Migrante. Ithaca: Cornell University Press.

Sparke, M. (2008). Political geography: Political geographies of globalization III: Resistance. Progress in Human Geography, 32, pp. 423-440.

The Bangladesh Today (2010). BSF kills another Bangladeshi. 27 April.

The Independent (Bangladesh) (2006). BSF, Indian miscreants kill 461 Bangladeshis in 6 years, Odhikar. 08 January.

Torpey, J. (2000). The Invention of the Passport: Surveillance, Citizenship and the State. Cambridge: Cambridge University Press.

Vacarme (2004). 'I am sure that you are more pessimistic than I am...': An interview with Giorgio Agamben. Rethinking Marxism, 16, pp. 115-124.

van Schendel, W. (2005). The Bengal Borderland: Beyond State and Nation in South Asia. London: Anthem Press.

van Schendel, W. and Abraham, I., eds. (2005). Illicit Flows and Criminal Things:

States, Borders and the Other Side of Globalization. Bloomington: Indiana University Press.

Yiftachel, O. (2009). Critical theory and 'gray space': Mobilization of the colonized. City, 13, pp. 240-256.

\section{About the Author}

Reece Jones is a Professor of Geography and Environment at the University of Hawai'i at Mānoa. He is the author of two books, Border Walls: Security and the War on Terror in the United States, India and Israel (2012, Zed Books) and Violent Borders: Refugees and the Right to Move (2016, Verso). He also edited Placing the Border in Everyday Life with Corey Johnson (2014, Routledge Border Regions Series) and Open Borders: In Defense of Free Movement (2018, University of Georgia Press). 


\title{
$2 \quad$ Border Layers
}

\author{
Formal and Informal Markets Along the India-Bangladesh \\ Border
}

Edward Boyle and Mirza Zulfiqur Rahman

Jones, Reece and Ferdoush, Md. Azmeary (eds), Borders and Mobility in South Asia and Beyond. Amsterdam: Amsterdam University Press, 2018 DOI: $10.5117 / 9789462984547 / \mathrm{CHO} 2$

\begin{abstract}
This chapter argues that the border between India and Bangladesh serves as a site for formal and informal structures of interaction and exchange, with various actors and processes complementing, contesting, and overlapping in their functions and priorities. While the respective national governments seek to encourage cross-border trade and promote economic corridors, these national policies find local reflection in the much-trumpeted establishment of border haats, or official cross-border markets. A close examination of the political processes shaping this border policy reveals both India's desire to simplify its own edges and the multi-layered and contradictory manner in which this policy is implemented at the border itself. Based upon fieldwork conducted in Meghalaya and Tripura, this chapter examines how the multi-layered infrastructure of border management and governance affects local community interactions and flows of goods, political processes, and cross-border connectivity.
\end{abstract}

Keywords: Northeast India, Bangladesh, informal markets, border haats, border infrastructure 


\section{Introduction}

On a patch of land where the Khasi Hills fade into the plains of Sylhet, a market is held on every fifth day. ${ }^{1}$ This market is operated by local residents to facilitate the exchange of goods between two distinct groups of people. The Khasi highlanders bring with them the fruits of their forest plots - betel nuts, oranges, gourds, and, when in season, pineapples - and begin to gather from the morning, drinking tea and buying from and selling to one another amid the profusion of semi-permanent trading stalls, thrown together from wood and concrete. They are there to await the appearance of the market itself later in the day, which occurs once their counterparts make themselves ready. The Bengali farmers who form the other side of this exchange bring their harvest with them - a collection of aubergines, tomatoes, huge green beans, and cauliflowers - together with fish and non-agricultural products like plastic toys and helium balloons. Trade between these two groups, who are largely unable to speak one another's languages, is smoothed over by the presence of a number of self-appointed translators, who take up stations behind groups of traders and facilitate the process of exchange. In the main, the market looks like an excellent demonstration of comparative advantage, with the distinct agricultural 'baskets' of the plains and hills being brought together for the profit of all concerned. Yet the local geography that gave rise to the distinct patterns of residence and livelihood that characterizes these two groups of people has also led to a further division over the past 70 years, one with effects that have remained largely unexercised to date, but which are potentially far-reaching. For clearly visible, just beyond the tree line at the base of the hills beneath which the market occurs, is a boundary marker, denoting the international border between India and Bangladesh. For the market to be held, the Bengali farmers must march across the fields in which the marker stands and congregate at the base of the hills with their goods, and in so doing violate the sanctity of the modern state's territorial boundaries.

While local memory cannot recount the origins of this market, which will henceforth be referred to as the Khasi Hills Market, the pattern of exchange between the peoples of the hills and plains that it represents is far older than the modern nation-states of India and Bangladesh, or the demarcated territorial borderline that runs between them. Although this market has

1 If a market is on the Monday, the next one would be on Friday. The exception is when the fifth day falls on a Sunday, in which case the market is shifted to Monday to accommodate the devoutly Christian Khasi market-goers. 
until recently escaped the gaze of the state, unlike the carry-trade occurring in places like Hili (see Chapter 1), exchange here does not occur because of the border. Instead, the border serves as an additional institutional obstacle to be negotiated so that the market, and others like it, can be held.

This chapter inquires into how we can incorporate such zones of crossborder exchange into our wider understanding of the boundary running between Bangladesh and India's Northeast. In recent times, local administrations and national governments in the region have come to show an interest in sanctioning variations of spaces like these to promote economic development. At the same time, it is along this boundary between Bangladesh and India that New Delhi's claims to secure the body of the nation are most stridently asserted through the creation of fencing along the border's entire length. This seeming contradiction highlights that the manner in which the border is understood to be functioning changes according to the scale at which it is viewed. The chapter will begin by briefly setting out the notion of 'border layers' as a means of grasping such scales of operation, before moving on to examine the concept's empirical application to the spaces of local exchange along stretches of Bangladesh's border with Northeast India. It will then conclude by briefly reflecting upon the utility of understanding the border as layered.

\section{Border Layers}

The Khasi Hills Market offers an excellent example of the discrete layers through which the border between India and Bangladesh functions. The local residents on both sides of the border who come together at this market are perfectly cognisant of the national boundary between them and the need for it to be crossed for trade to occur. To do so, they are forced into negotiations with agents of the state whose sanction is required for such markets to go ahead. The markets are thus regulated and ordered by those 'petty sovereigns' who are charged with maintaining the state's authority, yet take place without official recognition from either New Delhi or Dhaka. While at the national layer, as we detail later, the border is envisaged as a line across which the movement of people and goods is made legible and controlled by the state's sovereign authority, locally neither the presence of the boundary line nor those responsible for its enforcement prevent the type of small-scale exchange visible at markets such as this.

Our invocation of 'border layers' appears to tally with a number of approaches in border studies, including the invocation by Chris Rumford of 'multiperspectival borders' as well as recent references to the 'polysemy' 
and 'multiplicity' of borders (Rumford 2012; Balibar 2002; Sohn 2016). These concepts stem from an understanding of borders that has long acknowledged that it 'is the process of bordering, rather than the border outcomes per se, which should be of interest to all border scholars', and that consequently we need to focus on the 'multiscalar production of borders' (Newman 2006: 148; Laine 2016). In the account offered above, however, it appears that the various 'layers' at which the border are produced operate in an entirely independent fashion: the local border at the base of the Khasi Hills and the national one visible on maps in New Delhi seem to have very little to do with one another. As noted, however, recently, the Northeast region has seen the granting of official sanction for such local markets through the introduction of official border haats ('markets'). This chapter argues that such a development highlights how the border's layers, the various scales at which it is constituted, are not autonomous, but interact with one another in a manner ensuring that the border is always in a process of transition.

The interplay between expressions like local, regional, and national in the previous paragraph suggests how the boundary of the state manifests in different ways at the various layers at which the state's borders function. The notion of 'border layers' adopted here does not seek to reify the various layers (local, regional, national) at which the borders of the state are produced, although in the absence of any alternative such terms will be used. Rather, the aim is to trace how the border exists both institutionally and discursively at various layers, and how these layers impact one another. Doing so not only allows us to understand that the sovereign authority associated here with New Delhi must inevitably be multifaceted, partial, and conflicted, but also through the presence of multiple layers helps us to appreciate that neither 'resistance' nor 'refusal' provides us with a complete explanation for what is occurring along this border (see Chapter 1 ).

The examples of the Khasi Hills Market and the recent sanctioning of such spaces as border haats indicate how the various border layers are bound up with one another. The first section below shows how the introduction of the border haats is indicative of a regional transformation in perceptions of the border. The second section highlights how this transformation of border functions in India's Northeast stems from the invocation of a variety of national goals, which can result in policies that appear to push in different directions, as in the example of fences and haats noted here. The third section situates this transformation within a broader context, indicating how changes at the border are being driven by both foreign policy aims and wider trends visible in borders elsewhere. The final section returns to the space of the border itself, and the local layer within which it functions. 


\section{Sub-regional Spaces of Exchange}

The lives of those residing in the vicinity of the border incorporate multiple practices of exchange, both licit and otherwise. The Khasi Hills Market described above is considered an example of unofficial border exchange because the existence of the market remains unknown to the central administration in distant New Delhi, at least officially. ${ }^{2}$ Consequently, the international trade and border-crossing that are necessary for the market to occur are unsanctioned by the state. Strictly speaking, the exchange that occurs at such informal markets forms part of the vast quantity of goods known to be smuggled across the India-Bangladesh border, although the Indian state is generally far more concerned with the large-scale passage of obviously illicit goods across the border, such as fake Indian currency notes, guns, and drugs, as well as the export of cattle to Bangladesh (Tiwary 2015). Although informal markets such as this seem to offer nothing more nefarious than the odd plastic toy gun, the exchange taking place there is illegal due to the absence of the involvement the state's customs agents, as well as the border violations that are necessary for the market to take place.

The prioritization of certain flows over others demonstrates the institutionalization stemming from the state, which through its activities creates distinct layers of border flows, ranging from those adjudged and treated as highly illicit and dangerous to those occurring between local communities without official recognition. These unofficial markets exist in lieu of a statesanctioned border trade. While the Northeastern province of Meghalaya, ${ }^{3}$ in which the Khasi Hills Market is located, does possess a total of eleven Land Custom Stations (LCS) along its border with Bangladesh, only six are active; and these do not serve to facilitate the kind of local barter trade that occurs at the unofficial markets. ${ }^{4}$ Similarly, in nearby Tripura, which is surrounded by Bangladesh on three sides, an official cross-border trade with

2 This does not mean that the state is not aware of these markets, or that no one in New Delhi pays attention to their existence. However, these markets are not sanctioned by the state, and thus are not 'legible' to it.

3 Under India's federal structure, its constituent administrative divisions are officially 'states'. However, as this invites confusion here with references to the nation-state of India, we will refer to these here as 'provinces'.

4 'Appears to possess' might be a more accurate phrase, as different numbers are given by different authorities. This figure, and the one for Tripura that follows, is based on the website of the Ministry of Development of North Eastern Region, but the data may refer to 2012 or earlier: http://mdoner.gov.in/node/1474. In any case, several are inactive, others are only allowed to export an extremely restricted range of goods, and the upgrade of Dawki to an ICS or Integrated Check Post has coincided with the absolute collapse of trade at that border crossing. 
Figure 2.1 Land Customs Stations in Northeast India

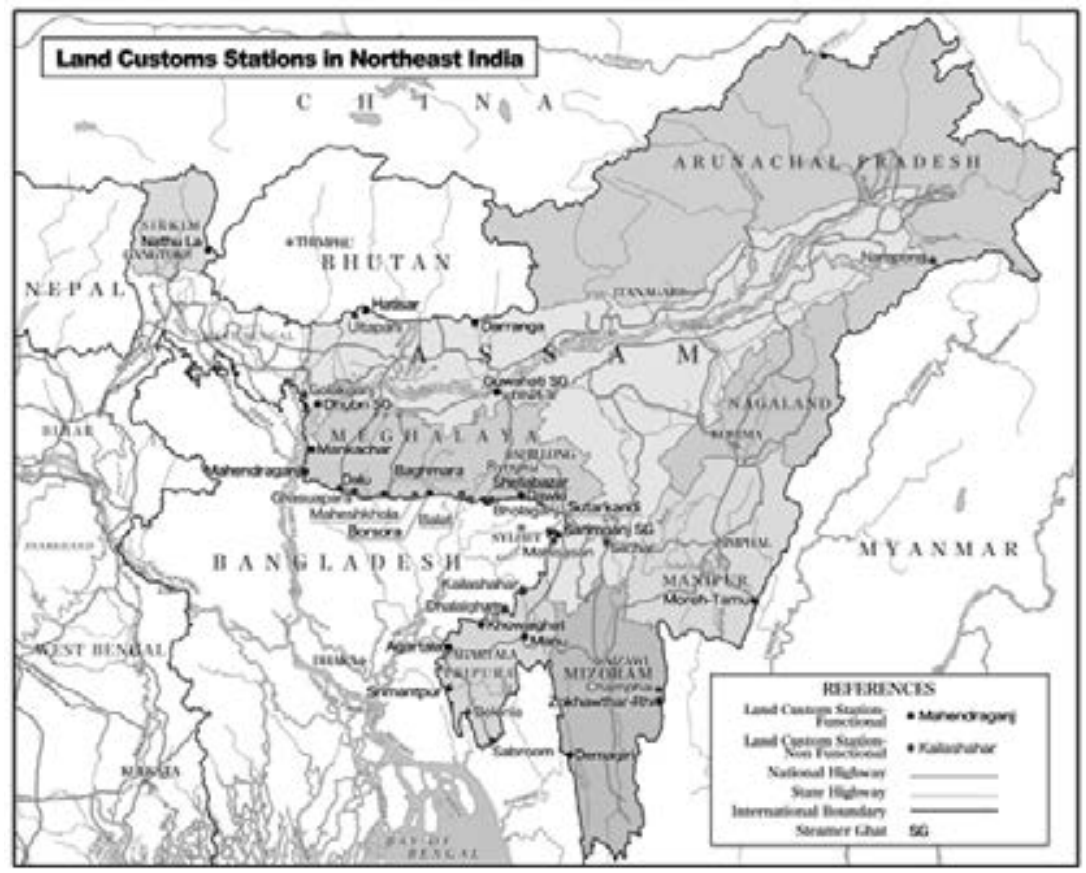

Bangladesh through eight notified LCSs was restarted in 1994-1995 ${ }^{5}$ - but as in Meghalaya, four are currently inactive, and those that are functioning are unsuitable for more small-scale, local trade.

Recently, however, increasing attention has been paid to reviving what India officially terms the 'border trade' along its boundary with Bangladesh. This policy has found expression in Meghalaya and Tripura with the setting-up of border haats. ${ }^{6}$ These are markets for the local exchange of

5 It is not clear if there are in fact seven, eight, or nine LCSs, and whether the ones shown here are correct, as MDONER's own website provides both a list of eight LCSs and a map of them, on which the map in this chapter is based. Two LCSs listed are not shown on the map, while one on the map is not on the list. The authorities in Tripura have been less than forthcoming in clarifying the issue. We have assumed here that the 'Old Raghnabazar' LCS listed is the same as the one marked as 'Kailashahar' on the map. As both are marked as currently inactive, the issue is not so important, but the representation given here should not be considered definitive. 6 Border trade is officially defined 'as overland trade by way of exchange of commodities from a bi-laterally agreed list by people living along both sides of the international border', see http://mdoner.gov.in/content/border-trade. Haat is a word, in Assamese, Bengali, Hindi, and other subcontinental languages, referring to a market held at regular intervals in rural areas (as opposed to a bazaar, referring to permanent markets). 
agricultural produce established on the international zero-line, with one part of the market located on the Indian side of the border and the other in Bangladesh, providing a space in which locals from both sides of the border are able to gather and trade together. In both India and, perhaps more urgently, Bangladesh, the border haats are presented as revivals of former trade practices, with similar markets, often on the same locations, understood as having flourished from Mughal times right up until either the founding of Pakistan (Economic Times 2011) or the aftermath of the Bangladesh Liberation War (Sohel 2014).

In fact, this trade was initially recognized in the agreement signed between India and the newly-independent Bangladesh on 28 March 1972, which provided for small informal trade among people living within a 16-kilometer belt of the border in the Indian provinces of West Bengal, Assam, Meghalaya, Tripura, and Mizoram, on one hand, and Bangladesh on the other. ${ }^{7}$ However, concerns over smuggling meant that in October 1972 the provision for border trade was discarded from the Agreement by mutual consent (Wirsing \& Das 2016: 23). From the perspective of the state's centre, therefore, this kind of local trade in products of limited value by border residents did not occur between late 1972 and the recent opening of border haats under the state's aegis.

The respective governments of India and Bangladesh remain officially unaware of the existence of places of unsanctioned exchange like the Khasi Hills Market. However, the last two decades have seen the articulation of the kinds of local, negotiated cross-border interactions that are visible at such unofficial border markets in the national-level agreements between India and its neighbours in the region. This is indicative of a shift in thinking about the border of the nation, in which the edge of the state is transformed from a linear barrier into a zone of permeable interaction mandated by the state.

\section{National Goals}

The interest of the political centre in the Northeast region's local trade appears to have first manifested on its eastern border, in an agreement that India signed with Myanmar on 21 January 1994 (Bhatia 2016: 231). According to this agreement, in addition to the normal cross-border trade conducted

7 'Trade Agreement between the Government of India and the Government of the People's Republic of Bangladesh', Article IV. 
through Land Customs Stations on the Indian side of the border (initially at the Moreh-Tamu crossing in Manipur, established on 12 April 1995, with stations later added at Zokhawthar-Rhi in Mizoram and Nampong in Arunachal Pradesh), trade in a restricted list of products was permitted for residents living within $40 \mathrm{~km}$ of the border. ${ }^{8}$ The list of bilaterally agreedupon 'traditional' products first consisted of 22 items of largely agricultural produce, but has since been expanded to 40 (in 2008), and then 62 (from 2012) items, and now incorporates goods whose exchange is somewhat less hallowed by custom, including motorbikes, electrical appliances, and agricultural machinery. Trade by the locals in these 'traditional' products is duty free and conducted alongside the 'normal' cross-border trade at land customs stations. $^{9}$

The recognition of local border trade by the Indian state was subsequently expanded to incorporate a border trade with China, as agreements reached as part of the Confidence-Building Measures in the early-199os were followed with a further Memorandum of Understanding in 2003 and finally applied to trade at the Nathula Pass in Sikkim. ${ }^{10}$ These agreements allowed for the import of fourteen items to India and the export of 29 (since expanded to 20 and 34 (Das 2014: Appendix 1)) entirely duty-free, while also specifying the length of the trading season, on which days the market would be held, and charging levies on vehicles. That same year, 2006, also saw the signing of the South Asian Free Trade Agreement (SAFTA) which, although hardly as comprehensive or effective as its architects envisaged, was indicative of a desire among the states in the region to ameliorate the effects of the traditionally punitive tariff barriers. Two years later an agreement to resume border trade was signed between India and Pakistan.

It is in the wake of these national and regional exemplars that the last decade has seen moves to legitimize the border trade between India and Bangladesh as well, through the introduction of border haats. In October 2009, it began to be reported that Bangladesh had finally dropped its opposition to the 'reopening' of these border markets; the decision to establish the

8 Unlike the other two land customs stations, there is not yet any 'normal/MFN' trade permitted at Nampong.

9 In December 2015 the Indian government suspended the 'barter' system that had been previously utilized in trade with Myanmar, and this has slowed the 'official' border trade to a crawl (Htwe 2016; Roderigues 2016).

10 The Confidence-Building Measures were 'The Memorandum of Understanding (MoU) on the Resumption of Border Trade' signed on 13 December 1991 and the 'Protocol on Entry and Exit Procedures for Border Trade' signed on o1 July 1992. 
markets was officially made in January 2010, on the occasion of the historic visit of Bangladeshi Prime Minister Sheikh Hasina to New Delhi (Ministry of External Affairs 2010). Subsequently, a Memorandum of Understanding and Mode of Operation for the border haats was signed between India and Bangladesh on 23 October 2010. These border haats are specifically designed to allow the local residents on opposite sides of the border to trade with one another for locally-produced goods, primarily agricultural and horticultural produce; the markets are supposed to consist of an equal number of traders from both sides, utilizing either side's currency or bartering for goods. ${ }^{11}$ Only those resident within $5 \mathrm{~km}$ of the haat are permitted to trade, and the value of purchases on any given day cannot exceed the equivalent of US\$50 (raised to US\$100 in 2012).

However, despite the extremely small scale of the trade envisaged at these sites, establishing them appears to have been a torturous process for all concerned. The first was declared open for business on 23 July 2011, at Kalaichar (in the West Garo Hills district of Meghalaya)-Baliamari (in the Kurigram district of Bangladesh), and was inaugurated by the then-Union Commerce Minister Anand Sharma and his Bangladeshi counterpart Faruq Khan (Talukdar 2011). ${ }^{12}$ A second haat in Meghalaya was opened on 1 May 2012 at Balat (East Khasi Hills district)-Dalora (Sunamganj district); 13 January 2015 saw the Commerce Ministers of both countries, Nirmala Sitharaman and Tofael Ahmed, jointly open the first border haat in Tripura at Srinagar (South Tripura district)-Purba Madhugram (northeastern Feni district). This was followed on 11 June that year by a further haat in Tripura at Kamalasagar (in Sipahijala district)-Kasba (in the Brahmanbaria district of Bangladesh) (New Indian Express 2015). The latter had officially been inaugurated the previous Sunday by both countries' Prime Ministers via videoconference link, and all of these haats have subsequently received that definitive sanction of their physical existence, representation on Google Maps (Times of India 2015). ${ }^{13}$

11 The commodities permitted for trade are as follows: 1) vegetables, food items, fruits, spices; 2) minor forest produce, e.g., bamboo, bamboo grass, and broomsticks, but excluding timber; 3) products of cottage industries like gamchas, lungis, etc.; 4) small agricultural household implements, e.g., dao, ploughs, axes, spades, chisels, etc.; 5) garments, melamine products, processed food items, fruit juice, toiletries, cosmetics, plastic products, aluminium products, and cooking utensils.

12 See the local administration's report on this haat at: http://southwestgarohills.gov.in/ kalaichar_border_haat.pdf.

13 Although for a long time only the ones in Tripura were visible, by November 2016 those for Meghalaya were also present. 
Figure 2.2 Locations of Border Haats along the India-Bangladesh Border

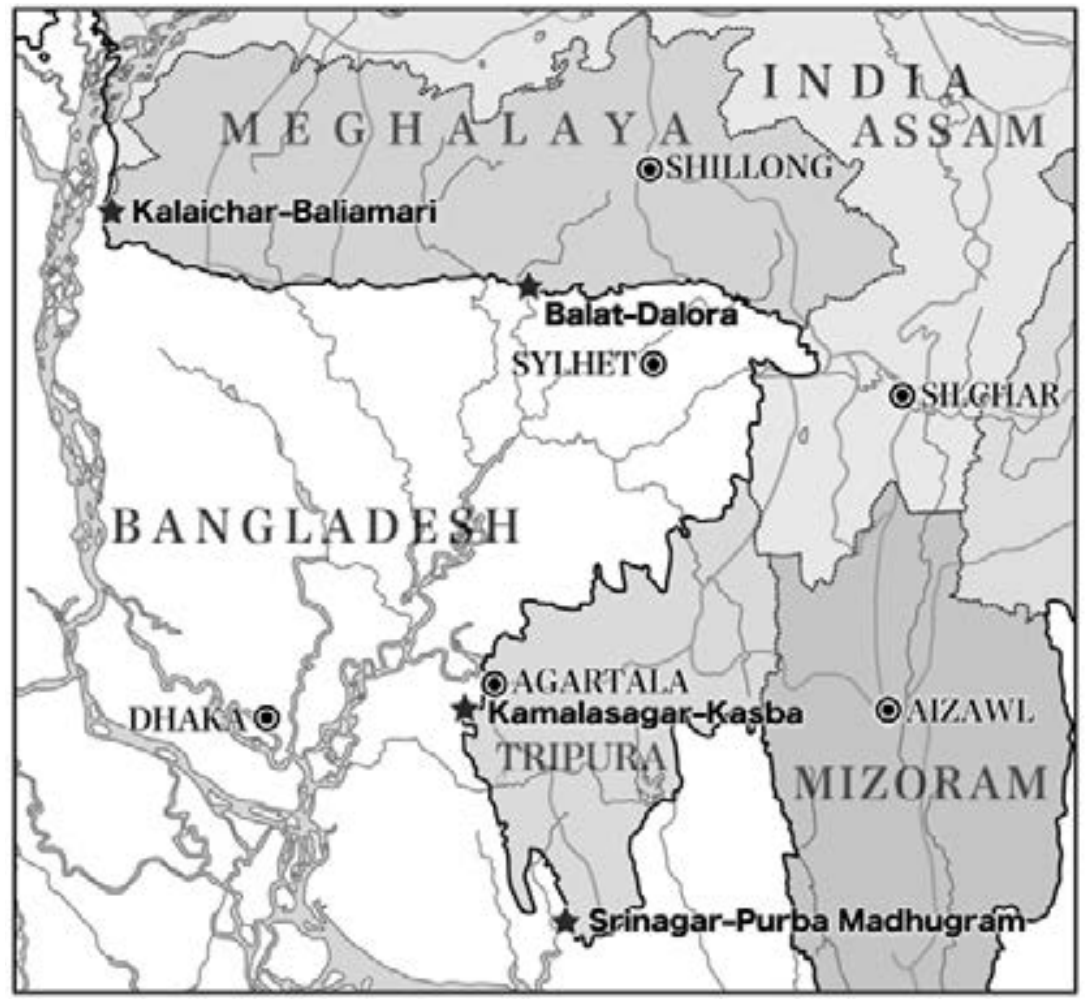

The short histories of these haats render it difficult to make definitive judgements in regards to their stated aims of reopening trade routes severed by Partition, supporting the development of remote border communities, and improving people-to-people contact along the border, but reporting on them to date does suggest that their impact has been positive (Bhattacharyal 2015). Their perceived success is also reflected in demands for more haats to be opened. As early as November 2012, the Grand Council of Chiefs in Meghalaya (GCCM) was requesting a further 38 haats be opened along that province's border with Bangladesh (Meghalaya Times 2012), while in 2015 it was being reported that 'India in consultation with the Bangladesh government and respective state governments has identified 70 locations in five border states to set up the "Border Haats" in a phased manner' (Assam Tribune 2015). This would consist of 35 haats in West Bengal, 22 in Meghalaya, five in Tripura, and four each in Assam and Mizoram, with an additional fifteen haats also being proposed for the India-Myanmar border 
(BanglaNews24 2014). In January of 2016, India's BJP-led cabinet granted ex-post-facto approval for the original 2010 Memorandum of Understanding signed by the previous Congress-led government, while also announcing that the two national governments had agreed to the establishment of four more border haats in Meghalaya and two more in Tripura (PMINDIA 2016). While the pace and scale of the expansion in the number of these border haats remains somewhat opaque, that the system will be extended does not seem to be in doubt. ${ }^{14}$

The Indian state's rationale for sanctioning this border trade is seen to stem from two main factors. The first is the remoteness of these border areas, which does not allow local people access to commercial centres to sell their products or buy items of daily necessity within their national borders. The second is the traditional socio-cultural ties and economic complementarity that these people share across the border, which provides them with a natural milieu for greater economic interactions (Das 2014: 5). It is not necessary here to belabour the point that these (local and contingent) advantages would apply irrespective of whether the state is involved in sanctioning the local border trade at the border haats, or if it occurs outside of its purview, as with the Khasi Hills Market. This strongly suggests that neither India nor Bangladesh is simply a disinterested facilitator of this trade, or acting solely out of a concern for those living in the borderlands. ${ }^{15}$

This is particularly apparent because the Indian government is sanctioning such opportunities for cross-border commerce while simultaneously fencing the entirety of the border's $4000 \mathrm{~km}$-plus length. ${ }^{16}$ This is explicitly done to prevent the flow of people and material across the boundary with Bangladesh, and consequently the border itself appears distinctly Janus-faced, both opening and closing at once. Local demands for further cross-border trade opportunities paradoxically represent both the state's increasing receptiveness to the importance of this trade

14 In November 2016, it was being reported that the forthcoming renegotiation of the border haat agreement between India and Bangladesh will lead to the opening of at least six new haats (Nagorik Kontha 2016).

15 India is also funding the requisite road and infrastructure upgrades necessary to bring these haats online, though one suspects the slightly breathless reporting of this in New Delhi may not be matched by actual improvements on the ground.

16 Of which $1880 \mathrm{~km}$ is with the Northeast: $856 \mathrm{~km}$ with Tripura, $443 \mathrm{~km}$ with Meghalaya, $318 \mathrm{~km}$ with Mizoram and $263 \mathrm{~km}$ with Assam. Whether this will be finished in 2017 appears debatable, and in any case parts of the fence are in such poor repair that the project is likely to be a Sisyphean task. See van Schendel 2005 for the background and Jones 2012 for more recent effects. 
for security and development and the increasing pressure placed on unsanctioned markets as a consequence of the growing prevalence of fencing and tightened security at the boundary. In their introduction to a recent special issue on borders in India's Northeast, Willem van Schendel and Erik de Maaker note how, in Asia as elsewhere, economic growth leads to a 'strengthening' of states (by which they mean an increase in their institutional capacity) and consequent efforts to buttress national borders (2014:4). However, the seemingly contradictory nature of the policies being pursued towards the border reflect not only this growth of 'infrastructural power' (Mann 1984), but also the wider trends frequently observed in the study of borders.

\section{International Development(s)}

Studying borders requires more attention to their layered nature because doing so provides us with a way to get a handle upon the paradoxical character of the border itself. This paradox has been apparent worldwide over the last two decades: the initial post-Cold War focus on the debordering effects of economic integration has shifted to studies of borders that are forced to emphasize the persistent concern of states to (re)secure their national boundaries. As James Sidaway argues, 'it's become a sad cliché' to note the proliferation of walls and fencing since 1989, and India's border with Bangladesh proves no exception to this rule, given New Delhi's apparent determination to complete the fencing of its entire length by 2017 (2015: 214). ${ }^{17}$ This fencing has been primarily justified on the grounds of restricting Bangladeshi migration into India and preventing certain security threats (most recently Islamic terrorism, although there is a far longer history of cross-border insurgencies in the region) from taking advantage of the border by sheltering within and operating from a different jurisdictional space (Wirsing \& Das 2016). As indicated in Chapter 1, this fencing should be understood as indicative of the central government's desire to materialize its sovereignty right up to the edge of its territorial extent by accepting or denying the access of individuals into the body of the state. That such a fence is deemed necessary, of course, is indicative of the difficulty that states, in South Asia as elsewhere, experience in asserting effective control of their

17 See, e.g., Indian Express 2016. There appears to be some confusion in reports as to whether this refers only to Assam and Tripura or to the entire length of the border. If the latter, it is impossible that it will materialize by 2017 . 
boundaries. While markets like the one at the foot of the Khasi Hills confirm van Schendel's assertion that the state 'is never the overarching entity' in the borderlands, such examples of local cross-border connections contrast with different locales along the same border where the 'potential to be reduced to bare life is ever present' (van Schendel 2005: 380; Sur 2015: 77; Jones 2012: 144). As the distant central state lacks an 'overarching' control of its own sovereign territory, it is acutely aware of (and thus 'cartographically anxious' about) its own insecurity, to the point that these 'sensitive spaces' trigger the ruthless response that has transformed large sections of the India-Bangladesh borderland into a 'killing field' (Krishna 1994; Cons 2016; Human Rights Watch 2010). However, as both official and unofficial border markets demonstrate, to characterize the entire length of the borderline as a space of exception fails to do justice to the multi-layered existence of the border, which is capable of simultaneously recognizing and rejecting the necessity of cross-border interactions. It is the somewhat paradoxical nature of the border, which possesses both filtering and barrier functions, that makes these two trends able to exist as different layers of the same boundary.

This is emphasized by the fact that the recognition of border trade has not occurred in isolation from New Delhi's security concerns. With Myanmar and China, too, the question of recognizing a limited border trade became part of bilateral relations through its incorporation into wider issues of regional politics. The trade deal with Myanmar reflected India's need for a cross-border agreement in order to secure land access to Southeast Asia, while border trade with China was proposed as part of confidence-building measures seeking to receive the latter's recognition of India's incorporation of Sikkim (Economic Times 2003). These wider goals also share a concern with maintaining and supporting the sovereign borders of the nation, and the border trade with Bangladesh is no exception in this regard.

The border itself has recently been presented as an engine of growth, with a reinterpretation of how India's Northeast is seen from New Delhi that is sufficient to propel a new emphasis on the development of connectivity (Rana \& Uberoi 2012). Nevertheless, the reluctance of the state to trust local actors and patterns of governance means that this invocation of mobility has exaggerated the state's concern with the management and monitoring of flows. It should be remembered that while in Dhaka and New Delhi it is obvious that these border haats are the outcomes of a new policy that seeks to revive patterns of trade and local exchange disrupted by Partition, this may not reflect realities along the border - as our account of the unofficial border trade with which we began this chapter suggests. It is more accurate to see these newly established border haats as moves by the respective states 
to grant an official sanction to unofficial markets. ${ }^{18}$ Their introduction is seen as essential for forestalling local opposition to the fencing of the border and increasing border security by drawing locals into systems of exchange that are officially mandated and controlled by the state.

This official sanction enables the state to incorporate these markets into wider narratives regarding both security and cross-border connectivity in the Northeast, enabling these local relations to be reconstituted as international flows that transverse the region, rather than merely existing upon its edges. This more expansive regional vision is driven by claims that the government will now 'act' rather than merely 'look' east; it will accelerate the development of a number of economic corridors, BCIM (Bangladesh, China, India, Myanmar), Kaladan, and the like, to encourage development in the region. Borders, and the trade moving across them, become central to this vision of a regional economy. Therefore, while the two policies of fencing and permitting border trade may appear contradictory, they reflect the paradoxical role of borders as both opened and closed: consequently, the facilitation of movement and closure of the border are by no means as opposed as generally assumed. Here, the India-Bangladesh border demonstrates how 'in reality we have a world where the constant power and reconfiguration of fixed territories, through a system of ordering, takes place at one and the same time as the dynamics of cross-border flows and networks [which] are parallel processes and are to be found in the same time and space arenas' (Newman 2010: 775).

The region is being reconceptualized as a fluid economic space that the state nevertheless has every intention of maintaining tight control over (Uberoi 2016). The introduction of these border haats serves to symbolize the state's control of the national border in the same manner as the fence - i.e., as a body that is able to administer its territorial extent and sanction trade beyond it. While the trumpeting of these border haats is symbolically important for asserting New Delhi's control of the border, its interest in the lives of locals and desire to see regional economic development driven by trade and cross-border economic flows are claims that appeal to the centre rather than manifesting at the edges of the state.

18 In a similar fashion to the India-Myanmar border, where in 'practice, the agreement actually does not go much beyond according a formal sanction to exchanges traditionally going on between the local populations in the border areas of the two countries' (Bezbaruah 2007). This is evident in the expansion in the number and nature of items allowed to be traded at the border with Myanmar, where the items added to the list in 2012 in particular have little to do with supporting the production and traditional exchange patterns among locals, and are instead evidence of the widespread smuggling of these items being undertaken. 


\section{Localizing Border Layers}

The apparent interest of the nation-state in the welfare of the locals' lives along its borders is mediated by the state's concern with securing those same borders. Yet as the Khasi Hills Market shows, life along the borderline is not only characterized by the 'overarching security discourse' of politicians and bureaucrats, or by 'acts of resistance' to their dominance (van Schendel 2013: 267; Chapter 1). While this security discourse has created a brutal reality along sections of the India-Bangladesh border, the intersection of forest and field where unofficial border markets are held is characterized more by 'everyday life' than daily deaths. These markets are unofficial because they are officially unknown in New Delhi, but such events still occur with the connivance and under the watchful eye of the state's agents in these sensitive spaces: the patrols by members of India's Border Security Force (BSF), and later visits by the equivalent paramilitary force across the borderline, Border Guards Bangladesh (BGB), to the traders crossing the border. As such, they are not easily characterized as 'spaces of refusal' either, given that these activities are only possible with the connivance of those embodying the state at its edges.

The market therefore reflects not only the everyday life of those resident in its shadow, but also the everyday negotiations required to bring it into existence - negotiations that take in both the state's local agents and those on the other side of the borderline with whom the market is held. Research on the lives of borderlanders has often understood acts like border crossing as an example of opposition to or defiance of a central state's efforts to impose an imaginary borderline on the ground. ${ }^{19}$ This is not borne out in this instance, where attendance at such markets holds no significance, and has no connection, with the question of the legitimacy of the state's borders, any more than would one's presence at an official border haat. In conversation with villagers, most supported the fence, invoking national security arguments about migration and terrorism, regional concerns about the reservation of Meghalaya for residents, and local complaints about Bangladeshi farmers cutting their forests and stealing their crops. What locals objected to was not the fencing itself, but the way it would be implemented. ${ }^{20} \mathrm{~A}$ police sergeant

19 Although it is common to romanticize the seeming non-compliance of locals with the ordering imperatives of the centre, it is far from clear that this should be primarily understood as 'resistance'; as Karin Dean (2012:227) notes, following Nick Megoran, we should not imagine that most people are consciously attempting to subvert the state order, but merely trying to manipulate it for their own ends.

20 Duncan McDuie-Ra finds the same phenomenon, although he is keener than this study to celebrate the 'resistance' of locals to the demands of the centre (2014). 
noted how fencing would merely result in the dispossession of locals, while a village council leader of a cluster of border villages pointed to the state's insistence on construction of the fence 140 meters away from the border as the problem. Indeed, it is this issue that has previously led to protests and temporary halts to the fence's construction. ${ }^{21}$

The crucial question remaining for those in the borderlands is their ability to negotiate with the state, and this space for negotiation is circumscribed with the erection of a fence. One village headman on the border noted how he regularly crossed the border with the BSFs permission to visit relatives on the other side, but that many others did so without bothering to inform the state. It is this local agency that is threatened by the fencing; any future redefinition of informal markets as border haats would mean that they would come to be controlled by the state's agents, with the pattern visible at other haats repeated along this section of the border. At other official haats, the BSF has been accused of restricting attendance to the markets, with locals attempting to barter for access. This they frequently do through contrasting the small-scale nature of their own border trade, despite its importance to their lives, with the BSF's own involvement in, or lack of engagement with, more serious cross-border movements. Contrasting the insignificance of their exchange with the responsibilities of the BSF is a means of appealing to the sympathies of state's agents. After all, it is these large-scale movements that serve to justify the imposition of the fence upon the everyday lives of locals in the borderlands.

The general recognition of the state's boundary emphasizes the fact that negotiations enable the emergence of a space for exchange. The central governments of India and Bangladesh have presented border haats and other indications of goodwill, such as the recent enclave exchanges, as important diplomatic indications of their improved relations. For those along the border, however, it is the presence of these unofficial markets themselves which shows how locals have succeeded in negotiating the complexities of the border with which they live, overcoming periods of limited trust to re-establish the relations necessary for unofficial markets to occur. Their acceptance of the border and ability to successfully negotiate trade across these multi-layered boundaries emphasizes that it is vital for the regional development vision of the central government to involve the

21 Similarly, ongoing disputes in Tripura over the fencing of the final sections of the border centre not on the legitimacy of fence construction itself, which is constantly averred by all parties, but on the Indian government's intention to follow the terms of the 1975 agreement with Bangladesh and construct the fence 150 meters from the actual borderline. 
interests of the local people. Unless borderland zones of economic activity are incorporated into the government's plan to Act East, the state's desire to transform borders into engines of growth for the regional economy will no more resonate with locals than its insistence that unsanctioned local exchange across the border poses an existential threat to the state.

In her work on the local enforcement of national borders in the post-Soviet Fergana Valley, Madelaine Reeves cautions that what 'emerges is more complex and altogether more ambivalent' than either local acceptance of the boundary or resistance to its imposition (2011: 918). We agree in that, while the presence and location of the state's boundary have been accepted, the associated layers of institutionalized discourse within which the borders of the state are produced have not found traction among the local population. The recent emergence of the fence as a reality with which they must live does not indicate that they are any more likely to accede to the cartographic image of the borderline held in New Delhi than they have been to date. Rather, local communities will continue to respond to the reality of their circumstances. This means that while there is little active contestation of the boundary at present, the 'consensus' with regards to the India-Bangladesh border in the Northeast 'inheres in recognition of the existence of [the] border, not agreement over purpose or function' (Rumford 2012: 891).

\section{Conclusion: Layering Borders}

In recent years, a large literature has shown how spaces on the border can be characterized as fluid, shifting, and mobile places of interaction (Baud \& van Schendel 1997). In this chapter, we have emphasized border layers as the outcomes of multiscalar processes of border production. This approach is effective when examining a border like that between Northeast India and Bangladesh, as there is no real dispute over the location of the boundary line. Instead, conflict both between these states and within them stems from differing conceptions of what the borderline actually means in practice. While the fact that a market is able to be held with international boundary markers in the background may appear to suggest that this borderline has not materialized and is able to be ignored by local actors, in fact both states and their local residents have accepted the existence of the border as 'a line a priori' (Reeves 2014: 170). ${ }^{22}$ This leaves us requiring a means of

22 However, our aim has not been to examine how power is enacted through the 'reproduction of uncertainty' by the state's local agents. Reeves contrasts the deliberate uncertainty produced 
incorporating both cross-border flows and the 'hyperbolic' (Brown 2010) necessity of securing the border into an analysis that does not reduce itself to a dialectical construction of an opposition between state power and local resistance. The notion of border layers has been adopted for just this reason - to make visible the multiscalar construction of the border.

In this instance, New Delhi wishes to use border haats to speak to the state's concern with both security and development at the local, regional, and national layers. In arguing for the importance of border layers, the aim is not to draw attention to the 'nested hierarchies' at which the state operates, but rather to how the existence of the border within certain institutional and discursive spaces is able to 'jump scales' between local, regional, and (inter)national. At the border itself, the presence of a national boundary has been forcefully imposed by the Indian and Bangladeshi states, yet local communities have proven capable of negotiating these boundaries to engage with one another in spaces of exchange. Communities in the borderlands remain able to trade across these boundaries while at the same time being fully cognizant of their significance.

\section{References}

Assam Tribune (2015). Third "border haat" along India-Bangladesh frontier opens. 13 January.

Balibar, E. (2002). Politics and the Other Scene. London: Verso.

BanglaNews24 (2014). 70 border haats to be open to B'deshis. 11 October.

Baud, M. and van Schendel, W. (1997). Towards a comparative history of borderlands. Journal of World History, 8, pp. 211-242.

Bezbaruah, M. (2007). Indo-Myanmar border trade: The stakes for North East India. Dialogue, 9(1), pp.

Bhatia, R. (2016). India-Myanmar Relations: Changing Contours. New Delhi: Routledge. Bhattacharyal, A. (2015). Trading in no man's land. The Times of India. 6 September. Brown, W. (2010). Walled States, Waning Sovereignty. New York: Zone Press Cons, J. (2016). Sensitive Space:Fragmented Territory at the India-Bangladesh Border. Seattle: University of Washington Press.

by the state with the 'certainty' of the boundary line. The concern here is slightly different, in that we wish to argue that the layers within which the border exists are all ontologically grounded upon an idea of the state's borderline existing in space. The situation along the India-Bangladesh border differs from Central Asia, as locals are aware, often acutely aware, of exactly where the border is and how it relates to them. 
Das, P. (2014). Status of India's border trade: Strategic and economic significance. Institute for Defence Studies and Analyses Occasional Papers No. 37.

Dean, K. (2012). Space, territorialities and ethnography on the Thai-Sino and Indo-Myanmar boundaries. In: D. Wastl-Walter, ed., The Ashgate Companion to Border Studies. London: Ashgate Publishing, pp. 219-241.

Economic Times (2003). We extracted a lot on Sikkim, sans compromise on Tibet: Vajpayee. 24 July.

Economic Times (2011). Bangladesh \& India unveil border haat in Meghalaya'. 24July. Htwe, C. (2016). India-Myanmar border trade slumps. Myanmar Times. 28 January. Human Rights Watch (2010). Trigger Happy: Excessive Use of Force by Indian Troops at the Bangladesh Border. New York: Human Rights Watch.

Jones, R. (2012). Border Walls: Security and the War on Terror in the United States, India, and Israel. London: Zed Books.

Krishna, S. (1994). Cartographic anxiety: Mapping the body politic in India. Alternative: Global, Local, Political, 19(4), pp. 507-521.

Laine, J. (2016). The multiscalar production of borders. Geopolitics, 21(3), pp. 465-482.

Mann, M. (1984). The autonomous power of the state: Its origins, mechanisms and results. European Journal of Sociology/Archives Européennes de Sociologie, 25(2), pp. 185-213.

McDuie-Ra, D. (2014). The India-Bangladesh border fence: Narratives and political possibilities. Journal of Borderlands Studies, 29, pp. 81-94.

Meghalaya Times (2012). Tribal chiefs demand re-opening of 38 border haats in Meghalaya. 28 November.

Ministry of External Affairs (2010). Joint Communiqué issued on the occasion of the visit to India of Her Excellency Sheikh Hasina, Prime Minister of Bangladesh 12 January. [http://mea.gov.in/bilateral-documents.htm?dtl/3452/Joint+Comm uniqu+issued+on+the+occasion+of+the+visit+to+India+of+Her+Excellency+Sh eikh+Hasina+Prime+Minister+of+Bangladesh]

Nagorik Kontha (2016). More border haats on India-Bangladesh frontier soon. 26 October.

New Indian Express (2015). Modi, Hasina may jointly open 'border haat'. 28 May.

Newman, D. (2006). The lines that continue to separate us: Borders in our 'borderless' world. Progress in Human Geography, 30(2), 143-161.

Newman, D. (2010). Territory, compartments and borders: Avoiding the trap of the territorial trap. Geopolitics, 15(4), 773-778.

PMINDIA (2016). MoU between India and Bangladesh and Mode of Operation of Border Haats for setting up of Border Haats. 6 January.

Rana, K. and Uberoi, P. (2012). India's North East States, the BCIM Forum and Regional Integration. New Delhi: Institute of Chinese Studies. 
Reeves, M. (2011). Fixing the border: On the affective life of the state in southern

Kyrgyzstan. Environment and Planning D: Society and Space, 29(5), pp. 905-923. Reeves, M. (2014). Border Work: Spatial Lives of the State in Rural Central Asia. London: Cornell University Press.

Roderigues, R. (2016). Indian rule change cuts off Myanmar border trade. Nikkei Asian Review. 8 March.

Rumford, C. (2012). Towards a multiperspectival study of borders. Geopolitics, 17(4), pp. 887-902.

Sidaway, J. (2015). Mapping border studies. Geopolitics, 20(1), pp. 214-222.

Sohel, K. (2014). Four more border haats along the Indo-Bangla border soon. Dhaka Tribune. 22 July.

Sohn, C. (2016). Navigating borders' multiplicity: The critical potential of assemblage. Area, 48(2), pp. 183-189.

Sur, M. (2015). Indelible lines: Revisiting borders and partitions in modern South Asia. Mobility in History, 6(1), pp. 70-78.

Talukdar, S. (2011). India, Bangladesh revive border 'haat'. The Hindu. 23 July.

Times of India (2015). Second border haat opens in Tripura. 11 June.

Tiwary, D. (2015). BSF wants legalization of cattle trade to stop border smuggling. The Times of India. 4 June.

Uberoi, P. (2016). The BCIM economic corridor: A leap into the Unknown? In: S. Bhaumik, ed., The Agartala Doctrine: A Proactive Northeast in Indian Foreign Policy. Oxford: Oxford University Press, pp. 189-218.

van Schendel, W. (2005). The Bengal Borderland: Beyond State and Nation in South Asia. London: Anthem Press.

van Schendel, W. (2013). Making the most of 'sensitive' borders. In: D. Gellner, ed., Borderland Lives in Northern South Asia. London: Duke University Press, pp. 266-272.

van Schendel, W. and de Maaker, E. (2014). Asian borderlands: Introducing their permeability, strategic uses and meanings. Journal of Borderlands Studies, 29(1), pp. 3-9.

Wirsing, R. and Das, S. (2016). Bengal's Beleaguered Borders: Is There a Fix for the Indian Subcontinent's Transboundary Problems? Qatar: Center for International and Regional Studies, Georgetown University School of Foreign Service in Qatar. 


\section{About the Authors}

Edward Boyle is an Assistant Professor at the Faculty of Law and Centre for Asia-Pacific Future Studies, Kyushu University. He is establishing Kyushu University Border Studies (KUBS) as an interdisciplinary hub for all things border-related, and is currently examining multiscalar border effects and their implications in projects on Japan, Georgia, and Northeast India.

Mirza Zulfiqur Rahman is a Senior Research Fellow at the Department of Humanities and Social Sciences, Indian Institute of Technology, Guwahati, Assam, India. His research is on borders in Northeast India and its neighbourhood, governance, development politics, and trans-boundary water sharing and management issues between China, India, Bangladesh, and Bhutan. 



\title{
$3 \quad$ Experiencing the Border
}

\author{
The Lushai People and Transnational Space \\ Azizul Rasel
}

Jones, Reece and Ferdoush, Md. Azmeary (eds), Borders and Mobility in South Asia and Beyond. Amsterdam: Amsterdam University Press, 2018 DOI: $10.5117 / 9789462984547 / \mathrm{CHO} 3$

\begin{abstract}
This chapter investigates the neglected micronarrative of the Lushai Adivasi people living in the borderlands of Bangladesh in the Chittagong Hill Tracts, examining how they experience and deal with the new border in their everyday life. The chapter explores the broader impact of the postcolonial border on the Lushai, both direct and indirect - from psychological to political, from environmental to economic. It examines how the Lushai negotiated the newly drawn border and continued their struggle to retain their identity, arguing that the Lushai subvert the 'rigid' border in their everyday life and demonstrating that the Lushai people living on the borderland of Bangladesh and Mizoram create a Lushai unity that transcends the national borders amidst the increasing surveillance of the nation-states.
\end{abstract}

Keywords: Lushai, borders, transnational space, Chittagong Hill Tracts, Mizoram

\section{Introduction}

The making of borders in once-colonized regions like Africa and South Asia was an arbitrary and tortuous process that disregarded ethnic identities, one of the important bases of the modern nation-state (Hutchinson \& Smith 1996: 13). For this arbitrary state and border making, widespread communal riots spread both before and after the Partition of India. Thousands of people were forced to leave their ancestral places; many thousands were killed and raped (Pandey 2001; Chatterji 2007; Zamindar 2007). Apart from the immediate pitfalls of the creation of the border, Partition also ignited the seeds of future clashes, suppression, the 
marginalization of minority groups, and the further disintegration of these states.

Borderlands are one of the most fertile grounds for researching the process of border-making, cross-border mobility, and its ramifications for states and society, particularly with a focus on indigenous minority groups (eg., Cons 2012, 2013, 2014, 2016; Jones 2009a, 2009b, 2009c, 2012, 2016; van Schendel 2005; Zamindar 2007). In Border Landscapes, for example, Janet Sturgeon concentrated on the Akha in the borderlands of China and Thailand and their transformation of the border landscape (2005). In the end, she finds that in both China and Thailand the Akha were marginalized and their access to resources and land use shrank due to state policies (Sturgeon 2005:51-62). Similarly, Sara Shneiderman's ethnography of the Thangmi or Thami in the Himalayas demonstrated their circular migration between Nepal, India, and the Tibetan Autonomous Region in China (Shneiderman 2015: 98-128). As these states expanded their authority, it also resulted in the marginalization of the Thami.

This chapter investigates the neglected micro narrative of the Lushai Adivasi people living in the borderlands of Bangladesh in the Chittagong Hill Tracts (CHT) by examining how they experience and deal with the new border in their everyday life. ${ }^{1}$ This study focuses on the Lushai of Sajek Valley, on the banks of the tiny, hilly Sajek River bordering the Indian states of Mizoram and Tripura. In the next section, a brief overview of colonialism, border-making, and their general impact on the Adivasis in the CHT is provided. The third section considers the consequences of the state and the state imposed borders on the physical environment of the hills. Then the chapter investigates how the postcolonial border has impacted the Lushai people of Bangladesh. It considers how they negotiate the border in their everyday life through their understanding of their identity and through their mobility and connections to other Lushai people in the state of Mizoram in India.

1 This chapter is based on field research, mainly interviews and field observation, in the CHT and on the available primary and secondary literatures. For field research, I went to Sajek Valley, the most eastern zone of Bangladesh in Rangamati district in November 2015, February 2016, and December 2016. Any study on the Adivasi people of Bangladesh is challenging because of the lack of available sources, which can partly be explained through the disinterest of mainstream scholarship in the study of Adivasi society. The conventional archives possess very few records on them; national newspapers, magazines, and journals rarely run news concerning Adivasi issues. Another impediment in researching the Adivasi people in this area is the difficulty of carrying out field studies. The area is still a conflict zone and is tightly controlled by state machinery. Researchers and humanitarian activists are highly monitored by the state security intelligence. I was even interrogated by the army while conducting this field study. 
Figure 3.1 The Chittagong Hill Tracts

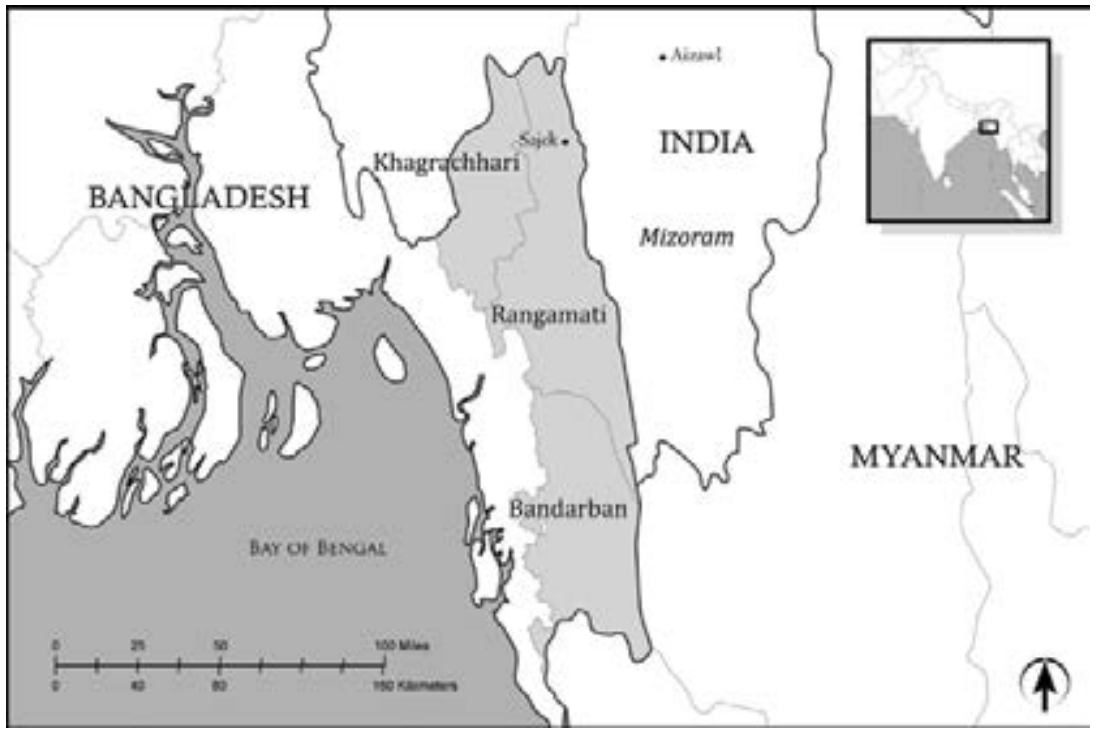

\section{The Colonial and Partition History of the Chittagong Hill Tracks}

While the hill districts have little geographical congruence with the plains of Bengal, they have remarkable resemblance with Myanmar and the Indian states of Assam, Tripura, and Mizoram. The hill region of Bangladesh, now known as the Chittagong Hill Tracts, was depicted on the earliest known map of Bengal drawn by Joao Baptista Lavanha c.1550. During that time, the area was not named the Chittagong Hill Tracts but was part of the larger hilly terrain connecting India with Burma. After entering the area by 1860 , the British named it the Chittagong Hill Tracts (van Schendel, Mey, \& Dewan 2001: 19). This name suggests that the British understood the hills as an extension of the low lands of Chittagong of Eastern Bengal. Similarly, they treated the hills adjacent to Arakan as an extension of the lowland of Arakan and named them the Arakan Hill Tracts, and the hills adjacent to Tripura the Hill Tippera (van Schendel, Mey, \& Dewan2oo1: 19). The British brought the CHT - i.e., all the land to the west of the North Lushai Hills, South Lushai Hills, and Arakan Hills - under the purview of the Bengal Province.

The Lushai are one of the marginalized groups in present-day Bangladesh and are now the smallest among the twelve major ethnic groups in the CHT (Kamal, Islam, \& Chakma 2007: 108). They have a distinct culture, 
language, traditions, customs, and values. Lushai living in the Sajek Valley claim that they settled there before the British colonization of India. ${ }^{2}$ It is generally accepted by the community that Lushai people first migrated to Burma from Chinlung in China, and that their ancestors were Mongolians. The local tradition states that the Chinese king left China because of a disagreement with his father and headed to Burma, present-day Myanmar. Upon his arrival in Burma, he founded a village called Oxatlung. The king's descendant, Jamukha, ruled there for a long time. In the course of time Jamukha's successors expanded their rule into the Chin Hills, Manipur, Kachar, Mizoram, and Satkang (Chittagong), and continued their rule for more than two hundred years (Kamal, Islam, \& Chakma 2007: 108). ${ }^{3}$ The Lushai migrated to Manipur, the Lushai Hills, and the surrounding areas between 1463 and 1466 (Vumson 1986: 58-59). From there they spread over the hill regions that are now districts in Chittagong division.

Some scholars think that the word Lushai originated from the two words Lu ('head') and shei ('long') (Kamal, Islam, \& Chakma 2007: 108). It is thought that the Lushai had the tradition of growing long hair, which made them look like long-headed (Kamal, Islam, \& Chakma 2007: 108). Vumson thinks the original name 'Lushei' was distorted in the narrative and records of British colonial administrators into 'Lushai'. By 'Lushai' or 'Lushei', the British meant all of the Zo clans living in Mizoram(Vumson 1986: ${ }_{5}^{6}$ ). The British used several spellings for the Lushai, such as 'Lushai', 'Lushei', and 'Lhoosai' (Lewin 1869).

In the 186os, Captain T.H. Lewin, the British colonial Deputy Commissioner of the area, wrote:

The Lhoosai, commonly called the Kookies, are a powerful and independent people, who touch upon the borders of the Chittagong Hill Tracts. They extend in numberless hordes, north and north-east, until they reach Cachar on the one hand, and the frontiers of Burmah on the other. They cannot be considered as a nation, for they have no coherence of government or policy, but, with slight differences, they speak one language and follow the same customs. They are known to the Bengallees by the name of Kookie, and to the Burmese as the Lankhe. Our knowledge of the Lhoosai clans is of course confined to the tribes on our immediate frontier, with whom we have been brought into contact (Lewin 1869: 98).

2 Interview with a retired school teacher, Lamthimkima Lushai, 19 February 2016, Sajek Valley.

3 However, according to Lewin, 'They differ entirely from the other hill tribes of Burman or Arakanese origin, in that their faces bear no marks of Tartar or Mongolian descent' (1869: 103). 
From Lewin's account it is apparent that the Lushai were a prominent group during the colonial period. However, Lewin showed a disinclination to give Lushai the status of a nation. For him, the Lushai did not have 'coherence in government and policy'.

Colonialism had a significant impact on the Lushai and other Adivasi groups of the CHT and there was large-scale disruption in their ways of life. The colonizers restricted natives' rights to land and free movement. The British imposed a ban on the carrying of indigenous weapons - which had been a key part of Adivasis' lifestyle, and were used for hunting and personal safety. Colonialism also seriously impeded the jhum (shifting or slash-and-burn) cultivation practiced by Adivasi peoples, which was once their principle livelihood and is the most viable cultivation method in the hilly area. The colonial administration started to regulate the resources of the CHT and undermined hereditary political institutions and customary ownership of land. The Forestry Act was one of the most exploitive, which heavily impacted and marginalized Adivasi people in the CHT by preventing them from entering newly reserved forests. This hindered their ability to hunt, fish, graze domesticated animals, and even cut bamboo for building materials (Muriel 1939: 5, 19).

However, the most impactful event for the Adivasis of the CHT was the imposition of a border through the region. The creation of borders in South Asia was an arbitrary and convoluted process; the colonial government was indecisive about whether to Partition India until June 1947 - only a month and half before the British rule ended in the subcontinent. In that month, the Governor General declared the formation of two Boundary Commissions, one for the Punjab and the other for Bengal. The Bengal Boundary Commission was given the authority to draw the Bengal borderline. Sir Cyril Radcliffe was the chairman of both Commissions and was given only six weeks to sketch the boundary (van Schendel 2005: 39). However, he was not familiar with the area and there also were various interest groups and lobbyists trying to influence the Commission. While drawing the border between India and Pakistan, the boundary Commission was obsessed with the Muslim-Hindu binary and disregarded other ethnic minorities and religious groups (van Schendel 2005: 39). The Chairman and members of the Boundary Commission did not give much thought to Adivasi people, who were neither Muslims nor Hindus, but mostly Buddhists, Christians, or animists. Three chiefs of different ethnic groups in the CHT met with the members of the Boundary Commission during this time and demanded that the CHT be given independence. If that was not possible, their second choice was to be included in India (Roy 2000: 45-46). To the surprise and 
dismay of many, the CHT was awarded to Pakistan, the Arakan Hill Tracts to Burma, and Hill Tippera and the Lushai Hills (present-day Mizoram) was given to India (van Schendel \& Dewan 2001: 20).

The Partition of 1947 separated different Lushai communities with an international border, and many were reluctant to remain in Pakistan. ${ }^{4}$ After the Partition, many Lushai from the CHT migrated to Mizoram. The 1951 Population Census shows around 3351 Lushai residing in East Pakistan (which became Bangladesh in 1971), but by the 1991 Bangladesh Census that number was only 66 (Vumson 1986: 315; Kamal, Islam, \& Chakma 2007:108). ${ }^{5}$ Unfortunately, the two most recent Bangladesh Censuses do not provide detailed information about the ethnic composition in the CHT.

Thus, from a dominant ethnic group the Lushai have dwindled and become the most marginalized group in the CHT. All of the major ethnic groups in the CHT, for example, the Chakma, Marma, Tripura, and Bawm, have their own political associations through which they advocate for their rights. These groups have representation in the local boards and councils of the CHT districts. More importantly, the entire CHT is divided into three administrative circles: the Chakma Circle, Bawmang Circle, and Mong Circle. In these circles, the highest position is raja, followed by headman, and karbari. The Lushai fall under the jurisdiction of the Bawmang Circle. However, no Lushai could ever become a raja (a 'king'); ${ }^{6}$ they are only represented as headmen and karbari ('business person'). 7 Their political disempowerment has contributed to the challenges facing the Lushai in other sectors such as health, education, jobs, and overall living standards. Consequently, even the Lushai who remain in Bangladesh are considering migrating to Mizoram to join their families that are already there.

\section{The Impact of Borders and the State on the Environment}

On a chilly winter evening of 8 December 2016, when the entire valley was covered with fog and clouds, I had a friendly and vibrant chat with Lalthanga and a few other Lushai. Lalthanga Lushai is the headman of the Lushai community in Ruilui Para of Sajek Valley. He was surrounded by six

4 Interview with Lalthimkima Lushai, 19 February 2016.

5 The 1951 number includes Lushai and Kukis. Kukis and Lushai were considered to be the same ethnic group by the British administrator of the Hill Tracts. Some scholars think Kukis are clan of Lushai people (Shakespear 1912).

6 Interview with Lalthanga Lushai, 8 December 2016.

7 Interview with Lalthanga Lushai, 9 December 2016. 
to eight people from his community for an evening chat. I entered in the middle of their conversation, introduced myself, and talked about my project. Lalthanga showed interest in my research and agreed to participate. We started our conversation about the weather and the scenic natural beauty of the valley, where tourists from Dhaka come to take in the clean air and mountain views. The headman appreciated my compliments about the beauty but said that the environment and natural beauty had been 100 times better during the British colonial period. He said that in the past there had been dense forest all around, and animals like tigers, elephants, deer, wild pigs, and snakes were common. The headman said that these wild animals had roamed the area as late as the 1970s, when people would not dare to venture out alone at night. However, over the past forty years, the dense forests have declined rapidly and except for a few hens, pigs, and deer, most of the wild animals and birds are now lost from the area. ${ }^{8}$

The environment of the CHT began to change with the colonial intervention into the area. The British introduced the idea of conserving the forest and animals through the creation of reserves, which resulted in restrictions on the movement and settlement of Adivasi communities. With the new border and the emergence of Pakistan in 1947 the restrictions became greater, and expanded further after the creation of Bangladesh in 1971. The new state acquired more land for the reserve forest and military bases in the area (IWGIA 2012: 22, 30-33). Reece Jones has argued that the adoption of common land as private property can have detrimental impacts on the land and environment because it confers on the individual the total right to exploit the land. He argues that private property and state control open the opportunity for capitalist exploitation of the land (Jones 2016: 87-88).

Although the British did make a few changes to customary land rights in the CHT, massive changes have taken place after the emergence of Pakistan in 1947 and the birth of Bangladesh in 1971. In the CHT, there had been no individual ownership of land, but the Bangladeshi state has disregarded Adivasi forms of customary land ownership and has been trying to impose individual land ownership on the area. In 1979, the state also started a project of encouraging the mass migration of lowland Bengali people into the CHT. Between 1979 and 1984, thousands of landless poor non-Adivasis settled there. This mass migration was patronized by the government, which provided logistical support in the form of rations, money, ploughs, and cows (Roy 2000: 107). The growing population and lack of local environmental knowledge led to the over-exploitation of the land and environment. Previously, the CHT 
Lushai people were mainly involved in agriculture. ${ }^{9}$ They would earn their livelihood through jhum cultivation and hunting wild animals. However, increasing population pressure in the CHT and state exploitation of Adivasi land placed pressure on agricultural land. Excessive cultivation of the same jhum plots decreased their agricultural productivity. The Lushai in the Sajek Valley used to have very good orange groves, but most of the orange groves are now dying from malnutrition because of the new aridity of the land. ${ }^{10}$

Consequently, the economy of the Lushai people has gradually transformed from agriculture to tourism. The Sajek Valley is one of the most remote places in Bangladesh; the area was not connected with the cities of Rangamati or Khagrachhari by road until the Bangladesh Army began to construct one in 2010, which finally connected the valley with the other hill districts in 2013. After the construction of this road, the valley has been developed into a popular tourist spot. There is an increasing tendency to construct tourist lodges in the valley. The Bangladesh army has already constructed two concrete tourist lodges; my field research found that current and retired army officers are investing money to construct tourist lodges as joint ventures between the army officers and the Lushai living in the valley. ${ }^{11}$ Lalthanga Lushai estimated that around 50,00o people visit Sajek every year. ${ }^{12}$ This excessive number of people has a negative impact on the environment of the area; the valley is already experiencing a water crisis that is particularly severe during the cold season.

The Lushai in the valley are now mainly dependent on income from tourism. For example, Laldova Lushai has two houses to rent to the tourists, and he and his wife also cook for the tourists. If for any reason, for example conflict, fewer or no tourists were to visit the valley, they would be in a very precarious situation. When I visited the valley in February 2016, for example, there was a conflict between the Adivasis and the Bengalis that affected tourism in the Sajek Valley. The tourists who did come to visit the valley quickly left, and for the next few months the Lushai hosted very few tourists. This overdependence on tourism has led them into perpetual food insecurity.

9 Interview with Lalthimkima Lushai, 19 February 2016.

10 Interview with Lalthanga Lushai, 9 December 2016.

11 Interview with David Lushai, 9 December 2016.

12 Interview with Lalthanga Lushai, 8 December 2016. It was not possible to corroborate the information with other sources. The army keeps records of the number of tourists who come to the area, but they do not share information outside their organization. However, Lalthanga Lushai's estimate seems plausible. He mentioned that Ruilui Para has the capacity to accommodate 500-550 tourists, Konglak Para can accommodate 100-150, and the Bangladesh army has constructed two luxurious resorts that can accommodate 20-25 tourists in total. 
Figure 3.2 The Sajek Valley

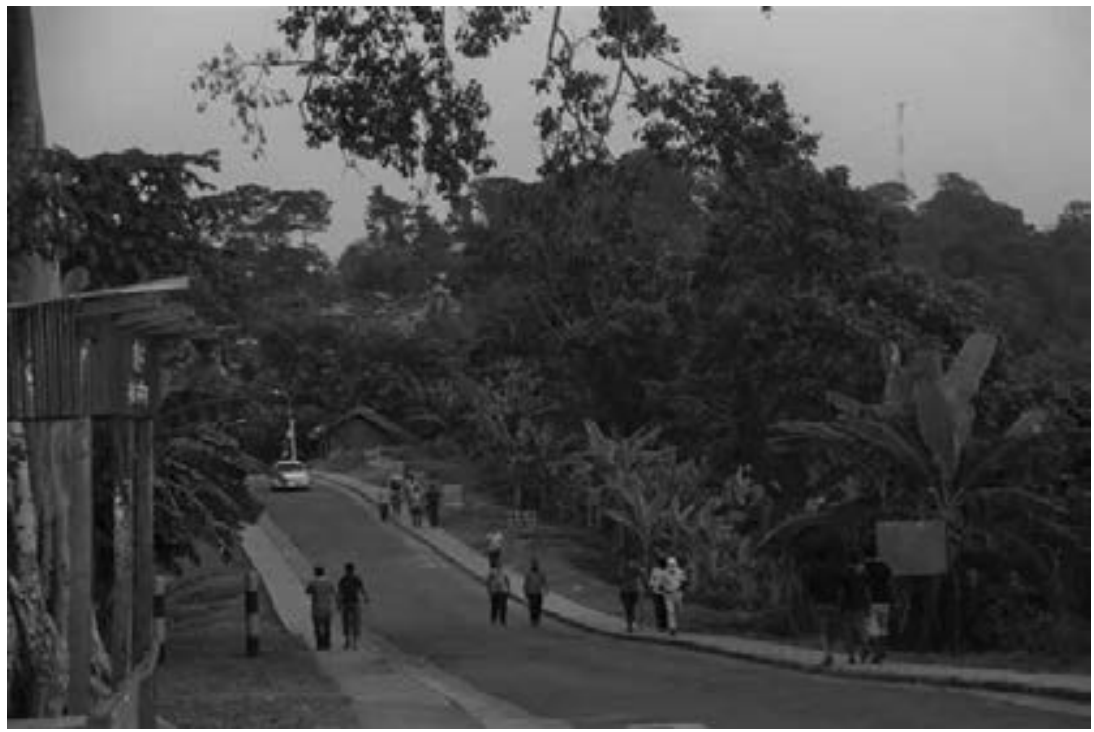

The construction of the Kaptai Hydroelectric Dam in 1962 also impacted the environment of the CHT, both directly and indirectly (Bari 2012: 313-314). The dam submerged 54,000 acres of agricultural lands in the CHT, and it is thought that these agricultural lands were the most fertile in the area (Roy 2000: 95-100). It displaced more than 100,000 people, who were not properly rehabilitated: the total amount of submerged land was 54,000 acres, but only 20,000 acres of alternative land were allocated to the affected people (Roy 2000: 95-100). Moreover, most of the land allocated was unsuitable for cultivation. In addition, 8000 Adivasi people did not receive any land, because the government did not recognize their customary land rights. After the construction of the dam, many Chakma were relocated to the Marishya and Baghachhari areas, adjacent to the Sajek Valley (Adnan 2004: 46), and many settled in the valley itself, creating additional pressure on the land. ${ }^{13}$ This led to the over-exploitation and consequent degradation of the soil and environment.

Another development in the postcolonial state that affected the environment of the CHT, and the Sajek Valley in particular, was the founding of state factories. One such factory is Karnafuli Paper Mills (KPM), established in 1951 by the Pakistani Industrial Development Corporation. The KPM was 
taken under the control of Bangladesh Industrial Development Corporation after the 1971 Bangladesh Liberation War. This mill mainly extracts raw materials (wood and bamboo) from the CHT (Habibullah 2012: 212-214). To collect these raw materials, the state constructed massive roads; and cars and giant trucks ply these roads, disturbing the wild animals living in the area. One of the main reasons for the extinction of the wild animals referenced by the Lushai headman is the interruptions caused by the KPM's cars and trucks and the destruction of the forest. ${ }^{14}$

The final way the border impacts the environment of the Sajek Valley and the CHT is through border fencing, which has created an impediment for the migration of wild animals. Lathanga, Laldova, and David Lushai reported that there was no fencing on the border in the initial years after Partition, but recently they have observed that India has been constructing fences. ${ }^{15}$ All of these environmental changes have a direct or indirect connection with the border. The Adivasi, particularly the Lushai, are not involved in policymaking and are not empowered to regulate their own resources. Thus, when the state undertakes policies and projects in the CHT, it does not consider the probable environmental or other consequences in the area, or the connections of the local population with the land or with people who are now on the other side of the border.

\section{Lushai Mobility, Identity, and Transnational Space}

Borders create a physical and psychological separation among humans: physical, by restricting the movement of people and animals through international immigration laws, regulations, and border fencing; mental, by creating a sense of separation through the idea of the modern state, national identity, and sovereignty. In this section, I investigate how the Lushai people of Bangladesh responded to the implementation of the border. Although they had to take on the official national identity of Pakistani and later Bangladeshi, did the border really create a disconnect between them and their counterparts living in Mizoram? If not, how do they maintain connections with those living on the other side of the border? Do they attempt to create a Mizo or Lushai unity or 'nationhood', transcending the national border and identity?

14 Interview with Lalthanga Lushai, 8 December 2016.

15 Interview with Lalthanga Lushai, 8 December 2016, Laldova Lushai 9 December 2016, and David Lushai, 9 December 2016 . 
Bangladesh shares a $4096 \mathrm{~km}$ border with India, of which Bangladesh and Mizoram share $318 \mathrm{~km}$ (Border Management Division n.d.). It is clear that the new international border disrupted the movement of the Lushai population in both Bangladesh and Mizoram (India). Many Lushai migrated during the years following the creation of the border. Thus, the number of Lushai population in the CHT decreased significantly after the Partition in 1947. Lalthimkima Lushai was one of the few Lushai who did not migrate from Bangladesh. His father was in the police service and was posted in Rangamati before the Partition. He did not opt to change his posting after Partition and remained in East Pakistan (now Bangladesh). After retiring from the job, his father and family settled in the Sajek Valley, which was very densely forested and remote at that time. During Partition, Lalthimkima was just sixteen-years-old. He grew up in that remote village and luckily got a job as a primary school teacher in the nearby Marishya Valley, another hilly region like Sajek. For the last few years before retirement, he was posted in a primary school in his area, in Ruilui Para, Sajek Valley. Although he stays in Bangladesh, many of his relatives, including his son, have migrated to Mizoram. His elder son is well-settled there and has received Indian citizenship. His grandchildren from his elder son are studying in Aizawl, the capital of Mizoram. His younger son died recently and his daughter-in-law also moved to Aizawl, but later came back to Sajek to earn money to pay for her children's education in Aizawl. ${ }^{16}$

Lushai people migrated from Bangladesh in three main phases. The first massive migration occurred right after Partition, when Mizoram was added to Assam in India. The second phase was after 1972, when Mizoram was declared a Union Territory, and the third phase was after the end of the long Mizo nationalist movement through which Mizoram received the status of Federal State of Indian Union in 1986 (van Schendel 2015). A similar uprising occurred in the CHT in Bangladesh, and in response the Bangladeshi state deployed security and law enforcement agencies throughout the region. The state has virtually made the whole area a cantonment: approximately one third of the Bangladeshi army is posted in the CHT, around 35,000-40,000 soldiers. In addition to this, a number of other armed forces are deployed in the area. Among these forces are 10,000 BGB (Border Guards Bangladesh) personnel and 10,000 Ansars ('paramilitary forces'), which makes the total number 50,000-60,000 (IWGIA 2012:12). In the Sajek Valley, there is a large army camp and a BGB camp. There are two more army camps within few kilometres of the Sajek Valley, in Machlang and Baghaichhari. Saimon 
Lushai said that there was widespread surveillance and distrust of the Lushai during the Mizo nationalist movement. ${ }^{17}$

When asked about the reasons for migration to India, most of the Lushai were initially hesitant to respond. However, after a while they started to talk. One of the main reasons, they pointed out, is that they regard Aizawl as their cultural and spiritual centre. Further, Mizoram offers opportunities and scope that are not available to them in Bangladesh. As the most marginalized ethnic group in the CHT, Lushai's status and opportunities are minimal. Most of the Lushai in Bangladesh are concentrated in the Sajek Valley, where there is only poor access to education, healthcare, and jobs. There is one primary school in Ruilui Para and another at Kanglak, and a middle school at Ruilui Para where students are enrolled up to the eighth grade. For secondary and higher secondary education, they need to travel many miles of thorny mountain roads to the adjacent district of Khagrachhari or take a boat to Rangamati - a journey that takes almost an entire day. Accessing a university education in Bangladesh is often beyond their dreams. Another important reason for migration is their state-sponsored suppression. Like other ethnic groups in the CHT, they face attacks from the Bengali settlers. One such incident occurred in 2008, when the settler Bengalis launched a massive attack against the Lushai in the Sajek valley. The settler Bengalis burnt more than 78 houses and killed one person; the army was also allegedly involved in this attack on the side of the Bengali settlers (IWGIA 2012: 27).

Although the new international border impeded their movement, the border has never been insurmountable for the Lushai. Lalthimkima, Saimon, and Lalthanga Lushai, the headmen of the Lushai community in the Sajek Valley, reported that the border was comparatively porous in the initial years of its creation. They did not even have a sense of the border at first. ${ }^{18}$ However, with the outbreak of the Mizo nationalist rebellion in 1966, it became more difficult to cross. The army headquarters of the Mizo Nationalist Front (MNF) was located in the Sajek Valley, and the rebels were spread across the CHT. The then-Pakistani state was cautious and remained vigilant toward the Lushai living in the CHT; ${ }^{19}$ Bangladesh followed the same policy until 1986 , when the MNF reached an agreement with the Indian government and Mizoram was declared a state. Many Lushai in this area were detained by India during the Mizo war, allegedly for supporting the Mizo rebels. ${ }^{20}$ 
The Lushai of the Sajek Valley make frequent visits to Aizawl. It takes three to four hours of walking along the hilly roads through the jungles and across the shallow and narrow Sajek River to reach the border village of Silsuri in Mizoram. From there, it is another eight to ten hours by bus to reach Aizawl. They usually start their journey to Aizawl early in the morning, and it takes the whole day to reach there. When asked about the legality and possibility of any harassment in this journey, the Lushai thought the question of legality was irrelevant; they believe they should have the right to visit the other people from their ethnic group on the other side of the border. ${ }^{21}$ They told me that except for during the Mizo rebellion, they have never faced much difficulty in crossing the border. If sometimes they do face legal action, other members of their ethnic group in Mizoram come to help them. This is particularly significant because most positions in the higher echelons of the government in Mizoram are currently held by Lushai people.

However, the border has become stricter over the past few years. After the 1 July 2016 terrorist attack in Dhaka, in which twenty people were killed at a restaurant, India tightened security in the border (BBC News 2016). This has sometimes created difficulty for the cross-border movement of the Lushai people. In September 2016, Laldova Lushai went to visit his relatives in Aizawl as usual, but some Chakmas from the Silsuri village of Mizoram informed the BSF that he had crossed the border. He was arrested on suspicion of terrorist infiltration and held in BSF custody for about a month. During this time, Laldova was routinely beaten, even though he tried to tell the BSF that he was not a terrorist and was only going to Aizawl to visit his relatives. He was freed after a month due to a request from one of his relatives who works in the police department in Aizawl. ${ }^{22}$ By contrast, the Lushai face almost no difficulty from Border Guard Bangladesh (BGB) when they cross the border. The headman and others informed me that the army and BGB are well aware of their movements and do not interfere. ${ }^{23}$ Indeed, the Lushai now have better relations with the army and BGB than do other ethnic groups in the CHT.

Some Lushai from Bangladesh exhibit a pattern of circular migration across the border. Some Lushai migrate to Mizoram and settle there for many years, but come back to Bangladesh after a decade or more. After living for a few years in Bangladesh, they again go back to Mizoram. Some are even citizens of both Bangladesh and India. I was able to interview one

23 Interview with Lathanga Lushai 8 December 2016, Laldova Lushai 9 December 2016, David Lushai, 9 December 2016, Daniel Lushai 9 December 2016, and Saimon Lushai, 9 December 2016. 
such individual, Saimon Lushai. His extended family still live in the Kanglak Para of Sajek Valley, but he migrated to Aizawl in 1986. He lived there for six years and then came back to Bangladesh in 1993; he lived there until 1997, and then again went back to India. When I interviewed him in December 2016, he had been visiting his extended family in Bangladesh since August and planned to re-join his family in Aizawl in the New Year. ${ }^{24}$

\section{Conclusion}

The dominant nationalist discourses of South Asia have long marginalized the history of minority ethnic groups. This chapter has explored the broader impact of the postcolonial border on the Lushai, both direct and indirect - from psychological to political, environmental to economic. The chapter also examined how the Lushai negotiated the newly drawn border and continued their struggle to retain their identity. I argue that the Lushai subvert the 'rigid' border in their everyday life and demonstrate that the Lushai people living on the borderland of Bangladesh and Mizoram create a Lushai unity that transcends the national border, even amidst the increasing surveillance of the nation-states.

The Lushai of the CHT create a transnational space from below through their activities and cross-border mobility. Transnationalism can be explained as the mobility of people, capital, power, and information across borders; it also means the reconstitution of a society or group of people (Ley 2004: 156). Most of the Lushai families in Bangladesh maintain transnational family ties. David Lushai said that there is a tendency among the Lushai of the Sajek Valley to arrange a marriage for their son or daughter in Mizoram and thus retain or create strong ties with the Lushai living in Mizoram. David recently turned 38 and his father Lalthimkima Lushai and elder brothers are desperately seeking a bride for him. His father's preference is for a bride from Mizoram. ${ }^{25}$ Transnational family ties also help them cross the international border with ease. The Lushai of the CHT create a transnational space through cultural festivities, traditional clothing, buying books about Lushai history that are published in Mizoram, preparing traditional foods that are popular in Mizoram, watching Mizo television channels, listening to Mizo radio programmes, and singing traditional Lushai songs. They also use the same Mizo calendar as their counterparts across the border. 
Lushai people from Bangladesh visit Mizoram for diverse purposes: education, medication, work opportunities, cultural festivals, and seeing their extended families. Almost all of the Lushai I interviewed let their children go to Aizawl for their undergraduate and graduate studies. For example, the headman Lalthanga Lushai has four children, two of whom are currently attending colleges in Mizoram. His daughter, Helen Thanga Nuri, has recently finished her M.S. degree in Mizoram and his son Buanga is studying for an undergraduate degree in Business Administration. ${ }^{26}$

Not only do the Lushai of the CHT visit Mizoram, but their relatives from Mizoram also occasionally visit Bangladesh to meet their extended families. Lalthanga Lushai proudly told the author that when a Mizo minister visited Bangladesh, he had come to visit them. Lalthanga and all of the Lushai people I talked with in the Sajek Valley seemed to feel very proud of Aizawl. ${ }^{27}$ When the Mizo nationalist revolt started in the 196os they were emotionally connected to the movement and supported it wholeheartedly. The Lushai of Bangladesh see the Lushai of Mizoram as their true community. ${ }^{28}$ The Lushai living in the borderlands of Bangladesh and Mizoram create a complex Lushai identity that transcends the border and the imposed postcolonial national identity.

\section{References}

Adnan, S. (2004). Migration, Land Alienation and Ethnic Conflict: Causes of Poverty in the Chittagong Hill Tracts of Bangladesh. Dhaka: Research \& Advisory Services. Bari, F. (2012). Kaptai Dam. In: Banglapedia: National Encyclopedia of Bangladesh, vol. 4, 2nd ed. Dhaka: Asiatic Society of Bangladesh.

BBC (2016). Bangladesh siege: Twenty killed at Holey Artisan Bakery in Dhaka. [Online]. BBC News.Available at: http://www.bbc.com/news/world-asia-36692613 Border Management Division, Ministry of Home Affairs, Government of India (n.d). Management of Indo-Bangladesh Border. [Online]. New Delhi: MOHAGOI. Available at: http://mha.nic.in/sites/upload_files/mha/files/BM_MAN-INBANG-270813.pdf

Chatterji, J. (2007). The Spoils of Partition: Bengal and India 1947-1967. Cambridge: Cambridge University Press. 
Cons, J. (2012). Histories of belonging(s): Narrating territory, possession, and dispossession at the India-Bangladesh border. Modern Asian Studies, 46, pp. 527-558.

Cons, J. (2013). Narrating boundaries: Framing and contesting suffering, community, and belonging along the India Bangladesh border. Political Geography, 35, pp. 37-46.

Cons, J. (2014). A View from the India-Bangladesh border. [Online] East Asia Forum, 6(1). Available at: http://www.eastasiaforum.org/2014/04/o8/a-view-from-theindia-bangladesh-border/

Cons, J. (2016). Sensitive Space: Fragmented Territory at the India-Bangladesh Border. Seattle: University of Washington Press.

Habibullah, M. (2012). Karnafuli Paper Mills. In Banglapedia: National Encyclopedia of Bangladesh, vol. 8, 2nd ed. Dhaka: Asiatic Society of Bangladesh.

Hutchinson, J. and Smith, A., eds. (1996). Ethnicity. Oxford: Oxford University Press. IWGIA (2012). Militarization in the Chittagong Hill Tracts Bangladesh: The Slow Demise of the Region's Indigenous People. Copenhagen: IWGIA.

Jones, R. (2009a). Geopolitical boundary narratives, the global war on terror and border fencing in India. Transactions of the Institute of British Geographers,34, pp. 290-304.

Jones, R. (2009b). Agents of exception: border security and the marginalization of Muslims in India. Environment and Planning D: Society and Space, 27, pp. 879-897. Jones, R. (2009c). Sovereignty and statelessness in the border enclaves of India and Bangladesh. Political Geography, 28(6), pp. 373-381.

Jones, R. (2012). Border Walls: Security and the War on Terror in the United States, India, and Israel. London: Zed Books.

Jones, R. (2016). Violent Borders: Refugees and the Right to Move. New York: Verso. Kamal, M., Islam, Z., and Chakma, S., eds. (2007). Indigenous Communities. Dhaka: Asiatic Society of Bangladesh.

Lewin, T.H. (1869). Hill Tracts of Chittagong and Dwellers Therein: With Comparative Vocabularies of the Hill Dialects. Calcutta: Bengal Printing Company Limited.

Ley, D. (2004). Transnational spaces and everyday lives. Transactions of the Institute of British Geographers, 29(2), pp.151-64.

Muriel, C.E. (1939). The Bengal Presidency Forest Manual: Notifications Under the Indian Forest Act and Other Orders Affecting the Public. Alipore: Bengal Government Press.

Pandey, G. (2001). Remembering Partition: Violence, Nationalism and History of India. Cambridge: Cambridge University Press.

Roy, R. (2000). Land Rights of the Indigenous Peoples of the Chittagong Hill Tracts, Bangladesh. Copenhagen: IWGIA.

Shakespear, J. (1912). The Lushei Kuki Clans. London: MacMillan. 
Shneiderman, S. (2015). Rituals of Ethnicity: Thangmi Identities Between Nepal and India. Philadelphia: University of Pennsylvania Press.

Sturgeon, C.J. (2005). Border Landscapes: The Politics of Akha Land Use in China and Thailand. Seattle: University of Washington Press.

van Schendel, W. (2001). Who speaks for the nation? Nationalist rhetoric and the challenge of cultural pluralism in Bangladesh. In:W. van Schendel and E.Zürcher, eds., Identity Politics in Central Asia and the Muslim world: Nationalism, Ethnicity, and Labour in the Twentieth Century. New York: I.B. Tauris Publishers.pp. 107-48. van Schendel, W. (2005). The Bengal Borderland:Beyond State and Nation in South Asia. London: Anthem Press.

van Schendel, W. (2015). A war within a war: Mizo rebels and the Bangladesh liberation struggle. Modern Asian Studies, 1-43.

van Schendel, W., Mey, Q., and Dewan, A. (2001). The Chittagong Hill Tracts: Living in a Borderland. Dhaka: The University Press Limited.

Vumson (1986). Zo History: With an Introduction to Zo Culture, Economy, Religion and Their Status as an Ethnic Minority in India, Burma, and Bangladesh. Aizawl: Vumson.

Zamindar, V. (2007). The Long Partition and the Making of Modern South Asia: Refugees, Boundaries, Histories. New York: Columbia University Press.

\section{About the Author}

Azizul Rasel is a historian, Lecturer, and Research Associate at the Center for Advanced Theory, University of Liberal Arts Bangladesh. He completed master degrees in history from the University of Dhaka, Bangladesh and Leiden University, the Netherlands. His fields of interest include early modern and contemporary South Asian history, society, and culture. 



\section{Section II}

Mobility in and Beyond South Asia 



\title{
4 Of Insiders, Outsiders, and Infiltrators
}

\author{
The Politics of Citizenship and Inclusion in Contemporary \\ South Asia
}

Kavitha Rajagopalan

Jones, Reece and Ferdoush, Md. Azmeary (eds), Borders and Mobility in South Asia and Beyond. Amsterdam: Amsterdam University Press, 2018 DOI: $10.5117 / 9789462984547 / \mathrm{CHO} 4$

\begin{abstract}
South Asia serves as a unique site of inquiry for understanding the complexities surrounding citizenship and belonging today. South Asia's already complex migration landscape is further complicated by rapid urbanization, political Islamophobia, and inadequate policies on migration and citizenship. Nowhere is this complexity thrown into sharper focus than the porous borderland where India, Bangladesh, Myanmar, and Nepal meet, where refugees and stateless persons from Nepal and Bhutan regularly join economic migrants from Bangladesh and newer refugee streams from Myanmar. They move with relative freedom across unguarded swathes of terrain, into Indian tribal and urban ethnic Bengali communities that are targets of Islamophobic rhetoric and communal violence. The unresolved histories of shifting borders have led to decades-long territorial disputes and depatriated populations in this region, and most South Asian countries lack opportunities for long-term and permanent legal migration. This chapter explores the emerging migration realities in the northeastern corner of South Asia as a case study of unauthorized migration in regions with limited-to-no migration management infrastructure. Ultimately, the chapter considers what citizenship and belonging mean in a global era.
\end{abstract}

Keywords: citizenship, refugees, Myanmar, Bhutan, India, globalization 


\section{Introduction: South Asia in an Age of Global Migration}

Shyam Rai entered Nepal on the flatbed of an Indian lorry when he was four years old. ${ }^{1}$ He was hemmed in on all sides by a sweating forest of knees and thighs, one among the estimated 90,00o people who were expelled from the Kingdom of Bhutan over the course of half a dozen years in the early 1990s. Stripped of their Bhutanese citizenship in 1989, coerced or tortured into conceding to 'voluntary emigration', the Nepali-speaking Hindu people known as the Lhotshampa ('southerners') to the Buddhist Bhutanese, crossed into India as refugees, the women smuggling Bhutanese passports in their bras in the hope of reconciliation and a return home. India then deployed its army to the border under strict orders to remove the refugees, which they did by piling them into Tata trucks without medicine or provisions, let alone seating and safety belts, and driving them to the Mechi River that divides India from neighbouring Nepal. There, they herded them across the watery border and left them stranded on the opposite riverbank. For months, while they waited for distant powers to sort out their fate, the Lhotshampa camped in the open air in the jungle beside the riverbank, plagued with hunger and disease. Rai describes a ghastly scene, calling forth the disconnected images and eerie sounds characteristic of traumatized early memory, as he speaks of babies dying all around him of cholera, their cries haunting the unlit night.

For nearly three decades, the Lhotshampa hung in limbo in refugee camps, sometimes leaving to work as undocumented seasonal migrants in cities in Nepal and neighbouring India. Eventually the majority were resettled as refugees, primarily in the United States, but also in Canada, Australia, New Zealand, Norway, the Netherlands, Denmark, and the United Kingdom. Some still hold out hope for a return to Bhutan, a country that does not want them back, while some wish to claim Nepal as their home, even if it refuses to accept them. Others still decouple their sense of nationhood and homeland from any physical geography or paper citizenship. In a sense, the Lhotshampa are a people created more through their rejection by different dominant groups than by their own volition, who are perceived as migrants even

1 Opening this chapter and woven throughout is the story of Shyam Rai, a Lhotshampa ('Bhutanese Nepali') and resettled refugee that I interviewed in his home in Utica, New York in January 2015, as part of my research on Rust Belt and post-industrial cities in the US seeking to repopulate and revitalize themselves by attracting and retaining different categories of migrants. Utica 'specialized' in refugees. I have also included some of my observations from a site study of citizenship and belonging I participated in with a research team from the Carnegie Council for Ethics in International Affairs in Myanmar in June 2015. 
though it was the national boundaries that moved, not them. In different nation-state settings and into their eventual and continuing dispersal into a global diaspora of sorts, they have accumulated various and overlapping migrant statuses and existed in multiple and often contradictory states of exclusion and marginality, even as they increasingly comprise a large percentage of the global refugee population that has been formally resettled in third states, with the accompanying economic and social rights.

Although their collective experience of migration, refuge, and dispersal is both driven by and to be understood within its own historic context and the interplay of religious and ethnic dynamics in a country that has retained its independence in a region that continues to be defined primarily by colonization and its aftermath, the Lhotshampa can be taken as emblematic of larger inquiries into citizenship and belonging in contemporary South Asia (Caddell, 2005; Daiya 2008; Sadiq 2008), as well as of globalized and globalizing migrations. ${ }^{2}$ Efforts to locate their national identity and citizenship claims can be extrapolated not only toward the understanding of the experiences of other refugee populations in and into the region, like the Rohingya of Myanmar, but also of marginalized minority communities in countries dominated by nationalist politics, like Muslim citizens of India, whose citizenship claims can seem compromised and outright threatened amid mass emigration from Bangladesh in the region, in which purported economic migrants travel the same fraught pathways as refugees and settle in vulnerable urban Muslim communities. South Asia both today and in the twentieth century is and was a site not only of hypermobility, as has been argued elsewhere in this collection, but also of negotiated, disputed, and in some cases, imagined borders. ${ }^{3}$ Identity communities forged by migrations and resettlements, forced or otherwise, during the imperial and colonial occupations of this

2 Scholarship from the sociology of globalization, which I will cite in the next section, emphasizes that global migration must be seen as not just a consequence, but also an engine, of globalization. Here, I am simply distinguishing between migration that is globalized (networked and interconnected across the globe) and migration that is globalizing (which forges rather than follows pathways of communication and commerce).

3 Although I do not delve into border studies in this chapter, I should point out that the field has undergone some powerful transformations in the twenty-first century. As van Houtum, Kramsch, and Zierhofer wrote in 2005 , whereas in the past border studies was largely the study of boundaries or demarcations, 'border studies can now dominantly be characterized as the study of human practices that constitute and represent differences in space.' I also argue that borders often exist in the collective imagination of peoples who engage in different and differentiated human practices, who relate to and cross these borders in different ways, and that the imagined borders of different groups may differ. Further, it should be noted that South Asia is a site of a number of border disputes and conflicts. 
region must navigate questions of belonging in countries that have themselves continued to grapple with the concept of a national identity throughout the post-colonial era and well into the age of globalization. ${ }^{4}$

Our world today is being shaped by migration in more ways than we can possibly comprehend, and yet migration itself remains a great mystery. Migration scholarship generally suffers from poor data and is often unable to prompt meaningful policy solutions in nations that are driven by narrow or xenophobic approaches to migration management; yet, in the face of these structural challenges migration scholars strive to theorize today's global world. Migration scholarship seeks to offer insight amid unprecedented rates of irregular migration and undocumentedness, complicating the already complex picture of multivalent legal migration and rocket-fuelled urbanization. As the source of the world's largest diaspora ${ }^{5}$ and its fastest-growing pool of irregular economic and climate-change migrants; as the leading non-Western recipient of both labour and capital; as a site of endemic poverty and slavery, in which citizenship is no guarantee of rights; as a site of recurring refugee crises driven not just by war but by identity politics (for want of a better word); and as the leading non-Western locus of political Islamophobia, South Asia provides a powerful lens through which to understand the increasingly complex challenges surrounding citizenship and belonging today.

This chapter seeks to illuminate some of the complex realities surrounding citizenship and belonging in South Asia, and its regional hegemon India. Through an analysis of two refugee populations - the Lhotshampa of Bhutan and the Rohingya of Myanmar - I illustrate how migration in the region is characterized by a layering of statuses and migration experiences, which, against the backdrop of post-colonial and emerging identity politics, as well as the hypermobility described elsewhere in this volume, complicates not only our efforts to understand migration but also to document undocumented and stateless populations. In the case study of the Rohingya

4 I intentionally identify this group of people as Lhotshampa, the Bhutanese word for 'southerners', to emphasize that their group identity is not drawn from their language or ethnicity, but rather from the geographic region in which they have historically lived. That they can literally be considered natives to that region and at the same time excluded as outsiders, that their given name (a name they rarely use to describe themselves, by the way) refers not to their distinguishing characteristics but to a territory from which they have been expelled, illustrates the profound doublethink surrounding their rightful claim to citizenship.

5 The 2015 International Migration Report (http://www.un.org/en/development/desa/population/migration/publications/migrationreport/docs/MigrationReport2015.pdf), published by the UN's Population Division, states that India's diaspora has grown 60 per cent since 2005 to become the world's largest. This piece in Quartz India summarizes the report's data specific to India: https:/qz.com/594139/indias-diaspora-grows-6o-in-a-decade-to-become-the-worlds-largest/. 
from Myanmar, I examine complicating factors that are emerging in their accelerating migration into Bangladesh. Then I examine how the shifting political landscape in India further exacerbates the official paralysis toward developing an appropriate migration policy regime in the region. Finally, I conclude with a broader discussion of the causes and consequences of global, globalized, and globalizing undocumentedness, and what this multifaceted and poorly understood reality bodes for the future of a world on the move.

\section{Migration and Citizenship in a Global Age}

In the last decade, migration scholars have begun to grapple with a growing realization that many of the extant and widely accepted theories of migration are insufficient. Dana Diminescu writes, 'migration theories seem to be hobbled by a vision that continues to separate migrant mobilities from sedentary mobilities, migratory trajectories from urban itineraries, transnational circulations from proximity movements, and so forth' (2008: 566 ). Until recently, many theoretical models of migration continued to rest on Ernst Ravenstein's Laws of Migration (1885); even a century later, Dorigo and Tobler's mathematical model of migration tacitly accepted Ravenstein's premises as law even though the evidence in front of their very eyes should have undercut at least three of the said laws (Dorigo and Tobler 1983: 1). Certainly, many instances of these patterns of migration have existed for centuries and continue to exist today, but it is undeniable that the motivations, pathways, and patterns of migration are far more complex than we have traditionally held to be the case: migrants move not just from poverty toward wealth, from rural to urban environments, from one country to another, but also in patterns and pathways that are invisible, submerged, cyclical, networked, impelled by social or other factors, or which otherwise defy what might be thought of as the most obvious, most visible logic of risk versus reward or cost versus benefit.

Globalization scholarship, in particular the theories on globalization emerging from the field of sociology, has increasingly entered into this breach. Still, Saskia Sassen, the leading voice in the sociology of globalization, cautions against simply projecting notions of globalization onto migration (i.e., assuming that migration merely exists because of globalization) and exhorts migration scholars to understand whether and how migrations are or are not 'shaped by, grounded in or merely inflected by globalization' (2007: 129). According to Diminescu, globalization studies have accomplished this goal: 'Globalization, network theories and transnational processes have pointed up certain aspects that can be used to configure his future profile: 
multi-belonging (to territories and to networks), hypermobility, flexibility in the labour market, the capacity to turn a relational dexterity into a productive and economically effective skill are all features that we will certainly find in the make-up of our migrant' (2008: 569). Diminescu is just one of many scholars who point to hypermobility as a defining feature of contemporary migration, but it should also be briefly noted that a growing body of literature points to the ways migrants have also been immobilized during this era of presumed unfettered international movement. Craig Martin writes, ' $[t]$ he trajectories of those vulnerable peoples "locked-out" of global flows are replete with periods of extreme turbulence in the form of ceaseless movement that they have little control over, through to phases of stillness, "chronic waiting”, and uncertainty' (2011: 193). Or, as Ronen Shamir writes, 'while globalization is a lived reality of hypermobility for a small social stratum of "cosmocrats", mobility is still a scarce resource, and the overwhelming majority of the world's population is more or less permanently immobilized. Yet, regardless of the attention given to the widening mobility gap of the present era, globalization is predominantly theorized in terms of social openness and social fluidity' (2005: 197). Nonetheless, the promise, if not outright quality, of hypermobility certainly characterizes and compels migration in a globalized age. While others in this volume speak to hypermobility and labour market flexibility in South Asia, the feature I wish to extract from Diminescu's conceptualization of the contemporary migrant is what she calls 'multi-belonging'. Narrowly interpreted, this term refers to the fact that migrants define social and political belonging not just based on their physical location but also through their participation in certain identities, communities, social practice groupings, or networks. From this we can extrapolate the idea that understanding migrants' experiences and identities is central to theorizing migrant behaviours, including their movements.

Criticizing turn-of-the-millennium migration studies for its 'focus on single major factors and [... the] consequences of dominant structures rather than attend[ing] to obscure networks or subtle processes', Nikos Papastergiades has called for an approach in which 'the identity of migrants is not subordinate to external categories, but formed out of their own experience of movement and settlement' (2013:33-35). Central to the migrant's experience of movement and settlement is her access to documentation and, ultimately, to citizenship. In a 2015 article, I have maintained that amid the globalization of migration is also the globalization of undocumentedness, in which we see not only an increase in long-standing undocumented and unauthorized migrant populations, but also an increase in undocumentedness worldwide, along with the emergence of newer migrant destinations (Rajagopalan 2015). 
Urban planners and architects describe the beaten tracks that pedestrians and cyclists make through the grass between official sidewalks and roads as 'desire lines'. This term beautifully captures what happens in migration. As Sassen writes, 'in large-scale migrations the option to migrate is socially produced' (2007: 132). In other words, migrants travel pathways that have been revealed in communication with others who have gone before, but also with others who are fantasizing, dreaming. Jeffrey Cohen and Ibrahim Sirkeci assert that an understanding of contemporary migration patterns must derive from an analysis that accounts not just for economics but also culture, or 'the social practice, meaning and symbolic logic of mobility' (2011: ix). Overlay this web of desire lines and a culture of migration that is increasingly found in societies worldwide on a map of the proliferating 'migration fields' (or ethnic enclaves) generated by the confluence of exclusionary or restrictive migration regimes with the emergence of many more urban centres and migrant destinations, and the old model of 'chain migration' becomes what can be understood as chain-link migration. A widening web of networked, interconnected South Asian diasporas now exist: Pakistanis from England to New York, Bangladeshis from the Persian Gulf to Kuala Lumpur, Indians from Uganda to Canada.

And yet, the countries and regions that determine whether, why, and how it is permissible to migrate in the narrowness of these determinations interrupt and paralyse parts of these desire line pathways, rendering ever-greater numbers of migrants unauthorized, undocumented, unacknowledged, and unprotected. Migration and citizenship policies that do exist in the South Asian region are fraught with politicized considerations and intentional exclusions, rendering the region's rapidly proliferating cross-border migrants unauthorized or out-of status, often in possession of multiple, overlapping, or invalidated documentation. And yet, at the same time, migration is both prolific and accelerating, with border crossings negotiated through informal transactions or undertaken through the porous regions where national borders run through tribal or ethnic territories, separating brother from sister and kin from homeland.

\section{Multiple Belongings and Exclusions in South Asia}

While many regions and the migrant populations moving within, through, and from them must cope with similar challenges surrounding questions of citizenship and inclusion in a global, hypermobile age, South Asia functions as a particularly heightened site for such enquiry. The space where India, 
Nepal, Myanmar, Bangladesh, and Bhutan coexist (in some places meeting, in some places overlapping) is not only an ethnically diverse region that has been historically overrun with geopolitical intrigue and imperial play, but it has also experienced overlapping migrations unleashed, variously, by political repression, economics, and natural disasters. Some of the borders in this space remain porous and poorly controlled, while others have been extensively disputed, hotly contested, and heavily militarized. Yet the countries in this region continue to have incoherent, incomplete, and reactive migration policy regimes, as well as limited migration management capacity. These migration governance systems would falter in the face of much simpler migration patterns than the high-frequency, often traumatized, and sometimes cyclical cross-border migrations in this region of South Asia.

Bhutan is not the only country in South Asia grappling with how to limit its definition of rightful citizens on the basis of identity markers, which in turn mark others that are native to its territory or region as outsiders. A particularly stark example of a country paralyzed by its efforts to define the Venn diagram in which residence, ethnic identity, and paper trail come together to create a rightful citizen is Myanmar. The country's controversial 1982 citizenship law divides its population into four categories: citizens (those belonging to the 135 ethnicities the British say were there before they arrived in 1823); associate citizens (those who were there before the British left on 4 January 1948); naturalized citizens (those eligible for associate citizenship but who did not apply); and foreigners. Counted as foreigners are Eurasians, certain Chinese, Indians, Gurkha, Pakistanis, and, of course, the Rohingya (known inside Myanmar as 'Bengalis') - many of whom have lived in Burma for generations and have no other citizenship. While these so-called 'foreigners' were allowed to vote in the national referendum election in 2010, they were not permitted to vote in the country's first national parliamentary election in 2015 that brought the long-persecuted pro-democracy icon Aung San Suu Kyi to power. This issue came to a head when the government revoked the legal 'foreigner' status from 400,000 Rohingya and required them to apply for citizenship as illegal immigrants in squalid 'registration camps', triggering an internationally scrutinized humanitarian crisis as thousands of people took to the seas in flimsy boats in the summer of 2015. An analysis of the 1982 citizenship law reveals it to be an exceedingly tortured exercise in defining the psychic boundaries of a nation. And, as if the categories of belonging to the Burmese nation were not complicated enough in the letter of the law, they break down further in how the law is implemented. In Myanmar, it turns out that identity is 
haphazard, erratic, and defined largely by prejudice, as I learned in nearly every conversation and encounter I had with locals of many backgrounds and statuses during my field research into citizenship and migration in the region during the summer of 2015. For instance, I met a young Muslim man in Mandalay who was the child of an ethnic Shan woman and a man whose grandparents had migrated from a state in contemporary India. His identity card reads that he is Pakistani - but he was naturalized because his mother is a full citizen. Another man I met identified (and was officially identified) as Chin, but after a long chat admitted that he actually speaks a Chin dialect linguistically similar to an Indian language, which is not an officially recognized language of Myanmar. He believes that this would have designated him as an Indian, a foreigner, if he had mentioned it during his interview to receive his identity card. It should be noted that it is not just the small authoritarian states that struggle with this exercise: India also has a citizenship policy that has steadily narrowed its definition over time. I will return to this in the next section.

Although Myanmar has historically been considered a part of Southeast Asia and not South Asia, both the patterns of the country's struggles to define rightful claims to citizenship for its multi-ethnic population and the Rohingya crisis compel us to view Myanmar as a part of South Asia. Sassen writes, 'citizenship is an incompletely theorized contract between the state and its subjects. Further, it is meant to be incomplete [...] this incompleteness makes it possible for a highly formalized institution to accommodate change - more precisely, to accommodate the possibility of responding to change without sacrificing its formal status' (2007: 277). What characterizes the central crisis of citizenship and exclusion in South Asia, and what formally links Myanmar with the citizenship problematics of Bhutan, Nepal, and India, is that it seeks to create a citizenship that does not accommodate change - that speaks to an eternal and true and rightful nation. This is not to say that citizenship in Europe or elsewhere was premised on the flexibility of the nation, or intended to expand to accommodate growing and diversifying populations. Rather, as Bénéï writes, citizenship 'was from the outset an arena of contested meaning in two ways: contestation and competition from different groups within this arena, and the exclusion of others (women, subordinate nationalities, slaves, colonial subjects, the urban poor, the working class and the peasantry) altogether' (2005: 3). The Rohingya crisis further binds Myanmar to South Asia. Not only has Myanmar historically referred to the Rohingya as 'Bengali', but Bangladesh has also taken in over 6oo,ooo Rohingya refugees in the latest resurgence of the crisis in the fall of 2017. 
South Asia is also the origin point of the most long-standing, global, and evolving diasporic networks in the world. ${ }^{6}$ While India is the origin of the world's largest diaspora, emigration from Bangladesh is truly pushing the notions of belonging and citizenship both in the region and globally. For at least two decades, Bangladesh has been one of the world's leading exporters of people, sending an estimated 8.6 million migrants out into the world to date. Demographers now project that Bangladesh will send at least 15 million so-called climate refugees overseas by 2050. Even these numbers are mere guesses; there are no official data on irregular migration in the world today, and total climate refugee projections range from 50 to 200 million. Between 1990 and 1995, Bangladesh sent 1.2 million migrants into the world, and these numbers more than doubled to some 3 million between 2005 and 2010 - outstripping both China and Mexico by more than one million people during this same time period. Approximately half of these migrants made their way to the Persian Gulf, primarily to the UAE and Saudi Arabia, and more than 600,000 crossed over into neighbouring India. But during this same time, more than 280,00o Bangladeshis migrated to Southeast Asia, primarily to Malaysia, and nearly 230,00o landed in Europe - more than 60,000 of whom settled in Italy.

Bangladeshi migrants have mostly been called, and treated as, economic migrants. But the lines between economic migrant and refugee are blurring: as many as half of the people fleeing the 2011 war in Libya who landed in a temporary refugee camp just inside the Tunisian border were Bangladeshi migrant workers. Their stories revealed the layered complexity of today's migrants: many had signed with 'brokers' who promised contracts for oil field jobs in a liberalizing post-2007 Libya, only to find that the country had no legal infrastructure for guest workers, and that they had in fact become undocumented workers, were trafficked persons, and were now becoming refugees. Today, migrants from Bangladesh are largely unaccounted for, travelling increasingly dangerous and hidden pathways, often trafficked alongside refugees, and are facing greater violence and discrimination where they land, often as undocumented workers, in societies with spiking Islamophobia. Climate change will exacerbate these already desperate crossings; some 634 million people around the world are today at risk of

6 Minal Hajratwala compiled these statistics about the Indian diaspora historically and today: http://minalhajratwala.com/writer/leaving-india/stats/. Gaiutra Bahadur's Coolie Woman: The Odyssey of Indenture (2013) narrates a history of indentured servitude from India in what eventually became a diasporic community, a history whose roots and later diasporic branches have been powerfully animated in literature, most notably in Amitav Ghosh's Sea of Poppies (2008). 
rising sea levels (Greenfieldboyce 2007). And as more and more countries seek to combat terrorism through immigration policy and closed borders, more migrants will only face greater challenges to finding safe havens outside of their homelands. Although many countries will be affected by climate change, it is the resilience and reach of diasporic networks originating in the northeastern corner of South Asia that will push its populations across borders - and further out across the globe. That a significant percentage of this migrant population will comprise Muslim Bangladeshis in a world that is increasingly hostile to migrants - and doubly hostile to Muslim migrants promises to pose ongoing challenges to the social and physical well-being of these migrants, as well as to the long-term development and stability of both the sending and receiving communities (Etzold and Mallick 2015; Kibria 2011).

The first stop in Bangladesh's diasporic network is India. Labour and climate migrants from Bangladesh comprise just a part of the pool of people seeking to immigrate to India, both from its immediate neighbouring countries and from elsewhere in the world, and yet India continues to have no comprehensive or systematic way for people to immigrate legally. ${ }^{7}$ At the same time, Hindu nationalist leaders regularly make inflammatory public declarations that the country has been overrun by upwards of 20 million 'illegal infiltrators' from Bangladesh (The Hindu 2014). This claim is nearly impossible to verify, but of far greater concern is its potential for inciting ill will and even outright violence against Indian-born citizens who are Bengali, Muslim, or from marginalized tribal communities. Further, as workers in India continues to experience widespread slavery and labour exploitation; as certain caste-based and tribal communities continue to experience systemic marginalization; and as high rates of rural-urban and internal migration upend existing social structures and diversify once homogenous local communities, questions of inclusion and belonging will intensify (Singapur and Sreenivasa 2014). ${ }^{8}$ Such trends suggest not only that India will continue to grapple with ongoing questions about citizenship and belonging, but also,

7 A 2014 report by the Migration Policy Institute offered several statistics on immigration into India from neighbouring countries through refuge, asylum, and labour migration, observing that India had no specific law to address refugees and asylum seekers arriving without documentation (who are many), and asserting that 'India arguably has long served as a destination for economic migrants and refugees from neighbouring countries. Yet policymakers and Indian society have yet to address head-on challenges related to illegal immigration from Bangladesh.' (Abbas and Varma 2014).

8 According to Walk Free's Global Slavery Index, India is home to the majority of the world's enslaved people, many of them native-born and legal citizens of India. Some eighteen million people live in conditions of modern slavery in India, according to the foundation's 2016 index, which considers bonded labour, various forms of unregulated domestic work and child labour, 
given India's place as a global power, that India could function as a global influencer and amplifier of the more destabilizing aspects of twenty-first century migration: the justification of restrictive immigration policies with Islamophobia, failure to respond to evolving migration realities, and exacerbation of the globalization of undocumentedness.

\section{A Story of and from the Borderlands: Shyam Rai}

Lauded the world over as the happiest place on earth, a benevolent Buddhist kingdom above the clouds in the lush green mountains of the eastern Himalayas, Bhutan at the end of the twentieth century undertook a massive, three-decades-long ethnic cleansing effort to rid itself of the people they called Lhotshampa ('southerners'), who at one time constituted one-sixth of the national population. Lhotshampa have existed in the land that lies in present-day Bhutan for generations, but they speak Nepali instead of Bhutanese and practice Hinduism, or in some cases Christianity, rather than Buddhism. They number among the peoples of South Asia who represent the liminal nature of identity and belonging in a region traversed by porous, shifting borders; governed by incomplete and incoherent citizenship laws; struggling to align national territories with complex linguistic, ethnic, and religious groupings; and grappling with both tremendous geopolitical pressure from outside the region and epochal hypermobility within the region. Their stories are among many that can begin to shed light on the complex realities surrounding citizenship and inclusion in this part of the world.

Homeless and stateless, the Lhotshampa were not taken in by the nation they saw as their own. Nepal was already hosting a large Tibetan refugee population and struggling to put down the Maoist rebellion that eventually toppled its monarchy, so it declined to integrate the new arrivals and declared the Lhotshampa citizens of Bhutan. Instead of granting work permits or other avenues for making a new life, Nepal called in the United Nations High Commissioner for Refugees (UNHCR), who placed them in seven refugee camps - and then began a decades-long and repeatedly unsuccessful effort to negotiate their return to Bhutan. Nepal's unwillingness to expend resources to deal with this population offered one silver lining: no Nepalese military or law enforcement were installed to guard the camps, so the Lhotshampa were free to come and go. 
When he was a teenager, Shyam Rai, whose story opened this chapter, began joining his fellow Lhotshampa in crossing over into India in search of work. Bhutan, Nepal, Bangladesh, and India are separated by a protuberance of mountainous, landlocked, multi-ethnic, and relatively impoverished Indian states like Sikkim and Assam, and although the border between Bhutan and India is strictly controlled (there is only one official overland opening into Bhutan in its 434-mile-long border with India), India and Nepal have had an open border treaty since $195^{\circ}$. In the years since this treaty, this part of Nepal has received Tibetan refugees following China's annexation of Tibet in 1959, Nepalese returnees from Burma following the enactment of Burma's restrictive 1964 Citizenship Act, ethnic Nepalese fleeing antiforeigner violence in India, migrant labourers from the Nepali hills and from India seeking opportunities created by Nepal's 1964 Land Reform Act, the Lhotshampa throughout the 1990s, and a steady stream of refugees fleeing natural disaster from all sides. Although the open border treaties laid out trade specifications, none of them provided border management stipulations, according to geographer and scholar Vidya Bir Singh Kansakar (2001). She identified 22 official transit and customs points between the two countries, as well as several more sub-customs posts through which the so-called illegal (a more accurate word might be ungoverned or perhaps informal) movement of goods and people can happen with no more than an informal agreement between those who wish to cross and the transit post's personnel.

Asked how they managed to navigate the border, Rai says that the soldiers at the Indian border checkpoints asked questions designed to intimidate or impel tribute much more than to verify one's nationality or enforce a law. 'If you answered right, they just waved you through', he says, and the right answer had more to do with posture and temperament, with diplomacy and finesse, than with facts. 'They would sometimes ask for [an] ID but we had none. I used to say I'm from Sikkim, my house is just over there.' Then he would enter India, into a state that had remained an independent Buddhist monarchy until 1975, where Nepali was still the lingua franca, and where the locals looked and spoke and in many cases prayed like him. Other Lhotshampa would work in the terraced rice or cardamom estates, or as street vendors hawking snacks and crafts to the tourists, but Rai often worked on construction sites, sleeping in a tent in the corner of a muddy lot. 'Sometimes when it came time to pay, they'd run off, and where were we to look, who were we to tell?'

A stateless person, a refugee, a migrant worker, and an unauthorized migrant, Rai accrued a stack of outsider statuses over the course of his 22 years in Nepal. He and his by now more than 100,000 compatriots spent those years hanging 
in extended limbo, the peculiar state of forced suspended animation in which protracted displaced populations must abide, denied statehood, livelihood, and, in many ways, full personhood (Bird 2012). And yet, despite the years of exclusion, the lack of opportunity, and the outright rejection he faced in Nepal, he thinks of himself not as Lhotshampa, not as Bhutanese, but as Nepali.

He and several of his relatives were resettled in 2013 to the US, to Utica, a frostbitten post-industrial town in the northern reaches of New York State. For the first time in his adult life, he was a legal migrant with rights, included in the social and economic fabric around him. As soon as his visa was finalized and he could travel internationally, he returned to Nepal and married a Nepali citizen. Chatting happily about his new bride and his plans to bring her to the US as soon as he was naturalized as a citizen (a process that could take an additional five years), he said that she was waiting back 'home' in Kathmandu, 'in my country'. Rai has in essence constructed an identity narrative in the spaces between nations, in which borders are irrelevant, citizenship is flimsy, and belonging occurs independent of political participation and policy-based infrastructures of incorporation and integration. While we may gain some insight into his identity from Benedict Anderson's famous conception of the 'imagined community', Rai's faith in his collective identity and his belonging to a mythic nation that exists as much in his imagination as in reality, what he really represents is identity formation as a coping mechanism and survival strategy. Certainly, his self-identification as Nepali can be understood as a 'cultural artefact' that is "modular", capable of being transplanted, with varying degrees of self-consciousness, to a great variety of social terrains' (Anderson 1991:4), but it also reflects an act of will in the face of outright rejection and structural exclusion, both by his state of residence and the nation he claimed. His chosen nationality is unidirectional and unreciprocated. What profound impacts must such a protracted and extensive experience of exclusion have on him and, therefore, on all the communities in which he participates?

These are important and perhaps necessary explorations for this new century, but the objective of this story, and of this chapter, is not to discuss the intricacies of identity formation or the nature of nationalism today. Rather, it seeks to illuminate the many more complicated features of identity and belonging in an age of both hypermobility and globalized migration than had previously been conceptualized or currently accounted for. When nationality becomes untethered from place through migration (including displacement and refuge); when it is carried across multiple cultural and national borders; and when it is embedded in and compounded through global diasporic networks, then the structures surrounding migration, 
incorporation, and citizenship take on far greater significance. If these structures are incoherent, incomplete, or limited, then the migrant excluded from them suffers. If they are further eroded by xenophobia and nationalist political rhetoric, then entire communities become out-groups and experience not only incoherent or contradictory statuses, but are viewed as illegal and illegitimate, even when there is no real pathway or structure for them to pursue legal immigration. And in this era of mass, global migration, this experience becomes multiplied, compounded, and globalized.

Today, as the anthropologist and Utica-based refugee rights advocate Kathryn Stam describes in a 2017 paper with human rights scholar Lindsey Kingston, Rai is an example of someone 'recovering from statelessness'; he and his fellow resettled refugees who are attempting to make a life in an economically depressed town, must overcome the systemic, lifelong marginalization and coerced dependence they have experienced in order to independently and agentically navigate schools and workplaces, manage their homes and family needs, and participate in the communities surrounding them. As the resettled Bhutanese Nepali populations interact with the growing, often undocumented, labour migrant populations from Nepal, their differential experiences of inclusion and exclusion, of citizenship and statelessness, of emigration and displacement, of immigration and resettlement, of forced passivity and necessitated agency come into play, extending and manifesting the complex dynamics of identity narratives from the borderlands of South Asia in a wholly new terrain. In this story, we can observe the liminal identity in motion, nurtured in the face of trauma, rigid national boundaries, limited citizenship laws, multiple layers of migrant status, and global migration pathways. Rai's story - and the broader Lhotshampa story - is emblematic of the complications surrounding citizenship and belonging in South Asia, where borders cross through landscapes in which physical borders simultaneously have little practical and heightened symbolic meaning.

\section{Hypermobility and Hegemony: Nationalist Rhetoric and Migration Realities in Contemporary India}

Migration is complicating the already complex picture of belonging and identity in India. In addition to rapid urbanization and the rural-urban migrant flows it presupposes, migrant workers are crossing intra-state borders as construction or cyclical workers in regions that are linguistically and socially different from their own. At the same time, India continues to struggle with deep fissures between social groups of native-born citizens - from systemic 
and recurring communal and caste violence to ongoing and widespread labour exploitation, trafficking, and slavery. Against this backdrop, new forms of international migration are complicating the already complex picture of mobility and social change. Not only have India's eastern borders long been characterized by porousness and fluidity - refugees and stateless persons from Nepal and Bhutan regularly join tribal cyclical migrants and economic migrants from Bangladesh and Myanmar in moving relatively freely through the unmanned swathes of the region's border -, but India does not appear to have a comprehensive policy to allow low- and middle-income people from the region to legally immigrate and access citizenship.

Indian political rhetoric has, as in many countries worldwide, tacked toward the nationalistic and xenophobic in recent years. Indian Prime Minister Narendra Modi rose to national power on a campaign that, like the successful right-wing campaigns sweeping Europe and the US, spoke to economic anxieties plaguing the country's middle class in an era of widening inequality and increased costs of living, inflected with heavy notes of religious and ethnic nationalism - saffron-washing the complex Indian social landscape. Modi has a long and intimate association with Hindu nationalists and ultranationalist militants, and although he was officially cleared of any role in inciting riots and violence against Muslims in the city of Ahmedabad during his term as the state of Gujarat's chief minister in 2002, a genocide and subsequent pogrom did take place on his watch. He has never issued a public apology or publicly expressed any regret or remorse over these events. In fact, his campaign continued to appeal to anti-Muslim sentiments, taking security and xenophobia from the universal nationalism playbook, and many of the local and state-level affiliates of his parties have openly made anti-Muslim declarations.

Kamal Sadiq writes that 'Indian citizenship began on a civic note, as a regime of jus soli, but has evolved into a more exclusionary citizenship regime' (2008: 9), detailing measures taken to restrict citizenship in response to circumstances such as the refugee crises unleashed during the war for Bangladeshi independence and the Sri Lankan civil war, or the growing and increasingly influential Indian diaspora. Observing that Indian citizenship has increasingly come to be viewed as 'precious', or as in some way under attack, he writes,

The curtailment of Indian citizenship by imposing restrictive residential requirement, narrowly defining 'persons of Indian origin' to ensure their 'Indian' nationality, security the political rights of Indian citizenship from the claims of the diaspora - all reflect a growing anxiety on the part of the 
Indian state toward new and old outsiders. It seems that the nation has to be protected from an ever-ready stream of illegal immigrants waiting to contaminate the fabric of Indian citizenship. Central to these concerns have been the elimination of claims to Indian citizenship by Bangladeshi and Pakistani nationals (or their descendants). (Sadiq 2008: 11)

He then goes on to demonstrate how, despite prohibitive financial and structural barriers to legal immigration and naturalization, and despite the fact that the very concept of citizenship arises from a determination to prevent cross-border migrants from neighbouring countries from accessing that citizenship, millions of what he calls 'document-bearing' migrants regularly access the privileges of citizenship in India by obtaining local or municipal documentation, such as a ration card (Sadiq 2008).

Andrea Cornwall and Vera Schattan Coelho begin with the premise that the central challenge of democratic societies is 'building democratic polities where all can realize their rights and claim their citizenship' (2007: 1, 272). What they are describing underlies what human rights scholars describe as the rights-based approach to development. India, a post-revolutionary state, guarantees its citizens many and elaborate rights, which many are prevented from accessing due to poverty, custom, ill health, lack of education, and the lack of local capacities to govern, implement, and enforce those rights. Much has been written on efforts to connect farmers, women, and children to property rights, reproductive justice, and schooling, respectively - to name just a few. But many of traditional rights are tied to a specific place, and in an age of tremendous mobility these rights become even more elusive.

According to the 2007-2008 national household survey, more than one third of all Indians were internal migrants (Ministry of Health and Family Welfare 2010). Despite their status as Indian citizens, internal migrants live, work, and move as undocumented and unauthorized migrants. A June 2013 UNESCO report documents that many internal migrants do not have proof of identity, residency rights, political representation, or home ownership where they live and work. While some internal migrants are professionals, the overwhelming majority are poor and low-income workers in insecure or informal work, living in slums or informal settlements, vulnerable to trafficking, and excluded from accessing social services provided by the state government, such as public health and education services. Many face discrimination on the basis of race, language, ethnicity, or caste (Faetanini and Tankha 2013). While the Indian government's national household survey identifies some 80 per cent of the country's internal migrants as women, Abbas and Varma write that labour-driven internal migration is primarily 
undertaken by men; internal migration as a result of marriage or contracted employment is dominated by women. They identify the rural-urban divide and quest for livelihood as the primary engine of internal migration, and yet they report that about 19 per cent of the Indian population (some 191 million people) reported migrating long distances to other districts or other Indian states, according to the 2001 census data (Abbas and Verma 2014). Given that India functions as a confederacy, in which each state has its own official language, political parties, social service infrastructure, identification regime, and governance structure, internal migrants across state lines face many of the same challenges experienced by international migrants moving across national borders - at least those moving across the porous, less militarized international borders in the region. Further, according to Australia-based human rights organization Walk Free, India has the highest number of enslaved people in the world, at eighteen million (Global Slavery Index 2016).

Thus we see that local structures in many ways supplant or bypass national structures of citizenship, and in doing so, puncture the national idea of citizenship. If citizenship has less to do with status and more to do with the accessibility of rights, then entangling complexities of legality and illegality, formality and informality, participation and belonging both unravel and bind the processes of incorporation and inclusion in day-to-day life.

\section{Conclusion}

Nearly every country on earth has 'unauthorized' immigrants. Certainly, countries with rapidly expanding economies and increasing rates of immigration must grapple with how to develop and implement a migration policy regime. But unauthorized, unaccounted-for migration touches on deeper questions that lie beneath the administrative talk of visas and customs in a globalizing world. Many of the so-called middle-income countries - the powerhouse economies in Asia, Africa, and Latin America that are becoming immigration hubs - are surrounded by countries embroiled in conflict or economic collapse, struggling with poverty, staggering inequality, endemic violence, and massive internal migration. Many of these countries have high rates of slavery or trafficking, and some have recently experienced civil war or genocide. If even citizens by birth or naturalization can be considered outsiders, found fundamentally undeserving by some kind of unspoken consensus, what does it mean to have a right to be somewhere, to deserve to work somewhere, or to belong somewhere? 
Questions of citizenship, identity, and belonging affect immigrants and native-born populations alike in most countries. These questions are all the more heightened in countries facing growing inequality and massive internal migration prompted by endemic poverty, recurring violence, and ultra-rapid urbanization. While many scholars have argued that the US and Europe should take a different, less costly approach to migration - one that starts with the realities and challenges of the local community -, it is all the more imperative that countries with vastly different political, social, economic, and military concerns should do so. Such an approach might not necessarily lead to perfect solutions and whole, healthy, and well-integrated communities, but it would not criminalize migrants or make them vulnerable to discrimination, exploitation, trafficking, or enslavement. In fact, a growing body of evidence, most starkly laid out by Tara Brian and Frank Laczko, suggests that the over-securitization of migration - a disproportionate investment in border security over efforts to incorporate immigrants, policies that treat migration status violators as criminals, systems focused more on detaining and deporting these violators than on adjusting or reforming immigration policy, policies that punish undocumented migrants far more harshly than the people who traffic or exploit them - has not only contributed to a proliferation of global trafficking networks, but has also directly correlated with a spike in migrant deaths in transit worldwide (Brian and Laczko 2014). Indeed, the US and EU have actively pursued a strategy of death-as-a-deterrent to unwanted migration, a perspective that if adopted globally would undoubtedly have grave humanitarian consequences.

India is not only on course to become the most populous country in the world; it is also on its way to becoming home to the world's largest Muslim population. It is home to one of the world's largest persistent and growing diasporas and is a democracy and the hegemon in a region struggling with ongoing political conflict, religious nationalism, poverty, and the effects of climate change. India is in every way global, globalized, and globalizing. How India responds to migration realities could not only have a lasting impact on its own social stability and economic potential, but its actions could also echo globally to stabilize or destabilize social interactions, and could influence policymaking on a grander scale. Perhaps now is not the moment for India to reproduce the paralysis, stagnation, and myopia that have characterized US and EU migration policymaking to date, but instead to lead and create a paradigm for citizenship in a complex, interconnected region in a global age. 


\section{References}

Abbas, R. and Varma, D. (2014). Internal Labor Migration in India Raises Integration Challenges for Migrants. Washington, DC: Migration Policy Institute.

Anderson, B. (1991). Imagined Communities. London: Verso.

Bahadur, G. (2013). Coolie Woman: The Odyssey of Indenture. London: C. Hurst \& co.

Bénéï, V., ed. (2005). Manufacturing Citizenship: Education and Nationalism in Europe, South Asia and China. Abingdon: Routledge.

Bird, K. (2012). The enigma of Bhutan. The Nation. 7 March. https://www.thenation. com/article/enigma-bhutan/

Brian, T. and Laczko, F. (2014). Fatal Journeys: Tracking Lives Lost During Migration. Geneva: International Organization of Migration.

Caddell, M. (2005). 'Discipline makes the nation great': visioning development and the Nepali nation-state through schools. In V. Benei, ed. Manufacturing Citizenship: Education and Nationalism in Europe, South Asia and China. Abingdon: Routledge.

Cohen, J. and Sirkeci, I. (2011). Cultures of Migration: The Global Nature of Contemporary Mobility. Austin: University of Texas Press.

Cornwall, A. and Coelho, V. (2007). Spaces for Change? The Politics of Citizen Participation in New Democratic Arenas. London: Zed Books.

Daiya, K. (2011) Violent Belongings: Partition, Gender, and National Culture in Postcolonial India. Philadelphia: Temple University Press.

Diminescu, D. (2008). The connected migrant: an epistemological manifesto. Social Science Information, 47(4), pp. 565-579.

Dorigo, G. and Tobler, W. (1983). Push-pull migration laws. Annals of the Association of American Geographers, 73(1), pp. 1-17.

Etzold, B. and Mallick, B. (2015). International migration from Bangladesh. Country Profile. Bundeszentrale für Polistische Bildung. http://www.bpb.de/gesellschaft/ migration/laenderprofile/216104/international-migration-from-bangladesh

Faetanini, M. and Tankha, R. (2013). Social Inclusion of Internal Migrants in India. New York: UNESCO.

Ghosh, A. (2008). Sea of Poppies. London: John Murray.

Global Slavery Index (2016) https://www.globalslaveryindex.org/country/india/

Greenfieldboyce, N. (2007). Study: 634 million people at risk from rising seas. National Public Radio. 28 March.

Kansakar, V.B.S. (2001). Nepal-India open border: prospects, problem and challenges. http://www.fesnepal.org/reports/2001/seminar_reports/Nepal\%2oIndia\%2o Open\%2oBorder.pdf

Kibria, N. (2011). Working hard for the money: Bangladesh faces challenges of large-scale labor migration. Migration Policy Institute. og August. https://www. 
migrationpolicy.org/article/working-hard-money-bangladesh-faces-challengeslarge-scale-labor-migration

Kingston, L.N., and Stam, K.R. (2017). Recovering from Statelessness: Resettled Bhutanese-Nepali and Karen Refugees Reflect on the Lack of Legal Nationality. Journal of Human Rights, 16(4), pp. 389-406.

Martin, C. (2011). Turbulent stillness: The politics of uncertainty and the undocumented migrant. In: D. Bissell and G. Fuller, eds., Stillness in a Mobile World. London: Routledge.

Ministry of Health and Family Welfare (2010). District level household and facility survey 2007-08. Government of India. http://rchiips.org/pdf/INDIA_REPORT_DLHS-3.pdf

Papastergiadis, N. (2013). The Turbulence of Migration: Globalization, Deterritorialization and Hybridity. New York: John Wiley \& Sons.

Rajagopalan, K. (2015). Global 'undocumentedness'. Journal of International Affairs, 68(2), pp. 225-243.

Ravenstein, E. (1885). The laws of migration. Journal of the Statistical Society of London, 48(2), pp. 167-235.

Sadiq, K. (2008). Paper Citizens: How Illegal Immigrants Acquire Citizenship in Developing Countries. New York: Oxford University Press.

Sassen, S. (2007). A Sociology of Globalization. New York: W.W. Norton.

Shamir, R. (2005). Without borders? Notes on globalization as a mobility regime. Sociological theory, 23(2), pp. 197-217.

Singapur, D. and Sreenivasa, K. (2014). The social impacts of migration in India. International Journal of Humanities and Social Science Invention, 3(5), pp. 19-24. The Hindu (2014). Bangladeshi 'infiltrators' would have to go back: Modi. 7 May. van Houtum, H., Kramsch, O., and Zierhofer, W. (2005). B/ordering space. Aldershot, Hants, England: Ashgate.

\section{About the Author}

Kavitha Rajagopalan is a Senior Fellow at the World Policy Institute and a non-resident senior fellow at the Carnegie Council for Ethics in International Affairs, specializing in global migration. She is the author of Muslims of Metropolis: The Stories of Three Immigrant Families in the West (Rutgers University Press 2008), which was a finalist for the Asian American Literary Award in Nonfiction, and is currently working on a book about the future of citizenship in a global age. Her work has been featured in The Atlantic, New York Observer, Newsday, Next City, The Feminist Review, and various policy journals, and she has frequently appeared as an expert commentator on MSNBC. 



\title{
$5 \quad$ Renegotiating Boundaries
}

\author{
Exploring the Lives of Undocumented Bangladeshi Women \\ Workers in India
}

Ananya Chakraborty

Jones, Reece and Ferdoush, Md. Azmeary (eds), Borders and Mobility in South Asia and Beyond. Amsterdam: Amsterdam University Press, 2018 DOI: $10.5117 / 9789462984547 / \mathrm{CHO} 5$

\begin{abstract}
This chapter draws from case studies of undocumented Bangladeshi women who are engaged in various informal-sector occupations in Maharashtra to highlight the multiple vulnerabilities and threats that they face due to both their status as undocumented migrants and their gender positioning in the informal labour market. Women in Bangladesh have long dealt with patriarchal institutions in all spheres of their lives. This, coupled with stubborn levels of poverty, the lack of adequate employment opportunities, and regressive migration policies for women, has led to the proliferation of hidden and parallel pathways for migration. While Bangladeshi men mostly migrate to countries in the Middle East and Southeast Asia, India remains one of the dominant destinations for undocumented Bangladeshi women. Using a mixed-methods approach, the chapter highlights the vulnerabilities and agency of Bangladeshi women in the face of extortive labour relations, weak gender positions, and socio-political vulnerabilities.
\end{abstract}

Keywords: undocumented migration, Maharashtra, informal sector, gender, labour

\section{Introduction}

Taslima, an 18-year-old widow from Satkhira, is one of the many Bangladeshi women struggling to eke out a living in India. ${ }^{1}$ After her husband died of stomach cancer merely two years into their marriage, she and 
her one-year-old son were shunned by her in-laws. One of her relatives introduced her to a dalal ('broker'), who promised her employment in Mumbai for a fee of about US $\$ 65$. She now works as a labourer at a construction site some 300 kilometres away from Mumbai making a little over US $\$ 70$ per month. Although the work is strenuous, she says that she prefers it to scrubbing pots and pans in exchange for meals at a relative's house in Bangladesh. Women like Taslima display agency in deciding to migrate for employment, given that their choices are limited by their geographical, social, and economic positioning. However, since their migration experiences do not fit into the statist conceptualizations of trafficked, coerced, or at-risk women, their vulnerabilities remain largely unaddressed within the migration paradigm.

Migration in South Asia follows gendered binaries: while most males are considered economic migrants, women are often seen as dependent migrants accompanying males - especially because of the prevalence of systems like virilocal marriage. The stereotypes of 'exotic mail-order brides, docile domestic workers, and/or distressed refugees and sex workers' typify the image of women migrants within this region (Joseph \& Narendran 2013: 12). Although fallacious, these views are often reflected in the domestic and global policy spheres, making women prone to multiple vulnerabilities by pushing their experiences of mobility into liminal spaces. Countries in South Asia routinely exert control over women's mobility through gendered access to migration channels, as Andrea Wright explains in the next chapter of this volume. This control particularly manifests in the case of poorer, illiterate, and younger women who are denied legal opportunities for employment through age, skill, and guardianship-related requirements for migration.

This chapter engages with the interaction between agency and vulnerabilities among undocumented migrant women who move from Bangladesh to India. Through an exploration of the multiple ways women renegotiate their positions within migration networks, labour markets, societal structures, and cultural formations in the course of their engagement with informal sector employment in India, I examine how constrained choices result in multiple forms of vulnerabilities among undocumented women migrant workers. These multi-layered vulnerabilities manifest in both overt and covert forms that limit further agency formation among women migrants. Thus, an empirical verification of agency and vulnerability among women migrants can provide valuable insights for rerouting the gender and migration debate from its narrow consideration of economic progress and situating it within the larger human development narrative. 


\section{Eroding Agency}

The question of agency is essential to understand how women negotiate their role in relation to larger structures that constrain them within patriarchal societies (Gammage et al, 2016). The scope of women's agency is determined by the collective structures of the society like societal norms, patterns of rules, property rights, and their positioning within the broader framework of the society. Agency is understood by Amartya Sen as the ability to set and pursue one's goals and interests. This is not limited to only improving one's own well-being, but also includes the furthering of the well-being of others, respecting social and moral norms, acting upon personal commitments, and pursuing of a variety of values (Sen 1977). When women are reduced to mere 'recipients' of the migration process, it obscures the very action of women undertaking arduous journeys to unfamiliar destinations in search of work (Sen 1985). Thus, understanding women's agency within the migration process requires a closer look at the specific motivations and constraints under which they act (Peter 2005).

For decades, women from the southwestern parts of Bangladesh, particularly Satkhira and Jessore Districts, have been known to migrate to India for employment (Blanchet 2010: 345-353). Such movements, where passports and visas are not important, has established a flourishing network of migrants, employers, and dalals who recruit and employ Bangladeshis in various informal sector occupations (Hujo \& Piper 2010). Despite its proactive migration policy, the Bangladeshi government does not acknowledge the movement of women across the porous border between India and Bangladesh. Moreover, the Indian government terms such movement as 'infiltration' and portrays such migrants as 'terrorists' in populist discourse (Ramachandran 2002).

The meta-narrative on South Asian migration does not capture such flows and counter-flows of people across borders. For instance, the Bureau of Manpower, Employment and Training (BMET), the Bangladeshi government agency in charge of registering and clearing labour migrants for overseas employment, estimates that between 1976 and 2016 a total of 10.2 million economic migrants have gone abroad to work, bringing back almost US\$162 billion in remittances (Bureau of Manpower, Employment and Training 2016a). However, women have always constituted a marginal proportion of the total migrants. Until 2003, they comprised merely 0.3 per cent of the total migrant population. Despite the successive introduction of affirmative policies aiming to promote women's migration, this proportion remained merely 4.7 per cent in 2015 (Bureau of Manpower, Employment and Training 2016b). 
The dismal number of Bangladeshi women in the offıcial workforce is a reflection of the policies that do not allow women under a certain threshold age to migrate, restrict them to certain sectors of employment, or require them to depend on male guardians. This restriction on women's choice and mobility forces them to take risks to circumnavigate these restrictions - which in turn renders them invisible within the migration process. The thin line between agency and vulnerability is evident in the case of Bangladeshi migrant women in India.

The exclusion of women from democratic decision-making processes presents a curious paradox where the state contributes to furthering the vulnerabilities of the very 'subjects' that it seeks to protect (Peter 2005: 29). Instead of making migration a secure and dignified experience, such policies increase the vulnerabilities associated with the migration of women, as they are forced to use hazardous and undocumented channels to access employment opportunities abroad.

\section{Invisibility and Vulnerability}

It is rather difficult to distinctly identify an individual as a Bangladeshi migrant in India. This study was conducted among 46 Bangladeshis employed in various informal sector activities - like construction work, fish- and meatpacking, and domestic work - in two urban and peri-urban regions of the western Indian state of Maharashtra. Since Bangladeshis are linguistically and ethnically similar to migrants from the eastern Indian state of West Bengal, it is often difficult to distinguish between them. For this reason, it is relatively easier for Bangladeshi migrants to assimilate and hide their identities in India. They remain concealed even in plain sight, unlike the organized Bangladeshi protestors of Antwerp described in the chapter by Malini Sur and Masja van Meeteren in this volume. Women from Bangladesh often adopt simple but effective measures to do this, such as taking up Hindu-sounding names or applying sindoor ('the vermilion mark worn by married Hindu women') in the parting of their hair. Even when they choose to retain their religious identities, they can easily pass for migrants from West Bengal, which has an almost 27 per cent Muslim population (Registrar General of India 2011).

These barriers to the identification of Bangladeshis among similar ethnic and linguistic populations necessitated the use of innovative methodologies. I contacted labour suppliers at both sites in Maharashtra, who then identified two individuals who were also dalals. It was primarily 
the dalals who introduced me to the Bangladeshi migrants. After this initial contact, further interviews were conducted during the course of repeated interactions over a period of three months from June to October of 2014. All these interviews were conducted in absence of the dalals. These meetings often began in the evening after the migrants returned from work and continued late in the night. Although there were several hitches in the initial days with exaggerated rumours by the contractor about dangers of talking to me, the participants placed their trust in me little by little over conversations about their village and life at the destination. My position as a Bengali speaking woman whose grandparents had ties to Dhaka before the partition of India in 1947 also allowed some leeway. This enabled the participants to engage with me in-depth and allowed them to place their trust in the research. Although this study initially attempted to concentrate only on women migrants, it was difficult to single them out since women are generally located in occupations like domestic work and the care industry that limit their visibility in the social sphere. Ignorance of local customs and languages at the destination also impedes women's visibility, forcing many women to limit their interactions outside their spaces of work. Thus, out of the total 46 workers, only 20 ( 43 per cent) were women. Although men also face similar linguistic and cultural barriers, it is easier for them to become a part of their destination societies, as they are located in sectors that often demand greater social contact. Thus, although their mobility is also monitored, men are easier to locate than women at the migration destinations.

A majority (96 per cent) of the migrants from Bangladesh practiced Islam. Nine of the migrant women (almost 45 per cent) were less than 25 years of age, and nearly thirteen (approximately 66 per cent) of them had not completed primary education. Fifteen (nearly 74 per cent) of the migrant women were married. Although national-level statistics reveals that almost 12.5 per cent of the households in Bangladesh are headed by a female, the proportion of such women in the present sample was around 9 per cent (World Bank, 2016). Female heads of households are particularly vulnerable; many of them are divorced, separated, or deserted by their partners and therefore dependent on male relatives or outsiders to assist them with the migration processes. Since Bangladesh mandates that a male guardian should accompany female migrants, this increases their vulnerability both during and after migration; in the absence of spouses or other males from their families, women can be victimized or duped into fake marriages by dalals or trafficked into bonded labour and/or prostitution. 


\section{Women, Work, and State Policies}

International migration from Bangladesh for work is a colonial phenomenon that continued even after the creation of East Pakistan. However, in the early years after Partition most of these migration routes were male-dominated and directed towards industrialized countries in the West. This phase was largely characterized by settler migrants (Sikder 2008). In contrast, the current phase of migration has drawn unskilled and semi-skilled workers to Middle Eastern countries as temporary migrants. The oil boom in the Gulf fuelled increases in the demand for labour, which was supplied by labour-surplus economies like Bangladesh and India.

Record keeping on this migration flow to the Middle East began only in 1978, after the independence of Bangladesh (Bureau of Manpower, Employment and Training 2016b). Women, however, remained unaccounted for in mainstream migration data until 1991. This is particularly problematic since women are more likely to represent short distance migration flows owing to factors like proximity, cultural and linguistic similarity, and ease of finding flexible employment at the destination (Asis 2003). Although Bangladeshi women might have gained access to certain migration channels in the early years of independence, a Presidential Order in 1981 barred semi-skilled and unskilled women from migrating alone to protect their dignity, following the demands of the Bangladeshi association of migrant workers in Kuwait. This was replaced with restrictions on the migration of unskilled and semi-skilled women workers in 1988, but exceptions were allowed in selected cases. In 1997, a blanket ban on the migration of women across all skill categories, except for highly skilled professionals like doctors, engineers, and teachers, was instated in the name of protecting women's dignity, but was lifted in December of the same year amidst heavy protests. It was argued that such policies were counter-intuitive to women's protection and development, and were unconstitutional and discriminatory in nature (Siddiqui 2001).

Although unskilled and semi-skilled migrants account for nearly go per cent of Bangladeshi women migrants, the government has continued to impose skill-based bans on the migration of women (Islam n.d.). In 2003, the Ministry of Expatriates' Welfare and Overseas Employment allowed semi-skilled and unskilled women above 35 years of age to migrate - but only after the agency recruiting them paid BDT five million (US\$70,850) as a security deposit to the government (Migrant Forum Asia 2014). Human Rights Watch observes that, although Bangladeshi migrant women are legally required to pay up to BDT 20,000 (US\$259) to the recruiter, in reality they often paid almost five times the amount (Human Rights Watch 2016). 
This overcharging makes the cost of legal migration from Bangladesh one of the highest in South Asia.

In recent years, the Government of Bangladesh has tried to correct the existing gender biases in the labour market. Continuing the corrective measures started in 2003, the Employment Act of 2011 reduced the age requirement for unskilled and semi-skilled women migrants to 25 years. However, remaining regressive clauses such as the requirement for an accompanying male guardian and continued skill-based bans on domestic workers are counterproductive for the integration of women migrants. The failure of state policies to recognize women as significant actors in the migration process has resulted in the burgeoning of a number of parallel irregular forms of migration. In fact, policies that seek to securitize borders and increase the burden of the 'illegality tax' on migrant populations without reflecting on structural problems at the origin or persistent inequalities in income levels often fail to curb irregular migration, as seen in the case of Bangladesh. ${ }^{2}$

The presence of large and porous borders and a shared colonial history and religious, linguistic, and ethnic spaces has made South Asia one of the major hotspots for undocumented migration in the world today. According to the 2001 Indian Census, Bangladeshis comprised almost 61 per cent of the total foreign population in India (Registrar General of India 2011). Although the number of additional migrants from Bangladesh to India has been decreasing since 1981, the long-established and thriving social network in India has been utilized by a steady stream of undocumented migrants in search of economic opportunities. Although the dominance of India as a destination for Bangladeshi women has steadily declined from 89 per cent in 1990 to 61 per cent in 2015, global data indicates that it still is the single largest destination for Bangladeshi women. ${ }^{3}$

India is the preferred choice for women migrating from Bangladesh (Blanchet 2010). The perceived abundance of work opportunities in urban India is one of the main pull factors for migrant labourers from borderland areas of Bangladesh (Kabeer 2007: 1). In India, most of the Bangladeshi migrants had initially clustered in the border regions, mainly in West

2 The illegality tax imposes the costs of migration on the employer recruiting migrants (Todaro \& Maruszko 1987).

3 According to statistics from United Nations Department of Economics and Social Affairs (UNDESA), out of 260,000 women migrants from Bangladesh, 150,000 were in India in 2013. Although this proportion has seen a considerable decline since 1990, it remains substantial (United Nations, Department of Economic and Social Affairs 2015). 
Bengal, Tripura, and Assam. ${ }^{4}$ This has resulted in the escalation of conflicts between the local and migrant populations (Weiner 2015, Cǒt'e \& Mitchell 2017). In due course of time many of them migrated to urban centres like Delhi and Mumbai in pursuit of higher potential earnings. This path has been established over the years as a favoured destination for migration by many irregular Bangladeshi workers who easily find employment in the huge informal economy in India. They are absorbed into the labour market due to their malleability and flexibility, willingness to work longer hours at cheaper rates than locals, and inability to unionize or organize (Joseph \& Narendran 2013). The vulnerabilities of the migrant women are multiplied when they seek to enter their work destinations without valid work permits, passports, or other documents and rely on extortive dalals or social networks for support (Hamada 2012). The lack of agency of Bangladeshi women relegates them to an inferior position even while they bargain for entry into the labour market in India.

Naila Kabeer notes that Bangladeshi women are often concentrated in informal-sector jobs like domestic work, rag picking, the garment industry, dance bars, and other entertainment-related occupations (Kabeer 2007). These sectors are typified by conditions of flexible specialization, organizing through sub-contracting, sweatshops, and home-based production systems; workers often do not fall under the purview of state regulations making them vulnerable and insecure in their occupations by not allowing them job and income security, inhibiting skill reproduction, and weakening their representation in the labour market (Chen 2012:1). This has led to increasing casualization and contractualization, a rise in self-employment and homebased activities, and the feminization of this labour force (Hensman 2011). When poor women enter such exploitative institutions, they usually have to depend on their physical labour to meet survival requirements. They are seldom offered the freedom to negotiate a price for their labour, or to opt out of the market if their desired wages are unmet. Instead, their inability to generate sufficient investible surplus keeps them locked in 'inequality traps' (Kabeer 2012). The presence of such inequality traps fragments the labour market, which are managed and filled by cheap and docile undocumented women workers.

4 Various studies have highlighted the presence of Bangladeshi migrants in the Northeastern Indian states of Assam and Tripura and the eastern state of West Bengal. Assam and Tripura have also seen severe violence due to the influx of Muslim Bangladeshis popularly termed as the 'sons of soil' conflict (Weiner 2015, Cǒt'e \& Mitchell 2017). 
Migrant women often face 'double segregation' at their destination, as they are concentrated into more feminized jobs than either male migrants or local women, sedimenting them into the lowest rungs of the local labour market (Benería, Deere, \& Kabeer 2012). This marginalization and invisibility within the informal sector further brings in a range of stratified occupational categories which makes them work in dirty, dangerous, and demeaning jobs that critically accentuate the vulnerabilities faced by them. Migrant Bangladeshi women, thus, do not only face vulnerability in the process of migration, which renders them invisible; they are also rendered vulnerable at their destination, where they become 'illegal' alien workers. For undocumented migrant women, such vulnerabilities are mainly characterized by low and uncertain wages, long working hours, deplorable working conditions, the risk of sexually transmitted diseases, sexual harassment, physical and mental abuse, and susceptibility to human trafficking. The constant 'race to the bottom' in the economic, social, and political lives of undocumented migrants makes them one of the most vulnerable sections in the Indian labour force.

\section{Disaggregating Vulnerabilities}

Economic migration can be a harrowing experience for the poor. Studies have established that migration can have both oppressive and liberating consequences (Piore 1979, Deshingkar 2017). The present discourse around migration and development, however, exonerates the process of migration from any negative consequences through a myopic focus on its development potential (de Haas 2012). Women experience migration differently than men. While economic reasons predominate men's migration decisions, for women, migration not only represents a way to escape poverty, but also implies economic empowerment, strengthened family incomes, and durable assets for the future (Siddiqui 2001). While men often find it easier to access legal and formal migration channels due to their relatively higher levels of social and human capital, women are often forced to depend on informal and circuitous routes due to limited human capital, low skill levels, and inability to cover the high costs of legal migration. Such problems are routine experiences for many undocumented women migrants, but the lack of institutional support means that most of these poor women have to fend for themselves in an alien environment. This section highlights the economic and non-economic vulnerabilities associated with migration by undocumented women. 


\section{Economic Consequences}

When policies do not recognize that women's migration also has economic potential, they leave women to fend for themselves. With the ushering in of global commodity chains, women have increasingly been sought by the global labour market as productive and economic agents. However, many women are unaware of the consequences of migration. They rely on the stories from return migrants or dalals to form a picture of their destination societies. They hope to access better income opportunities, higher possibilities of savings, and make initial capital accumulation for asset building. These were also the main reasons for migration among sixteen women ( 78 per cent) of the present sample. Most of the women among the sample population expected migration to ease their financial difficulties and provide higher and more stable incomes. Aspirations of being able to open their own businesses, build a house, save up for relatives' marriages, or provide better lifestyles for their children were some of the major reasons for migration. Women also aspired to significantly contribute to the economic and financial security of their households, even in cases where women were associational migrants. Often the high costs of social reproduction in urban areas and aspirations of providing durable human and capital assets for their children were the underlying reasons for women's entry into the informal labour force. Thus, for many women, even if migration across the border is a 'forced choice', it becomes one of the primary ways of ensuring a 'positive opportunity to save, accumulate capital, or invest in assets' (Mosse et al. 2002).

However, when such migration opportunities are accessed with incomplete or false information, women become susceptible to the various threats that are embedded within the process of undocumented migration. Return migrants and dalals tend to glorify the experience of migration by selectively narrating success stories. Women are often led on by false hope of a better life created by recruiting agents, or fall prey to the glitter of city lights. Sanara, a 28-year-old construction worker, stated:

I was led to believe that all my requirements would be taken care of in Mumbai. However, here I am only given bhaat-kapor ['maintenance money'] on a weekly basis. I know my Seth ['employer'] will only be able to pay me my wages after we finish this slab, which will take at least fifteen more days. My family back home needs money for a medical emergency. I don't know what to do. This is only the curse of my fate. 
The jobs available to undocumented migrant women in urban India are mainly in the informal sector, where women often take up reproductive roles associated with caring and nurturing, or work as cheap labour in the manufacturing sector, where their work is characterized by neglect, violence, and the progressive erosion of labour rights (Arya \& Roy 2006: 22). The marginal position of women in the stratified labour force is also reflected in the present sample, where seven women were found to be concentrated in construction (30 per cent), domestic work (30 per cent) and fish- and meatpacking (30 per cent) each, and two women in self-employment (9 per cent). Their working conditions and work-related vulnerabilities varied between the different occupations. While self-employed women were found to be significantly better off than others, with a mean income of INR 14,890 (US\$230) per month, women employed in the construction sector earned the least, at INR 5800 (US\$89) per month. Domestic workers earned almost INR 7800 (US\$120) per month; women engaged in food packaging earned INR 8350 (US\$128) per month. The stark inequalities in remuneration across the different sectors are a reflection of the ease of access to and gendered division of work in each occupation. While self-employment is obviously the most remunerative, it requires a strong base of financial and social capital, which might not be accessible to poor women. Packaging and domestic work largely draw on women's labour because of their gender-differentiated requirements. While the 'nimble fingers' 5 debate (Elson 1996, Crowley 2013) dominates the packaging industries, domestic work has largely been the domain of female workers. Women are also incorporated as secondary, cheap workers in the largely male construction sector, making it difficult for women to access skills training and higher wages.

During my research, I encountered evidence of gendered economic and non-economic coercion in the informal labour market in Maharashtra. It was found that women worked longer hours than men on average, with less time for breaks. The flexible working hours for women engaged in domestic work are a reflection of their lack of control over their working lives. Razia, a domestic worker in Navi, Mumbai, examined her work life as follows: 'Where will I go if I do not go to work when they [my employers] want me to work? I start work at 6 AM every morning and I am generally done by 2 PM. My mornings are extremely busy as I have to finish work before my employer leaves for her work at 9 AM. I cook for my family only after I come back from work.'

5 The nimble fingers debate refers to the docility of women and child workers especially in labour intensive occupations that require higher speed, greater attention to details and patience for monotonous jobs (Crowley 2013). 
Among the participant sample, it was observed that domestic workers had the longest and the most flexible work schedules, but they often have to be tweaked to suit the needs of their employers. Fifty-eight per cent of the domestic workers reported that they worked for more than eight hours per day without any significant breaks. It was relatively easier for women engaged in the construction and packaging sectors to anticipate their work routines, and they had fixed lunch and refreshment breaks. Women in the packaging sector generally worked in eight-hour shifts in the early morning, afternoon, or night - but they had to agree to work during any of the shifts. The majority of women construction workers (94 per cent) worked for less than eight hours at fixed times during the day, and also had an assured break of one hour for lunch and rest. The regularity of the work schedules in the construction sector is a reflection of the stronger bargaining position that male workers have vis-à-vis women workers, while women-dominated sectors like domestic work have no fixed hours for work and breaks.

Women-dominated sectors are also prone to drudgery, low skill enhancement, limited bargaining capacities, and fewer social security provisions. Since informal sector jobs are based on loose contracts, low protection from exploitation, insecure employment conditions, and limited upward mobility, women often are caught in vulnerable positions. In the sample population, most women workers (79 per cent) had a verbal contract with their employer. However, these contracts are only used to demarcate the duties of the workers and provide no scope for bargaining for their rights in the workplace. At least 19 per cent of all the sampled workers had no contract at all. None of the Bangladeshi migrant women had access to any written documentation of their employment contracts, making them particularly susceptible to malpractice by their employers, such as paying lower wages than agreed, or working odd and long hours. The lack of labour market security also extends to unpaid overtime, a lack of perks in the workplace, and an overall lack of control of their working lives. Out of the total sample population, only 28.3 per cent of the workers had received overtime payments. Most women had no control over deciding their wages or work schedule. In 34 per cent of the cases, the employer decided the wages; another 34 per cent used existing market information to determine how much to ask for. Women's wages in the industrial sector were generally fixed by the recruiting agents, and they were compelled to work at the given wages without any opportunity to bargain. Shanti, the recruiting agent for fisheries, explained: 
I make sure my girls are paid well. Girls working for packaging are given INR 6500 (US\$95) monthly and for grading they receive INR 7500 (US\$110). I have made sure that my girls also get paid overtime at the rate of INR 20 (US\$0.29) per hour. They are also given two pairs of dresses and hairnets by the company annually. After every ten months of work, the company pays them a month's salary as bonus without doing any work so that they can go home. It also provides train tickets for the journey.

Her words, meant to portray the firm's benevolence, in fact bring out the politics of the industry and how the companies circumvent legal requirements to keep workers entrenched in informal work conditions by refusing to list them on their payrolls for more than ten months at a time - the period required by law to start providing social and employment benefits like provident funds, insurance, and gratuity.

In addition, undocumented migrant women workers often lack opportunities for collectivization and unionization because local labour unions rarely support their cause. This lack of access to basic labour rights often snowballs into other disenfranchisements, such as the lack of a proper savings mechanism, overt reliance on employers for health and other social benefits, and a lack of access to secure remittance channels that makes women depend on untrustworthy middlemen or social networks. Weak remittance mechanisms and hawala' ('transfer of funds through informal channel') transactions remain the primary ways migrants remit their incomes. Since this process involves significant fees, many migrants among the sample population preferred to remit lump sum amounts at once, which makes them susceptible to larger losses if the transaction is not successful. Among the sample population, women migrants showed a greater propensity to save than their male counterparts. Women were also more likely to invest their savings in creating additional human capital and providing for their daily consumption expenditures than male migrants were.

Migrant women are often subjected to the whims and fancies of their employers who seek the feeblest excuses to discipline them. Arbitrary deductions in wages or non-receipt of payment are some of the biggest threats. Shabana, for example, was promised INR 300 (US\$4.50) for every

6 The hawala system of transfer of remittances from one country to another involves the migrant paying in one currency to an agent at the destination, which is paid to the intended beneficiary at the origin in the local currency by another agent. This transaction occurs informally and some scholars have termed it as money laundering. (Doherty et al, 2014). 
twelve hours she worked. However, she was paid only INR 7000 (US\$103) at the end of the month; her employer told her that she had exceeded the allotted 30 minutes for breaks and therefore her wages had been cut. For many migrant women, the threat of arbitrary dismissal is an effective deterrent towards unionization or raising their voice against injustices at work. It also prohibits them from seeking wage advancements, as they cannot break the gender-differentiated ceiling of the wages at their workplace. For example, Fatima had been working for the same employer for the last three years, but her daily wage had only increased from INR 100 (US\$1.50) to INR 250 (US\$3.70). Her husband's daily wage increased threefold during the same period, from INR 200 (US\$3) to INR 600 (US\$9). Since no Maharashtrian trade union takes up the cause of undocumented immigrants, they become invisible workers and their grievances often remain unheard or are presented from the employers' perspective where they are portrayed as 'infiltrators and criminals' who come here to 'loot' the Indian economy.

\section{Social Consequences}

Migration results in overwhelming changes in the life worlds of migrants and exposes them to different realities through uprooting them from the social and structural ties of traditional society (Gardner 2009). The experience of migration also alters their perception of selfhood through entry into the workforce. Thus, migration brings not only economic vulnerabilities but also changes in the personal, social, cultural, and political aspects of migrants' lives. Migration is, for example, the first time many women undertake paid work. The continued dominance of patriarchal beliefs in Bangladesh ensures that women's participation in paid employment is frowned upon and considered a sign of the inability of a husband to provide for his wife (Blanchet 2010). When women undertake paid employment at far-away destinations, families can absolve themselves of any stigma that would normally be associated with using the income of female members of the households. This changes not only the intrinsic self-worth of women, but also their social and inter-personal interactions. This is evident from the words of Ruksana, a domestic worker, who stated:

I never thought I would be in Mumbai ever in my life. Here I go out to work and sometimes earn more than my husband [who is a construction worker]. He often cooks for me when I am too tired from my work. He would never have done this in the village. 
Among the participants in the present study, only 31 per cent of the women had work experience in domestic work, brick kilns, readymade garments, or agriculture before migrating to India. Even among these previously employed women, migration to Maharashtra denoted a greater and relatively more regular source of earnings than was available in Bangladesh. Arshiya, a 19-year-old widow, recounted her economic condition after the death of her husband to me. With her mother-in-law refusing to feed her and her one-month-old son, she was employed as domestic help in her husband's uncle's house. She found this arrangement coercive and demeaning since she was bound by familial relationships and could not complain about lost wages or inconsiderate behaviour from her husband's relatives. She says that she took that work because there was no other way to feed herself and her son. Although her job at a construction site in Maharashtra involved strenuous work, she felt that she enjoyed a greater degree of freedom and was much more in control of her life than she had been in Bangladesh.

Migration also brings about changes in the attitudes of migrants as they are exposed to new traditions and cultures. This is especially evident in the case of women migrants who have no previous experience of migration. For example, Fatima lived with her husband and three other young men from her village at the construction site where they worked. Since the other men did not have their families with them, she cooked for everybody for a small fee. She often rode pillion on her Seth's ('employer's') motorcycle to reach other sites for work, and she stated that her husband would probably not have allowed her to behave so freely in their village.

Migration affects the interaction between the individual and society in the most fundamental ways. A widely reported consequence of migration among the participants of this study was the sense of 'not-belonging'. Migrant women are often forced into seclusion to make them invisible at their destinations. Such practices ensure their anonymity and keep them hidden, but also lead to significant risks as they are enforced through slave-like conditions and exclusion. For example, the women working in the packaging industry were provided with hostel facilities by their employers within the premises of the factory. They were accommodated in bunk beds in a big room and had access to free food and television in their spare time. However, they were not permitted to leave the factory premises except for two hours every week or in extreme emergencies. The recruiting agent ensured that all of the women complied with this rule, supposedly to keep them 'safe' at the destination. 
The sense of loneliness was strong among most of the women workers who migrated alone or without their families. This is evident in the case of Khatiba, a 24-year-old worker in the packaging industry who was away from her husband and children for the first time in her life. She was constantly anxious about the well-being of her family back in the village, but knew that worrying about them would not help. She instead chose to concentrate on her work and count the days until she could meet them again. For her, talking over the phone with her five-year-old son did not provide much comfort.

Although with the use of telephones migrants can regularly keep in touch with their natal and marital homes in Bangladesh, the sense of being away overpowers many. One migrant woman, for example, had to quit her employment in Maharashtra because she could not stay away from her daughter. Since most jobs in the informal sector do not provide crèches or other facilities for children, most women migrants have to leave their children back home. For undocumented Bangladeshi migrants, bringing their children would mean giving up on their education; admission in Indian schools requires a certificate of birth in India or legal migration papers. Since these cannot be arranged for, children often grow up with their grandparents or other relatives in Bangladesh while the migrant couple or women remit money from abroad. Migration increases the distances between people and spaces. Most migrants cannot attend to sudden illnesses or deaths in their families in the villages. When Fatima, a construction site worker, learned that her mother-in-law had been diagnosed with cancer, she and her husband were unable to go back to the village until they managed to save BDT 150,000 (US\$1900) to repay their debts taken there.

Most migrants are bereft of social lives such as those they enjoyed in their villages. Moreover, with exclusionary living conditions at their destination, they are barred from social interactions even in the destination societies. During the course of data collection, many participants in the study reported that they felt happy to talk to someone in Bengali in bidesh ('the foreign land').

\section{Cultural Consequences}

Linguistic and religious barriers are two of the main problems faced by migrant women. Most migrants from West Bengal and Bangladesh do not speak the local languages of the destination regions, and this becomes an additional factor in their exclusion there. Surekha, a domestic worker, previously lived in the southern Indian state of Andhra Pradesh. She recalled her initial difficulties in communication: she was often left alone without the ability to have a conversation with anyone after her husband went to 
work. By the end of her two-year stint in Andhra Pradesh, she had picked up some words because, as she put it, 'it is impossible to survive otherwise'.

Most migrants also feel bereft of their religious practice. Since women are not allowed to enter mosques in Bangladesh, it does not generally bother them to live in remote locations where there are no mosques. However, many employers in Maharashtra are Hindu, and it is difficult for them to practice Islam like they would at home due to the long working hours and the strenuous nature of their work. For example, none of the Muslim migrant women I interviewed were able to fast during the month of Ramadan, as doing so would make it difficult to work. While most employers understood that Ramadan Eid (Eid-al-Fitr) and Bakri Eid (Eid-al-Adha), the two main Muslim festivals, had to be declared holidays, this in turn meant that they had to work on most of the Hindu holidays.

\section{Political Consequences}

The presence of a strong anti-migrant lobby in Maharashtra makes undocumented migrants vulnerable in the political sphere. The refrain of 'infiltrators' and 'terrorists' used to refer to any Bengali-speaking Muslim often makes it imperative for Bangladeshis to hide their political views and become excluded politically (Rai 2014). In Maharashtra, according to a newspaper report, 'any Bengali speaking Muslim is believed to be a Bangladeshi infiltrator' (Vijapurkar 2016). This discourse about 'infiltrators' was brought to a different level altogether when the Chief Electoral Officer of the state declared that Mumbai hosted 40,00o Bangladeshis - a number arrived at by looking at the number of people in Mumbai who failed to provide documents that could prove them to be Indian. Vijapurkar terms this a 'tragicomic instance' of the role of media (Vijapurkar 2016).

In the context of this ongoing diatribe against Bangladeshis, many of the recent migrants have managed to obtain original Aadhar cards by paying agents a fee of about INR 2000 (US\$29). 7 They understand that Aadhar is not the proof of citizenship, but it does still provide a documentary evidence of 'Indianness'. On the other hand, there are Bangladeshi migrant workers living in urban Maharashtra for more than 30 years without any documentary evidence of their citizenship in India. Although they claim that they are as Indian as anyone else, this lack of documentation makes them vulnerable to threats of arbitrary imprisonment and deportation.

$7 \quad$ Aadhar cards provide a unique identification number to their holders and link them with many social security provisions provided by the Indian government. 


\section{Conclusion}

The working and living conditions of Bangladeshi women in India reveal that undocumented migration is a double-edged sword. While they become economically independent and are able to successfully contribute to the economic requirements of their households, they often also take on far greater risks than male migrants do. The vulnerabilities that women migrants face both in Bangladesh and India attest to strategies of state where the labouring rights of individuals are overshadowed by the state's concerns about legitimacy and border control. Developing countries like Bangladesh seek to create a niche for themselves in the global commodity chain as a source of cheap labour resources through migration, but at the same time coercive controls over women's mobility do not allow women to access migration opportunities. This leads to conditions where the destination economies benefit from 'the comparative advantage of women's disadvantage' (Pagaduan 2006).

As vulnerabilities are interspersed throughout the migration process, women migrants face a breakdown of their freedom of agency at multiple levels. Christine Koggel argues that women's agency is vital not only for improving their economic and social positions, but also for challenging the embedded, patriarchal social values and practices that support long-term gender biases in the social sphere (2007). In the present era of globalization, undocumented women migrants comprise one of the numerous vulnerable social groups whose economic integration is predicated on their willingness to forego a spectrum of socio-political and cultural rights. The role of the state in furthering this vulnerability is especially significant because its myopic vision of women's 'safety' makes migration a highly gendered experience at both the origin and destination points.

Women's agency in migration can be understood as a series of interconnected threshold capabilities that reduce the gender gaps at both the societal and state levels to allow women to determine and choose which capabilities remain central to them. This can be achieved through overarching changes in the marginal position of women in accessing property rights, the gendered division of labour within the household, and the influences of patriarchy at both the origin and destination, all of which contribute to limiting women's freedoms and capabilities. When such divisions are also upheld and reflected by political and economic institutions, they provide the starting point for injustice and limit valuable functions that would have been accessible to women otherwise. Women's migration can be seen as a process that not only provides economic freedoms, but also strengthens women's political, social, and cultural freedoms. 


\section{References}

Arya, S. and Roy, A. (2006). When poor women migrate: Unravelling issues and concerns. In: S. Arya and A. Roy, eds., Poverty, Gender and Migration. New Delhi: Sage, pp. 19-48.

Asis, M.M. (2003). When men and women migrate: comparing gendered migration in Asia. In: United Nations Division for the Advancement of Women (DAW) Consultative Meeting on Migration and Mobility and How this Movement Affects Women. Sweden: Malmo, pp. 2-4.

Benería, L., Deere, D., and Kabeer, N. (2012). Gender and international migration: Globalization, development, and governance. Feminist Economics, 18, pp. 1-33.

Blanchet, T. (2010). Migration to the bars of Bombay: Women, village religion and sustainability. Women's Studies International Forum, 33(4), pp. 345-353.

Bureau of Manpower, Employment and Training (2016a). Overseas Employment and Remittances from 1976 to 2016. Dhaka: Ministry of Expatriates' Welfare and Overseas Employment.

Bureau of Manpower, Employment and Training (2016b). Overseas Employment of Female Workers from 1991 to 2016. Dhaka: Ministry of Expatriates' Welfare and Overseas Employment.

Chen, M. (2012). The informal economy: Definitions, theories and policies. Working Paper No. 1, Manchester: Women in Informal Economy Globalizing and Organizing (WIEGO).

Crowley, M. (2013). Gender, the Labour Process and Dignity at Work. Social Forces, 91(4), pp.1209-1238.

de Haas, H. (2012). The migration and development pendulum: A critical view on research and policy. International Migration, 50(3), pp. 8-25.

Deshingkar, P. (2017). Towards contextualised, disaggregated and intersectional understandings of migration in India. Asian Population Studies, 13 (2), pp. 119-123.

Doherty, M., et al, (2014). Understanding South Asian Labour Migration. Workshop in International Public Affairs. Madison: University of Wisconsin-Madison.

Elson, D. (1996). Appraising recent developments in the world market for nimble fingers. In: Confronting State, Capital and Patriarchy. London: Palgrave Macmillan, pp. 35-55.

Gammage, S., Kabeer, N. \& Rogers, Y. (2016). Voice and agency: Where are we now? Feminist Economics 22(1), pp. 1-29.

Gardner, K. (2009). Lives in motion: The life-course, movement and migration in Bangladesh. Journal of South Asian Development, 4(2), pp. 229-251.

Hamada, Y. (2012). National governance in international labour migration. Migration and Development, 1(1), pp. 50-71.

Hensman, R. (2011). Workers, Unions, and Global Capitalism. New York: Columbia University Press. 
Hujo, K. and Piper, N. (2010). South-south Migration. New York: Palgrave Macmillan. Human Rights Watch (2016). Bangladesh:Improve Protections for Migrant Domestic Workers. London: Human Rights Watch.

Islam, M. (n.d.). Study on women migrants situation: Profile of women migrants, causes, problems and prospects of migration. [online] http://www.bmet.gov. bd/BMET/resources/Static\%2oPDF\%2oand\%2oDOC/publication/Gender\%2o Analysis\%20of\%2oMigration.pdf

Joseph, J. and Narendran, V. (2013). Neither here nor there: An overview of southsouth migration from both ends of the Bangladesh-India migration corridor. ISS Working Paper No. 569, The Hague: International Institute of Social Studies of Erasmus University Rotterdam (ISS).

Kabeer, N. (2007). 'Footloose' female labour: Transnational migration, social protection and citizenship in the Asia region. IDRC Working Papers on Women's Rights and Citizenship, Ottawa: IDRC.

Kabeer, N. (2012). Women's economic empowerment and inclusive growth: Labour market and enterprise development. DFID-IDRC Discussion Paper 29/12, London: Centre for Development Policy and Research.

Koggel, C. (2007). Globalization and women's paid work. In: B. Agarwal, J. Humpries, and I. Robeyns, eds., Amartya Sen's Work and Ideas: A Gender Perspective. Oxford: Oxford University Press, 180-202.

Migrant Forum Asia (2014). CEDAW and the Female Labour Migrants of Bangladesh. Manila: Migrant Forum Asia.

Mosse, D., Gupta, S., Mehta, M., Shah, V., Rees, J.F., and Team, K.P. (2002). Brokered livelihoods: Debt, labour migration and development in tribal western India. Journal of Development Studies, 38(5), pp. 59-88.

Pagaduan, M.C. (2006). Leaving home: Filipino women surviving migration. In: S. Arya and A. Roy, ed., Women and Migration in Asia. New Delhi: Sage, pp. 72-86.

Peter, F. (2005). Gender and the foundations of social choice: The role of situated agency. In: B. Agarwal, J. Humpries, and I. Robeyns, eds., Amartya Sen's Work and Ideas: A Gender Perspective. Oxford: Oxford University Press, pp. 17-38.

Piore, M. (1979). Birds of Passage. Cambridge: Cambridge University Press.

Rai, S. (2014). Bangladeshis must leave or turn Hindu: Bajrang Dal. The Times of India. 23 December.

Ramachandaran, S. (2002). Suicide, just another way to fight in Kashmir. Asia Times, 24 July.

Registrar General of India (2011). West Bengal Religion Census. New Delhi: Census of India.

Sen, A. (1977). Rational fools. Philosophy and Public Affairs, 6, pp. 317-344.

Sen, A. (1985). Well-being, agency and freedom.Journal of Philosophy, 82, pp. 169-221. 
Siddiqui, T. (2001). Transcending Boundaries: Labour Migration of Women from Bangladesh. Dhaka: The University Press Limited.

Sikder, M. (2008). Bangladesh. Asia and Pacific Migration Journal, 17(3-4), pp. 257-275. Todaro, M. and Maruszko, L. (1987). Illegal migration and US immigration reform: A conceptual framework. Population and Development Review, 13(1), pp. 101-114. United Nations, Department of Economic and Social Affairs, Population Division (2015). International Migration Flows to and From Selected Countries: The 2015 Revision (POP/DB/MIG/Flow/Rev.2015).

Vijapurkar, M. (2016). The illegals: Mumbai's Bangladeshis. [online] Rediff. Available at: http://news.rediff.com/column/2010/feb/24/the-illegals-mumbaisbangladeshis.htm

Weiner, M. (2015). Sons of the Soil: Migration and Ethnic Conflict in India. New Jersey: Princeton University Press.

World Bank (2016). Female headed households in World Development Indicators, [online] World Bank, Available at: https://data.worldbank.org/indicator/SP.HOU. FEMA.ZS?end=2014\&locations $=$ BD\&start $=1994 \&$ view $=$ chart

\section{About the Author}

Ananya Chakraborty is a doctoral student at the School of Development Studies, Tata Institute of Social Science, Mumbai, India. Her current work explores the themes of gender, labour, and migration within the South Asian context. Broadly, her areas of interest include gender, migration policy, and human development. 



\title{
6 'The Immoral Traffic in Women'
}

\author{
Regulating Indian Emigration to the Persian Gulf
}

Andrea Wright

Jones, Reece and Ferdoush, Md. Azmeary (eds), Borders and Mobility in South Asia and Beyond. Amsterdam: Amsterdam University Press, 2018 DOI: 10.5117/9789462984547/CHo6

\begin{abstract}
This chapter draws on ethnographic and archival research conducted in the United Arab Emirates and India to investigate how the Indian government developed and implemented emigration policies. The chapter is specifically concerned with how the idea of 'vulnerable subjects' is constructed in conjunction with trafficking. Bringing together contemporary and historic narratives on trafficking, it examines how gender, sexuality, and religion influence contemporary laws. The chapter pays particular attention to how the British colonial administration used trafficking as a way to regulate both women's labour and their movement, and it compares this approach with the attitudes of Indian nationalists. In the postcolonial period, it draws on a case study from the 1950s concerning the illegal trafficking of women. The chapter argues that these policies unevenly impact working class and, particularly, Muslim women. What emerges is the uneven distribution of state power as bureaucrats restrict emigration.
\end{abstract}

Keywords: trafficking, gender, Muslim, British colonialism, Indian nationalism, Persian Gulf

\section{Introduction}

The labour conditions of workers in the Arabic-speaking Persian Gulf are under considerable scrutiny, and domestic workers are thought to be particularly vulnerable. ${ }^{1}$ Recently, Amnesty International found that some domestic

1 The countries of the Arabic-speaking Gulf are Bahrain, Kuwait, Qatar, Saudi Arabia, the United Arab Emirates, and Oman. 
workers are abused, over-worked, and not compensated for their work (Amnesty International 2014). Transnational institutions, such as Amnesty International and the United Nations Office on Drugs and Crime (UNODC), argue that a central contributing factor to the abuse of domestic workers is the prevalence of trafficking in the Arabian Sea. Trafficking of persons to the Gulf countries, according to the United Nations, leads to the exploitation of workers' physical and sexual labour (United Nations Committee on the Elimination of Discrimination Against Women 2014). In the worst cases, poor women from South Asia or the Philippines are recruited to work in the Gulf by people who promise them good paying jobs. In these scenarios, after women arrive in the Gulf, they are treated poorly by their employer and not paid for their work. They are unable to return to their home countries due to a lack of funds, the large amounts of debt borrowed to pay for their emigration, and/or physical restrictions on their movements from their employers. In discussions by Amnesty International and other nongovernmental organizations, the exploitation of trafficked women is often explained as largely the result of the practices used to exclude non-citizens in the Arabic-speaking countries of the Persian Gulf. ${ }^{2}$ In response to the potential abuse of domestic workers and building upon historic laws developed to protect 'vulnerable' migrants, the Indian government enforces emigration procedures that aim to decrease the number of trafficked persons travelling to the Gulf.

In 2009, I began a research project examining the migration of Indians to the Arabic-speaking Persian Gulf. 3 This project looks at how workers find jobs in the Gulf and how potential migrants negotiate emigration regulations. During the course of my research, I followed some of the almost one million workers travelling annually to the Gulf: I met them in villages in rural India and then followed them to recruiting agencies in Mumbai or Hyderabad, and onward to positions in the Gulf. ${ }^{4}$ Due to Indian government

2 An increasing number of scholars have focused on the experiences of migrant workers and how these experiences are connected to citizenship practices in the Gulf. The unique relationship between citizenship and Arabness in the Gulf continues to be debated (Gardner 2010; Limbert 2014; Vora \& Koch 2015; Wright 2015).

3 This paper is based on ethnographic and archival research I conducted in India, the United Arab Emirates, and at private archives beginning in 2006 and continuing to the present. From 2009 to 2011, I conducted continuous research in India and the United Arab Emirates funded by the Fulbright Hayes Doctoral Dissertation Abroad Award. I am also indebted to Aligarh Muslim University, the Dubai School of Government, and, especially, the University of Michigan. These universities provided additional financial and institutional support for this project.

4 In 2012, over 720,000 men who required emigration clearance migrated to work in one of the countries of the Arabic-speaking Persian Gulf. Because only the least educated emigrants require emigration clearance, hundreds of thousands of additional migrants travel to the 
regulations regarding emigration, most of the unskilled or semi-skilled workers I met found jobs through recruiting agents. These agents act as middlemen between companies in the Gulf and potential employees. To learn about the migration process, emigration laws, and the actors involved, I travelled throughout Mumbai and visited some of the over three hundred recruiting agencies located in the city. As I visited these recruiters, I realized that recruiting offices were highly gendered spaces: most of the owners and employees of the recruiting agencies were men. What I found most surprising, however, was that there were no women looking for work abroad in these agencies. Postings for work in the Gulf would draw hundreds of Indian men for interviews, but I never, in over two years of research, ran into a woman looking for work in the Gulf at a recruiting agency.

As I met with recruiting agents, I learned that they were often reluctant to facilitate the migration of working-class women due to popular perceptions that working-class women are trafficked to the Gulf for sexual exploitation. This chapter examines how emigration policies are constructed as the Indian government attempts to protect vulnerable women and the consequences of these laws on women's ability to migrate. To understand the multiple approaches to trafficking that impact current emigration practices in India, I look at how trafficking is perceived and publicly narrated in the contemporary moment. I then trace how the idea of trafficking was constructed historically. I pay particular attention to how the British colonial administration used the concept of trafficking as a way to regulate both women's labour and their movement, and I contrast this approach with the attitudes of Indian nationalists and later postcolonial bureaucrats. Using a case study from the 1950s concerning the illegal trafficking of women, I examine how the contemporary restrictions on emigration developed from colonial and postcolonial practices. I argue that these policies unevenly impact working-class women and, particularly, Muslim women. What emerges from this conversation is the uneven distribution of state power as bureaucrats attempt to restrict emigration.

\section{Migration and Morality}

The lack of women in the recruiting agencies I visited surprised me, given that approximately 20 per cent of the Indian workers in the United Arab Emirates (UAE) are estimated to be women (Zachariah, Prakash, \& Rajan 
2004: 2229). Having spent time in the Gulf, I knew that a common job for an Indian woman was working as an aaya ('nanny') or domestic worker. In an attempt to understand how women migrated to the Gulf, I began looking for and trying to meet women in India who were looking for jobs there. When I met recruiting agents, I asked if they facilitated the migration of women. This was not an easy topic to broach, and it required me to perform a certain tact so that agents would not think I was suggesting they participated in unsavoury business practices. For example, when I first began my research, I asked bluntly if agents helped place women in jobs as domestic workers, food servers, or salespersons in the Gulf. My poorly framed questions provoked offended responses from the recruiting agents, and they would express moral indignation that I would ask such questions of them. One of the reasons for this moral offense was the assumption that working-class Indian women in the Gulf must be trafficked persons. Agents explained to me that women who migrated in search of unskilled labour, in particular, were exploited and forced to work in the sex industry.

I had one such awkward conversation with Mr. Mohammad, an owner of a recruiting agency in Mumbai. ${ }^{5}$ I first met Mr. Mohammad at an association meeting for recruiting agents, and he immediately invited me to his office. About a month later, I ventured to a small office park located in the suburbs of Mumbai. I sat drinking tea and Mr. Mohammad explained to me the current jobs for which he was interviewing workers. As we talked, we were repeatedly interrupted by men who wanted to drop off their resumes, receive updates on recent interviews, or learn if there were any upcoming job interviews. I asked Mr. Mohammad why there were never any women looking for work at the recruiting agencies I visited. He responded by explaining that only 'unscrupulous' agents work with women. The reason, he continued, was 've faydain utha raha hain', or 'they [unscrupulous agents] take advantage [of women]'. In particular, he said, it was commonly known that women would be sexually exploited while in the Gulf. Given the predominance of this knowledge, he assumed that a woman who wanted to work in the Gulf could best be characterized as achchhee larki kitara nahin or 'not the good type of girl'. This euphemistic expression was used not only by Mr. Mohammed, but also by other recruiting agents with whom I spoke. The phrase was meant to convey that women, and particularly uneducated women, who wanted to travel abroad must be sexually promiscuous.

5 The names of individuals, with the exception of politicians acting in their official capacity, have been changed. 
Newspapers also repeated this view that sexually promiscuous women migrate to work in the Gulf, and Indian women working in the Gulf as entertainers faced particular scrutiny. While I was conducting my research, newspapers frequently ran articles concerning Indian 'dancing girls' working in the Gulf (Lall 2009; DNA Investigations Bureau 2011). In these articles, reporters interviewed 'concerned patrons' who claimed that 'girls ply the trade' - meaning that women dancers were also selling sex. Patrons supported this claim by stating that performers were not allowed to take tips and, therefore, the only reason to dance well would be to entice clients. In these articles, the Gulf was portrayed as a place where unskilled women could make large amounts of money, but only by participating in the sex industry.

In both newspaper accounts and the stories told to me by recruiting agents, working as a sex worker was considered inherently exploitative, and working-class women were particularly vulnerable to this type of exploitation once they travelled outside of India. ${ }^{6}$ This understanding of sex work and coercion is strikingly similar to the Immoral Traffic (Prevention) Act, which was passed by the Indian government in 1956 and amended in 1986. One of the original reasons for writing and implementing the Act was the United Nations' work against trafficking. In the Immoral Traffic (Prevention) Act, 'prostitution', defined as 'the sexual exploitation or abuse of persons for commercial purposes or for consideration in money or in any other kind', is conflated with trafficking (Government of India 1956, section $2 \mathrm{f}$ ). This association between trafficking, sexual labour, gender, and class means that recruiting agents are reluctant to help facilitate women's migration, as they do not want to be seen as profiting from women's sexual exploitation.

In the stories about women migrants to the Gulf related by newspapers, government bureaucrats, and agents, the emigration of uneducated women is linked to their potential sexual activity and the commercialization of sex. Even though there are a wide variety of experiences reported by women working in the Gulf, the intersection of sex work, class, and migratory status meant that women were left rapidly vacillating between an excess and absence of sexuality. ${ }^{7}$ This is seen in the two most common characterizations of working-class women migrants. The first is that these women are of loose morals', and they participate in sex work for financial gain. The other is that

6 In her discussion of Indian women working in call centres, Reena Patel points out that educated women working in non-traditional jobs has not led to greater gender equality in India (Patel 2010). 7 For example, Anna Stirr discusses the wide variety of experiences of female performers in Dubai's nightclubs (Stirr 2017). 
Indian women who are of a morally high character, and therefore generally sexually unavailable, are forced to participate in the sex trade when they travel to the Gulf. ${ }^{8}$ This tension between promiscuity and purity restricts the possibilities for female emigration. Because working-class women are thought to have limited options outside of sex work, all emigration by poor women becomes suspect. As working-class women are envisioned and treated as potential victims of sexual predation, their vulnerability means that the state needs to protect them by regulating the emigration process. For recruiting agents, government officials, and newspaper reporters, trafficking is the means by which women are coerced into sex work. The result is that the discursive power of trafficking both categorizes working-class Indian woman as vulnerable and constrains their ability to emigrate.

To protect vulnerable citizens, women who have not graduated from Class $\mathrm{X}$ face legal impediments to overseas migration. In fact, according to the Emigration Act of 1983 , it is impossible for an uneducated woman under 30 years of age to migrate to the Gulf for work. The order that prohibits these women from travelling abroad for work reads, 'Women below the age of 30 years may not be granted emigration clearance, who seek any kind of employment including employment as housemaids, domestic workers, hair dressers, beauticians, dancers, stage artist, labourers, general workers, etc. in any foreign country' (Government of India 1983). This policy, according to Didar Singh, the Secretary of the India's Ministry of Overseas Indian Affairs from December 2009 to November 2011, is not based on the Indian government's desire to interfere with migration. Rather, Dr. Singh told me, emigration regulations are because the government 'only wants to protect the most vulnerable of workers'. With the goal of protecting these workers, the Indian government regulates both emigration and recruiting agent activities.

In addition to these national policies, Indian states have recently attempted to implement laws that would regulate emigration and discourage trafficking. During my time in Mumbai from 2009 to 2011, recruiting agents were particularly concerned about the Government of Punjab's proposed Prevention of Human Trafficking Act, 2008. This proposed legislation placed the blame for trafficking on recruiting agents:

8 This construction of Indian women as innocent victims of trafficking neatly fits into what Diana Tietjens Meyers calls the 'pathetic victim paradigm'. Central to this paradigm is the idea that these victims did not consent to their treatment. As Meyers argues, there are a couple key drawbacks to understanding victims in this way. First, the pathetic victim paradigm can only work if the trafficked women are passive victims and women lose their agentive power. This focus on innocence and passivity also does not permit an understanding of how more complicated actors are also victims (Meyers 2011). 
Innocent/illiterate/gullible persons fall in the trap of unscrupulous persons who allure and induce such persons with false promises to send them abroad by charging heavy amount of money. But thereafter these persons are exploited by these elements for their illegal monetary gains by giving them false assurances for arranging their visas to foreign countries in general and advanced countries like Canada, USA, UK etc. [sic] particular. (Government of Punjab 2008)

This proposed state legislation has many similarities with the United Nation's definition of smuggling of migrants. ${ }^{9}$ Recruiting agents believed that the proposed act by the Punjabi state contradicted the Emigration Act in place at the federal level. The result was that the facilitation of some types of migration became fraught for agents. Agents feared the vague wording of the proposed state law would be used to imprison or levy large fines against them because both smuggling and trafficking were thought to be caused by people who misled vulnerable individuals for their own financial gain. In this approach to trafficking, the problem is neither labour laws nor sex work. Rather, the recruiting agent or smuggler is the root of the problem.

In the view of many Indians, recruiting agents are central to the poor treatment of workers in the Gulf. ${ }^{10}$ My neighbours and acquaintances in India were surprised that I would spend time with such undesirable people. It was common to refer to recruiting agents as 'racketeers' who are 'sending unskilled workers abroad for a life of misery' (Banerjee 2010). Given the increased attempts (starting from 2000 and continuing to the present) to stop trafficking at both the national and the state levels and the conflation of working-class women emigrants with sex workers, it is not, with the perspective gained by hindsight, surprising that the recruiting agents I met in Mumbai did not help facilitate the migration of women to the Gulf. Because large, established firms with connections to legitimate companies in the Gulf feared legal or moral reprisal, women who wanted to emigrate for work were left relying on less reputable firms. This contributes to a cycle in which the women who do migrate are more likely to go through irregular means, thereby opening themselves to more possibilities of trafficking.

9 In 2001, the United Nations' General Assembly passed the United Nations Convention against Transnational Organized Crime. This resolution defines smuggling of migrants as 'involves the procurement for financial or other material benefit of illegal entry of a person into a State of which that person is not a national or resident' (United Nations 2000, Article 13).

10 For example, S Irudaya Rajan et al. 2010 argue that corruption arises in the migration process from a 'nexus formed between erring government officials and recruiting agents.' In addition, Nasra Shah finds that workers who migrate without recruiting agents earn higher salaries and state they are happier with their jobs in the Gulf (2000). 


\section{Discourses of Trafficking}

Trafficking in the Arabian Sea is considered a pressing issue: the Gulf countries face scrutiny for their treatment of labourers, and South Asian countries, particularly India, are the source, destination, and transit countries of trafficked persons (US Department of State 2015). Despite the popular discourse that imagines trafficking as the movement of South Asians to the Middle East, most trafficking incidents are internal to South Asia. In 2015, the vast majority of trafficking cases that India's National Crime Records Bureau reported were internal to the country or coming into India through its land borders with Nepal and Bangladesh (National Crime Records Bureau 2015). One way the Indian government addresses this trafficking is through international engagement. Indian laws draw heavily on international definitions of trafficking - most often from the United Nations or the United States. The UNODC defines human trafficking as 'the acquisition of people by improper means such as force, fraud or deception, with the aim of exploiting them', and the Indian government mobilizes a similar definition of trafficking in the Criminal Law (Amendment) Act, 2013 (United Nations Convention against Transnational Organized Crime 2000). ${ }^{11}$ To police trafficking, India implements suggestions found in the United States' Trafficking in Persons Report. Central to the state's definition and policing of trafficking is the perception that young, poor women and children from minority communities are at the greatest risk for trafficking.

Trafficking permeates contemporary international politics, and UNODT argues that 'virtually all countries' are impacted. Despite the prevalence of this discourse, the numbers of confirmed cases of trafficked persons are relatively small. Further obscuring cases of trafficking are that when people identifying as survivors of trafficking come forward, their histories are questioned and their stories disputed.$^{12}$ Furthermore, initiatives to help trafficking victims are often underutilized. For example, in response

11 The Government of India defines trafficking in a similar way: 'Whoever, for the purpose of exploitation, (a) recruits, (b) transports, (c) harbours, (d) transfers, or (e) receives, a person or persons by using threats, or using force, or any other form of coercion, or by abduction, or by practicing fraud, or deception, or by abuse of power, or by inducement, including the giving or receiving of payments or benefits, in order to achieve the consent of any person having control over the person recruited, transported, harboured, transferred or received, commits the offence of trafficking' (Government of India 2013:5).

12 Perhaps the most recent major dispute of a trafficking survivor concerns Somamly Mam, a Cambodian anti-trafficking activist. In 2012 and 2013, news stories that disputed Mam's history were run first in Cambodia and then in the United States. As a result, she closed her foundation. 
to international pressure arguing the ubiquity of trafficked persons in the Arabic-speaking Gulf, safe houses were created in Dubai, UAE, as a place for trafficking victims to stay. These shelters, however, are usually empty. One shelter that could accommodate 150 people, for example, only housed a total of 21 victims in all of 2007 (United Arab Emirates National Committee to Combat Human Trafficking 2009: 17-19).

In discussions of trafficking, the horrific experiences of a few trafficked person are taken as signs of systemic and prevalent abuse. This is reinforced by trafficking's slippery numbers and contested stories. In practice, trafficked persons seem to be hard for law enforcement officials to find and trafficking cases are difficult to successfully prosecute. In India, for example, trafficking cases are prosecuted only 13 per cent of the time. Of the cases that are prosecuted, less than half of the people accused of trafficking are convicted of any crime. ${ }^{13}$ The difficulty in locating and identifying trafficked persons stands in stark contrast with the prevalence of trafficking in popular culture. Pardis Mahdavi has pointed out the conflation of sex work and exploitation often underlies scholarly approaches to women's sexual labour. In her work on Dubai, Mahdavi asks: 'How do global conversations about trafficking (and media and journalistic representations such as Taken or MTV's EXIT program) create an image of the experiences of migration, forced labour, and sex work in the minds of the public?' (2011: 11-13). She approaches this question by exploring how trafficking is rooted not only in international policy, but in activist discourses in North America and Europe. She finds that 'trafficking' means both 'too little and too much': the term collapses social, economic, and gendered differences (Mahdavi 2011: 11-13). As seen in the case of Indian emigrants to the Gulf, this discourse is also prevalent in social commentaries regarding female migration. Trafficking often appears vague and unspecific when viewed by law enforcement, but the discursive power of trafficking has a wide impact on emigration policies.

So how are we to understand this pervasive, yet hard to find problem? One approach taken by scholars is focusing on the role of policies originating in the United States and Western Europe to define and lend weight to the category of trafficking. For example, Simanti Dasgupta has examined how Indian policies are consciously constructed so that India avoids being downgraded in the United States' annual Trafficking in Persons Report. The result, Dasgupta argues, is that sex workers in Calcutta, India, are 'rendered inaudible' (2014). Both Dasgupta and Mahdavi find that narratives

13 Out of 17,599 cases of trafficking, only 2284 cases were brought to court in 2014. These court cases resulted in 1029 convictions (National Crime Records Bureau 2014:106). 
of trafficking arise in Western Europe and North America, and then these discourses and their accompanying policies shape practices in South Asia and the Middle East. A central aspect of these international approaches to trafficking is that some people are more vulnerable than others. Martha Fineman argues that vulnerability is 'inherent in the human condition,' and, by examining vulnerability in this way, she argues a more responsive state (2008: 1). Prabha Kotiswaran explains that Fineman's engagement with vulnerability means that scholars should not examine vulnerability through the lens of victimhood, but, rather, as a critique of liberalism. Through this critique, Kotiswaran finds trafficking is not exceptional to sex work, but rather a systemic problem of vulnerable labour (2012). Kotiswaran's approach highlights the power imbalances and ambiguities inherent in the discourse of trafficking.

In the case of Indian migration to the Gulf, the discursive strength of trafficking simultaneously builds upon and further entrenches the vulnerability of working-class women. The Indian government regulates emigration using the assumption that certain citizens face greater vulnerability when abroad, and the border is therefore a site where citizens who are considered vulnerable face greater scrutiny and restrictions. These restrictions arise out of an effort to stop trafficking at the border, but it is through this differentiated citizenry that trafficking produces power imbalances. Often, this approach to trafficking is viewed as an extension of Euro-American anti-trafficking policies and incentives. However, attempts to stop trafficking illuminate how present practices by the Indian government are informed not only by Euro-American policies, but are also shaped by the history of Indian emigration procedures. Both historically and in the contemporary moment, some citizens are conceived of as vulnerable. Bureaucrats argue the nation-state must protect its citizens, even if protecting them entails curtailing their rights. Examining this context reveals how Indian women, and particularly Indian Muslim women, are seen as being particularly susceptible to sexual predation. In this analysis, gender, class, and religion are all central elements in defining what restrictions a person faces while attempting to emigrate.

\section{Vulnerable Subjects and Dependent Citizens}

The assumption that some citizens are more vulnerable than others and require greater protection from the state can be traced back to British colonial laws overseeing emigration. The contemporary construction of 
Indian emigrants as vulnerable builds on the Emigration Act of 1922, which was written by the British colonial government after indentured labour became illegal. The Emigration Act of 1922 outlined three types of emigrants that were similar to those specified in the Emigration Act of 1908, but in 1922 the categories were defined more broadly. According to the Emigration Act of 1922, the first type of emigrant category was composed of unskilled workers or labourers, such as agriculturalists, porters, and rickshaw pullers. These workers were prohibited from migrating to any country that was not approved by Parliament. ${ }^{14}$ The second type of emigrant were categorized as skilled workers 'of a comparatively low order and status, belonging to classes of persons who by reason of their ignorance, were likely to be imposed upon or by reason of the number in which they emigrate were likely to create political or economic problems in the country of immigration'. This category included domestic servants, artisans, clerks, shop assistants, entertainers, and food servers (Ministry of External Affairs 1954a; see also the Indian Emigration Act of 1922, section 2). The third category of emigrant consisted of professionals, such as businessmen, doctors, lawyers, and students. These professionals were assumed to have a higher degree of intelligence or knowledge' and were thus left outside of the scope of the 1922 Act and not required to obtain 'No Objection Certificates' from the government (Ministry of External Affairs 1954a; Ministry of External Affairs 1953b; Ministry of External Affairs 1954b). Women and minors faced additional impediments to emigration. Classified together, they were prohibited from emigrating unless the Protector of Emigrants, upon 'examination' of the potential emigrant, was 'satisfied that he/she can take care of himself/ herself in the country of employment'. ${ }^{15}$ Using the discourse of protecting vulnerable groups, these laws reduced the ability of women, children, and unskilled workers to migrate.

The Emigration Act of 1922 is one historical tendril connecting colonial policies and the discursive construction of trafficking. It is clear that the protection of vulnerable populations was central to the Emigration Acts, but the history of trafficking is also intertwined with colonial expansion. The British Raj was interested in not only moving, but also regulating populations

14 Countries approved for migration by unskilled workers were printed in the Gazette Notification by the Central Government after receiving approval by Parliament (Ministry of External Affairs, 1954a; Ministry of External Affairs, 1953a).

15 Limitations on women's ability to emigrate relates to their precarious citizenship status. As discussed by Vazira Zamindar, the domicile requirement for citizenship established in 1949 formalized women's statuses as citizens who were dependent upon their father or husband (Zamindar 2007; Ministry of External Affairs 1953a). 
(Limoncelli 2010). Within the context of regulating prostitution in India, the kinds of work in which women could legally and productively participate were reduced. In legislation written by the British colonial government, such as the Contagious Diseases Act and the Emigration Act of 1922, women were conceptualized as a vulnerable and dependent population. Centrally, women were defined through their relationship to men; when women were not acting as wives or mothers, they were thought to be participating in the sex industry.

The role of women in nationalist and anti-colonial discourses has also influenced India's current attempts to stop human trafficking. For nationalist and anti-colonial thinkers, women - particularly middle-class Hindu women - became metonymically representative of the Indian nation (Sangari \& Vaid 1999 [1989]: 14). The association between womanhood and the nation coincided with the re-imagination of the public and private spheres in India and entailed a split between the material and spiritual worlds in which the material, outer world was the realm of the colonized and the spiritual, inner world was the realm of the home and of women. The result was that women became not only symbolic of India, but also of the country's morals. While Indian women were able to enter the workforce, they were expected to 'remain essentially unwesternized' and to participate in the reformation of 'vulgar working class women' (Chatterjee 1989). These projects to reform women were not only articulated by Hindu nationalists; Muslim women were also seen by the 'ulama ('Muslim scholars') and Muslim nationalist leaders as a population in need of education and refinement (Metcalf 2002; Minault 1982: 6o-61).

In these nationalist and anti-colonial discourses, women were key figures for defining the future nation, but their roles were confined to the home. Women were envisioned primarily as members of their families, and the definition of a woman was inherently tied to her role as mother and wife. Within this conception, the citizenship of women was dependent upon their husband, and the (re)production of future citizens was of more importance than a woman's own citizenship (Rajwade 1938: 83 ). ${ }^{16}$ Motherhood was women's primary role, and beginning in the late eighteenth century, and the idea of Bharat Mata ('Mother India'), became increasingly popular. As Bharat Mata grew in popularity, India became representable pictorially and verbally as a woman (Ramaswamy 2010: 9; Gupta 2002). Through this

16 The exclusion of women from political life was also lamented in Pakistan. For example, Kishwar Naheed's poetry critiques the social structures that do not encourage women to 'enter into the streets' (Naheed 1985). 
repeated association, women came to not only represent, but also embody, the Indian nation.

In postcolonial India, working class women's interactions with the state continued to be mediated by their relationships to men. As India and Pakistan made the transition from one to two states, the Indian government was challenged to define who was a citizen of India and who was a citizen of Pakistan. Even before the Indian constitution was passed on 26 January 1950, citizenship provisions were brought into force. As shown in Vazira Zamindar's work on Partition, these citizenship provisions linked 'birth, residence, migration, and citizenship'; a "domicile" and birth "in the territory of India"' were needed for a person to be a citizen of India. ${ }^{17}$ By following the legal doctrine of coverture and defining citizenship by domicile and birth, women's citizenship became contingent upon their husbands (Grapevine 2015). The close association between women, the home, and the nation meant that women needed to be located within a family if they were to make claims for rights. The nation took on a familial role as well, with the goal of protecting Indian women. The close association between women and the Indian nation also meant that trafficking and, particularly, sexual predation were affronts to the national honour and morality.

\section{Managing Emigration in the Postcolonial State}

These discursive constructions of women were reinforced by the policies enacted by the postcolonial state as bureaucrats in the Indian government debated and shaped emigration regulations and procedures. Beginning in the 1950s, the Indian government developed bureaucratic apparatuses to oversee the emigration of workers. In bureaucratic approaches to emigrants, two competing notions of Indian citizens were articulated. In one, citizens were vulnerable; in the other, citizens were rational liberal actors (Wright 2015: 61-102). Indian bureaucrats shaped emigration regulations and practices in the attempt to ensure both the rights of Indians to emigrate and the rights of Indian citizens abroad. Furthermore, as questions regarding the nature of the state and citizens were debated and implemented, bureaucratic practices developed a conceptualization of the Indian state and its citizens that is still at play in emigration policies today.

17 Zamindar points out that this is derived from colonial law, and that the domiciles of children under eighteen are dependent on their fathers and the domiciles of women are dependent on their husbands (2007). 
India's new status as an independent nation provided an important framework and context for this debate. One official wrote that the Indian government's view was that 'emigration from dependent British India was a source of embarrassment; emigration from free India may be a source of strength' (Ministry of External Affairs 1954b). To ensure that emigration was a source of strength, any proposal for Indian emigration had to be considered on its own merits and would only be permitted if emigration was sure to be on 'honourable terms, consistent with the dignity of India' (Ministry of External Affairs 1954b). In such arguments, the honour of India was embodied in each migrant and it was the Indian government's duty to oversee emigration and thereby maintain India's reputation abroad. Also, in the 1950s, many members of the government considered migration to have been a problem in the past, but no longer a pressing concern. In postcolonial India, they argued, emigration affected only a 'fringe' of the Indian population (Ministry of External Affairs 1954b). Emigration was also understood to be a permanent activity, whereby Indians settled abroad for the entirety of their lives. Conflating emigrants with indentured labourers, many government bureaucrats characterized Indians abroad as having moved out of India between the 1850s and 1920s (Ministry of External Affairs 1954b). ${ }^{18}$

Emigration laws, assumptions about the permanence of emigration, and histories of coverture meant that Indian women were not envisioned as potential emigrants by the early Indian state. When women did emigrate, the assumptions were - and continue to be today - that they were either moving with their husbands or participating in 'immoral activity'. This was particularly exemplified in a series of complaints brought to the Indian government regarding the 'immoral traffic in women' in the 1950 s and $1960 s$. In 1950, the Indian government ratified the International Convention for the Suppression of the Traffic of Persons and of the Exploitation of the Prostitution of Others. In 1956, the government passed the Suppression of Immoral Traffic in Women and Girls Act, which lays out the legal penalties for the trafficking women and girls. While this Act was a fulfilment of the Indian government's commitment to the $195^{\circ}$ United Nations convention, the way in which the Act was and continues to be mobilized reveals Indian genealogies of trafficking.

Most tellingly, in the 1950s and 196os, were the complaints received by the Indian government from Indian citizens regarding the marriage of

18 For a more detailed discussion of indentured labour, see, for example: Carter 1995; Bates 2000; Yang 1989. 
Indian Muslim women to Muslims from the Persian Gulf. Allegations were made that Gulf Arabs married these women, but then, once in the Gulf, their husbands threw off their marital ties and would 'sell them' sexually (Ministry of External Affairs 1961; Ministry of External Affairs 1963). These cases of 'immoral trafficking' were difficult to track because Indian women travelled on their husbands' passports after marriage (Sethi 1963; Embassy of India, Kuwait 1964). The result was that Indian bureaucrats were left responding to the individual petitions of concerned Indian citizens.

One case of the immoral traffic in women was brought to the attention of the postcolonial Indian state through letters written from Rubiyabai, a Muslim woman from Bombay. In her letters, Rubiyabai was concerned because her daughter, Zuleka, had married a man she identified as 'Arab' and she was afraid that Zuleka had been forced into prostitution in Bahrain. Rubiyabai was illiterate, but she dictated letters to the Indian Government asking for help. One of these letters reads:

I have heard from people who are coming from Bahrain, that my daughter is kept in a sort of Jail under lock and key, and that the said Saba Bin Rashid [Zuleka's husband] desires to make my daughter into a prostitute, and as such I am deeply grieved by this, and request you to be kind enough to make some special speedy enquiry into this matter and redress my grievances and save my daughter from the HELL that she is being put to, for which act of kindness I shall be much obliged, and it would be far better on my part if you could kindly arrange to send my said daughter back to India. (Rubiyabai 1961)

In response to this letter, the Indian Government asked the British Agent in Bahrain to look into the situation. In this and in the other cases I found in the archives, neither the allegation of forced prostitution nor the allegation of a wife's ill treatment by her 'Arab' husband was substantiated. However, fears of the ill treatment of women and neglect of the marriage contract continued.

Rubiyabai's fears were spurred by community gossip that circulated from the Gulf to India. Friends of friends with connections in the Persian Gulf told Rubiyabai that Zuleka was trapped within her home and Zuleka's new husband was not honouring the marriage. They reported that the husband had misused Zuleka and forced her into prostitution. One reason Rubiyabai believed Zuleka was not free in Bahrain was because Zuleka began practicing purdah (physical segregation from men). The British political agent that visited the home found no problems with this arrangement and he also found 
that Zuleka had embraced the practice of purdah (Rubiyabai 1961). Despite the conjectural nature of these claims of the 'immoral traffic of women', in 1965 the Ministry of External Affairs still found - citing this case and similar ones - that 'Arab nationals from the Persian Gulf area are connected with immoral traffic in Indian women' (Office of the High Commissioner of the United Kingdom 1961). This 'immoral traffic' was the given reason for a series of passport requirements instituted in 1965 in collaboration with British Agents in the Gulf with the intention of regulating women's travel to the Arabic-speaking Persian Gulf (Ministry of External Affairs 1965).

In the contemporary moment, women's dependency on male relationships for migration is most clearly seen in the process women who are over 3o-years-of-age must go through to migrate - particularly the 'No Objection Certificate' that must be signed by a husband or father, and the need for those wishing to hire maids to be 'vouched for' by an Indian national (Consul General of India, Dubai 2016). This rule is meant to protect women and the reputation of Indians abroad. For men and women who are considered vulnerable to migrate legally, they must first receive permission from the Indian government via a local Protector of Emigrants (POE) office. At the POE offices, the officials are required to check the documents of migrants who have 'Emigration Check Required' stamped in their passports. The POE officers ensure that the worker has a valid job offer with a company that is not blacklisted by the government. The stated purpose behind this form of checking is to reduce the exploitation of vulnerable Indians. When unskilled or semi-skilled workers migrate legally, it is the job of the recruiting agent to ensure that the government guidelines are followed and that the jobs they are going to meet the government's standards. In the process of migration, women become imbricated in familial and paternal relationships that are mirrored by the Government of India.

\section{Conclusion: The Contemporary Moment and Women's Migration}

The current policies regarding women migrating to the Gulf and the Indian government's interest in the moral position or virtue of women in the Gulf are not new. Connecting concerns, shared by such people as Rubiyabai, concerning 'immoral traffic' and the contemporary moment are the fears for women's virtue, the assumed obligation of the Indian government to protect that virtue, and the subtle backdrop of class as an analytic space in which these gendered anxieties about virtue play out. Poor women have unequal access to migration and employment abroad, and this reinforces 
the inequalities they face in India due to their gender and their economic position. This inequality is a marked contrast to the relative freedom that upper-class women have in moving abroad. For example, upper-class young women, such as daughters of recruiting agents, frequently go abroad to England or the United States to study. Recruiting agents would tell me proudly about how their daughters studied at American universities, and no one ever suggested that this was an immoral activity.

Trafficking discourses do not impact all Indian women equally. Some Indian Muslim women wished they could travel to the Gulf to mitigate the economic and social inequalities they experienced in India. ${ }^{19}$ One woman I met in the Gulf, Fahmida, told me that she loved living in the United Arab Emirates because she felt she was allowed to openly practice her Islamic faith. In particular, Fahmida said in the Gulf she could wear hijab ('head covering'), without fear of harassment. The harassment she experienced in India, Fahmida told me, meant that she understood herself to be wrapping not only her headscarf, but also her jur'at ('boldness') whenever she left her home. She felt that this boldness was required so that she would not be intimidated by people's negative comments when she walked down the road in India. For Fahmida, living in the Gulf allowed her to express her faith as she chose and avoid some of the stigma she experienced in India because she was a Muslim.

While upper-class women may travel with more ease, the barriers that poor women face when trying to travel internationally cannot be explained by simply a lack of certain skills or capital. The restrictions put on travel by the Indian government in an effort to protect the most vulnerable citizens create obstacles to emigration. As news articles highlight the potential for women to experience trafficking, less opportunities for Indian Muslim women arise. The conflation of India with Indian women permeates the contemporary moment and informs the restrictions on women travelling internationally. India's reputation is located in the body of women abroad, and poorer women are constructed as unable to protect themselves. The effect is that working-class and most middle-class women are unable to enter the oil economy. Instead, women must rely on their fathers or brothers not only for legal status, but also financial support. Furthermore, the current implementation of trafficking policies calls into question how much the policies actually work to protect women. As emigration is currently regulated,

19 This reason for emigration was shared by Indian Muslim men as well; social and economic discrimination are two of the reasons Indian Muslim men emigrate to the Gulf in disproportionately large numbers. 
young women who have not matriculated are unable to travel legally for work. This elides the ability of these women to migrate in order to inform their marriage decisions or access the larger salaries that are available in the Gulf. It also means these women may only work abroad illegally. Women are put in positions where they may be imprisoned by Gulf governments and are made vulnerable to violations of their labour rights, as they have no legal status in their host country. The invisibility of women to recruiting agencies means that the process through which women migrate creates the very problem that trafficking policies and procedures attempt to address.

\section{References}

Amnesty International (2014). 'My Sleep is My Break': Exploitation of Migrant Domestic Workers in Qatar. London: Amnesty International, International Secretariat. Banerjee, C. (2010). The clay pigeons. Outlook India, September 21, pp. 1-4.

Bates, C. (2000). Coerced and migrant labourers in India. Edinburgh Papers in South Asian Studies, 13, pp. 2-33.

Carter, M. (1995). Servants, Sirdars, and Settlers: Indians in Mauritius, 1834-1874. Oxford: Oxford University Press.

Chatterjee, P. (1989). The nationalist resolution of the women's question. In: K. Sangari and S. Vaid, eds., Recasting women:Essays in colonial history. New Delhi: Kali for Women, pp. 233-253.

Consul General of India, Dubai (2016). Recruitment of housemaids. [online] Available at: http://www.cgidubai.org/housemaid/

Dasgupta, S. (2014). Sovereign silence: Immoral traffic (prevention) act and legalizing sex work in Sonagachi. PoLAR: Political and Legal Anthropology, 37, pp. 109-125.

DNA Investigations Bureau (2011). Bar Girls: Banned in Mumbai, Trafficked to Dubai. Daily News \& Analysis, [online] pp. 1-6. Available at: http://www.dnaindia. com/mumbai/report-bar-girls-banned-in-mumbai-trafficked-to-dubai-1594036 [Accessed 20/12/16]

Embassy of India, Kuwait (1964). Embassy of India, Kuwait to the Ministry of External Affairs. [letter] National Archive of India, Ministry of External Affairs, New Delhi, India.

Fineman, M. (2008). The vulnerable subject: Anchoring equality in the human condition. Yale Journal of Law and Feminism, 20, pp. 1-23.

Gardner, A. (2010). City of Strangers: Gulf Migration and the Indian Community in Bahrain. Ithaca: Cornell University Press.

Government of India (1956). The Immoral Trafficking Prevention Act, 1956. National Archives of India, New Delhi, India. 
Government of India (1983). The Emigration Act, 1983. New Delhi: Government of India.

Government of India (2013). The Criminal Law (Amendment) Act, 2013. New Delhi: The Gazette of India.

Grapevine, R. (2015). Family Matters: Citizenship and Marriage in India, 1939-72. PhD Thesis. University of Michigan.

Gupta, G. (2002). Sexuality, Obscenity, Community: Women, Muslims, and the Hindu Public in Colonial India. New York: Palgrave.

Kotiswaran, P. (2012). Vulnerability in domestic discourses on trafficking: Lessons from the Indian experience. Feminist Legal Studies, 2o(3), pp. 245-262.

Lall, R. (2009). In Dubai, thriving Indian clubs with a dark side? The Times of India, November 23.

Limbert, M. (2014). Caste, Ethnicity, and the Politics of Arabness in Southern Arabia. Comparative Studies of South Asia, Africa and the Middle East, 34(3), pp. 590-598.

Limoncelli, S. (2010). The Politics of Trafficking: The First International Movement to Combat the Sexual Exploitation of Women. Palo Alto: Stanford University Press.

Mahdavi, P. (2011). Gridlock: Labor, Migration, and Human Trafficking in Dubai. Palo Alto: Stanford University Press.

Metcalf, B. (2002). Islamic Revival in British India:Deoband, 1860-19oo, 2nd ed. New Delhi: Oxford University Press.

Meyers, D. (2011). Two victim paradigms and the problem of 'impure' victims. Humanity: An International Journal of Human Rights, Humanitarianism, and Development, 2(2), pp. 255-275.

Minault, G. (1982). The Khalifat Movement: Religion and Political Mobilization in India. New York: Columbia University Press.

Ministry of External Affairs (1953a). Report on the working of the Indian Emigration Act (No. VII of 1922) for the Year 1952. [report] National Archives of India, New Delhi, India.

Ministry of External Affairs (1953b). Annual report on the working of the Indian Emigration Act VII of 1922 and the rules framed thereunder for the port of Calcutta for the year 1952. [report] National Archives of India, New Delhi, India.

Ministry of External Affairs (1954a). Indian Emigration Act 1922 - Considerations of to extend its provisions to journeys by AIR and LAND - unaccompanied domestic servants, etc. [file] National Archives of India, New Delhi, India.

Ministry of External Affairs (1954b). Material required by Sri Lanka Sundaram M.P. for a paper on the 'Effect of Emigration'. [file] National Archives of India, New Delhi, India.

Ministry of External Affairs (1963). Letter from the Ministry of External Affairs to the Indian Embassy Cairo. [letter] National Archives of India, New Delhi, India.

Ministry of External Affairs (1965). Letter from the Ministry of External Affairs to the Indian Embassy Baghdad. [letter] National Archives of India, New Delhi, India. 
Ministry of Overseas Indian Affairs (2013). Annual Report 2012-13. New Delhi: Government of India.

Naheed, K. (1985). Aurat: Khaab aur Khaak kai dar-mayaan. Lahore: Guul-Rang Publishers.

National Crime Records Bureau (2014). Crime in India-2014. New Delhi: Government of India.

National Crime Records Bureau (2015). Crime in India-2015. New Delhi: Government of India.

Office of the High Commissioner for the United Kingdom (1961). Letter No. Gen. CT/28 dated o6 March, 1961 from the Office of the High Commissioner for the United Kingdom, New Delhi, to the Ministry of External Affairs, New Delhi. [letter] National Archives of India, New Delhi, India.

Patel, R. (2010). Working the Night Shift. Stanford: Stanford University Press.

Rajan, S., Irudaya, V., Varghese, J., and Jayakumarm, M. (2010). Looking beyond the Emigration Act 1983: Revisiting the recruitment practices in India. In: S. I. Rajan, ed., Governance and Labour Migration: Indian Migration Report 2010. New Delhi: Routledge India, pp. 251-87.

Rajwade, L. (1938). The Indian mother and her problems. In: S.K. Nehru, ed., Our cause: A Symposium by Indian Women. Allahabad: Kitabistan, pp. 73-89.

Ramaswamy, S. (2010). The Goddess and the Nation: Mapping Mother India. Durham: Duke University Press.

Rubiyabai (1961). Letters from Rubiyabai to Ministry of External Affairs and Counsel for India at Bahrain. Government of India, Ministry of External Affairs, New Delhi, India.

Sangari, K. and Vaid, S. (1999 [1989]). Recasting women: An introduction. In: K. Sangari and S. Vaid, eds., Recasting women: Essays in colonial history. New Delhi: Kali for Women, pp. 1-26.

Sethi, C.L. (1963). Letter from C.L. Sethi to Shri A. Dayal. [letter] National Archives of India. Ministry of External Affairs, New Delhi, India.

Shah, N. (2000). Relative Success of Male Workers in the Host Country, Kuwait: Does the Channel of Migration Matter? International Migration Review 34(1), pp. 59-78.

Stirr, A. (2017). Popular music among Nepalis in Bahrain: Nightclubs, media, performance, and publics. In Global Nepalis: Religion, Culture, and Community in a New and Old Diaspora. Oxford: Oxford University Press.

United Arab Emirates National Committee to Combat Human Trafficking (2009). Combatting Human Trafficking in the UAE: Annual Report, 20o8-20og. [report] Available at: http://www.nccht.gov.ae

United Nations, General Assembly (2000). United Nations convention against transnational organized crime. [resolution] A/55/383. 
US Department of State (2015). Trafficking in persons report 2015. [report] Available at: www.state.gov/j/tip.

Vora, N. and Koch, N. (2015). Everyday Inclusions: Rethinking Ethnocracy, Kafala, and Belonging in the Arabian Peninsula. Studies in Ethnicity and Nationalism, 15(3), pp. 540-552.

Wright, A. (2015). Migratory Pipelines: Labor and Oil in the Arabian Sea. Doctoral Dissertation, University of Michigan.

Yang, A. (1989). The Limited Raj: Agrarian Roots in Colonial India, Saran District, 1793-1920. Berkeley: University of California Press.

Zachariah, K., Prakash, B., and Rajan, S. (2004). Indian workers in the UAE: Employment, wages, and working conditions. Economic and Political Weekly, 39(22), pp. 2227-2234.

Zamindar, V. (2007). The Long Partition and the Making of Modern South Asia: Refugees, Boundaries, Histories. New York: Columbia University Press.

\section{About the Author}

Andrea Wright is an Assistant Professor in the Department of Anthropology and the Program in Asian and Middle Eastern Studies at the College of William and Mary. Her current book project looks at the development of the oil industry in the Arabian Sea and the role Indian migrant labourers have played in shaping that industry. 



\title{
$7 \quad$ The Journey to Europe
}

\author{
A Young Afghan's Experience on the Migrant Route \\ James Weir and Rohullah Amin
}

Jones, Reece and Ferdoush, Md. Azmeary (eds), Borders and Mobility in South Asia and Beyond. Amsterdam: Amsterdam University Press, 2018 DOI: $10.5117 / 9789462984547 / \mathrm{CHO} 7$

\begin{abstract}
This chapter tells the story of Akbar, a young Afghan man who left Kabul during the summer of 2015 to escape war and poverty. Three months later, after a torturous journey that included abuse by both smugglers and the authorities, Akbar arrived in Frankfurt, emotionally, physically, and financially broken. The authors frame a harrowing, first-person account of Akbar's journey across Western Asia and Central Europe: first, recounting his parents' refugee experiences during the Soviet-Afghan War; later, describing the circumstances that convinced his family to support Akbar's journey; and finally, explaining his family's thoughts about Akbar's future in Germany. The chapter concludes with speculations about the potential political ramifications of the forced repatriation of (perhaps) tens of thousands of Afghans from Europe. This story of one young man and his family's history helps to humanize the confusing and often impersonal accounts of the global migration crisis and provides necessary historical context for grasping the contemporary Afghan refugee crisis.
\end{abstract}

Keywords: refugee, Afghanistan, migration crises, human smuggler, Germany, oral history

At 11 PM on a hot summer night in the first week of June 2015, after weeks of delay, the call finally came. 'The game is on', the smuggler announced. Akbar was told he had an hour to get across town to the Kabul central bus station. ${ }^{1}$ With US $\$ 250$ hidden in the folds of his shalwar kameez and a knapsack containing two pairs of clothes, a sewing needle his mother had 
taught him to use in preparation for the journey, dried fruit, hard-boiled eggs, naan, and an old Samsung phone, Akbar set off to begin a new life anywhere far from Afghanistan.

Akbar rushed emotional goodbyes with his mom and two sisters. Then Omar, Akbar's older brother, accompanied him to the bus station. Akbar's father and eldest brother were at work, unable to say goodbye in person. The two brothers sat at the bus station into the early morning, waiting until it was time for Akbar to board. Akbar was to meet his smuggler in Nimroz, a remote desert province on the Iran-Pakistan border, a lawless region notorious for smuggling and banditry. Fearful, Omar recounted his brother's departure:

I hugged Akbar a few times, and I told him not to forget us. It is painful to watch your younger brother leave. I cried 100 per cent. He sat in the bus. I said goodbye two or three times, while the bus prepared to leave. This moment was very painful. If he goes to Turkey, and then somewhere else, when his life becomes better, he might forget us. My mom kept calling. We were afraid he would die, or be put in prison. He'd be lonely. He was very young, and never travelled. We did not believe he would arrive.

A few weeks before, Akbar and his father had met Aziz in Paghman to discuss the trip. Aziz's family is well known locally for smuggling people to Turkey and Europe. US $\$ 1500$ was deposited as collateral for the transit to Turkey. Aziz directed Akbar's father to give that money to a third party, an agent on the second floor of a small money exchange shop in a bustling Kabul market. When the agent received a call from Akbar announcing that he had safely arrived in Turkey, the money would be released to Aziz's associates in Kabul - at least, that was the pre-departure agreement.

This chapter recounts Akbar's often-horrifying experiences crossing West Asia and Eastern Europe in the summer of 2015. After a 3-month ordeal he arrived in Germany where he sought asylum, and from where, at the time of this writing, he faces the growing likelihood of forced deportation (Strickland 2016). But our account here begins with Akbar's parents, who were displaced in the early years of the 'Afghan refugee crisis' in the late 1970s, when the Cold War first erupted on Afghan soil. At that time, Akbar's (as yet unacquainted) parents were amongst the two to four million Afghans forced to seek refuge in Pakistan and Iran.

Across four decades, Afghan refugees have had to contend with harrowing journeys, uncertain receptions in host countries, family debt and destitution, and helpless dependence upon reluctant others after arriving 
at their destinations. The geopolitical circumstances of the Afghan conflict have evolved, but the contours of the refugee experience remain mostly consistent. Akbar is one of millions who found waiting for the end of conflict at home intolerable in 2015, who took to their feet seeking a better life across international borders, who were imprisoned and abused en route, and who escaped complex conflicts at home for precarious receptions in host countries (BBC 2017). Meanwhile, in Europe, the migration crisis vexes political relations between the states of the European Union and their bordering countries, as Marta Zorko describes in the next chapter of this volume.

This chapter draws upon face-to-face interviews conducted with Akbar's entire family in December 2015, a series of Skype interviews with Akbar (speaking from a German refugee hostel) in early 2016, and life history interviews conducted with Akbar's parents during the summer of 2005. We narrate some of the difficulties and costs of the journey, and describe the tedious circumstances encountered in the German refugee hostel where Akbar currently resides. ${ }^{2}$ Readers will find that the narrative changes into the first person when describing Akbar's experiences between Kabul to near Frankfurt. The earlier and later sections, which are based upon extensive interviews with family members, are conventionally told from the authors' perspective. But Akbar's journey is written in the first-person, and draws solely on his account of his experiences in transit. In the conclusion, we consider the implications of the present influx of refugees for Europe and the potential for the forced deportation of Afghans to further destabilize the already fractured social and political environment in Afghanistan.

\section{Third-generation Migrant: Akbar's Family History}

The authors' relationship with Akbar and his family began in 2004, when he was nine-years-old. His parents were the live-in caretakers at an American NGO in Kabul where James was based while he conducted fieldwork for a dissertation in cultural anthropology, and where Rohullah was employed after years as a refugee himself in Iran. Many afternoons, the authors joined

2 In 2005 James Weir conducted life history interviews with Akbar's parents, which is the primary source for the biographical information in the family history section. The later sections draws upon family interviews conducted in Kabul in late 2015. The first person account that follows is an edited version of the journey told from Akbar's perspective, based upon Skype interviews conducted in early 2016, while Akbar was in a German refugee hostel. This account has been reviewed with Akbar. 
Akbar and the other neighbourhood kids in football matches organized inside the grounds of the compound. Akbar was the youngest boy, and I (James) was the most senior player, so we were often paired when playing on our tiny pitch. My memory of Akbar is as a quiet, respectful boy, sometimes brooding, and often looking bewildered by the extravagant lives of the foreigners that passed through the compound. In a photo of Akbar from 2004, the boy stands awkwardly before a large spread of hors devours while inebriated Afghan and foreign men and women dance to a live Quawalli band.

In November 2015, I returned to the NGO-cum-guesthouse. Akbar's father, Ghahreman (a nickname meaning 'champion'), greeted me at the fortified steel gate. After friendly inquiries, grinning while serving pastries and green tea, he asked if I wanted to arm wrestle. A decade older and half a foot shorter than me, and after a life immeasurably harder than my own, he remains fit and playful. He won handily. He then told me that Akbar, his youngest boy, had walked to Frankfurt.

As I settled into a two-month stay in Kabul, Rohullah and I began informally asking Akbar's family about the young man's experiences and circumstances. The troubling story that emerged often contradicted our expectations. The expenses, in the end nearly US\$7000, and the abuses Akbar incurred en route, culminating with a beating by the Bulgarian police - which broke both Akbar's hand and his trust in European authorities - were worse than we had imagined. Long acquainted with the family and with our interest and concern now piqued, we asked if we could conduct formal interviews. Our goal was to document the family's role in the decision and preparations, Akbar's experiences in transit, and his circumstances in Germany. The family graciously agreed to let us interview them. We decided it was best to keep the identity of the family anonymous, despite the family all saying that it was unnecessary.

Akbar, like a few million Afghan millennials, is a third-generation refugee. He is the middle child of five siblings, all of whom were born as refugees outside of Afghanistan: his two older brothers were born in Pakistan; Akbar and his two younger sisters, in Iran. His parents escaped the Soviet-Afghan War in the early 1980 s as young adults with their separate families. They met and married while in exile in Pakistan.

Akbar's father Ghahreman is from Ghazni: a town that was once a thriving Buddhist centre in the seventh century and, a millennia ago, the centre of the Ghaznavid Empire, which stretched from North India across Afghanistan to include most of present-day Iran and swathes of Central Asia (Patan 2007). As of late 2016, this multi-ethnic city of 150,000 residents, a dangerous threehour drive south of Kabul, was contested by insurgents. Both the Taliban 
and the Islamic State (IS) target the large local Shia population (who are ethnic Hazaras) in an effort, common in many Middle Eastern countries, to provoke civil conflict by fomenting sectarian divisions (Al Jazeera 2015).

Ghahreman was a young man in 1978. He would have been around Akbar's age when the Soviet military entered Afghanistan to support its beleaguered Communist central government. Ghahreman recounted this period to us as: 'the mullahs said that the Russians were our enemies, and we must rise against them'. He emphasized the threats his family received if he and his brothers did not join the resistance: 'the Mujahedeen would have killed us; we had to join them'. Like a tsunami originating from the two great adversaries of the Cold War, money and weaponry washed across the impoverished country, breaking the social and political order in its path. Ghahreman and his companions fought an insurgency against Soviet and Afghan government forces, armed with US and Saudi resources that were distributed by Pakistan. Ghareman's insurgent group 'went to the hills', hiding in the mountainous countryside and often forced to survive without basic supplies (Linschoten and Kuehn 2012: 56).

As an untrained foot soldier on the frontlines of a popular yet disorganized and deadly war, Ghareman grew disillusioned as he watched what had been at first deemed an honourable 'jihad' in defence of Islam and Afghanistan descend into corruption, local rivalries, and rampant lawlessness. The value of his sacrifice then is unclear today. He complains: 'We stayed in the mountains, hungry and thirsty, feet bleeding, sleeping on the rocks and in caves. Sometimes the villagers fed us, and our leaders conducting the war grew fat and wealthy sitting comfortably out of harm's way in Pakistan and the Gulf States'. Like many former Mujahedeen foot soldiers, he is careful to distance himself from the notorious abuses perpetrated by most of the Mujahedeen leadership (Barfield 2010: 251-52).

After four years, he escaped Afghanistan to become a refugee in Pakistan, and later Iran. 'When I got married to Jamila, we had nothing. I was penniless.' This was an economic reality that tarred his image as a man in a male-dominated society. 'We stayed at my in-laws", he continued. 'Without work, I was ashamed to go home. I borrowed money and we went to Iran.' And that is where they remained, living in poverty, until 2002.

The corruption, cronyism, and lawlessness that took root in the early days of the 'jihad' worsened as the Mujahedeen parties took up arms against each other (Barfield 2010: 255). After the Soviet military retreated in 1989, a vicious civil war ensued - and eventually resulted in the emergence of the Taliban. The experience of watching the Afghan resistance to the Soviets become corrupt and then turn against each other has left many Afghans 
distrustful of national politics, and most leaders in general. This distrust in and frustration with national and international political processes has only been compounded over the past fifteen years, as extraordinary international expenditures of blood and treasure have had minimal influence on the security and economic welfare of ordinary Afghans. Instead, civilians continue to be caught between a deadly array of anti-government and government actors pursuing a confusing mix of political aspirations and material enrichment (Weir and Azamy 2015). Ten years before Akbar's departure, Ghahreman concluded his life history interview by saying, 'I hope my children can get educated, become good men, and be able to feed their mother when I am not alive'. Ten years later, his son Akbar, now a refugee in Germany, echoed his father's aspirations regarding his future in Europe, stressing the need to take care of an ailing family and his interest in obtaining a good education.

Akbar's mother Jamila is from a rural village in Paghman, a mountainous farming area on the outskirts of Kabul. She began her life story tersely, "There are so many problems in life. Where should one begin?' paused, and then continued, 'When I was about seven or eight my father died, a car ran him over, and we were alone'. As a fatherless girl, her life shaped by violence and poverty started when Soviet soldiers entered her village months later.

When the war began, her family risked their lives to support the resistance fighters. Her eldest brother left home to join the Mujahedeen. Young Jamila secretly took food to their hideouts in the mountains. Islam demanded that she support the fight against the communists; she explained, 'Cooking for the Mujahedeen meant rewards in the afterlife' - although she also said that she was never sure what the Russians wanted in Afghanistan.

But with young Jamila and her sisters maturing, war and lawlessness made their family of women increasingly unsafe: they became more and more vulnerable to abuse from the men in the Mujahedeen resistance, the Afghan government, and the Soviet forces. Three years into the war, Jamila's mom decided they had to leave; after months of thwarted efforts, the family succeeded in crossing the border on foot into Pakistan. Soon afterwards, Jamila was introduced to Ghahreman, who was fourteen years her senior, through an arranged marriage. Three years later, Ghahreman asserted his role as the head of the family to move the family of four from Pakistan to Iran against Jamila's wishes in search of work as a labourer. The journey involved long walks, with two infants in tow, across deserts and dangerous border crossings - a route that young Akbar would retrace three decades later when he began his journey to Europe. The family returned to Kabul shortly after the Taliban were forced from power in 2002. 
Many factors combine to make Afghans fearful about the future. Despite four decades of nearly continuous conflict, there is no indication of a political or peaceful resolution in the foreseeable future. At the time of this writing, the top US general in Afghanistan had recently warned the US Congress that billions of US dollars and thousands of soldiers were needed to break the stalemate in the country (Ewing 2017). After the initial high hopes of the early years of the 2001 US intervention in the country, the US and NATO withdrew the bulk of their forces in 2014 without defeating the Taliban. As a result, the economy tanked, unemployment surged, and an emboldened Taliban increased its attacks and territorial reach (Sidahmed and Akerman 2016).

Meanwhile, the 2014 Afghan presidential election was marred by widespread fraud, leaving an ineffectual and distrusted 'National Unity Government' that was divided between oppositional leaders (Gall 2014). The success of the military operation (Zarb-e-Azb ${ }^{3}$ ) in the Federally Administered Tribal Areas of Pakistan forced militants across the border into Afghanistan (Zahid 2015). Current estimates list at least twelve and as many as twenty insurgent groups operating on Afghan soil (S. Jones 2016). The most recent, the Islamic State (IS), commenced indiscriminate bombings and kidnappings in 2015, forcing ordinary Afghans to anticipate futures even more dreaded than the return of the Taliban. At the level of individuals, the emergence of IS further radicalizes some Afghans and attracts the desperately poor. IS' global aspirations and successes in Iraq and Syria promise people agency and reward in places where little of either exist (Azamy and Weir 2015).

Beyond security concerns, inadequate infrastructure and a surging population challenge life in Kabul. The capital city, designed nearly five decades ago for 700,00o residents, is the fifth fastest growing city in the world, with an estimated six million people (Rasmussen 2014). Garish indicators of international influences on the cityscape are the enormous fortified compounds containing mansions of the corrupt elite, who are among the few evident beneficiaries of the mismanaged international largesse. Akbar's sisters explained that simply walking to school is dangerous: to move through the city, they must find groups of people they trust. Military convoys frequently block traffic for hours at a time, creating insecurity for bystanders because insurgents frequently target those same convoys. Like their mother, these girls have matured amidst lawlessness and conflict, with the threat of abuse challenging their freedom of movement and the family's honour.

3 This is the Urdu name of the operation, which means a sharpening and cutting strike, and also it refers to the sword of the prophet Mohammad. 
Life without the promise of an adequate education, without basic health care for an ailing mother, and absent the rule of law on Kabul's streets or in government transactions, all contribute to Akbar's family's desire for a future anywhere else. Thus, when both the 'word on the street' and the international media confirmed that tens of thousands of Afghans were successfully entering Europe, Akbar saw an opportunity. In 2015, nearly 20 per cent (180,000) of the asylum seekers in the European Union originated in Afghanistan (BBC 2017).

But despite the multiple political factors that conspired to propel Akbar from Kabul, national conflicts and international failures were only the backdrop for an even more troubling reality: a problem with two conservative uncles, which became the decisive factor in the family's decision. After the Taliban fell from power in 2001, Akbar's family returned to Kabul, finding work and shelter at the American NGO. The authors first met the family there and Ghahreman remains employed at the NGO today. The entire family had lived in the institute's compound, where Akbar's mother made a living cooking and cleaning, until growing pressure from two uncles had forced her to leave the job. These two fundamentalist uncles have threatened the family for years, calling them kafirs ('infidels'), 'slaves of Americans', and, worse, accusing Jamila of being a 'prostitute' simply because she worked with Americans.

As Akbar grew into manhood, these confrontations grew more heated. After one particularly intense altercation between Akbar and these two uncles who were former Mujahedeen (and locally regarded as drug addicts with Taliban mentalities) nearly turned violent, the family determined that it was time to support Akbar's asylum efforts. Jamila explains, 'the Taliban is threatening because we work for Americans, the boys can be killed if they join government, but these two uncles are even more dangerous'. This factor, likely the most urgent amongst many, convinced the family to support and finance the young man's decision to leave home. Jamila explains: 'In the weeks leading up to his decision to go, Akbar had become quite difficult. He was fighting with his family, especially with his older brother, Masood. He would shout and say how dissatisfied he was with life here. So, when he decided to go after about a week, we decided to support him.'

Akbar's father, Ghahreman, remains a live-in employee at the American NGO, despite his family having to move away. He earns US\$250 a month working as a guard by night and caretaker by day. Between the amount required for the smuggler's fee and the travel expenses, the family committed US $\$ 1,75^{\circ}$ - seven months of Ghahreman's income - for Akbar's journey, believing that this enormous investment would be enough to get Akbar to Europe. Ultimately, the trip would cost the family nearly US $\$ 7000$, creating a debt that is likely impossible for them to repay. 
Figure 7.1 Typical Afghan Transportation

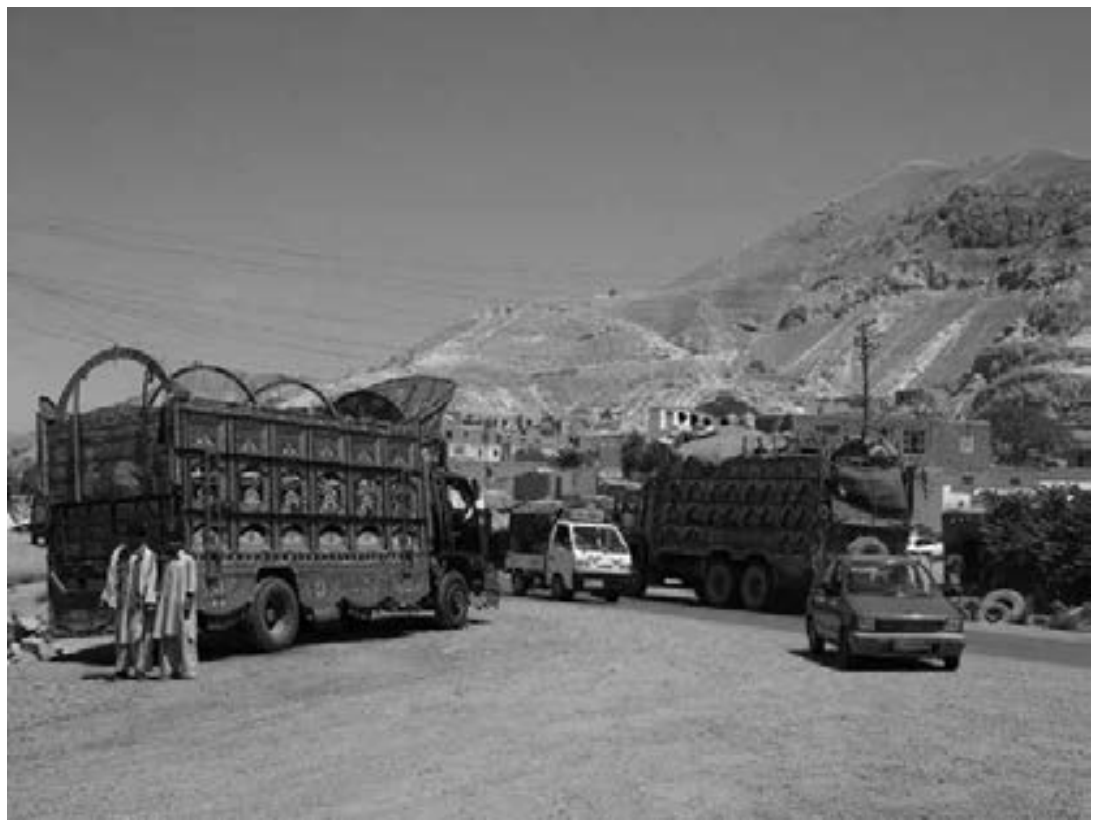

\section{The Journey}

Akbar was eight when he first set foot on Afghan soil. Twelve years later, with the bulk of US and NATO forces recently withdrawn and the Taliban and Islamic State expanding, Akbar became a refugee again, this time crossing his birthplace of Iran for prospects in Europe. In this section, we shift from Akbar's family history and pre-departure circumstances to narrate his journey from Kabul to his current residence in a German youth hostel. Separated from his family for the first time, having made his way across Western Asia and Eastern and Central Europe, we recount his journey below in the first person: a chronological account of his experiences as gathered through multiple Skype interviews.

\section{Kabul to the Iranian Border}

I thought travel across southern Afghanistan would be the most dangerous, but I was wrong. The Taliban stopped and searched our bus multiple times along the way from Kabul to Nimroz. In Nimroz I had to find Aziz, the smuggler, who arranged things. On the first day, I met Ali, from Baghlan. He is a little younger than me. He was scared. We talked and began travelling together. 
We took care of each other all the way to the Bulgarian border. He is in Austria now, and we still stay in touch.

Aziz (the smuggler) explained the route, put one guy in charge of us, and then left. After that, he coordinated everything by phone, and we never saw him again. That first night we were walking in a dangerous desert towards Iran. It was so hot. I called my brother Omar and told the family to pray for me. The Iranian border police shoot people.

Suddenly, Toyota pickup trucks drove out of the darkness towards us. Dark-skinned people with black hats pointed guns at us and told us to lie face down and recite the Quran. We waited, expecting them to shoot us. They robbed us and drove away.

Three days in, US\$150 stolen.

\section{Iran}

Two days later we were in Iran. Baluch smugglers took over. ${ }^{4}$ They began with the rules: '1) Obey us at all times; 2) Don't speak; 3) Pay in advance; 4) Stay with the group; 5) Or die alone'. They had three Toyota pickup trucks, each crammed with about 20 passengers in the back. They drove too fast across the desert; we bounced in the back and became so caked in dust. We couldn't tell who was who. Our mouths were coated dry with dust. At stops, they didn't let us clean.

One boy was weak, vomiting, and with bad diarrhea. When we told the smugglers, they said that if he couldn't travel he'd be left in the desert. Usually we travelled at night, from near midnight until just before dawn. During the day, we were hidden in basements, farmhouses, stores, and petrol stations. At each location a new set of people took over. They made us clean toilets and carry stuff. We never had enough food or water. When I resisted, they beat me. About five days into the trip, one guy complained and they beat him nearly to death. After that we became quiet.

Sleeping was scary, we were so tired but anything could happen. We slept on the floor; sometimes they gave us straw mats. Someone stole my phone and US\$100 from my pocket while I slept, and it was probably the other passengers. We worried they'd abuse (rape) us while we slept, Ali especially.

Near the border, they locked me and Ali up in a stable with cows, sheep, and donkeys. They gave me a phone and made me call my family to tell the agent in Kabul to release the US\$1500 to Aziz's people. At the Turkish border

4 The Baluch are a large tribal community who live on the dry mountainous Iranian plateau between western Pakistan, southeastern Iran, and southern Afghanistan. 
we waited three days. Finally, when they had more passengers, Ahmed, Aziz's brother, came from Turkey to connect with us and took over.

23 days in, cost US\$1,750, including the security deposit released from the Kabul agent.

\section{Turkey}

Travel in Turkey was easier than in Iran. We didn't have to hide so much, but Ahmed, the new smuggler, was stingy and cruel. He gave us less food. He would lock me up, force me to clean toilets, and beat me if I complained. He was always grumbling about the cost of my food. He told my family to pay US\$800 more: US\$200 for a new phone, US\$200 for food, and US\$400 for travel. He got me a cheap phone and kept the extra money they sent him. One night, after waiting too long in Turkey, I got into an argument with Ahmed. I was weak and don't remember clearly, but I was ready to die. After this, I left the group along with Rafiq.

Rafiq is a little older than me, about 25 years old, and he is very smart. He speaks English, some Turkish and Norwegian, and had a good phone with GPS. He had lived in Norway illegally for five years, but made the mistake of coming back to Afghanistan for a wedding. We found two Afghan Turkmen smugglers, Arif and Bashir, who demanded US\$2500 to get me into Bulgaria. My family was told to pay this amount to an Uzbek carpet dealer in Kabul. After days of waiting at the border, two days before Eid (18 July), the money had been paid and we left for Bulgaria.

48 days since leaving Kabul, US\$4950 spent. Akbar's family in Kabul, fearing for his life, are now at the whim of random human smugglers.

\section{Bulgaria}

In a small village in Bulgaria, some young guys came up, threatened us and took our valuables; they even got my second phone. I wanted to defend our stuff, but Arif stopped me. Later, I refused to pay him all the money. He was supposed to protect us. The smugglers pointed us to a track through a field.

We walked four days through the forest until we got near Sofia, where we were arrested and were driven by the police for the rest of the way. The police fingerprinted all ten of my fingers. They asked us why we were there and whether we would stay in Bulgaria. We knew if we said we would keep going, they would let us go. Then they filled out a form. People told terrible stories about the Bulgarian police.

The police put us in a huge prison in the middle of a field with bars and razor wire, full of refugees from Syria, Iraq, Afghanistan, and Iran. At least we had regular food and mattresses, but the potato soup tasted like they had peed in it. 
After about 28 days, the guards collected us and asked if we wished to continue. When we said, 'Yes, to Germany; we will leave' they released us. Rafiq and I decided to travel alone, to take taxis, to try to blend in. My family wired US\$370 for a taxi. Two days later we got to Serbia.

We got arrested as soon as we crossed into Serbia and we were deported by train back to Sofia, Bulgaria. We rested there for about three days. This time, we took a taxi through the mountains to a bus station in a Serbian village. From there we hitched a ride to Belgrade.

78 days and US\$5365.

\section{Serbia, Hungary, and Austria}

A taxi driver said he could take us to the Hungarian border for 200 Euros. He asked us to turn off the GPS, and drove around for some time before dropping us at some smelly water. He told us to cross. When we turned on the GPS, we saw that he had just driven us around in circles because we were still in Belgrade. Eight or nine Syrians and Iraqis came towards us, refugees who had just been robbed. They were cold without clothes, and they looked abused.

We didn't realize this was about to happen to us. After crossing the pond, we saw the police waiting. We ran, but they unleashed dogs. I fell and almost drowned. The dogs bit us a lot but did not break the skin. Some really big guy sat on my chest and punched me. Rafiq told them he knew European law and that he would report them. This made them angrier.

They hung us upside down from a tree, stripped us naked, and beat us. They broke my hand.

My hand is still crooked and hurts. My jaw hurts too. The police, our attackers, searched our bags for money, and said we are evil Afghans coming to destroy their country. After some hours of abuse, they released us. We walked into a small village and fell asleep on the side of a street, exhausted. An old lady found us and brought us food.

We were arrested shortly after crossing into Hungary, driven to Budapest, and each of us had all ten of our fingerprints taken. After two days in prison, we were released. We got a cheap hotel.

After a while we got a ticket that took us almost all the way across Austria. We did not know where we were. We thought we were still in Austria and when the train stopped, I hid under the seat. A fat policeman picked me up using just three fingers. I had never been so afraid; I thought my heart would stop. When the police said we were in Germany, we were happy and relieved. Suddenly I felt more tired than I had ever known.

The entire journey took 93 days and cost $\$ 6815$.

A flight from Kabul to Frankfurt takes fifteen hours and costs less than $\$ 1000$. 
Figure 7.2 Akbar's Route to Europe

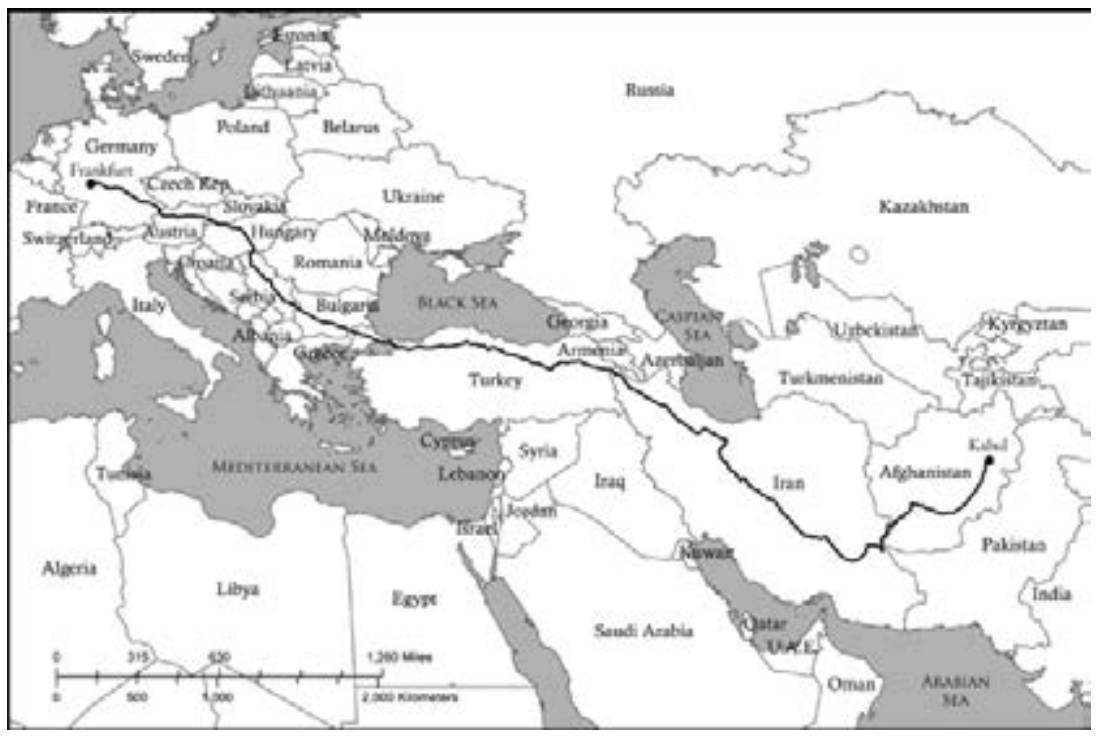

\section{Life in Germany: Tedium and Trauma}

From this first-person account of Akbar's life in flight, we return now to the third-person as we describe his adaptation to life in Germany. He arrived in Frankfurt three months after leaving Kabul, and was placed in a refugee hostel with other Afghans, Syrians, Iraqis, and Somalis. He takes German classes twice a week and plays soccer once a week. Summarizing his trip, Akbar said, 'If I had known Europeans were so unfriendly, I would never have left Kabul. Bulgarians, Hungarians, and Serbs are the cruellest people in the world, worse than any Afghan, even the Baluch. They are thieves and smugglers'.

He sounded depressed and traumatized, especially in the earlier interviews. His accounts jumped abruptly from topic to topic. He constantly worries about deportation, and most of the time he endures uncertainty, regret, and boredom, with nothing to do. Relations with his few friends at the hostel can be tense; with some others, they border on combative. He has nightmares and eats irregularly. He sleeps most days.

The trip was a mistake, he explained, at times bitterly blaming his parents for allowing him to come. The debt his family has incurred - enough, he believes, for his family to have bought a house - seems impossible to repay. He had planned to find work as a carpenter, but his broken hand makes 
that career uncertain. He shakes hands cautiously, using three fingers, to avoid pain. Over the three-month course of interviews between January and April 2016, his emotional state somewhat improved.

The shame of resuming life with his family in Kabul after failure and debt, especially in the honour-based Afghan culture, is too difficult for him to entertain for long. If forced to return to Kabul or to witness his two uncles abusing his family again, Akbar is not sure what he would do. Although these two uncles appear not to be active Taliban, they are thought to have associations with them, and continue to grow bolder in their demands and threats. Akbar says that returning to the insecurity of daily life in Kabul after the hardships and costs of his journey is impossible. Meanwhile, if given an opportunity to work and study in Germany, Akbar believes that he would one day prove himself and thrive.

In early April 2016, a representative of the German office that coordinates refugees gathered a group of twenty refugees from the hostel. They took a train to an immigration office, which Akbar described as a police station. Akbar was fingerprinted and photographed, his height and identifying features were recorded, and he responded 'yes' to the only two questions: 'Are you from Afghanistan?' and 'Are you a Muslim?' The process took ten minutes. He explained, 'I was so nervous, my hands were shaking, but when I was given that card, it felt like they gave me a million dollars'. He believed that the card meant that he would not be deported.

His family in Kabul was tremendously relieved that he made it to Germany, and deeply concerned about the prospects of his asylum application. Unlike previous generations of Afghan refugees, digital technologies make it possible for the family to be in frequent contact with Akbar en route, which is emotionally reassuring but financially devastating: continuous contact gives smugglers the upper hand, forcing the family to obtain more and more money in their efforts to keep their son safe.

His sister Kosar explained, 'We were worried about him, but we were also happy he might get a good education and better employment. Now that we know he is there, we are happy for him, though we know he might still get deported'. Both sisters say, without hesitation, that they would have gone if their family had allowed it. The whole family emphasizes the importance of the education that they believe Akbar will be able to get in Germany, an advantage of being there that rises above all others.

Masood, his older brother with whom he often fought, sometimes intensely, described Akbar since arriving in Germany as 'transformed', 
saying: 'Before he left he was a boy, but now he is sophisticated, polite, deep, and optimistic about the future. He gives advice to his brother and sisters, telling us how to treat our parents, and how to make the most out of life'. The authors believe that he has been more honest with us than he has been with his family about the hardships and dangers of the journey, and about his troubled state of mind.

\section{Conclusion: Uncertainty and Instability}

Statistics, images of refugee camps, and stories about European political tensions frequently appear in the media, but the family history and transit experiences of people who make the journey mostly escape the public eye and policy analyses. As a quarter million Afghans contend with uncertain futures in Europe, and a mass deportation of Afghans from Europe is in its early stages, we conclude this chapter with two arguments: first, that contemporary Afghan refugees need to be understood in reference to the duration of their national historical experience with conflict and displacement; and second, that the decision to deport large numbers of Afghans from European countries will further destabilize the volatile political circumstances in Afghanistan.

The European reception of refugees, particularly Afghans, grows colder by the day. Afghans were the second largest group of asylum seekers in Europe in 2015, with 196,170 applications. ${ }^{5}$ However, policy and legal questions intertwine with a growing fear of Muslims, security concerns, and xenophobic visions of Europe's non-white, non-Christian future. A central debate surrounding the growing discomfort with refugees in Europe turns on whether this influx of people are war refugees escaping violence and persecution, or economic migrants pursuing a better life. According to the 1951 Refugee Convention, a refugee cannot be sent back into circumstances where their life and freedom are threatened - the so-called non-refoulement principle (R. Jones 2016). But this simplistic binary has become outdated, and obfuscates both the multiple motivations of asylum seekers and the borderless movements of geopolitical problems in the early twenty-first century; consider as examples the multiple instigators of conflict in Afghanistan, or the borderless challenges posed by climate change (Parenti 2011). 
In mid-February 2016, central European countries began to deny Afghans access, creating backlogs and resentment. Soon after, Macedonia announced that Afghans would be classified as economic migrants and denied access, leaving thousands stranded at the Greek border. Serbia announced in late February 2016 that it had begun a policy of only accepting refugees from Syria and Iraq (Strickland 2016). Serbia, Slovenia, Austria, Croatia, and Macedonia then signed a joint statement restricting the flow of refugees, envisioning tighter restrictions over time.

Finally, in October 2016, the European Union and the Afghan government signed an agreement that allows the unlimited deportation of Afghans, with the EU using funding to leverage the Afghan government into compliance. The Afghan President Ashraf Ghani said dispassionately, 'I have no sympathy' for Afghan migrants (BBC 2016). Beyond the individual suffering, however, if tens of thousands of young Afghan men were to be abruptly and forcibly repatriated it would add kindling to a political environment that is already in flames, where the Taliban prey upon vulnerable and disenfranchised youth. The prospect of resuming life in Afghanistan is economically and emotionally devastating for deportees. Initial studies indicate that the majority would leave again, while some of those who remained would become addicted to drugs or involved in criminal/insurgent activities for money and opportunities (Siegfried 2016).

The EU-Afghan deal also raises questions about the non-refoulement obligations of European Union countries to house people at risk until the danger passes. In Afghanistan, the conflict is approaching a four decades since the Soviet intervention, and a decade and half since the US one. As we write, the Taliban possesses more territory than at any time since 2001. Kundoz City in the north fell briefly in late 2015. Lashkar Gah city, the capital of Helmand province in the south - where, not coincidently, nearly half of the world's opium is produced - has the Taliban at the city's edge and in control of most of the province. Suicide attacks, IEDs, and recent IS incursions challenge physical security and wreck confidence in the future, even in places where the government is firmly entrenched. The Asia Foundation's 2015 survey of the Afghan people found nearly 70 per cent of Afghans fear for their personal safety, the highest percentage since the survey began in 2006 (Asia Foundation 2015). In a war that all of the parties involved agree will get worse before it gets better, repatriating Afghans contradicts the EU's non-refoulement obligations.

The particulars of Akbar's story are unique, but most Afghan asylum seekers in Europe share the basic arc of his experiences. A family history of displacement due to past wars is the norm amongst Afghans. The high 
costs and abuses suffered while being smuggled across borders is also common. In particular, those who travel alone lose the emotional support of their family while adjusting to an unfamiliar culture, learning a new language, and feeling pressure to financially support their family - or repay the debt of the trip - as the possibility of deportation looms. And the journey itself can be psychologically devastating. Akbar was beaten multiple times, hung upside down naked, robbed, punched in the face, had his hand broken by policemen, and jailed, before he was settled into a building full of broken spirits existing at the whim of the German state's policy decisions on asylum.

The media tells a mostly Eurocentric story focused on water crossing, border defences, and international relations. Their photographs freeze victims in time. The dead wash ashore. Refugees cannot report crimes committed against them by the same authorities from whom they beg asylum. Following the life experiences and history of one Afghan family complicates the simple migrant/refugee divide, while reminding us of the duration of the Afghan conflicts and the complicated geopolitical origins of a 'war on terror'. By presenting the circumstances of a single family's struggle to survive across decades of conflict, our conceit is to keep the realities of war victims from being submerged by the abstractions of national interests and policy debates. In the end, after a harrowing and expensive journey, and despite a life in Germany defined by tedious uncertainty, regret, and loneliness, Akbar wants to stay in Europe. He says he would again risk his life to do so, at least until Afghanistan becomes secure: 'I am changed since I came to Europe; if I am deported back to Kabul, I will not stay.'

\section{References}

Al Jazeera (2015). Taliban threaten second Afghan provincial capital as insurgency spreads. Al Jazeera, 12 October.

Asia Foundation (2015). A Survey of the Afghan People. https://asiafoundation.org/ resources/pdfs/Afghanistanin2015.pdf

Azamy, H. and Weir, J. (2015). Islamic State and jihadi realignments in Khorasan. The Diplomat, o8 May.

Barfield, T. (2010). Afghanistan: A Cultural and Political History. Princeton: Princeton University Press.

BBC (2016). President Ghani: 'No sympathy for Afghan migrants'. British Broadcasting Corporation, 31 March. 
BBC (2016). Migrant crisis: Migration to Europe explained in seven charts. British Broadcasting Corporation. 4 March.

Ewing, P. (2017). Thousands more troops needed to break Afghanistan 'stalemate,' general warns. National Public Radio, 9 February.

Gall, C. (2014). In Afghan election, signs of systemic fraud cast doubt on many votes. The New York Times, 24 August.

Jones, R. (2016). Violent Borders: Refugees and the Right to Move. New York: Verso.

Jones, S. (2016). U.S. commander: 12 terrorist or 'extremist' groups now operating in Afghanistan. The Christian Science Monitor, 29 July.

Linschoten, A. and Kuehn, F. (2012). An Enemy We Created: The Myth of the Taliban-al Qaeda Merger in Afghanistan. Oxford: Oxford University Press.

Parenti, C. (2011). Tropic of Chaos: Climate Change and the New Geography of Violence. New York: Nation Books.

Patan, M. (2007). Ghazni: Land of Mystics. Ghazni: Governorate of Ghazni Publications.

Rasmussen, S. (2014). Kabul - the fifth fastest growing city in the world - is bursting at the seams. The Guardian, 11 December.

Sidahmed, M. and Ackerman, S. (2016). Afghan forces lose ground to Taliban despite delayed US troop withdrawal. The Guardian, 29 July.

Siegfried, K. (2016). What became of 25 young Afghan deportees? IRIN News, 6 April.

Strickland, P. (2016). Serbia 'denying entry' to Afghan refugees. Al Jazeera, 21 February.

Weir, J. and Azamy, H. (2015). Economic impediments to a Taliban peace process. The Economics of Peace \& Security Journal, 10(2), pp. 75-84.

Zahid, F. (2015). The successes and failures of Pakistan's operation Zarb-e-Azb. Terrorism Monitor Journal, 13, pp. 5-6. 


\section{About the Authors}

James Weir has a Ph.D. in cultural anthropology from the Graduate Centre at the City University of New York. His dissertation 'We Went to the Hills': Four Afghan Life Stories uses life narratives to examine the lived histories and emotional legacies of the Soviet war period. His interest in the region began over two and half decades ago as a US Peace Corps volunteer in Balochistan, Pakistan and he continues to write on and work in the region.

Rohullah Amin is a medical doctor and psychologist by training. He conducts independent social psychological research focused on war and peace psychology in the context of Afghanistan and the impacts of the conflict on the collective psyche. Amin studied applied psychology at New York University (2011-2013); before that, he studied at Kabul Medical University (2004-2010). He is currently serving as the director/senior research fellow at the American Institute of Afghanistan Studies. He has also taught at the American University of Afghanistan. 



\title{
$8 \quad$ Hardening Regional Borders
}

\author{
Changes in Mobility from South Asia to the European Union
}

Marta Zorko

Jones, Reece and Ferdoush, Md. Azmeary (eds), Borders and Mobility in South Asia and Beyond. Amsterdam: Amsterdam University Press, 2018 DOI: $10.5117 / 9789462984547 / \mathrm{CHO} 8$

\begin{abstract}
This chapter provides an overview of how European Union states on the migrant route deal with migrants from South Asia. The militarization, securitization, and hardening of borders in Europe influenced all types of migration and changed the perception of migrants from many different regions of the world. The return of physical barriers and border controls created new geopolitical patterns of movement. The chapter analyses how and to what extent these processes have affected migrations within Europe and from South Asia to Europe. The aim is to show both quantitative and qualitative changes by analysing the trends and presenting an overview of migration patterns, problems, and challenges from the perspective of migrant rights, chances, and possibilities.
\end{abstract}

Keywords: geopolitics of migration, European migration crisis, securitization of borders, migration patterns

\section{Introduction}

In 2016, the refugee crisis demonstrated new trends that highlighted crucial issues for future migration processes in Europe. My first encounter with the crisis itself was in 2015, when I was at a conference in Budapest, Hungary. Rumours about refugees from South Asia and Syria arriving in the Budapest city centre and officials closing the railway stations circulated among the conference participants and guests. Soon the story was confirmed, when refugees began to march towards Germany over the Erszebet Bridge because of the closed railways and the lack of organized transport to their destination (Hardman 2015). A few days later, Hungary closed its borders and erected razor wire barriers on its borders with Serbia and Croatia. With the way 
from Serbia to Germany through Hungary closed, the main flow of people was redirected towards my home country, Croatia. The first transit camp was built in Opatovac, next to the Šid-Tovarnik border crossing between Serbia and Croatia. Although there was a lot of information about them in the Croatian media, the refugees themselves were not visible in other parts of Croatia. Later, when a new transit camp was built next to Slavonski Brod due to the weather conditions and inability to house more people in the existing camps, the possibility of meeting or even seeing a refugee was limited to officials and volunteers in the camp. There were many different stories in both the Croatian and world media about the living conditions and human rights of the refugees in the camps along the Balkan route. As horror stories about the conditions in Greek and Macedonian camps reached their peak, I began to research the situation in the refugee camps along the Balkan route, from Greece to Germany via Croatia.

I made a field visit to the transit camp in Kilkis, Greece in the middle of February 2016 and another to the transit camp in Slavonski Brod, Croatia two weeks later, at the end of February 2016. I then made a third visit to Fürstenfeldbruck, Germany in late September 2016. All of this field research consisted of reconnaissance into the living conditions in and the models of organization of the settlements. During the field visits, I conducted semi-structured interviews with ten state officials. ${ }^{1}$ The first research trip included part of the Balkan route from Croatia, via Serbia and Macedonia, to Greece. The second was focused solely on transit camps in Croatia: Opatovac, which was already closed, but kept on standby in case of need; and Slavonski Brod. The focus of the third research trip was to compare the refugees' living conditions in the destination countries, rather than solely the transit ones.

Differences in organization and patterns of behaviour were immediately visible between the different sites. In Greece, some refugees were settled in official guarded, organized, and closed camps with mostly adequate infrastructure; others were living in unofficial, randomly erected settlements

\footnotetext{
1 The first interview was with a policeman on the border between Serbia and Macedonia; the second was with a customs officer on the border between Macedonia and Greece. My requests for interviews in Greece (at the gate of the Kilkis camp and from the taxi driver outside the camp, waiting in the line to take the refugees to the border) were refused. During the second field visit, I conducted five interviews: two with the county spokespersons of the Ministry of the Interior of Croatia; one with an individual from the National Protection and Rescue Directorate; and two with volunteers inside the transit camp in Slavonski Brod. I conducted three interviews in Germany with military personnel employed at the Fürstenfeldbruck military base, part of which has been transformed into a detention camp. Since a majority of the interviewees requested anonymity, only their functions will be mentioned in this chapter.
} 
of tents. In absence of infrastructure next to the roads, gas stations often served as hubs of these unofficial settlements, providing electricity and water supplies. The refugees were often seen walking along the roads and highways towards the north. The situation was similar in Macedonia, where refugees settled themselves in unofficial camps near the border crossing. In Croatia, however, the experience was quite the opposite: the ongoing organized transit to and from the transit camp made the refugees virtually invisible to the local population. This is why, I propose that the Croatian example of handling the crisis could be named 'the silent transit', a concept explained in detail below.

Several trends are already evident from the 2016 European Union crisis. First, the official state responses to such a human crisis almost uniformly took the form of using security mechanisms to harden regional borders. Second, the securitization and militarization of the crisis, the negative discourses about migrants, and the lack of solidarity between the member states of the EU will have an important influence on further migrations to Europe. Third, official state policies show clear geographical patterns that appear to be related to the proximity of the member state to the refugee flow: sites of transit, targeted (destination) countries, and those which were indifferent to the crisis. States' willingness to respond to the crisis depended upon their exposure and geographical proximity to the migrant flows.

This chapter analyses these geopolitical patterns of behaviour to develop categories of EU member states in terms of their actions and the mechanisms they utilized (which reveals the importance of territorial proximity and geography in this case), and the lack of solidarity between EU member states. Both factors will impact future migrations to Europe. The behaviours of transit countries are examined through the comparative analysis of two responses to the arrival of refugees: building barriers and creating a system of official transit. These two responses are starkly different approaches, but, somewhat surprisingly, produced similar results. In this chapter, the focus is on South Asians' migration experiences as they passed through these new routes in search of a different life in Europe.

\section{Geopolitical Patterns of Migration}

Jakub Marian argues that the refugee crisis has not yet significantly changed the overall picture of migration in Europe (2016). Prior to the refugee crisis, migration mainly consisted of internal movement between European countries and within EU member states. With the exception of the United Kingdom, which saw the highest influx from South Asia (India is the most 
common country of origin of the foreign-born population in the UK), the foreign-born population in Europe comes from countries on the European continent or in its close neighbourhood. A geographical pattern that could be called 'one step ahead' sums up European inner migration trends, which mainly move from east to west. This means that neighbouring countries are the most usual destination for migrants. For instance, the most common origin country of the foreign-born population in Poland is Ukraine, while in Germany it is Poland. A second pattern visible in Eastern Europe is part of the legacy of the Cold War. Russia stands out as the country of origin of most migrants in a wide bloc spanning from the Baltic States to Ukraine and Bulgaria. In Western Europe, traditional relations create more patterns, such as migration from Morocco to Spain, and from Algeria to France. There are also some cyclic migration patterns visible in regional dynamics, mostly on the Balkan Peninsula, Scandinavia, and the German-speaking areas that were historically called Mittleuropa. Despite the refugee crisis, these longstanding patterns still prevail; the most frequent countries of origin have remained mostly the same (Marian 2016). Although the dynamics of regular migrations in Europe have not seriously changed, the refugee crisis has created tensions between EU member states and their neighbours. The crisis has defined new patterns of action and generated geopolitical discourses that will influence future perceptions of migration in Europe.

The refugee crisis has sparked the hardening of internal European borders. Since the external European Schengen border is not yet final (Croatia is EU member state but not yet member of Schengen Agreement), the discontinuation of the Schengen space caused a domino effect of razor wire building and tightening border controls between EU member states. Inside the Schengen zone, different groups of states reacted to the refugee crisis in different ways, most commonly through a temporary suspension on the Schengen agreement and the imposition of strong control on their own national borders. Such processes could be explained through both contemporary theories on borders as a social phenomenon and as a question of securitization. Borders as social phenomenon implies their possibility to transform in social interaction while securitization implies change towards the hardening of border regimes in the time of crisis. Anssi Paasi defines borders not through the postmodern understanding of the world, but as phenomena that occur in practice. In this sense, borders cannot be understood as fixed and stable, but rather as processes embedded in social activities and discourses (Paasi 1998). If we understand borders as a process that changes, the change can easily be shifted in other directions. Once softened, borders could be hardened again. The hardening of borders and reversing to the traditional understanding 
of borders ${ }^{2}$ is often seen in times of crisis or changes in power relations in the wider region ${ }^{3}$. During the refugee crisis, some countries actually experienced a decrease in migration - which can be explained through their implementation of isolating and nationally oriented border politics as a response to the crisis. One example of this is Hungary, where the rate of migration is falling below the average before the recent refugee crisis. ${ }^{4}$

The so-called 5 'return of geopolitics' (Mead, 2014), in Europe was evident from geographical divisions and power relations. In the current refugee crisis, geographical and geopolitical patterns of the phenomena are more than visible and will be further elaborated. In addition to security concerns, however, the willingness to help also shows patterns related to power and geography. The first geographical division is between EU member states and non-EU member states. Although the European Union territory is otherwise rather compact, it is discontinuous in the Balkan Peninsula. This geostrategic weak link has been recognized in this and other cases (not only in terms of criminal activities and migration paths). Second, and specifically with reference to the refugee crisis, European countries can be divided into three major categories based on the perspective of the refugees: transit countries, targeted (destination) countries, and indifferent countries. Each of these categories demonstrates a strict geographical pattern based on their proximity to the refugee flows.

\section{Transit Countries}

The transit countries are primarily countries in south and southeast Europe, namely Turkey, Greece, Macedonia, Serbia, Croatia, Hungary, and Slovenia. All of these countries in the Balkan route reacted in similar ways to the refugee crisis: by dealing with the crisis without helping to solve the wider problem. These countries were not the destinations of the refugees, as they never meant to stay or seek asylum there. Nevertheless, some of them reacted in a way that no one could predict - by closing their borders and building

2 Traditional understanding of the border implies that they are strict formal lines between two states strongly depending on bilateral relations and international odrer in particular time. Contemporary understanding of the borders goes beyond such an narrow definition, including borders as processes instead of firm lines of demarcation between two entities.

3 The Concept of the Wider Region refers to the regions inclining to the Region in question. Since regions often overlap, the neighboring regions are also under the influence of power relations in question.

4 International Organization for Migration, Hungary website, www.iom.hu, 9/1/2017.

5 The term so-called Return of Geopolitics is used because Geopolitics never left the academic scene or political arena. Even in the decade of Endisms (Huntington, 1989) geopolitics never lost its importance. 
fences to redirect refugee flows out of their territory. Razor wire fences are not new in this part of Europe; in 2012, Greece built such a fence at a rather popular crossing point to block migrants arriving from Turkey (Almukhtar, Keller, \& Watkins 2015). This barrier redirected the migrant flow in two directions: by sea towards the Greek islands, and by land towards Bulgaria. Bulgaria reacted in a similar way, by building fences on its own border with Turkey in 2014 (Almukhtar, Keller, \& Watkins 2015). In 2015, at the very beginning of the refugee crisis, Hungary also built a razor wire fence, first on the border with Serbia, and a month later on the one with Croatia. Hungary's plans for building a fence on the Romanian border are currently on standby, since the overland Balkan route is temporarily closed. Slovenia also reacted by building fences with a razor wire barrier along the border with Croatia.

The second model of reaction by transit countries was what could be termed 'fast transit'. Macedonia, especially after the police crackdown ${ }^{6}$, has focused on quickly moving migrants north, to Serbia (Almukhtar, Keller, \& Watkins 2015). Serbia has reacted in a similar way by transferring them on to Croatia. In both instances, the governments created transit camps and provided transportation services to move people through the country and to the next border on their route to Germany and other destination countries.

Croatia, as a member of the EU but not yet a member of the Schengen system, became one of the main transitional routes for the migrant flow. Hungary's construction of a razor wire fence on its borders with Serbia (a non-member state) and Croatia (a member state, but not yet a Schengen country) closed one of the main migration routes. Slovenia also installed a razor wire fence on the border with Croatia. Together, these fences shifted the focus of the migrant crisis towards the Croatian borders. Croatia did not build a fence (although it was frequently mentioned in Croatian public debates as plan $B$, or even plan $C$ ), and instead did everything to make the transit of people as invisible as possible. In this case, it could be called 'a silent transit'. The refugees arrived by train at an old industrial complex on the border that had the needed infrastructure, they stayed there for a few days or even less, and were quickly transferred to the Slovenian border. The transit camp was situated far from the main roads or local people; other than through the media, the refugees had no contact with the local population or any opportunity to impact the discourses surrounding their movement.

6 The police crackdown in Macedonia happened between police and migrants upon the state decision that only migrants from the war zone in Syria would be allowed to pass. After the physical encounter in 2016, there were over 50 Afghans trapped in no-man's land between Serbia and Macedonia (Cook, 2016). 
The Croatian experience as a transit country was twofold. In the context of official state policies and international politics, as well as regarding the relations with its surrounding European states, Croatia was considered a 'success story' (European Economic and Social Committee 2016: 7). Crisis management experts agreed that the refugee crisis was handled successfully, considering the circumstances. ${ }^{7}$ Despite the sometimes-high numbers, the flow of refugees caused neither major problems in the state's functioning nor any reports of human rights violations. Refugees entered Croatia by train, were registered and taken care of, had the possibility to request asylum in Croatia or look for their family members if lost, and left Croatia by train towards Slovenia border. The transit camp was organized and functioned at a high level of order and discipline, and provided all the supplies the refugees needed: food, water, clothing, shelter, if wanted, and free internet connection. The key characteristic of the transit camp in Croatia was the speed of the transit. The majority of refugees spent no more than a few hours in the camp. Only a limited number stayed overnight, and even fewer for a few days. ${ }^{8}$ Such procedures seemed to suit both the officials in the Croatian camp and the refugees, since they were transferred as quickly as possible towards their desired destination countries. Also, there were no major incidents or problems in the camp. ${ }^{9}$ From the perspective of security, official discourse, and public opinion the refugee crisis was handled well in Croatia. Croatia imposed no border walls or physical obstacles, controlled the flow of people, and transferred them as soon as possible towards their desired destinations.

Nevertheless, from the perspective of human rights and human dignity a few questions could be raised. The location of the winter transit-reception centre in Slavonski Brod could seem logical due to the border proximity and the direction(s) of the refugees' flow. The camp was situated in an old industrial complex in Bjeliš, several kilometres from Slavonski Brod. Bjeliš has all of the infrastructure needed for transportation, most importantly rail lines. It is also an isolated and sparsely inhabited area, which ensured that the local population would have no contact with the refugees whatsoever. Such isolation prevented potential negative reactions from local population and diminished the feeling of a 'state of emergency' experienced by some

7 Interview with individual associated with the National Protection and Rescue Directorate, February 2016.

8 Interview with a spokesperson from the Ministry of Interior for Brodsko-posavska County, February 2016.

9 Except for a few attempts to escape from the camp. Interview with a spokesperson from the Ministry of Interior for Brodsko-posavska County, February 2016. 
other transit countries. On the one hand, this 'invisibility of the refugees' prevented the proliferation of negative discourses about the migration crisis in the public sphere; on the other, information was limited to that presented in the media or gained from official state sources. Such isolation would not be helpful in the long term considering the possible future integration or assimilation of the refugees in Croatia.

Before Slavonski Brod was introduced as a transit camp for the refugees, an ad hoc camp existed in Opatovac, near the border-crossing town of Tovarnik. At that site the Croatian army, Red Cross, and National Protection and Rescue Directorate built a camp that could host up to 4800 people at once. ${ }^{10}$ This camp was temporarily closed in November 2015 due to the need for more space, weather conditions, and official state politics (Patković 2015). The new transit camp in Slavonski Brod has a capacity to host up to 5000 people at once, but during times of the highest flow up to 9000 people went through the camp every day. ${ }^{11}$ Altogether, over 660,000 people went through Croatia from September 2015 to February 2016. It is estimated that over 350,000 people went through the transit camp in Slavonski Brod, while 314,400 people went through Opatovac during the first three months of the crisis. ${ }^{12}$ During my field visit to Slavonski Brod in February 2016, the daily influx rate was between 1000 and 3000 people; at the beginning of the refugee crisis, it had ranged from 6000 to 9000 people. ${ }^{13}$ The largest number of refugees processed in a single day was 11,670 , on 24 October $2015 .{ }^{14}$ Statistical data of the registered refugees who entered Croatia in Vukovrasko-srijemska County showed that they were mainly (62.5 per cent) male. ${ }^{15}$ During the time of crisis, the top five countries of origin of the refugees registered in Croatia were Syria (51.32 per cent), Afghanistan (28.73 per cent), Iraq (13.53 per cent), Pakistan (2.39 per cent), and Bangladesh ( 0.4 per cent). Other nationalities together made

10 Interview with National Protection and Rescue Directorate person, February 2016.

11 Interview with a spokesperson from the Ministry of Interior for Brodsko-posavska County, February 2016.

12 Interview with a spokesperson from the Ministry of Interior for Vukovarsko-srijemska County, February 2016.

13 Interview with a spokesperson from Ministry of Interior for Brodsko-posavska County, February 2016.

14 Interview with National Protection and Rescue Directorate person, February 2016.

15 This sample consisted of 33.1 per cent of the total number of refugees who entered and registered in Croatia. Among the total number of $115,15^{8}$ people, there were 71,930 men $(62.5$ per cent); 15,088 women (13.1 per cent), and 28,140 children (24.4 per cent). Interview with National Protection and Rescue Directorate person, February 2016. 
up 3.63 per cent. ${ }^{16}$ The problem with the official data is that only around 20 per cent of the refugees had any kind of identification cards or travel documents. ${ }^{17}$ Of those that did have documents, over 30 per cent were from South Asia.

The transit camp in Slavonski Brod was closed in April 2016, and the remaining refugees were taken through a detention camp in Ježevo and hotel Porin in Zagreb. Official numbers show that Croatia was definitely not a destination country: the total number of people seeking protection in Croatia in 2015 was only 152 among whom the number of refugee asylum seekers were even lower. ${ }^{18}$ The official data for the first three months of 2016 shows the influence of the crisis and pressure on the Balkan route, but not significantly in the sense of changing the amount of interest in seeking asylum in Croatia. ${ }^{19}$

Some cases of the asylum seekers could truly describe the emotional and human components beyond the discourses of the securitization of migration and borders. The camp in Ježevo, named the 'Reception Centre for Foreigners' was used for persons with legal issues before the crisis. It is a closed and isolated institution. ${ }^{20}$ Other locations were the hotel Porin in Zagreb and the receiving centre for asylum seekers in Kutina. As a part of European Union and future Schengen member, Croatia had started to build detention centres for migrants in Trilj and Tovarnik with EU funds. Croatia has received 120 million euros from the Schengen Facility to meet the standards for the

16 The numbers are as follows: Syria 59,097 people, Afghanistan 33,092 people, Iraq 15,557 people, 2748 Pakistani, and 425 people from Bangladesh. With the number of 4219 people of other nationalities it makes a sample of total 115,158 people that entered Croatia in first two months of the crisis. Statistical data from the National Protection and Rescue Directorate, provided in interview with National Protection and Rescue Directorate person, February 2016.

17 Interview with National Protection and Rescue Directorate person, February 2016; confirmed by spokespersons from the Ministry of Interior. They list this issue as a top challenge for the official statistics.

18 There were 135 male and only seventeen female protection seekers. The top ten countries of origin of international protection seekers (by number of individuals) in 2015 in Croatia were: Algeria (21); Syria (18); Nigeria (11); Morocco (9); Serbia (7); Afghanistan, Iraq, Kosovo, and Turkey (6); and Azerbaijan, Bosnia and Herzegovina, Iran, and Ukraine (5). Twenty more countries of origin had less than five international protection seekers. Official Ministry of Interior Statistics. 19 In those three months, 379 people sought international protection in Croatia. The malefemale ratio also improved, to approximately three-to-one. The top ten countries of origin also changed, pointing to the effect of the refugee crisis. The top ten countries (by number of individuals) were: Iraq (134); Afghanistan (76); Syria (49); Iran (31); Algeria and Morocco (17); Somalia (11); Pakistan (10); Turkey (6); and Lebanon, Nigeria, and Serbia (4). Eleven more countries each had less than three international protection seekers. Official Ministry of Interior Statistics. 20 It was where foreigners who had been denied asylum waited for deportation. Official Ministry of Interior website. 
supervision and control of external borders of the European Union (Pavlić 2016). Some of those funds were used for building closed detention centres for migrants. However, these reception centres are often called 'prisons' by civil society networks, since foreigners have limited movement possibilities (even after receiving asylum) and are guarded by police or security forces (No Border Initiative Zagreb 2016). Ježevo is often called just another detention prison and it is listed in the Migreurop 'Close the Camps' Initiative. ${ }^{21}$

Meanwhile, the official statistics show that it is not easy to get international protection in Croatia. In 2015, only 36 out of 152 asylum requests were granted, which is 23.7 per cent. Together with seven subsidiary protections it makes 43 cases out of $15^{2}$ positively solved. The numbers for the first three months of 2016 are even more dramatic: from 379 requests for asylum, only two were granted. ${ }^{22}$ My informal discussion with asylum seekers housed at the Hotel Porin in Zagreb showed that there were multiple issues with their treatment on all levels, including housing, life conditions, hate speech, physical abuse, raids, right of movement, and other granted human rights.

Regardless of the positive or negative impact of such policies towards refugees in terms of creating or decoding the discourses about them, the geographical position of Croatia as a transit country between the integrated and the non-integrated parts of Europe influenced the selection of these actions and policies. The historical position of periphery and the current position of 'double borderlands' affected the measures and actions in this case as well (Zorko 2015).

\section{Target (Destination) Countries}

The targeted or destination countries for the migration of the refugees were the Scandinavian and central European countries, primarily Germany. These countries accepted the refugees through the implementation of more or less successful policies and procedures. However, the refugees' integration into these societies remains a huge challenge. My field visit to Fürstenfeldbruck (Germany) in late September 2016 showed that integration is a time-consuming process for both refugees and the local population. Situated in a converted military base, it became obvious that this camp

21 Migreurop is a network of associations, activists and researchers from countries in the European Union, Sub-Saharan Africa, North Africa, and the Middle East founded in 2002. The network deals with human rights issues regarding the exclusion of migrants in Europe. They have been mapping detention prisons and camps in wider Europe.

22 Official Ministry of Interior Statistics. 
was only a temporary solution. The lack of communication and contact generated discourses that cannot fade away easily.

\section{Indifferent Countries}

The third group of countries consists of those that were not affected by the current refugee flow, mostly located in southwest (specifically Portugal and Spain) and northeast (The Visegrad Group and Baltic countries) Europe. These countries did not show the will to act, or interfere, in the refugee crisis unless it was absolutely needed. Although Spain and Italy are under pressure from different migration paths, they were excluded from this particular refugee crisis. The former Visegrad countries acted along with Hungary offering help in protecting the southern border and closing the possible path through their territory (Kasnota 2016). This is another proof of the lack of European solidarity, and could be interpreted as a European failure to act unanimously in a crisis.

Regardless of the geopolitical imaginations embedded in the terms of the North, South, East, and West, the geographical pattern in this case is strict and nation-state oriented. Adding power and politics to this geographical equation, the countries can again be classified into two major categories and several subcategories as stated in abovementioned geographical patterns. The countries of Eastern Europe closed themselves to the migrants' flow through different alliances and declared themselves closed to cooperation through, for example, the installation of razor wire fences. Among the target countries, some EU non-members (Switzerland, Lichtenstein, Iceland, and Norway) requested quotas and had a will to engage with the crisis. The transit countries, especially the non-Schengen countries, managed the crisis on their own through numerous plans and policies declared at a national level. These plans mainly involved national security and led to the militarization of the issue. A lot of tensions undermined any attempt on a coherent and united plan at the level of the EU. The non-affected countries stood aside, watching the implosion and building of the fences between member states. The project of 'Europe Without Borders' failed when it was most needed. Instead, in the time of crisis, European (dis)unity showed its true face once again. The solidarity as an idea some member states relied on, failed completely for the second time in a very short period. ${ }^{23}$ Both times it failed on important issues of European unity and identity.

23 The first time that european solidarity was tested during the 2008 financial crisis. Lack of burden-sharing in case of PIIGS countries is similar to lack of solidarity with destination countries 


\section{South Asian Migration to Europe}

There are two major patterns of migration from South Asia (primarily India, Bangladesh, Pakistan, and Afghanistan) to Europe: regular migrations that have been ongoing for decades; and those related to the current crisis.

Of the South Asian migratory flows to the Global North, 'the one to Great Britain has the longest and most distinctive history. The 1948 Nationality Act in Britain, passed at a time of labour shortages within the country, allowed unrestricted entry to Great Britain for the citizens of the realm's former colonies' (Kibria 2011). While British immigration policies became increasingly restrictive in the 1960s and 1970s, large populations from former colonies had already settled in the UK. In the United Kingdom, 'the average number of acceptances for settlement in the 1970s was 72,000 per year; in the 1980s and early 1990s it was about 54,000 per year' (Migration Watch UK 2017). In the late 1990s, the numbers increased rapidly, reaching 156,000 by 2004, after which there was a slight decline. It has been argued that most early 'New Commonwealth migrants' were British settlers and colonial officials with their descendants returning from Britain's former colonies (Migration Watch UK 2017). India, Poland, and Pakistan are currently the top three countries of birth for the foreign-born population in the UK. ${ }^{24}$ Moreover, India is the country of birth for 9.3 per cent of all foreign-born persons living in London; other South Asian countries - Pakistan (4.3 per cent), Bangladesh (3.1 per cent), and Sri Lanka (2.3 per cent) - fall in the top ten countries in terms of the birth of migrants currently living in London. ${ }^{25}$ The historical and geopolitical gravitation of former colonial relations is noticeable in the case of India, Bangladesh, and Pakistan.

The refugee crisis of 2015 also influenced the traditional and regular migration flows in United Kingdom. Not geographically included in the flows of the migration crisis, and not even politically obliged any more, 'UK's historically distinctive position within the EU has deepened in part due to migration concerns' (International Organization for Migration 2015: 4). Migration issues were highly relevant in the BREXIT debate as well: the

in the 2015/2016 migration crisis. The difference is only in the reasons, or the background, for the lack of solidarity between member states.

24 '[A]ccounting for 9.2, 9.1 and 6.o per cent of the total population, followed by Ireland and Germany. India and Poland remain the top two countries of citizenship of foreign citizens, with Poles being the biggest group, accounting for about 15 per cent of the total' (Rienzo and Vargas-Silva 2015).

25 Exceedingly, 'Poland, Romania, Ireland, and Italy are the four European countries in the top ten. With the exception of Italy, Romania, and Jamaica, the remaining top-ten countries of birth for migrants in London are also top-ten countries at the UK level' (Rienzo and Vargas-Silva 2015). 
UK's decision to 'opt out of the European relocation mechanism for migrant and refugee arrivals in 2015, its selective participation in EU migrationrelated policies and the referendum on EU membership itself in June 2016 demonstrate the UK's ongoing efforts to negotiate migration concerns in relation to the EU' (International Organization for Migration 2015: 4). The New Immigration Act came into force in 2016 and introduced new measures intended to prevent irregular migrations (International Organization for Migration 2015). Later on, the Strategic Plan introduced the relocation quota for up to 20,000 refugees from Syria by the year of $2020 .{ }^{26}$

Outside of Commonwealth connections, regular migrations from South Asia to Europe have its strong connection in Bangladeshis migrating towards Italy. The number of Bangladeshi migrants living in Italy has reached 84,000 in 2009, while the number of (regular) Bangladeshi migrants was projected to reach 232,00o by 2030 (Blangiardo 2009: 35, 49, quoted in Rahman \& Kabir 2012). After Britain, Italy has the second largest Bangladeshi community in Europe, counting 140,000 in $2016 .{ }^{27}$

The pattern of South Asian migration to Europe during the 2015 refugee crisis primarily featured origin countries of Afghanistan and Pakistan. These movements followed the same path as others during the refugee crisis, but the numbers and statistics are not yet transparent and final. ${ }^{28}$ Migrants from Afghanistan, Pakistan, and Bangladesh made up more than one third of the total people transferred through Croatia towards the destination countries. ${ }^{29}$ The official data on asylum seekers in Croatia in the first part of the 2016 showed that there were more Iraqi and Afghan than Syrian asylum applicants. The main reason for such a high number of asylum seekers from Afghanistan in Croatia could be rationalized through Croatian involvement in NATO International Security Assistance Force mission. The crisis highlighted a new pattern for South Asia migrants to Europe, as well as new destination countries for the future.

26 'Despite anxieties over immigration, in response to the volatility in the Middle East and the large-scale movement of Syrian refugees across Europe, the British public called for an increase in resettlement of Syrians. In September 2015 the UK Government announced the expansion of the Syrian Vulnerable Person Resettlement scheme to resettle 20,00o Syrians from the Middle East and North Africa (MENA) region by 2020' (International Organization for Migration 2015:5). 27 Migration from Bangladesh has been ongoing since the country's formation in 1971. The reasons are explained in economic dimensions: 'the high oil prices in the 1970s boosted industrialization in the Middle East, and created a new migration system drawing mostly on north African and south and southeast Asian laborers' (Von Rohr and Delaney 2016).

28 The issue of migrants and refugees entering Croatia without proper documents leave room for statistical errors and miscalculations. Interview with National Protection and Rescue Directorate person, February 2016.

29 Interview with National Protection and Rescue Directorate person, February 2016. 


\section{Instead of a Conclusion: Real-life Chances for Integration}

The Schengen space has become a powerful symbol of European unity and success after the division of the Cold War. It seemed that a united space of inner mobility could not be questioned, regardless of the challenges beyond that firm wall. The Schengen project was a symbol of accomplishment from within, and the object of jealousy and desire from without. Siniša Kuko even calls it 'The Crystal Wall', since it was firm and transparent so that the 'Others' would be able to see the greatness of the European Union (2006). Regardless of such strong symbolism, however, the refugee crisis negatively affected European unity and solidarity. The temporary abolishment of the Schengen agreement, the hardening of Europe's inner borders, strong border controls, and even fence building have shown that in times of crisis a nation-centred discourse will prevail over international unity and common values.

The first and most important outcome was the process of hardening the internal borders between the EU member states. The process of reshaping the borders undoes decades of rethinking the concept of the border from a critical perspective, which had diminished the importance of national borders in Europe. Hardening the regimes of border security led to militarization in two ways: first, the visible militarization of soldiers guarding razor-wire fences at the borders; and second, the securitization and militarization of the refugee crisis in everyday discourse. The latter will have much deeper consequences for the future perception of migration processes in Europe.

The refugee crisis also led to a redefinition of laws, practices, and mechanisms in the European Union. The discourse of crisis led to the securitization and militarization of the issue itself. The suspension of positive legislation in the EU (the Schengen agreement and the Dublin criteria), pointed out that such laws have had never really been tested and were not the results of real intentions and a true will of the member states in the first place. Since they were never designed for this type of crisis, they were not able to function properly. Moreover, there were legal and technical obstacles and a lack of will: the member states behaved as if some aspects of the crisis did not concern them and closed the shells of their respective national security frameworks rather than tackling the issues.

The securitized and militarized refugee crisis evoked even more negative discourses towards migrants. The question of migrant rights versus real chances and possibilities of integration into European societies will be the key issue of the future migrations to Europe. Discourses of Others in Europe are not new ones. The changing perspective of who represents Others might 
change, but discourses and attitudes towards the Others will remain the same. The real issues that Europe will face are questions of inclusion and integration, as well as questions related to the new and old minorities in Europe. Even in the UK after BREXIT, questions on migration, migration policies, and the Commonwealth remain unanswered - despite the vital place of migration issues and EU regulations in the BREXIT debate prior to the referendum. A balance between acceptance, asylum, regulations, and rights will define the future of migrations within and towards Europe. For example, the Hungarian referendum on the abolition of EU quotas for the resettlement of asylum seekers was unprecedented in European affairs, and was sparked by the refugee crisis - it was even named a 'referendum on migrants' by the media. The conditions of life in and around the five hundred detention camps for foreigners in Europe and future perspectives for new migrants still need to be discussed and solved by the EU member states.

Further, the differences in the actions and policies of member states could influence the future of the Union itself. The next phase will relate to issues of social inclusion; this is going to be the real test for the member states and the European Union in general. The ability to cope with such challenges will define future migration flows both within and towards Europe.

\section{References}

Almukhtar, S., Keller, J., and Watkins, D. (2015). Closing the back door to Europe. The New York Times, 16 October.

Blangiardo, G. (2009). Foreigner's presence in Italy: From a reference framework to future development scenarios. In: V. Cesareo, ed., The Fifteenth Italian Report on Migrations. Polimetrica: Milan.

Cook, L. (2016). EU, UN criticize Balkan police crackdown on Afghan migrants. Business Insider. http://www.businessinsider.com/ap-eu-un-criticize-balkanpolice-crackdown-on-afghan-migrants-2016-2, 9/1/2017

European Economic and Social Committee (2016). Mission Report - Croatia. http:// www.eesc.europa.eu/resources/docs/croatia_migration-mission-report_en.pdf Hardman, R. (2015). The longest walk to the promised land: ROBERT HARDMAN witnesses the frenzied attempts of thousands of refugees as they march from Hungary to Austria. The Daily Mail, 4 September.

Huntington, S. (1989). No Exit - The Errors of Endism. The National Interest, Fall 1989 , pp. 3-11.

International Organization for Migration, UK (2015). Strategic Plan 2016-2020. London: IOM, UK. 
Kasnota, A. (2016). Solving the refugee crisis in Europe: Can visegrad group ( $\left.\mathrm{V}_{4}\right)$ provide an effective alternative to Angela Merkel's 'Open Door' policy on migrants? Forbes, 15 September.

Kibria, N. (2011). Muslims in Motion: Islam and National identity in the Bangladeshi Diaspora. New Brunswick, NJ: Rutgers University Press.

Kuko, S. (2006). Proširena Europska unija - regionalna ili globalna sila? Split: Europski pokret.

Marian, J. (2016). Map of most common country of origin of foreign born population. The Jakub Marian webpage. https://jakubmarian.com

Mead, W.R. (2014). The return of geopolitics. The revenge of the revisionist powers. Foreign Affairs, May/June 2014. https://www.foreignaffairs.com/articles/ china/2014-04-17/return-geopolitics

Migration Watch, UK (2017). A summary history of immigration to Britain. https:// www.migrationwatchuk.org/briefing-paper/48

Migreurop Project (2012). The encampment map Migreurop officialwebsite. Available at http://www.migreurop.org

No Border Initiative Zagreb (2016). Report, 11 November. http://attack.hr/ izvjestaj-inicijative-noborder-hrvatska/

Paasi, A. (1998). Boundaries as social processes: Territoriality in the world of flows. Geopolitics, 3(1), pp. 69-88.

Patković, N. (2015). Zbogom, Opatovac, vrijednih Sirijaca uvijek ćemo se sjećati. Jutarnji list online, 8 November.

Pavlić, V. (2016). EU extends deadline for Croatia to use money from Schengen facility. The Total Croatia News online, 29 July.

Rahman, M. and Kabir, A. (2012). Moving to Europe: Bangladeshi migration to Italy. ISAS Working Papers 142. https://www.files.ethz.ch/isn/137192/ ISAS_Working_Paper_142_-_email_-_Moving_to_Europe_-_Bangladesh_Migration_to_Italy_07022012143721.pdf

Rienzo, C. and Vargas-Silva, C. (2015). Migrants in the UK: An overview. Migration Observatory Briefing. University of Oxford. http://www.migrationobservatory. ox.ac.uk/wp-content/uploads/2017/o2/Briefing-Migrants_UK_Overview.pdf

Thachuk, K. (ed.) (2007). Transnational Threats. Smuggling and Trafficking in Arms, Drugs and Human Live. Westport, Connecticut/London: Praeger Security International.

United States. Drug Enforcement Administration. Strategic Intelligence Division (1995). The Balkan Route. US. Department of Justice, https://www.justice.gov

Von Rohr, D. and Delaney, R. (2016). Italy's second economy: The impact of Bangladeshi migration. Inter Press Service News Agency. ${ }_{5}$ September. http://www.ipsnews. net/2016/og/italys-second-economy-the-impact-of-bangladeshi-migration/ 
Zorko, M. (2015). The construction of socio-spatial identities alongside the Schengen border: Bordering and border-crossing processes in the Croatia-Slovenia borderlands. In: C. Brambilla, J. Laine, J. Scott, and G. Bocchi, eds., Borderscaping: Imaginations and Practices of Border Making. London: Ashgate, pp. 97-110.

\section{About the Author}

Marta Zorko works as an Assistant Professor at the University of Zagreb in the Faculty of Political Science, Department of International Relations and Security Studies. Currently she holds the position of Vice-Dean for academic and student affairs. She holds a Ph.D. in the area of Border Studies and teaches in the area of Political Geography and Geopolitics, Security, and Peace Studies. 



\section{Section III}

Representations of Borders and Mobility

in Diaspora 



\title{
9 The Borders of Integration
}

\author{
Paperwork between Bangladesh and Belgium
}

\author{
Malini Sur and Masja van Meeteren
}

Jones, Reece and Ferdoush, Md. Azmeary (eds), Borders and Mobility in South Asia and Beyond. Amsterdam: Amsterdam University Press, 2018 DOI: 10.5117/9789462984547/CHo9

\begin{abstract}
This chapter draws on the experience of Bangladeshi men in Belgium to argue that integration should be conceptualized not as the outcome of ideal-type national models of citizenship and integration, but as the product of the intersection of migrant aspirations and strategies with regulatory frameworks. It argues that a comprehensive engagement with identity theft and new forms of paperwork that straddles South Asia and Europe offers insights into what integration entails, and how it materializes through everyday practices and dilemmas. The struggles for paper documents and processes that establish the paper identities and civic participation that are foundational to integration provokes us to rethink what such processes and policies entail. In other words, integration is also about the struggle to integrate. Such struggles include troubled border-crossings and anxious arrivals, and moral claim-making, civic participation, and collective protests in the re-settled context. The chapter suggests that the everyday aspirations and prolonged disappointments of people in resettled contexts are foundational to comprehending what integration implies. The processes and dilemmas that enable and disable people to integrate in Europe rely on 'paperwork'.
\end{abstract}

Keywords: citizenship, belonging, undocumented migration, civic participation, deservingness

In the twenty-first century, undocumented border-crossings have made historical anxieties surrounding nations and citizenship resurface. They have also generated new humanitarian dilemmas. While contemporary humanitarian efforts resonate with old nationalist agendas in ways that reinforce the distinctions between refugees and migrants - fixing the former 
in narratives of persecution and needing asylum, and the latter in rational economic choices -, the precarious circumstances in which people continue to be displaced and move across borders make these categories porous. Given the diversity of contemporary displacement and resettlement, Nicholas De Genova's reminder that the study of undocumented migration has been lost in the struggles between demography, policy studies, and criminology holds true. In showing how undocumented migrants do not live in isolation, but in proximity to and engaged with citizens and documented migrants, De Genova illuminates the intellectual paucity of migration studies. He compellingly argues that such investigations on international migration seldom treat the migrant as a subject of ethnographic enquiry, and instead remain content to frame migrants as either 'illegal' or 'immigrants' (De Genova 2002). His observations hold true for the large numbers who are fleeing western Asia's war ravaged zones, along with those from regions like South Asia who have been displaced for other reasons, and who seek asylum in Europe.

Indeed, the questions that contemporary migration scholars encounter are more daunting than those of a century ago, when investigations primarily focused on migration from Europe to North America (Lee et al 2014). As Richard Alba and Nancy Foner have recently cautioned, all wealthy western societies will be undergoing transitions toward increasing diversity in the coming decades. They advance that, due to massive demographic changes that are largely fuelled by migration, rich nations will increasingly rely on young non-natives and minorities to thrive economically, socially, and culturally. Therefore, they argue that successful integration is central to ensuring that migrants are not marginalized into becoming disadvantaged minorities (Alba and Foner 2014).

In the light of the contemporary humanitarian crisis in Europe, and its implications for those who were already seeking asylum in Europe, this chapter explores the relationships between undocumented migration and Europe's integration policies. We argue that ethnographic attention to the everyday predicaments of asylum seekers in Antwerp, a city in the Flemishmajority area of Flanders in Belgium, and the accompanying collective actions, offer new ways of thinking about resettlement and belonging. We especially followed migrant lives in the context of a wide-raging regularization campaign that aimed at integrating undocumented migrants in Belgium. In particular, we consider the challenges that Bangladeshi asylum seekers face in Belgium, their struggles to procure new documents and their efforts to convince a distant world of their capability and worthiness of civic participation and residency. 
The visibility of undocumented Bangladeshis living in Antwerp who marched in Brussels on 17 June 2006 with more than fifteen thousand protestors to the beat of drums and chants, holding placards demanding regularization, assumes greater political significance today as states violently police undocumented border-crossings (Sur 2014; Kalir, Sur and Van Schendel 2012). On that day, as the protestors marched, music blared from a small van with oversized speakers. Families gathered on their balconies to get a glimpse of the large procession. Having arrived in Belgium from various parts of the world, the protesters were mensen zonder papieren ('people without papers') - commonly portrayed as 'illegal' migrants. This demonstration in Brussels was the grand finale to a regularization campaign initiated in December 2005 by NGOs in Belgium, such as the Progressive Council for People without Papers. The Progressive Council argued that since these people had lived in Belgium for several years, embedding themselves within Belgian society and acquiring language skills, they deserved rights as residents and workers under the clauses of integration promoted by the Belgian state.

This collective protest, the demands of Bangladeshi asylum seekers and their Belgian supporters, provide a useful starting point to ethnographically probe the efforts of mensen zonder papieren to integrate in Belgium. Adrian Favell and Gary Freeman argue that integration should be conceptualized not as the outcome of ideal-type national models of citizenship, but as the product of the intersection of migrant aspirations and strategies with regulatory frameworks (Favell 2010; Freeman 2004). In ethnographically exploring the struggles that surround integration, we suggest that not only macro demographic demands, but also the uncertain circumstances under which people move and are compelled to make a living, make questions of integration critical to the social sciences. We contend that the events that structure integration as a means to enable inclusions within Belgian society, and the everyday uncertainties of Bangladeshis who sought to resettle in Belgium, foreground both the efforts and the dilemmas that surround it. We posit that integration is also about the struggle to integrate. Such struggles include troubled border-crossings and anxious arrivals, moral claim making, civic participation, and collective protests in a resettled context. We argue that the prolonged disappointments and everyday anxieties of people in relocated contexts are foundational to comprehending what integration implies. The processes that establish paper identities and civic participation which are therefore foundational to integration - invite us to rethink what integration actually entails.

The processes that facilitate and impede people's integration in Europe rely on what we call 'paperwork'. In what follows, we ethnographically and comprehensively engage with identity theft and new forms of paperwork 
that straddle Bangladesh and Belgium. From 2006 until 2011, we conducted participant observation and interviewed Bangladeshis who were at various stages of asylum appeals, as well as those who had stayed on in Belgium after their request for asylum had been rejected. Unlike the asylum seekers from Africa and Latin America, undocumented Bangladeshis were all men. ${ }^{1}$ Their specific predicament as men and Muslims demonstrate how gendered and religious identities reinforce racial stereotypes that cast Muslim men as criminals. Since the presence of foreigners in Europe (both with and without documentation) is at the centre of contemporary debates on citizenship, the lives of Bangladeshis in Antwerp offer valuable lessons into the everyday enactments of integration policies, their potentials, and pitfalls.

\section{Paperless Lives in Belgium}

Following the Second World War and through the 1950s, the presence of foreign workers recruited through guest-worker policies and from former colonies transformed Europe's social landscape. By the 1970s, family reunification schemes ensured that this foreign work force established communities with strong institutional bases and political aspirations. The presence of foreign workers widened the political horizons of citizenship from being uniquely and singularly premised on shared nationhood to alternative emancipatory interpretations, such as post-national citizenship. Yasemin Soysal makes a compelling argument that post-national citizenship occurs when the logic of universal personhood replaces nationhood and universal human rights replace national rights. However, she also acknowledges that there is a dialectical tension between national citizenship and universal human rights, where the nation-state continues to act as the primary mediator and guarantor of both types of rights (Soysal 1994).

The consequences of this tension between national citizenship and universal human rights are evident in Belgium. Belgium was one of the main migrant-receiving countries in the post-war period (Moch 2003). Workers from Southern Europe, Northern Africa, and Turkey could travel freely to Belgium and formalize their stay after they had started to work (Martiniello and Rea 2003). These migrants were considered welcome 'guests', as Belgium needed them to alleviate labour shortages. A decade of economic prosperity followed, during which migrants settled in urban conglomerations. The host population perceived them as docile and honest (Martiniello 2003). However, 
when labour shortages decreased due to the economic downturn in the 1970s, migration policies became more restrictive, and efforts were increasingly made to prevent migration (Martiniello 2003). The economic crisis of the $1970 \mathrm{~s}$ negatively impacted Bangladeshis in Europe. Like other migrants who did not have relevant educational skills, they were unable to look for alternative employment. The rising numbers of immigrants on welfare benefits set a new negative tone to public opinion on immigration, in which non-European immigrants were seen as depleting the welfare state. Bangladeshi migrants sought asylum after the end of labour recruitment in 1973 and continued to legally arrive in Western Europe to work in the 1980s (Knights and King 1998).

In Belgium, however, other forms of migration persisted even after guest workers were no longer being recruited: in the 1980 s, family reunification was on the rise, and since the beginning of the 1990s, a growing number of asylum seekers have arrived (van Meeteren, van San, \& Engbersen 2008). At the end of the 199os, irregular migrants occupied churches and went on hunger strikes to demand regularization. As a response, the Belgian federal state instituted a regularization campaign in 2000 as an attempt to end the marginalization of migrants without documents. The number of asylum applications submitted as part of this campaign was 42,691 - the highest ever recorded in Belgium. There were several grounds on which migrants could be regularized, including special ties to Belgium or Belgians - commonly interpreted as 'integration' (COM 2004). In practice, this meant that applicants would try to prove their special ties by adding all kinds of paperwork to their application. This paperwork, for example, would include letters from Belgian citizens who acknowledged their friendship with the applicant, or from Belgian children who stated that they were friends of the applicant's children. Proof of school enrolment and membership in social organizations were other criteria for integration. Undocumented residents frequently invoked these and supplied papers in their regularization applications.

After this round of regularization in 2000, Belgium escalated border controls for irregular migrants while making it easier for regular migrants to obtain Belgian nationality. This marked the beginning of new Belgian immigration policies based on the twin pillars of stringent rules about immigration and asylum aimed at newcomers, and an integration policy for older migrants who were already present in the country. Over a period of time, the integration framework expanded to, perhaps unintentionally, also to include services for people without papers.

Although illegal entry and stay is considered a criminal offense punishable by a fine and/or detention of up to three months under Belgian law, Belgian authorities detain to deport, rather than imprison, irregular migrants 
(van Meeteren, van San, \& Engbersen 2008). Furthermore, the police do not deport individuals who have on-going regularization applications (van Meeteren 2014). One way of legalizing an irregular status is to apply for regularization under 'exceptional circumstances'. The criteria for these special circumstances are unspecified. We observed that people made efforts to learn the native language, procured letters from citizens they know well, placed their children in school, and had long lengths of stay. Each of these factors was sometimes considered exceptional for regularization. However, the chances of regularization are invariably slim - only about 300 people per year are granted regularization based on exceptional circumstances (van Meeteren, van San, \& Engbersen 2008). Most lawyers and NGO activists who give legal advice recommend that irregular migrants claim integration as a ground for regularization. Although unspecified by the law, the organizations that interact with irregular migrants argue that integration is a valid criterion. Since 'integration' is not a clear-cut concept and can be interpreted in different ways, these applications are, in legal terms, trial-and-error exercises. Many irregular migrants try, and some try more than once. On average, 15,00o irregular migrants apply for regularization in Belgium each year (van Meeteren, van San, \& Engbersen 2008). Since the possibilities for individual regularization are limited and uncertain, often the only chance of legalization is through general and collective campaigns.

Throughout 2006, Bangladeshis and others occupied churches, demonstrated in the streets, and engaged in hunger strikes all over Belgium. These actions began in response to a series of events in 2005, when a group of 130 irregular migrants occupied a church in a district of Brussels. After a prolonged hunger strike, the Minister of Internal Affairs conceded to their demand for residency, which in turn sparked similar actions all over the country. The UDEP (Union pour la Défense des Sans-Papiers) a collective of irregular migrants organized these. With the support of several NGOs and semi-governmental organizations, the 'pro-regularization movement' managed to influence government debates about the reform of asylum procedures. Further, it managed to get the government to formalize some of the criteria for individual regularization that had been used informally since the previous collective regularization. For example, the criterion used during the campaign in 2000 that migrants who had been enrolled in asylum procedures for an unusually long period of time would be granted regularization, now became formal policy. However, migrants who have been involved in crimes, served jail sentences, or caught using false identity papers or providing a false name are denied regularization (van Meeteren, van San, \& Engbersen 2008). 


\section{Papers and Lives}

The contemporary migration of Bangladeshis to most European countries reflects recent migration pathways between countries that have little historical association. This is symptomatic of the new globalization of the migration process, which sees ethnic communities establishing themselves with enormous rapidity in different parts of the world (Knights 1996). Upon their arrival in Belgium, Bangladeshis and other undocumented people become subject to state scrutiny. This is not only because they are compelled to use the services of migration agents and brokers for travelling but also as they arrive without documentation. Belgium has responded to the presence of undocumented people with a combination of regularization measures that depend on a pre-determined set of conditions and punitive responses, including deportations. Like other mensen zonder papieren, those Bangladeshis we followed during the regularization campaign and after, were quick to realize that they were not welcome in Belgium. Moreover, being Muslim men, their religion and gender further marginalized them. For Belgians, Bangladesh is internationally discredited as an example of high corruption and is considered part of the Islamic terror frontier. In addition to race, Islam and crime are seen as representative of the migrant threats that haunt Western Europe. Because of these public perceptions, Bangladeshis in Antwerp conveyed that Belgians aligned them with Turkish and Moroccan migrants with whom they have no historical or cultural links, except for supposed connections to crime, delinquency, and shared religious beliefs. However, their legal status and predicaments in Belgium are vastly different from these earlier settlers.

With the exception of Minaz and Karim, who had been residing in Europe for over twenty years, most of the Bangladeshi men we spoke with had been completely clueless about their final destination in Europe when they left their villages in Bangladesh. They travelled cramped in the bellies of cargo ships, and partly by roads, navigating complicated routes, aided by migration brokers who guided them to Europe. These brokers, commonly referred to as 'visa dalals', manage the business of the 'European dream' an illustration of what David Kyle and Christina Siracusa designate a 'migrant-exporting scheme' (Kyle \& Siracusa 2005). In most instances, the brokers emphasized wage differentials between Bangladesh and European countries as the selling point, concealed legal requirements and differences in actual costs of living. Visa dalals in Chittagong, Dhaka, Mumbai, and Dubai swiftly dispatched them to Europe. Spanning airports and seaports were other collaborators - customs officers, immigration services, and navigators 
who let them pass with false names and forged documents. Occasionally, brokers coached them to assume false identities that they could convey to the immigration authorities. After arrival in Europe, there were sympathizers who had arrived earlier under similar circumstances and provided shelter, employers who hired them for below-minimum wages, 'co-illegals' who supplied information, migrant support organizations, and lawyers who aided them to make appeals for asylum. In several instances, women in Belgium offered to marry Bangladeshi men for a high fee, to enable to prove that they had emotional connections to the country. Each industry had cashed in on the basic aspirations for stable resettlement. Like state agents in Bangladesh, ones in Belgium too, ignored, restricted, regulated, and in several instances, supported these acts.

While for some Bangladeshis who were part of the public call for a regularization campaign in 2006, Belgium was the first port of entry; others had been circulating through Europe for anything between seven and 25 years. Bangladeshis in Belgium found themselves aligned with second-generation Muslim migrants who Belgians equated with asylum seekers, and regard as riding on the benefits of the welfare state. In contrast with 'post-national' guest workers and their descendants, mensen zonder papieren are uniquely located at what we designate a territorial paradox. It is especially important to acknowledge this category today, with the massive border fortification programs that European nation states are undertaking to prevent refugee movements in the light of recent air strikes and wars in western Asia. War and devastation across western Asia along with migration brokerage are likely to ensure the persistence of mensen zonder papieren as a category that oscillates between the clear-cut definitions of refugees and migrants.

Bangladeshis in Belgium are simultaneously situated within a territorial vacuum and intensely shaped by territoriality. Paperwork that includes the loss of original passports and identity papers confiscated by migration agents and the quest for new documents underscores this territorial tension. Both people displaced by wars and those depending on predatory migration brokers fall outside the labour regulatory structures of labour-sending and receiving nation-states. In the absence of a sending nation-state and documentation that espouses nationality and labour connections, mensen zonder papieren also contrast sharply with former guest workers who have resettled in Europe. Upon their arrival in Europe, such unauthorized migrants are entirely dependent upon border-patrol agents, humanitarian agencies, the regulatory framework of the nation-state they manage to get a foothold in and others who share similar predicaments. 
Mannan, who left Chittagong in 1998, was unaware of the papers he needed to travel to Europe. For him, paperwork - or the actual implications of having a paper document - started in Dubai when his broker confiscated his passport. Mannan who had newly acquired this, could barely relate to it as an identification document. Upon his arrival in transit destinations such as Dubai and Morocco, unknown brokers controlled his movements. These brokers destroyed his passport and other identity papers, and they compelled Mannan and other travellers to camp for months in concealed places while they secretly arranged routes of travel to Europe. During his confinement in one such secret camp in Dubai, Mannan stayed with a group of Indians and Pakistanis for a month. After this, the broker arranged their travel in batches to mitigate the risks of being associated with illegal entries. Some were made to travel via Eastern Europe, and some via Morocco. Mannan told us that the final group of 41 South Asians left for Turkey a few days after him, but had never arrived in Europe; all of them had died from their injuries after their truck overturned.

Karim purchased a fake United Arab Emirates passport for 4000 euros, obtained by selling his only plot of land in Feni district in Bangladesh. From Dubai, a broker arranged his place as a crewmember in a cargo ship with seven Indians and Pakistanis. He was supposed to load sugar and sail to Jordan, but he jumped ship in May 2002. He left his false passport in the cargo ship at the Antwerp harbour. He had no idea about Europe; he was only acquainted with stories of England, where his brother had lived for over twenty years. Upon his arrival in Antwerp, Karim walked through the streets and found a shop owned by a Bangladeshi who advised him to destroy his passport. He was sheltered there for twelve days, too scared to venture outside. During this time, he wrote his first asylum appeal and travelled to Brussels to register his fingerprints with the immigration office. Having no recourse to legal employment, Karim submitted a request for asylum on the grounds of political persecution (coinciding with political upheavals in Bangladesh).

The Belgian state places Karim and Mannan in the category of 'bogus asylum seekers', 'rejected asylum seekers', and those whose asylum pleadings are in various stages of consideration. With no passports, they continued to inhabit the grey zone between asylum and criminality, living through several appeals and judgements for more than ten years. At the first stage of asylum, when their claims were being considered, they were given a white identification card, which entitled them to receive social welfare. If their asylum hearing ends on a positive note, they would receive an orange card. This confers on them the right to work. For those who held orange cards, the 
aspiration was what they called a plastic card - a residence permit, which allowed them to travel back and forth to their country of origin. Finally, many dreamt of a red passport, which would confer on them Belgian nationality, marking their entry into Belgian citizenship. In this way, state systems of registration that includes graded identity cards, embrace citizens and bring them under state surveillance and control (Torpey 2000). Only after landing in Europe did Mannan and Karim realize the enormous importance of having new papers - through repeated asylum pleadings, visits to asylum lawyers, and appeals for regularization. For four years, their inconsistent testimonies had made their asylum claims weak, judges had rejected their appeals and struck them off social welfare. When we met them they were always agitated, pensive - awaiting regularization.

Tanveer, who managed a telecommunication shop, was not as perturbed about his irregular status, unlike Karim and Mannan. Speaking to us over the faint tune of Bollywood music while he cheerfully managed irate customers complaining about faulty connections, he conveyed that he had resigned himself to a life of uncertainty. A highly reluctant migrant, Tanveer's father had cajoled him to enroll in a management course at the University of Paris in 1993. In Tanveer's self-depiction, he aligned himself with people from his district, Bogra, whom he argued were exceptions to footloose Bangladeshis. To substantiate this claim, he stated that in the past years he had not met anyone from his district anywhere in Europe: 'Even gnawing poverty does not push us to leave our hometown; we would rather sell betel leaves on the streets than leave'. Within six months of his arrival in Paris, Tanveer's father died, causing the flow of funds that Tanveer relied on to dry up. Without completing his management course, he tried to find work in Paris and failed. Acquaintances asked him to apply for asylum. He sought asylum as an activist victimized due to his political beliefs and was rejected. Within the next two years, he moved to Cyprus and then Belgium.

When Tanveer's asylum appeal had reached its final stages in Brussels, however, he distanced himself from his own testimony. To the complete disbelief of his asylum lawyer, he informed the judge that he was repulsed by Bangladeshi politics as a student, had no political affiliations, and was neither a persecuted Awami League activist nor a Bihari refugee from Bogra, as his asylum papers had stated. He informed the court of his difficulties in being a student without funding, being away from Bangladesh for over a decade, and not acquiring any skills that would help him to gain employment in Bangladesh if he were to go back. Tanveer pleaded for support. The judge - although sympathetic and touched by his frank testimony - responded that he did not 'fit' into any schemes for support in Belgium, which were 
limited to asylum claims. Since then, Tanveer has stayed on in Antwerp, managing a telecommunication shop for a Pakistani employer. His ambiguous predicament shows the limitations of integration policies that assume people can only arrive in Europe as victims of fear and persecution as well as disregard how circumstances compel legal immigrants like students to become irregular.

\section{The Right to Reside}

Whether mensen zonder papieren like Tanveer, Karim, and Mannan will get the rights to residence and work in Belgium is decided by a combination of factors: the Belgian state and its asylum, integration, and regularization policies; the Bangladeshi state, its international rankings for democracy, corruption, fundamentalism; facts and figures that match crisis databases; and, finally, the oppositional discourses of Islamophobia and pro-migrant solidarities in Western Europe. Additionally, mensen zonder papieren are juxtaposed between the politics of the pan-European multiculturalism with which Belgium aligns - and discourses on integration, which speak to sub-nationalism in Flanders. They benefit, for instance, from an asylum framework that is guided by humanitarian agendas and international covenants such as the 1951 United Nations Convention relating to the Status of Refugees. Outside the asylum system, some of their human rights are guaranteed by civil society organizations. Integration policies in the Belgian federation are organized along linguistic divisions (communities): Dutch, French, and German. Brussels, where all three languages are accommodated, has its own integration policy. Flemish integration policies have persistently emphasized the ability to master the Dutch language, amongst other criteria (Bulcaen \& Jaspers 1999, cited in Coffé \& Tirions 2004, 34). This is an expression of Flemish sub-nationalism, which emphasizes that the language (historically) spoken in the region should be spoken by all residents of the region, in order to constitute a collective identity group (Coffé \& Tirions 2004). The Flemish sub-nationalist consciousness started to grow in the early 1990s after the electoral gains of the extreme-right Vlaams Blok (later known as Vlaams Belang), and has remained high ever since (Billiet, Coffé, \& Maddens 2005).

Mensen zonder papieren from Bangladesh feel that they are rejected by the Belgian state, which denies them residency and permission to work, and by Belgian society, which treats them as unwanted aliens. This perception of un-wantedness is reinforced by anti-immigrant politics, which are not 
only aimed at undocumented migrants but also at former guest workers, their children, and those who have been granted asylum. This is especially so in the cities in the Flanders, where Vlaams Belang's has obtained massive electoral victories over the past fifteen years. For instance, in local elections in October 2006, almost a third of Antwerp's inhabitants voted for this party, whose rallying cry was to 'put our own people first', weed out criminals among migrants, and get all migrants to integrate into the Flemish subnational culture. The mainstream parties initially agreed that they would not form a coalition with Vlaams Belang because of this anti-immigrant discourse. Although the parties have stuck with this agreement, however, there has been a convergence in the immigration discourse over the years; several mainstream parties now echo the views of the extreme-right wing, albeit in softer tones (Billiet, Coffé, \& Maddens 2005).

Armed with a degree in Chemistry from Jagganath College in Dhaka, and organizational skills gained as the head of the Flemish Bengali Association (FBA) - an association of Bangladeshis - Warsi argued that Europe has failed to understand the human conditions that persuaded him and others to cross several difficult and violent borders. He felt that the ground rules for humanitarian concerns should be rooted in the human condition. Hunger and death should determine the causes that deserve shelter and social support - whether these are fuelled by war or poverty should be immaterial. But the European framework fails to understand that the basic human condition is death - and the specific events that trigger it should not influence asylum policies. The system should not, therefore, privilege war over famine or economic crisis. He justified his presence in Belgium as a response to the political crimes perpetrated by developed countries upon nations like Bangladesh after depleting their resources.

Warsi never failed to remind us that he did not work because he wanted to be on the 'side of the law'. He denied that his entry was 'outside' the law; his carefully crafted story of religious persecution as a Ahmadiyya minority explained and justified his presence in Belgium. Warsi felt that illegality was essentially a western condition that was used as a tool when countries wanted to close their borders. He referred to a circular issued by the Belgian state in 2005 directing its nationals not to travel to Bangladesh as tourists for security reasons. The same country, he declared, turned away asylum seekers from Bangladesh without any remorse! Unike Warsi, Shahidul proactively sought employment since he needed to remit money home for his family. Once, he was caught by the police in a shop where he was working in the back. The police asked him to leave the country within five days. However, like Warsi, he argued that since he was not a criminal, he would not leave 
the country. He produced his asylum papers. He stated that: "I knew and they knew that formally, since I did not have work permit, it was illegal to work. But that did not make me into a criminal, did it?"

Influenced by Warsi's leadership, several Bangladeshis in Belgium awaiting hearings for their asylum appeals reiterated his political views. Shahidul explained his presence as circumstantial and nothing more. But no one, he claimed, had made any attempt to know either the circumstances which compelled his displacement as an unemployed youth from Bangladesh or even his current precarious existence in Antwerp as a person who did not belong here. He hated participating in the charity dinners organized by their Belgian supporters, and was acutely conscious of being declassed. He compared these dinners to the kangali bhojon in Bangladesh, where affluent and charitable Bangladeshis distribute free food to the poor.

Jeroen, a Belgian official who works for the Ministry of Integration in Antwerp, emphasized the state's official position on irregular migrants. He lamented the large presence of 'adventure cowboys' who snatched rights away from genuine asylum seekers. He further argued that, as a city, Antwerp displayed a complete lack of political courage and was unable to deal with migrants without papers. Although he was closely involved with regularization campaigns as a part of his official duties, he remained sharply critical. He found the campaign idealistic and estranged from reality: "They believe very much in the vision that those people should have the right to stay here, while the starting point should always be that we should investigate whether these people do in fact have the right to reside here', he remarked in indignation. He attributed the primary cause of migration to economics, aided by courage and financial capacity. "This is in fact a perverse system that causes the real political refugee to have less and less chances to come here, and the courageous, the cowboys [...] people from Africa, Asia, South America, those cowboys, they come here.' He bitterly recalled from a recent church asylum visit that none of the migrants could even speak Dutch - the opposite of the image promoted by activists that such migrants are linguistically integrated. He predicted that Belgium's immigration system would collapse if migrants were to be regularized. Instead, he argued that the system should reject un-integrated migrants, saying, 'Sorry but you are not integrated, you have been here for six years, and you do not speak even five words of Dutch, wouldn't you start thinking of going back?' He advanced that a high premium should be placed on return migration, rather than resettling migrants in Antwerp. The everyday complexities that surrounded migrant belonging defied Jeroen's precise thresholds of inclusion and exclusion. 


\section{Protests and Participation}

The main problem is that they present us as illiterates - and criminals. They think we are thieves - there are enough working class white people who will even steal bicycles, but we will always be tainted as thieves. Shahidul, 14 May 2006

Bangladeshi men had camped in Antwerp's churches in 2006 with other migrants from all over the world. While city residents and Belgian citizens, including asylum activists, journalists, and pastors, arrived in the churches to support the campaign, outside them, right-wing groups like Vlaams Belang held press conferences opposing the campaign.

Warsi was at home in a small protestant church in Antwerp. Over endless sexist Bollywood jokes, he brewed coffee, gargling once with it before speaking into our tape recorder. Even though his numerous appeals for political asylum had been rejected, Warsi was not a dejected man. He marched along with the others and sought out journalists as the head of the FBA - a registered organization of Bangladeshis without papers funded by the Flemish community. Marijke, a Belgian national in her early sixties, is the most vocal Belgian supporter of this organization, which mostly functions out of her house and the blue spiral file that Warsi keeps close at hand. The FBA was started in 2004, when Marijke's friend who was working with integration services suggested that Warsi should organize the Bangladeshis in Antwerp to integrate them into Belgian society. In the past, Marijke had supported migrants without papers by sheltering and providing for them in her house. Warsi has been residing with her for the past seven years; during this time, they wrote several appeals for regularization that have all been denied. When we interviewed her, Marijke was glad that the regularization campaign was in full swing - and that Warsi was pre-occupied, not sitting at home and clumsily helping her with household chores. Warsi occasionally dipped into the bulky blue file as he spoke to us. Sometimes he pulled out documents that were filed in a random order and encased in polythene sheets. Warsi always kept the file next to his mattress in the church. In a separate green folder, he kept a list of his several private petitions seeking a regular residency status in Belgium.

The Belgian state dealt with Warsi and his associates in several ways: rejecting their numerous asylum appeals, sheltering them through its civil society network (mostly with government funding), and finally, doling out funds to the FBA through the Ministry of Integration for the hosting of cultural events. The state therefore extended a helping hand to migrants who could not be deported for reasons like not having passports, while 
simultaneously labelling them as illegal. When FBA was founded, Warsi who conveyed that he had been living a life of self-imposed seclusion from his fellow Bangladeshis in Antwerp for reasons he did not elaborate - called upon Zakhir, whom he had befriended at a camp run by the Red Cross. Within days, Zakhir spread the word through visits to the shops and telecommunication centres where Bangladeshis mostly worked. Bangladeshis with citizenship and residency rights distanced themselves and chose to stay away from FBA's activities as the latter comprised of undocumented Bangladeshis. The first few gatherings were self-funded by FBA's 54 members, and the Flemish community, i.e., the local government, funded subsequent events.

In one of the cultural events organized by the FBA and funded by the Ministry of Integration, Warsi hosted a two-hour cultural show addressing an audience of Bengalis with a scattering of Belgians, reading aloud from written notes. Between songs, dances, and a documentary on Bangladesh, Warsi made numerous announcements of the regularization procedures in various European countries. Although in the audience at this event were several Bangladeshis who had settled in Belgium, but did not align with the FBA. They were members of a Bengali Association that is comprised entirely of people who had acquired legal rights of residence. They often employ their paperless co-nationals, but maintain social distance. The FBA members criticized the organizational politics of the main Bengali Association, which, according to them, reflects matobbori ('feudal politics') - replicating the patronage and corruption widely prevalent in Bangladesh. The members of the FBA complained that the Bengali Association imbibes nothing from the uncorrupted climate of Belgium; instead, they replicate all that is politically decadent about Bangladesh.

For Warsi, this forum, which defines his existence in Belgium, does not just orient Bengali people in Belgian society, but also more forcefully conveys information to Belgians about Bangladesh. When Bangladeshis find themselves in a country like Belgium where they have no historical links, they are faced with a people who are ill equipped to understand them. They perceive themselves to be lumped together with other migrants and seen as making an illegal living by flooding the streets of Belgium.

Back at the protest, Warsi passionately spoke to news-hungry journalists about how Europe needs to redeem its colonial past. Natives, he argued, had embraced colonizers with civility. This was not reciprocated for migrants who arrived at the doorstep of Europe. The journalists reporting on the asylum demands in the sleepy city of Antwerp lapped up his words and reproduced them almost verbatim the next day.

On 27 June 2006, we helped Warsi, Mannan, and others shift from one church to another. While we walked in a large procession on the street, 
the police kept watch to ensure that we did not disrupt the thin traffic on the roads of Antwerp. Warsi spoke to the police who were monitoring the procession, assuring them that Bangladeshis were not lawbreakers and criminals. We silently walked alongside, the drizzle slowly washing away the paint from our banners. Rofique, another member of the FBA who was initially disinclined to speak to us muttered that he had travelled enough from Iran to Russia, after starting out in Mumbai. Now he was fed up. He grumbled that he was suffering from monetary losses after paying 1500 euros to a Belgian national for pretending to be his partner. "The bitch did not tell me that they would come to inspect our bedroom, nor did she even warn me that I would need to pretend to live with her, no! My money is all gone now.' His angry narrations called attention to the heavy monetary losses that he had suffered not only during his multiple journeys but also in Belgium.

We unloaded mattresses from vans and lined them up in their new destination, and then walked into the new church. At the door, a few men dressed in smart grey suits and representing the Vlaams Belang chanted slogans against illegal migrants and blocked our access to the church temporarily. The journalists who had been following our procession, and who had interviewed Warsi now scurried forward to record footage. The opinion of politicians, especially ones that were anti-migration, that journalists reported fed into prior public biases. We waited for the small group to disperse before accessing the church premises. Close to the altar, a makeshift podium had been created for the speakers. A group of Congolese drummers broke into thundering beats before the speeches began. The pastor spoke to his audience of mensen zonder papieren and activists. A kindergarten teacher pleaded on behalf of her Belgian six-year-olds who would miss their classmates if their parents were deported for not having papers. From the audience, Warsi snatched the two-year-old Shamima from her father Mannan and marched up to the podium reserved for speakers. Shamima's presence in his arms made Warsi look human. Shamima seemed momentarily taken aback by the attention, but recovered soon enough to clap her hands in glee and smile at a kindergarten teacher who sat in the audience. Cameras flashed once again. Warsi took out a somewhat crumpled poster from his inner jacket, and flashed it to the packed church. It read 'Shamima, our girl zonder papieren turns two today'. At the sight of a child, and the accompanying banner, the audience broke into loud applause and the drummers thundered once again. The noise slowly died down and the speeches concluded. Shamima jumped from Warsi's arms to Marijke as we walked to a large kitchen room where benches had been lined against the wall. 
Mannan, who was trained as a cook had worked for two days to prepare meals for everyone involved in the regularization campaign to celebrate his daughter's second birthday. He heaped generous spoonfuls of food onto paper plates, which we passed on as people streamed into the kitchen and filled up benches. Shamima stood somewhat agitated in a corner, as her Indonesian Muslim friends had decided not to attend the dinner since it was held in a church. Despite the marital frictions that this dinner had created, more than 20 Bangladeshi men had gathered that evening to support the cause of regularization. Their faces bore signs of exhaustion from working all day in grocery stores and supermarkets; others left soon after dinner for shifts in night shops. They heaped a table with brightly wrapped presents. Marijke gently held Shamima and sliced a huge cherry cake as we applauded.

Events like this that demonstrated Bangladeshi hospitality and generosity, as well as the FBA, provided Bangladeshi men with an avenue to distance themselves from the criminality associated with being 'illegal' Muslim men. Most members of the FBA held that the Belgian state's funding of the organization's activities demonstrated that they had a quasi-legal existence and that their presence had state support. In other words, their presence, although unauthorized, was not completely frowned upon by the state (Van Schendel and Abraham 2005). Further, the members of the FBA steered clear of comparisons with other settled Muslims communities such as the Turks and Moroccans, who the Vlaams Belang frequently linked to delinquency and crime.

The FBA's emphasis on collective public activities was also important for paperwork: it created a sequence of documented evidence that included the participation of Flemish families. Unlike ordinarily, when their public presence was constrained, they found it relatively easy to claim public space as protestors and activists, sometimes forgoing a day's earnings in the process. Congregating for meetings, writing and reading speeches, holding specific organizational portfolios, and conducting events counters their deep sense of being completely declassed and dehumanized in an alien environment, at least to some extent. The FBA provided a space to regain class status, to feel linked with their co-nationals, and to hold on to notions of belonging even in the absence of national passports. Protracted uncertainties about their status and residency compelled Mannan and others to be inventive, taking every possible chance to establish a sequence of events that would help organize their papers, even if this involved exploiting the image of innocence provided by their own children.

Flemish constructions of good citizenship have occasionally extended to 'deserving' and 'integrated' irregular migrants through the process of collective and individual regularizations. In their struggles for papers, 
Bangladeshis in Antwerp have emphasized their deservingness while at the same time Belgian policies have increasingly limited their opportunities and claims to gain such deservingness over time. These processes effectively make deservingness both a civic obligation and a privilege (Chauvin \& Garcés-Mascareñas 2014). On 19 November 2006, two church asylum activists were granted papers, but neither were Bangladeshi. As the church protests wound down, most of our respondents dispersed. At the same time, Vlaams Belang grew in electoral popularity. In 2009, the Belgian authorities decided to issue another general amnesty. Irregular migrants could apply for regularization based on a set of special criteria that were valid for a period of three months. During this period, irregular migrants could claim 'durable local embeddedness'. In practice, this meant that persons who had been in Belgium for five years and who could prove 'integration' could apply. It was only possible to claim 'durable local embeddedness' during these three months. About 30,000 people applied, of which only about 10,000 cases were new applications. The others were individual requests for regularization that had been shifted to the general regularization campaign (van Meeteren 2010).

\section{Conclusion}

The struggles of undocumented Bangladeshis to integrate in Belgium foreground two political conjunctures in contemporary Europe. Etienne Balibar has powerfully illuminated the first, arguing that the struggles and dealings of people without papers are privileged moments in the development of 'active citizenship'. Without this, he cautions that there is no polity, but only a 'state cut off from its own society and petrified in its own abstraction' (Balibar 2004). Read in the light of Balibar's words, the FBA and the moral and political claim making of mensen zonder papieren illuminate citizenship from below - which, as Balibar argues, combines submission to the rationality of the state with activist solidarity. For Balibar, the period of vacillation between the old forms of national sovereignty (which is not the same as the disappearance of nation-states) and the struggles of people without papers (sans papiers in France) and their defenders has made a contribution to the democratization of borders and the freedom of movement, which states tend to treat as arenas of their discretionary power. Cecilia Menjívar and Sarah Lakhani have provided another powerful interpretation of the political in the context of undocumented migration. They emphasize that state barriers and hostility towards migrants which push people towards the margins of legality also create conditions that provide the foundations for making 
'transformative, lasting changes' in people's lives (Menjívar and Lakhani 2016: 1818). These, they argue, shape integration. They further posit that in a social and legal context of increased ant-immigrant sentiment, pressures to integrate and conform may become stronger (Menjivar and Lakhani 2016).

In exploring the worlds of collective protests, organized civic participation, and the distressing everyday circumstances under which people like Mannan and Tanveer operate, we have shown how paperwork is integral to integration, and how civic participation and legalization efforts can have profound effects on the personal and social lives of asylum seekers in resettled contexts. Integration processes, then, can only be properly understood by taking both collective and individual struggles for papers and their effects into account. The efforts of the Bangladeshi protestors who were a part of the 2006 regularization campaign and whose lives represent the tightening of asylum provisions are important, as they will inform resettlement policies in Europe the coming years.

For Bangladeshi men, several of whom would have swelled the ranks of educated unemployed in Bangladesh, Antwerp is both a location that offers new possibilities as well uncertainty. In a poignant short story 'Uddin' ('The Flight') the Bangladeshi anthropologist and novelist Shahaduz Zaman illuminates the other side to this story. He describes the journey of a young cattle herdsman from a village in Bangladesh who, caught between rural poverty and urban unemployment, is mesmerized by the images of wealth and bounty hurled through satellite transmissions. Having no land to sell and buy a ticket, he clings onto the wheels of an airplane in a desperate attempt to escape despair. The clouds swirl at his feet and he slowly slips away, his body frozen and dead as the airplane lands in his dream destination. This story, and the everyday struggles of integration in Antwerp that we have emphasized, deserve scholarly attention so that the debates within the European Union that have slowly shifted from arenas of public debate and policy to crime and inter-governmental co-ordination, can once again re-think what it means to cross difficult borders (Guiraudon 2000).

\section{References}

Alba, R. and Foner, N. (2014). Comparing immigrant integration in North America and Western Europe: How much do the grand narratives tell us? International Migration Review, 48, pp. 263-293.

Balibar, E. (2004). We the People of Europe: Reflections on Transnational Citizenship. New Jersey: Princeton University Press. 
Billiet, J., Coffé, H., and Maddens, B. (2005). Een Vlaams-nationale identiteit en de houding tegenover allochtonen in een longitudinaal perspectief. Paper presented at 'Marktdag Sociologie', 2 June, Brussels.

Bulcaen, C., and Jaspers, J. (1999). NT2 voor anderstalige volwassenen - moeten/ mogen/kunnen? In: Giebens, H. (Ed.) Aardig taalvaardig, zalig meertalig: een talenboek (pp. 84-88). Antwerpen: Karel de Grote Hogeschool

Chauvin, S. and Garcés-Mascareñas, B. (2014). Becoming less illegal: Deservingness frames and undocumented migrant incorporation. Sociology Compass, 8(4), pp. 422-432.

Coffé, H., and Tirions, M. (2004). Migrantenbeleid in Vlaanderen en Wallonie, een parallel perspectief. Ethiek en Maatschappij, 7(3), pp. 27-43.

COM (2004). Committee on the Elimination of Discrimination Against Women. Brussels. Retrieved from: https://www.eumonitor.nl/9353000/1/ j4nvkkpftveemt7_j9vvik7mıc3gyxp/vikqhırxtry5

De Genova, N. (2002). Migrant illegality and deportability in everyday life.Annual Review of Anthropology, 31, pp. 419-47.

Favell, A. (2010). Integration and nations: The nation-state and research on immigrants in Western Europe. In: M. Martiniello and J. Rath, eds., Selected Studies in International Migration and Immigrant Incorporation. Amsterdam: Amsterdam University Press, pp. 371-404.

Freeman, G. (2004). Immigrant incorporation in Western democracies. International Migration Review, 38(3), pp. 945-969.

Guiraudon, V. (2000). European integration and migration policy: Vertical policymaking as venue-shopping. Journal of Common Market Studies, 38(2), pp. 251-271.

Kalir, B., Sur, M. \& van Schendel, W. (2012) 'Introduction: mobile practices and regimes of permissiveness', in B Kalir \& M Sur (eds), Transnational flows and permissive polities: ethnographies of human mobility in Asia, University of Amsterdam Press, Amsterdam, pp. 11-26.

Knights, M. (1996). Bangladeshi immigrants in Italy: From geopolitics to micropolitics. Transactions of the Institute of British Geographers, 21(1), pp. 105-123. Knights, M. and King, R. (1998). The geography of Bangladeshi migration to Rome. Population, Space and Place, 4(4), pp. 299-321.

Kyle, D. and Siracusa, A. (2006). Seeing the state like a migrant. In:W. van Schendel and I. Abraham, eds., Illicit Flows and Criminal Things: States, Borders, and the Other Side of Globalization. Bloomington: Indiana University Press, pp. 153-176.

Lee, J., Carling, J., and Orrenius, P. (2014). The international migration review at 50 : Reflecting on half a century of international migration research and looking ahead. International Migration Review, 48(S1), pp. $\mathrm{S}_{3}-\mathrm{S}_{3} 6$.

Martiniello, M. (2003). Belgium's immigration policy. International Migration Review, 37(1), pp. 225-232. 
Martiniello, M. and Rea, A. (2003). Belgium's immigration policy brings renewal and challenges. Migration Information Source, Migration Policy Institute, Washington, D.C. Available at www.migrationinformation.org.

Menjívar, C. (2006). Liminal legality: Salvadoran and Guatemalan immigrants' lives in the United States. American Journal of Sociology, 111, pp. 999-1037.

Moch, L.P. (2003). Moving Europeans: Migration in Western Europe. Bloomington: Indiana University Press.

Torpey, J. (2000). The Invention of the Passport: Surveillance, Citizenship and the State. Cambridge: Cambridge University Press.

Soysal, Y.N. (1994). Migrants and postnational membership in Europe. Chicago: University of Chicago Press.

Sur, M. (2014). Divided Bodies: Crossing the India-Bangladesh Border, Economic and Political Weekly, vol. 46, no. 13, pp. 31-35.

van Meeteren, M. (2010). Life Without Papers: Aspirations, Incorporation and Transnational Activities of Irregular Migrants in the Low Countries. Rotterdam: Erasmus University Rotterdam.

van Meeteren, M. (2014). Irregular Migrants in Belgium and the Netherlands. Amsterdam: Amsterdam University Press.

van Meeteren, M., van San, M., and Engbersen, G. (2008). Zonder papieren: Over de positive van irreguliere migranten en de rol van het vreemdelingenbeleid in Belgie. Leuven: Acco.

Van Schendel, W. and Abraham, I. (2005). Illicit Flows and Criminal Things: States, Borders, and the Other Side of Globalization. Bloomington, IN etc.: Indiana University Press.

Zaman, S. (1996). Koekti Bohobol Golpo. Mowla Brothers: Dhaka.

\section{About the Authors}

Malini Sur is a Senior Research Fellow at the Institute for Culture and Society, Western Sydney University. She holds a Ph.D. from the University of Amsterdam (2012).

Masja van Meeteren is an Associate Professor in the Department of Criminology at Leiden University. She received her Ph.D. from Erasmus University Rotterdam in 2010. 



\title{
10 Disordering History and Collective Memory in Gunvantrai Acharya's Dariyalal
}

\author{
Riddhi Shah
}

Jones, Reece and Ferdoush, Md. Azmeary (eds), Borders and Mobility in South Asia and Beyond. Amsterdam: Amsterdam University Press, 2018 DOI: $10.5117 / 9789462984547 / \mathrm{CH} 10$

\begin{abstract}
This chapter argues that, despite hundreds of years of movement between East Africa and India through the Indian Ocean, histories of slavery are conspicuous by their absence in Indian and Gujarati collective memories. This lack of awareness and discussion of slavery in India has increased the danger of ignoring the presence and plight of the Siddi communities, whose African heritage still shapes their position in Indian society. Within this prevailing apathetic climate, Gunvantrai Poptabhai Acharya's novel Dariyalal, which centres on Ramjibha, a Gujarati slave trader turned abolitionist, assumes a double-sided significance. Acharya's fictive novel challenges mainstream Indian history, which has forgotten or deliberately omitted the recording and narrating of unsettling encounters and relationships. It helps us to confront the erasure of the non-European communities who played a role in abolishing slavery. Concurrently, Dariyalal is also a discursive tool for negotiating a Gujarati identity that is tied to slave trade. In the end, the novel upsets a Eurocentric history only to replace it with a Gujarati Hindu-centric version of the slave trade in the Indian Ocean, illustrating the lingering impact of migration and diaspora in the region.
\end{abstract}

Keywords: Gujarat, Gunvantrai Poptabhai Acharya, slavery, Indian Ocean 


\section{Introduction}

Over the course of the second half of the eighteenth century, Laxmichand Motichand, a prominent Vāniya (merchant) from the island of Diu at the southern end of the Kathiwar peninsula in present-day Gujarat, developed significant business interests in Mozambique, in southeastern Africa. He began his career as a young boy on Mozambique Island in the early 1760 s, apprenticing at his family's firm. He learnt Portuguese, the language of trade and the empire, and Emakhuwa, the African language of commerce. Soon he began climbing the commercial hierarchy and in the 1780 s became the firm's main partner in Mozambique. Like the other Vāniyās on the island, Laxmichand was heavily invested in the procurement and importation of Gujarati cotton textiles.

Textiles were one of Gujarat's chief exports and Africa's principal import. Laxmichand's imported Indian textiles, which were in high demand among African consumers, were crafted to suit African consumers' taste, styles, and designs each trading season. To be successful, he needed to be closely connected to agents in both the interiors of Africa and in Gujarat. Vital information was transmitted through multiple channels from Africa and India to Laxmichand in his firm in Mozambique. Placed at the centre of networks of procurement and distribution on both sides of the Indian Ocean, Laxmichand held an influential and significant commercial position, allowing him to further his firm's financial activities.

In the early eighteenth century, he began extending cloth-financed loans to other merchants along the coast and in the interior of Mozambique, aided by his firm's reputation as honourable and credit-worthy. His loans financed purchases of African ivory, which was sought by Indian consumers in Kathiawar and Gujarat for its durability and quality. He began to ensure that his ships bringing cloth to Africa would continue to be profitable on the way back to India by leasing valuable space in their holds for the transport of ivory. From the middle of the eighteenth century, the credit Laxmichand extended was increasingly used to fund the purchase of African slaves as Mozambique developed into an important source of slave labour.

One of the benefits of trading cloth with slavers was that Laxmichand often received payment in silver dollars. As slave trading expanded, so did the silver dollar as currency. The silver currency acquired by Laxmichand was shipped to India and used in payments to Gujarati bankers and to secure credit that helped his cloth and loan empire. Despite his deepening involvement in it, Laxmichand never redirected his business into the slave trade: his commercial focus continued to be on textiles and ivory. 
However, he did adapt to the changing reality of the time and Mozambique's economy. He invested in slaving and shipped small cargoes of slaves to India, where new military and domestic markets were cropping up. Ultimately, the exchangeability of cloth for silver allowed slave trading to expand and brought the markets in the Indian Ocean world into close relations with those in the southern Atlantic, forging trans-oceanic linkages in the eighteenth century.

Like many other Vāniyās, Laxmichand played a central role in the exchange, production, and selling of African slaves. His story, however, remains largely untold. Laxmichand's career is symbolic of the Vāniyā network in the western Indian Ocean, and thereby critical to our understanding of how oceanic relationships were mediated (Machado 2014: 1-18). Despite their significance, the Vāniyās' role in expanding slave trading has for the most part been forgotten save for a few scholars of the Indian Ocean, particularly in the collective memories of Gujaratis at the regional level and of the Indian nation as a whole.

As opposed to the history of Atlantic slave trading, which has been kept vigorously alive through various means including the arts, literature, and coverage in the mainstream media, histories of Indian Ocean slavery are conspicuous by their absence in Indian and Gujarati collective memories. In the Americas, art exhibitions in open public spaces, conferences, and fictional and non-fictional publications have kept the memory of slavery alive. Speech and artwork have produced and re-produced memories of slavery, leading to the institutionalization of this memory by organizations like the National Association for the Advancement of Colored People (NAACP) founded in the United States in 1909. Together, these discursive means have proven to be invaluable for starting discussions and reflections on the Atlantic slave trade and its contemporary effects. The bias of dominant European remembrance of slavery is relativized and challenged daily, by revealing the socio-political motivations and concealment tactics behind this bias (Haehnel and Ulz 2010). In sharp contrast, the lack of discursive means and material discussing slavery and challenging dominant positions has entailed the near absence of discussions on slavery and its after-effects in the Indian public space. It is certainly possible to argue that East Africa never played as important a role in the history of the Indian Ocean as it did in the Atlantic. This relative difference has sometimes been used as a justification for the deficit of discursive material on experiences of slavery and slave trade in the region (Alpers 1976). Doing so, however, increases the danger of ignoring the presence and plight of the Siddi communities of India, who are the descendants of African slaves. 
The Siddis reside in Gujarat, Hyderabad, and Karnataka - regions that historically served as central nodes in the network of maritime trade in the Indian Ocean. In North Kannara (Karnataka), the assimilation of the Siddis with the Indian populace and culture has been almost complete. Most have opted to convert to Hinduism; a few others have opted to become Christians or Muslims. Conversion, however, has not aided the social mobility of this community; they continue to live at the bottom of the social scale in the region and on the margins of poverty (Alpers 2000). In Hyderabad, the Siddis suffer from a similar fate. Centuries of neglect and marginalization has prompted many of them to refuse to be addressed as Siddis, which they believe represents being a stranger to the region (Yimene 2004:199). In Gujarat, their fate is even worse. There, Siddis are classified as Scheduled Tribes, relegating them to a place outside the caste system and reifying their African origins (Alpers 2000).

In this anaemic landscape of discursive practices around histories of slave trading, Gunvantrai Poptabhai Acharya's novel Dariyalal, the focus of this chapter, assumes a double-sided significance. Acharya is recognized as one of the most prolific writers in Gujarat. Influenced by stories told by sailors and his own father, who was a policeman in Colonial India, he has produced a massive body of literature on the sea and the adventures of sailors faring between Gujarat and Africa. His books such as ફાજી કાસમ તારી વીજલી (Haji Kasam's Vijli), દરીયાપાર (Across the Sea), હરારી (Harari), and દીલાવર પાષા (Dilavar Pasha) have made him one of the most widely read Gujarati authors. Of the 169 works of fiction Acharya has produced, દરયિાલાલ (Dariyalal) is by far his most popular (Datta 1987:15).

\section{The Story of Dariyalal}

Dariyalal follows Ramjibha, a Gujarati slave trader employed by one of the biggest Gujarati slave trading firms in Jangbar (modern day Zanzibar), which is headed by and named after Jeram Shivji. As the novel begins, Ramjibha is on his way to sell kidnapped Jangbaris. As the thirsty and famished kidnapped men, who are chained together, begin to lag, Ramjibha orders the group to take a short halt. As the group rests in the shade of a tree, one of the guards spots a rhinoceros nearby and, panicking, shoots the animal. Enraged, it attacks. The slaves attempt to run from the trampling beast, but, chained and shackled to each other, they are unable to flee. All but one of the men fall haplessly before the animal and are killed.

Unable to do anything besides look on with horror, Ramjibha witnesses the death of nineteen slaves. As he stands frozen in terror, Ramjibha remembers 
his Vaishnava upbringing. He is a slave trader, but he is also the son of a woman who helped injured animals and a father who forgave debts to help families. Unable to reconcile his choice of profession with his non-violence based upbringing, he vows to never again put a man in the 'demonic shackles'. Amid this epiphany, the twentieth man, who has miraculously escaped the rhino, wakes up from his faint. It is not long before Ramjibha realizes that the poor man had been driven mad by the attack and the death of his fellows.

This development hammers the final nail in the coffin. Ramjibha decides to not only quit the slave-trading business for good, but he will not stop until he puts a halt to the entire slave-trading enterprise in Jangbar. As the story further develops, Ramjibha is thrown into the local politics of Jangbar. He must function from within this framework and deal with other complex characters like Jangbar's Sultan Said Bin Suleiman, the thriving Gujarati slave-trading firm, and the arriving Europeans. Acharya's Dariyalal soon becomes a complex narrative of political intrigue, adventure, and just cause (Archarya 2000).

Although it was written in 1938, I argue that Dariyalal remains relevant today for two contradictory reasons. Border-crossing has always been a source of storytelling or narration. Indeed, Reece Jones' narration of Moushumi's trip across the India-Bangladesh border in Chapter 1, Andrea Wright's recounting of the working Indian women's emigration process in Chapter 6, and James Weir and Rohullah Amin's narration of Akbar's experiences on the migrant route in Chapter 7 are all meaningful examples of this. But people's experiences of crossing borders in this book and in the broader border studies literature are not merely an act of narration, or an attempt to promote understanding. These stories are moments that bear witness to border formation.

Borders, as they coagulate, begin binding more than physical territories: they begin to conceptually bind ideas and imagination. Successfully challenging these insidiously concretizing notions of the ideologies of the state and migration requires us to employ a myriad of techniques. Since public discourse is crucial in the (re)deployment of hegemonic ideas, we must not hesitate to expand from historic narrative techniques like those found in this edited volume to other genres like fiction in order to create moments of resistance to repressive border formations. In this context, fiction can be interpreted as a 'performative re-negotiation' of both tangible and intangible borders.

I argue that Gunvantrai Acharya's portrayal of Ramjibha's journey in Dariyalal is an attempt to imagine the diverse peoples who played a role in the slave-trading industry in Jangbar but who are excluded from Eurocentric accounts of history. The book confronts the erasure of the non-European 
communities who played a role in the abolition of slavery, and simultaneously plots character interactions that unsettle formal history and the current hegemonic imagination. Instead of attempting to demolish the identity boundaries created by linear histories, Dariyalal's plotline 'punches holes' in the mental walls of contemporary identity and linked history. Subsequently, he employs these characters and plotlines in endogenous Gujarati techniques to push on the rigid boundaries of European historiography.

Cognizant as I am of Dariyalal's role as a discursive tool that upsets Eurocentric history, I will also argue that the book replaces the male Eurocentric history of slave trade in Eastern Africa with a male Gujarati Hindu-centric version of the same. To quote Thapar, we 'choose histories that make us who we want to be', and Dariyalal is a prime example of this (Thapar 2010). In the struggle between the past, the present, and the future - a struggle that is not only historical, but also political - Acharya deploys Dariyalal as a discursive tool to re-imagine the Gujarati role in the African slave trade.

Acharya ensures the 'non-presence' of the Other in its plotlines, which is why the stereotypical depictions of Gujarati women and black slave bodies are never challenged in the narrative. This 'non-presence' of the Other in Dariyalal has had two significant consequences: first, although Dariyalal has been an important tool for displacing Europe in the collective Gujarati imagination, it has also reinforced traditional societal boundaries around the identities of black bodies, women, and inter-racial relationships; second, because of the reinforcing of traditional boundaries, Dariyalal actively prevents and mitigates meaningful conversations in the Gujarati community about its role in Indian Ocean slavery. In the end, Dariyalal contrapuntally is a tool that disorders European hierarchy by replacing it with a Hindu Gujarati male imagination in the collective memories of Gujaratis.

\section{Countering Linear Histories and Rigid Historiography}

Acharya's Dariyalal is structured in a format one might call racy. Ramjibha's story from slave trader to avid abolitionist spans several years. To cover this extensive physical as well as metaphysical journey, each chapter begins from a different timeframe that often covers months in a few lines. Sometimes a span of fifteen days is covered in less than ten lines; at other instances, a minute-long conversation is detailed over pages. The passage of time is not a linear movement. Intriguingly, the content page of Dariyalal, though arranged in a vertical fashion intimating progression, lacks chapter numbers leaving the reader to decide which chapter to begin or end with. 
The chapter 'The Suburb of Halar', which would normally be counted as Chapter 1, starts in 1844. 'The Wisdom of the Pyramids' - numerically Chapter 9 - takes us back to 1795 . Since every chapter is a small episode in itself, jumping from a chapter placed in the middle to one at the start does not really break the flow of the story or of the reader's thought. Funnily enough, I recognized this only after reading the chapters in a chronological order. Time and narrative appear to be closely linked for Acharya. The language and grammar of Dariyalal refer to temporality and temporality is, in turn, required to structure the narration of Ramjibha's journey. Unlike universalist models of temporality, however, time in Acharya's fiction is not linear and successive. Events in Ramjibha's life take place in time. Acharya indicates temporality by stressing at different hallmarks in Ramjibha's journey. The measuring of time is thus not inherent but is rather a function imposed on time as needed (Ricoeur 2002). The capacity of Ramjibha's fictional account to render multiple temporalities assumes greater importance than linear temporality when one realizes that the interactions between characters in this fictional account are a remembering of several unspoken histories.

Acharya pens diverse characters like the Gujarati slave traders Ladhabhai and Ramjibha; the priest Mahanta and his Hottentot tribe; English explorers Dunkirk and Park; Captain Stanley of the English Man-of-War Selbar; Sultan Said Bin Suleiman; Arab rescuers; runaway slaves; and the lamenting wives of people sold into slavery with equal weight and complexity. Throughout the story, each character interacts with two minor or major characters, if not more. While violence often tempers the complex interactions between the characters, this does not preclude other sentiments such as respect, admiration, understanding, and pragmatic cooperation. Take, for instance, the Sultan's reaction after being told an English explorer was missing: 'In his [sultan's] imagination he saw the tired and the hungry Dunkirk and in his heart he felt the warmth of one adventurer for another' (Acharya 2000: 61). Another example of a complex interaction is when the Mahanta ordered a Lion attack on Ramjibha for selling people into slavery. When the Lion refused to attack Ramjibha, Mahanta's character expresses perplexion. 'The worst punishment had failed. In his heart of hearts he developed a respect for this devil' (Acharya 2000: 53). Acharya reminds us of Gujarati culpability and collusion with the English in slave trading, and their contribution to the British Empire-building enterprise in the Indian Ocean. After the lion's refusal to attack Ramjibha, the Mahanta decides to hand him over to the women:

This was a temple where even the shadow of a woman was not tolerated... where did these women - young and old, beautiful and plain - come 
from? These were no ordinary women. These women were called 'God's Daughters'. When on the eastern and western coasts, the Arabs, the whites, the Indians and Chinese looted Bomas, burnt down Kraals and took away able-bodied men as slaves, these women were left behind without shelter, without hope, without help [...] The women came and surrounded Ram. His name was branded in fire in their hearts. He was [...] responsible for their present state. He was the desert wind that lays green fields barren [...] They scorned and they taunted... why don't you call your masters for help? Those across the ocean? Those who grow opium and cotton seeds? Who own sugarcane and indigo plantations? [...] Tell them their servant Ram is in great trouble. (Acharya 2000: $5^{1-52}$ )

The story keeps alive a record of slavery and the misery slave trading caused, which the Gujaratis would prefer to remain silent about. Yet another example of a remembering of multiple histories is the passage describing Dunkirk and Ramjibha's journey after escaping the Hottentot goma and fleeing into the jungle. 'They had a long way to go. Both were brave. Both had travelled alone and had much to talk about... As they talked the distance mattered less and less' (Acharya, 2000: 78). Dunkirk, amazed and bewildered after learning about the strength, influence, resources, and equipment Jeram Shivji's firm wielded in Jangabar, declares, "I cannot understand [...] Why don't you declare this land to be under your rule? [...] you have already established yourselves. Now to safeguard it you must grab power". Ramjibha futilely explains, "Our rule? But the Sultan rules this land? Why should we try to rule this land? We have come here to trade"' (Acharya, 2000, 79). Through the views explored by Ramjibha and Dunkirk in this exchange, Acharya presents a cultural perception of state violence. State violence in the Indian Ocean both before and after the arrival of the European powers has been an issue of contention and debate, spawning a large literature in and of itself. Dunkirk's views, which are given in considerable detail in this book, represent the political history of how European state violence was extended into the Indian Ocean. Conversely, Ramjibha's views represent earlier notions of free trade in the Indian Ocean. In the end, after listening to Dunkirk, Ramjibha becomes increasingly thoughtful. Here Acharya successfully illustrates the doubt, turmoil, and confusion generated in the aftermath of the imposition of a European understanding of trade and state violence on the region. Ultimately, like many discussions on this issue, Ramjibha and Dunkirk's discussion comes to a stalemate, with 'Dunkirk [thinking] Ramji was short-sighted' while Ramjibha felt Dunkirk was materialist (Acharya 2000: 81). 
The juxtaposition of multiple voices in Dariyalal's narrative calls to mind Romila Thapar's Somnatha: The Many Voices of History. In this treatise, she uses Persian, Sanskrit, and British historical sources to reconstruct how the destruction of the famous Somnath temple in India became a historical event of considerable magnitude. The sources are juxtaposed to reveal the process by which the 'traditional version' - wherein the destruction of Somnatha is associated with Hindu community trauma - is constructed in the House of Commons in Great Britain, and is subsequently adopted by the Hindutva ideology.

Dariyalal is a work of fiction and Somnatha: The Many Voices of History is a work of contemporary history. Even so, the objectives of both narratives are congruent. If Dariyalal is an attempt to keep alive the many voices of history via the fictive characters of Ramjibha, Ladhabhai, Stanley, Dunkirk, Jamadar, and Suleiman, Thapar's treatise does the opposite by deconstructing how mythology has become history in modern-day India. These works throw light on the 'many voices of history', for good or for bad. Both authors aim to recollect historical events from multiple perspectives and different angles. The difference between the two is that Thapar's work falls well within the bounds of how conventional historians write, while Acharya's fiction falls within Gujarati oral tradition that marries aesthetic value with its unique perceptive functions. Thapar's text attempts to 'objectively' outline the events that arouse varied sentiments in the modern context of Hindutva ideology, while Acharya's characters express sentiments in the context of historical events.

The western tradition of historiography may scoff at sentiment in historical texts, but sentimental history telling is not an uncommon phenomenon in Gujarati. Like Dariyalal, school children in Gujarat have for decades been taught to sing 'Haji Kasam's Vijli'. Also a subject of many fictive novels, the songs and novels about Haji Kasam recollect the actual incident of the missing Glasgow steamship Vaitarna in $1888 .{ }^{1}$ Referred to by the locals as Vijli ('lightning') and by contemporary accounts as 'Gujarat's Titanic', the steamboat disappeared off the coast of Bombay along with its 798 passengers (Gurav 2010). Here the gap between the historian and the society dissolves, as people themselves perform and listen to/read these events. Historical events become living history that people transmit and use to transform (Barz and Theil-Horstmann 1989: 1). Sung in a mournful tone, the song is a lament as well as a record of the tragic death of Haji Kasam, the captain of the ship and its crew. It is an 'embalming in memory' of the disappearance

1 'Vaitarna SS (1888) Document,' Wrecksite, n.d; Khambhayata, L. 2012 . સવાસો વર્ ષ પફેલાં ડૂડલલલી ગુજરાતી ‘ટાઈટેનકિં ફાજી કાસમની વીજળી!!». Sandesh Gujarati Newspaper (in Gujarati). 
of Gujarat's first lighting-equipped steamboat - a historical event of some magnitude for the people of Gujarat (Byock 2008).

The sentimental narration in Dariyalal should be treated in a similar way. Sentimental narration in Acharya's fiction serves to illustrate 'what it must have been like' for the natives of Zanzibar when slavery was legal. Acharya poses this question for the reader's consideration through the various encounters of the protagonists and their consequences. After witnessing the death of the slaves by the rhino, Ramjibha thinks to himself, 'How would he feel if he were made a slave? He heard the blood curdling whistle of the Rhino and saw his bloody dance for a moment. Aren't we like the rhino too? The black man must see us as two-legged rhinos' (Acharya 2000: 34). At a time when slave trading was legal, the sentiments evoked by the protagonists express the immorality of slave trade. Sentimental narration becomes a platform for Ramjibha to articulate his dissent to the prevailing norms of the time. History, then, is no longer a mere recording of events; by 'recuperating the commonplace experience of ordinary people', Dariyalal performs an affective history that is a reminder and caution against the repetition of historical mistakes (Phillips 2008).

Ramjibha's epiphany of the hurt and pain he was responsible for causing the natives of Zanzibar is brought about by several incidents. His witnessing of slaves being gored to death and his encounter with 'God's women' have been discussed briefly before. But it is in his final encounter with the mad slave, the only survivor of the rhino attack, where the slave convinces the Mahanta to release Ramjibha, that is representative of the Hindu karmic cycle in which each event has a domino effect on another. His encounter with the former slave, who saves him despite having been kidnapped and nearly sold into slavery, cements Ramjibha's determination to abolish slavery in Jangbar. He decides to confront Ladhabhai, the owner of the slave-trading firm, and eventually convinces him of the moral integrity of this decision. Ramjibha's conviction of the immorality of slavery is a narrative structure of mourning slavery in the Indian Ocean. ${ }^{2}$

\section{Storytelling and Collective Memory Making}

Acharya's sentimental narration of what it must be like to be a slave, Ramjibha and the Gujarati firm's participation in the slave trade, and Ramjibha's feelings of remorse require further in-depth analysis. In Dariyalal, Acharya 
employs sentimental historical narration to expertly detail how the same historical event is experienced differently. Acharya's elaborate descriptions of Ramjibha's repentance and Ladhabhai's unhesitating support for the stopping of the slave trade function to provide a measure of vindication to the Gujaratis, whose history is stained by that same trade. Acharya, who grew up in colonial India, could hardly have been impervious to popular accounts and descriptions of the Vanniyās that strongly implicated them in the slave trade. For instance, the Glossary of Anglo-Indian Colloquial Words and Phrases and of Kindred Terms published in 1903 offers several interpretations of the term Vāniyā or Banyan:

Banyan: A Hindu trader, and especially of the Province of Guzerat, many of which class have for ages been settled in the Arabian ports and known by this name [...] The word is adopted from Väniya, a man of the trading caste (in Gujarāti vāniyo), and that comes from Sansk. Vanij, 'a merchant' [...] The Banyan follows the Soldier, though as contrary in Humour as the Anti-podes in the same Meridian are opposite to one another [...] The men of this class profess an extravagant respect for animal life; but after Stanely brought home Dr. Livingstone's letter they became notorious as chief promoters of slave-trade in Eastern Africa [...] In trade these Banians are a thousand times worse than the Jews; more expert in all sorts of cunning tricks, and more maliciously mischievous in their revenge. (Yule and Burnell 1903: 63-64)

The Glossary's emphasis on trade and slavery's connection to Gujarati identity is not without reason. Gujarati merchants made use of African slaves from Mozambique Island, Macuana, and elsewhere along the Eastern African coastline in various capacities. They were put to work as sailors in voyages on Gujarati vessels that traversed the Mozambique Channel as far south as Delagoa Bay; utilized as quayside labour to unload vessels and carry textiles and other cargo to merchant warehouses; and as domestic labour in homes. Such was the Gujarati labour dependency on African slaves in Mozambique that the merchants collectively petitioned to reverse the ban imposed by the Portuguese in the eighteenth century prohibiting non-Europeans from owning and trading slaves. When all else failed, the merchants threatened to relocate to another part of East Africa should the Portuguese continue insisting on the prohibition (Machado 2014).

Given how critical Gujarati merchants were to the economic and financial life of the colony, Acharya's employment of the sentimental narration of Ramjibha's remorse and Ladhabhai's willingness to change must be viewed 
as a political deployment of discursive material to help Gujaratis perceive and construct their reciprocal identities. Individual memory can never discount collective memory; identity is therefore inseparable from collective identity. However, individuals can and do contribute to the process of identity-formation. Acharya's Dariyalal, based entirely on the sentimental narration of the experiences of a slave trader and a slave-trading firm, must be understood as a form of individual negotiation - an endeavour to enter, modify, and reconstruct the collective identity and collective memory of the Guajarati community using story telling as a discursive practice (Carli, Sussi, \& Kaučič Baša 2002).

On a closer look at Ramjibha's character, one cannot fail to notice that though many plots of the novel are endogenous to the Gujarati way of thinking, the transformation of Ramjibha's character into an adventure-seeking, risk-taking man with a heart of gold bears a striking resemblance to Rudyard Kipling's Victorian archetype of manliness (Eliot 1941: 273). Ramjibha is introduced as someone whose 'name spelt terror in the hearts of black men because he was known to be an expert at attacking the Bomas [...] black women cursed him but it meant nothing to him', but who transforms into a man that would pledge to 'uproot slave trade from Jangbar' (Acharya 2000: 5,72 ). In the process, the lone survivor of the rhino attack declares him to be 'the only man [...] trying to remove the tragedy [slavery] our people have been facing for centuries'. Even so, the depiction of Ramjibha as the saviour of the Jangbari black population was not sufficient: Acharya also felt the need to create a plot where Ramjibha rescues Dunkirk - an English adventurer - from death. This daring rescue provides Ramjibha's character with the sense of being able to walk as an equal with the white man, both metaphorically and literally, through the African wilderness, where the light and darkness [would] not bother them. Both were brave. Both had travelled alone and had much to talk about. About their countries and people, their clothes and customs and food and the adventures they had had' (Acharya 2000: 78). This is not to suggest that Acharya mimics Kipling, whose work was at its zenith of popularity with Indian readers in the 1930s-40s. In fact, Ramjibha is the epitome of Bhabha's (2004) hybridity.

Despite his crossing of the kala pani ('black sea'), which is generally believed to taint all those who dared to embark on overseas journeys - a belief that persists to this day-, Ramjibha is successful in staying true to his Hindu Vaishnav upbringing. His remorse links him to his Gujarati motherland; at his core, Ramjibha is traditional and religious. At the same time, he is also a modern man. He believes in the abolition of slavery - an ideal that puts his belief in line with the British colonial project of 'civilizing' the Indian Ocean. Ramjibha also proves excellent at handling modern technology and 
capable of rescuing brown women held hostage by pirates and even white men from the African wilderness. He therefore becomes the ideal Gujarati man: someone who is both traditional and modern at the same time.

However, Ramjibha's mastery of modern technology and progressive values such as the abolition of slavery are not possible in the absence of white male characters that reciprocate in kind. Acharya devises several plotlines where the White man - exclusively British in nature - is required to seek assistance from the Gujarati Halari community in Jangbar. We accordingly have Captain Stanley of the English Man-of-War, who is searching for Dunkirk and is directed to Ladhabhai - the only man with the resources to organize such a search. We also meet Dunkirk himself as he is rescued by Ramjibha. In asking for help, these characters never use coercion. They remain respectful and even admiring of the Väniyā's presence in Jangbar's financial and political life.

Acharya's portrayal of Ramjibha as the ideal modern-traditional Gujarati man is understandable. It is rooted in his loyalties to his religion and his regional identity. His depiction of white British characters, however, is curious. Nowhere in the book is the relationship between the two English men and the Vāniyās marred by a shadow of racism. Acharya's characters of Captain Stanley and Dunkirk cannot be attributable to notions of idealism alone. By the end of his book, the readers are also treated to the sight of grateful slaves, freed from their bondage, who 'One by one [...] bowed to the leaders [Ramjibha and Ladhabhai] and Rukhi. Anyone watching this spectacle would have seen an awe-inspiring sight. This was the zenith of Indian civilization, non-violence and humanism. It was a historic moment as the men left the town and headed back to the jungle' (Acharya 2000: 107). This is the first and the last time Acharya uses the term 'Indian civilization' in his book. Such diverse representations of Hindu Gujarat, the Empire, and the Indian homeland are an attempt on Acharya's part to mediate his own identity as a loyal subject of the Empire with a growing regional and national consciousness. This act of mediation must not be understood as Acharya having to choose between the King and the Country. At a time when the monolith of the Indian nation was in the process of being constructed, the diverse representations and characters in Acharya's book demonstrate that active mediation was indeed underway in his imaginary. Yet, it did not mean that the borders of those identities were either completely separate or clashing with each other, as we are bound to imagine today. On the contrary, if anything Acharya's brown and white characters live for the most in harmony. To put it simply, their identities were not boxed into separate compartments. Rather they existed on the same continuum. 
Figure 10.1 Ramjibha's Identity Tangent

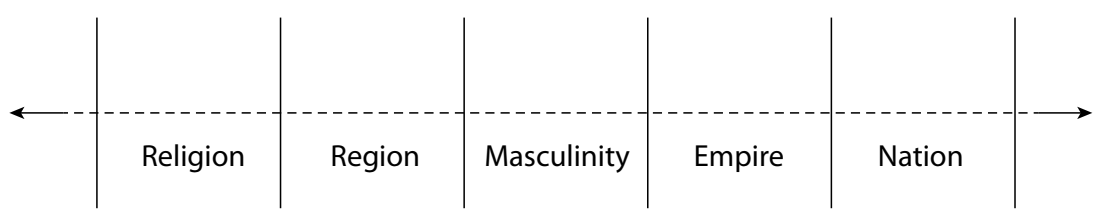

This also means that these identities need not necessarily be in conflict, and that the individual had flexibility in choosing what representation he/she would allow to dominate her/his identity. In contrast to Acharya's deliberate attempts to override the identity borders between white and brown men, a strict hierarchy of identity borders emerges through the 'non-presence' of the 'Other' in this novel (Carli, Sussi, \& Kaučič Baša 2002: 50).

In contrast to the brown and white male characters developed in the story, Acharya does not develop his female characters. In fact, there is barely any attention to the details or personalities of female characters in Dariyalal. The 'God's women' who move Ramjibha to tears with their laments appear together as a collective and as a tool to emphasize the absence of men in their own society. A brown Gujarati woman, Rukhi, appears at the very end of the novel, only to be held hostage by pirates. As a hostage, Rukhi gives Ramjibha the opportunity to mount a daring rescue, thereby demonstrating his respect for all Gujarati women and his fearlessness by putting his life at risk to rescue 'sister Rukhi' even from the 'depths of dariyalal [the beloved sea] (Acharya 2000: 87). When her husband dies, Rukhi immediately chooses to leave Jangbar in her widow's garb for Kashi to spend her life mourning on the banks of the river Ganges for her husband. Neither Ramji nor Ladhabhai attempt to dissuade her from spending her life mourning for a person who had been absent for the better part of her married life; in fact, Ramjibha takes on the responsibility to deliver her safely to Kashi.

Next, Acharya depicts, in some detail, a character that is for the most part referred to merely as the 'black woman'. Though freed by Ramjibha, she returns to her previous owner Lalia, who turns out to be Rukhi's husband. She tends to Lalia, heals him, and helps him regain his health, only so he can play a key role in freeing Ladhabhai's fortress from the Arab army. It is only in the end that her name is revealed to be Bashuta, and we never learn of her fate.

Finally, we have Acharya's treatment of the black slaves on whose shoulders rest the depiction of Ramjibha as a remorseful former slave trader attempting to shift the very foundation of Jangbari society. Except for the 
Mahanta (the Hottentot priest), black bodies in the novel are given no names or personalities. For the most part they appear as a collective: 'twenty slaves', 'God's Women', 'the Hottentot tribe', and so on.

The systematic 'non-presence' of women and of the black population in Jangbar in Acharya's novel serves to reinforce identity borders and ultimately to repress the 'Other'. We see Rukhi sailing to Jangbar by herself without a male protector. The revolutionary nature of her action - since women did not regularly travel to Africa - is cloaked by searching for her husband. It appears that Rukhi can only cross literal borders by travelling across the ocean if she is looking for her husband - that is, if she is guarding the borders of her own traditional devoted-to-husband identity. In this sense, Rukhi is an ambassador of the traditional Gujarati identity to Jangbar. While Acharya is willing to let Rukhi cross regional borders, however, he is unwilling to cross the border of an inter-racial relationship with the characters of Lalia and Bashuta.

Acharya's description of these two characters after Ramjibha releases Bashuta from slavery hints at an intimacy between them. After Bashuta nurses him through sickness, Lalia makes a choice to remain with her instead of returning to his wife Rukhi. In the beginning, Bashuta's character is shown to be deeply in love and committed to Lalia, while Lalia accepts her ministrations because 'his manhood had been compromised' when Rukhi was kidnapped by the pirates. Over time, Lalia loses his anger with Rukhi and decides to love Bashuta, who 'was turning him into a human being'. However, their relationship never proceeds further than this. Lalia and Bashuta are never shown pondering marriage, and by the end of the book Lalia has sacrificed himself to save the Vāniyās - leaving Bashuta to her own devices. In their brief relationship, Bashuta never stops referring him to as 'master' and Lalia is never shown to think of Bashuta without also thinking of Rukhi.

Rukhi and Bashuta are the only female characters given more than a few lines in Acharya's novel. The integrity of their identities depends on their invisibility: it is only through the conspicuous absence of the black Jangbari population and women can Ramjibha achieve prominence. Their absence makes it possible to depict Ramjibha as a brute capable of terrorizing and subjugating the entire population in Jangbar according to the policies of a slave-trading Gujarati firm, and then as that same population's protector and saviour. Acharya creates a hierarchy in which the black body is waiting on the bottom rung to ascend and take his place beside the brown and white man. In other words, he displaces dominant Eurocentric ideas only to replace them with a narrative of Gujarati Hindu dominance. 
The 'non-presence' of the Other and the prioritization of a Gujarati male identity in Dariyalal fosters the tendency to repress potential discussions and debate surrounding the issue of slavery and/or the treatment of women. When Dariyalal, which was already popular with Gujarati readers, was made part of the Gujarati curriculum, this selective construction and representation was normalized - which, in the absence of other competitive discursive tools, defined how this society remembers its past history of slavery and its aftermath.

\section{Conclusion}

Dariyalal is a work of imagining psychological, emotional, and cultural histories that informs, or dis-orders, our thinking that is based on analytical historical discourse that tells us what happened in 'reality' (Handoo 2006: 23). The fact that the book has been reprinted several times, with the latest edition printed in 2000, suggests that it continues to be popular and perhaps engenders meaningful discussions on Gujarat's seafaring history, racism, and communal relations among children and adults in contemporary Gujarat. In the long history of historical writing, the idea that history provides a window to the question 'what was it like' has arrived late on the scene, and even then is yet to make a mark.

History has traditionally been thought to be the desire to record events, followed by the need to explain them. However, with the ever-expanding horizons of modern historiography and the new desire to reach beyond analysis and narration, history now requires sources that Western historiography may consider non-traditional and innovative at best and illegitimate at worst (Phillips 2008). Historical fiction is an illuminating genre that interrogates the set practices of history and its texts. Historians may be fans and even authors of historical fiction, they may read such novels voraciously and even assign them as readings. The truth, however, is that historians for the most part do not consider them worthy of critical engagement. Unlike alternative representations of history like memorials, historical films, artefacts in museums, and historical photographs, historical novels are yet to be completely included in scholarly work (Pinto 2010). Within this set of challenges, Gujarati historical fiction faces even higher hurdles in a discipline that is dominated by English-speakers and -writers.

At the same time, Acharya's Gujarati novel could have been a better vehicle for communicating the cultural trauma of slavery to the Gujarati descendants of slave traders if it had not erased female and black characters. 
'Cultural trauma' refers to a 'dramatic loss of identity and meaning, a tear in the social fabric, affecting a group of people that has achieved some degree of cohesion' (Eyerman 2001: 2). This trauma may not necessarily have been felt directly by everyone in the present Siddi community, or even the whole community itself in India. However, its traumatic meaning is established and accepted through processes of mediation and representation over long periods of time. Acharya's refusal to push the boundaries of traditionally held identities, instead of the relatively radical re-envisioning of identities like that accorded to Ramjibha's character, was the loss of an opportunity for the public acceptance and credence of the memory of what it must have been like to be a slave. Dariyalal was perhaps one amongst many that forwarded selective mediation of experience and representation as a discursive tool. Such a discriminatory construction of events has led to a near-absence of efforts to grapple with the nature of the victim and to fully undertake the responsibility for these historical events. This lack of struggle over the meaning and the consequences of the slave trade continue to create a crisis of identity and meaning for the descendants of slaves in India.

In imagining a world where a Gujarati man plays an anti-hero at the centre of slave trade in Jangbar, Acharya challenges the financially and politically strong communities who have managed to erase themselves from much of the history of the slave trade. Originally written in Gujarati, the story defies expectations and strongly paints the community in shades of grey. By imagining the involvement of the community in the slave trade, Acharya narrates a much more cosmopolitan history of systematic oppression. Because it is a work of fiction, Dariyalal transcends cultural ghettos. It does not claim to demolish the painstaking boundaries and frontiers that nations have created. Rather, it punches holes in the mental walls of contemporary identity and linked history. Through these holes in the wall we are afforded a glimpse into the 'Other' - an(other) identity in an(other) time - as we rethink borders and mobility in South Asia and beyond (Shafak 2010).

\section{References}

Acharya, G. (2000). Dariyalal. Gujarat: Dictum.

Alpers, E. (1976). Gujarat and the trade of East Africa, c. 1500-180o. The International Journal of African Historical Studies, 9, pp. 22-44.

Alpers, E. (2000). Recollecting Africa: Diasporic memory in the Indian Ocean world. African Studies Review, 43, pp. 83-99. 
Barz, R. and Theil-Horstmann, M. (1989). Living Texts from India. Oxford: Oxford University Press.

Bhabha, H.K. (2004). The Location of Culture. New York: Routledge.

Byock, A.M. (2008). Embalming in memory: Mourning, narrativity, and historiography in the nineteenth-century United States (Doctoral dissertation, Northwestern University).

Carli, A., Sussi, E., and Kaučič Baša, M. (2002). History and stories: Identity construction on the Italian-Slovenian border. In: U. Meinhof, ed., Living (with) Borders. Hampshire, England: Ashgate, pp. 34-51.

Datta, A. (1987). Encyclopaedia of Indian Literature. New Delhi: Sahitya Akademi. Eliot, T.S. (1941). A Choice of Kipling's Verse. London: Faber \& Faber.

Eyerman, R. (2001). Cultural Trauma: Slavery and the Formation of African American Identity. Cambridge: Cambridge University Press.

Gurav, R. (2010). Freedom fighter's kin keen on making Indian Titanic. Mid-Day, 15 August.

Haehnel, B. and Ulz, M. (2010). Slavery in Art and Literature: Approaches to Trauma, Memory and Visuality. Leipzig: Frank \& Timme GmbH.

Handoo, J. (2006). The palace paradigm and historical discourse. In: M.D. Muthukumaraswamy, ed., Folklore as Discourse. Chennai: National Folklore Support Centre.

Machado, P. (2014). Ocean of Trade. Cambridge: Cambridge University Press.

Mitra, C. (2004). The hidden agenda: Review of Romila Thapar's Somnath. India Today, 16 February.

Phillips, M. (2008). On the advantage and disadvantage of sentimental history for life. History Workshop Journal, 65, pp. 49-64.

Pinto, S. (2010). Emotional histories and historical emotions: Looking at the past in historical novels. Rethinking History, 14(2), pp. 189-207.

Ricoeur, P. (2002). Narrative time. In: B. Richardson, ed., Narrative Dynamics: Essays on Time, Plot, Closure, and Frames. Columbus: Ohio State University Press, pp. 35-45. Shafak, E. (2010). The Politics of Fiction. Presentation given for Ted Talks. http:// www.ted.com/talks/elif_shafak_the_politics_of_fiction?language=en

Thapar, R. (1989). Imagined religious communities? Ancient history and the modern search for a Hindu identity. Modern Asian Studies, 23(2), pp. 209-31.

Thapar, R. (2005). Somanatha: The Many Voices of a History. Verso, London.

Thapar, R. (2010). Romila Thapar: On historical scholarship and the uses of the past (interview with Parita Mukta). Ethnic and Racial Studies, 23, pp. 594-616.

Yimene, A. (2004). An African Indian community in Hyderabad: Siddi identity, its maintenance and change (Doctoral Dissertation. Göttingen: University of Göttingen).

Yule, H. and Burnell, A.C. (1903). Hobson-Jobson: A glossary of colloquial Anglo-Indian words and phrases, and of kindred terms, etymological, historical, geographical and discursive. London: J. Murray. 


\section{About the Author}

Riddhi Shah is a Ph.D. Candidate in the Political Science Department at the University of Hawai'i at Mānoa. Her dissertation focuses on the dispossession of coastal communities, who are being framed as 'security threats' to global trade in the rapidly securitizing space of the Indian Ocean. Prior to her doctoral studies, Riddhi worked as a Research Assistant at the National Maritime Foundation, New Delhi, India. Her views on maritime terrorism and piracy have been published in journals and commentaries. She has M.A. degrees from the University of Sussex, Brighton, UK in Conflict, Security, and Development and in Disaster Management from the Tata Institute of Social Sciences, Mumbai, India. 



\title{
$11 \quad$ Fragmented Lives
}

\author{
Locating 'Home' in the Poems of Sudesh Mishra
}

\section{Tana Trivedi}

Jones, Reece and Ferdoush, Md. Azmeary (eds), Borders and Mobility in South Asia and Beyond. Amsterdam: Amsterdam University Press, 2018 DOI: $10.5117 / 9789462984547 / \mathrm{CH11}$

\begin{abstract}
The work of Sudesh Mishra, a contemporary Fijian-Indian-Australian poet, addresses the idea of the fragmented diasporic identities of IndoFijians and the ability to locate a 'home' amidst borders of history, memories, and intergenerational remembrance. There is an attempt at understanding the nature of the memories that sustain the ethnic borders that still exist in Fiji, and give rise to racial and ethnic tensions. Far from being geographical in nature, the borders in Fiji are mostly historical and psychological, and the history of colonization and indenture constantly reiterate the presence of borders that cannot be dissolved or reconsidered. In times of globalization and multiple border crossings, the study of the Indo-Fijian diaspora offers dislocated sites of contestation of the homogenizing forces of globalization. And it is precisely these sites of dislocation and instability that create possibilities of redefining a home for a diasporic community, a home that travels and traverses time and space to become more inclusive and comprehensive.
\end{abstract}

Keywords: Indo-Fijian, diaspora, memory, borders, home

\section{Introduction}

How do theorists of border studies and transnationalism capture a state of being that is fluid and exilic, and that attests to remembering, rather than forgetting, the anguish of the self? How do memories shape the consciousness of not just an individual, but also a nation that must come to terms with historical trauma and dislocation? In times where state and national borders are becoming increasingly elusive, fluid, and mobile, the positions 
of certain populations are shifting from disadvantaged and peripheral to become important participants in dialogue and expression. Such interfaces create new avenues for understanding the existence and perpetuation of the borders that run deep in a nation's psyche, and deeply engage with memory studies as a tool for understanding how, and how much, a nation remembers. Fiji is one such site where memories of the borders and conflicts that emerged in the process of nation-building continue to thrive, affecting the political and cultural landscape of the nation.

This chapter seeks to understand the notions of borders, home, and belonging of the Indo-Fijians through the poetry of Sudesh Mishra, a contemporary Indo-Fijian-Australian poet. Mishra's poems engage deeply with the memories and postmemories of intergenerational remembrance that significantly contribute to identity formation and the development of a diasporic identity - especially in the case of Fiji, where borders of race and identity run very deep and are placed against the history of colonialism, indenture, and coups. In a constantly changing landscape shaped by mobilities and positionalities, the idea of a citizenship that is tied to the terrain and imagination of the nation-state is called into question (Anderson 1991: 6). Turbulent political conditions over the last 30 years have led to large-scale migrations of the Indo-Fijians, raising significant questions about the community's citizenship and belonging to the land of Fiji. This chapter is an attempt to understand the nature of memories that sustains the ethnic borders that still exist in Fiji, thereby giving rise to racial and ethnic tensions. Beginning with a summary of the historical conditions of girmit ('indenture') in Fiji and a brief overview of the coups, this chapter explores the nature of memory, postmemory, and identity in diaspora, finally establishing that the possibility of envisioning a singular, stable home for Indians in Fiji is severely challenged by the constant movement, displacement, and borders inherent to a diaspora.

Sudesh Mishra is the author of five books of poems: Rahu (1987), Tandava (1992), Memoirs of a Reluctant Traveller (1994), Diaspora and the Difficult Art of Dying (2002), and The Lives of Coat Hangers (2016). He has also written literary criticism, including Diaspora Criticism (2006) and Preparing Faces: Modernism and Indian Poetry in English (1995); two plays, Ferringhi (2001) and The International Dateline (2001); and several short stories. His writing problematizes the nature and meaning of home, which is a dynamic and complicated process made more complex by the political instability of the nation. The nature of his conception of 'home' contradicts the usually understood notion that home is a stable, secure, fixed place of belonging that evokes beliefs of citizenship and nationality. 


\section{The Bitter Land of Fiji: Grappling with Internal Borders}

I am of Feejee,

The bitter land of Feejeee,

And hate is all we know,' cried she,

'Leap down that mango tree

And dance with me

In this bitter land of Feejee. (Mishra 1992: 19)

The year 2016 marked the 1ooth anniversary of the abolition of indenture in Fiji, a system under which the colonial government transported about 40,000 Indians to work on the sugarcane plantations on the islands. The Indian diaspora to Fiji can be described as following two waves of migration. The first wave began in May 1887, when the first ship carrying Indian indentured labourers arrived in Fiji, most of them from Uttar Pradesh, a North Indian province, and Calcutta, in eastern India. ${ }^{1}$ Indians ventured abroad in anticipation of economic gain, but what began as a hopeful quest turned out to be a never-ending journey of tyranny, disillusionment, and despair. These labourers signed a contract or an agreement (known as 'girmit', a corrupt form of the English word 'agreement'), under which they continued to arrive in Fiji until 1920 when the system was abolished. After abolition, their living conditions improved. It is estimated that about 24,000 of the indentured migrants and their families returned to India, but the majority stayed in Fiji (Lal 2009: 89-109). The Fijians owned 87 per cent of the land and after the indenture ended it was leased out to Indians who earned their livelihood working on plantations, so that they could gradually work towards a better future. Indians eventually came to dominate trade and commerce in addition to agriculture; in particular, the free Gujarati migrants who arrived in Fiji from 1914 onwards established themselves as traders, and became the face of Indian commercial success (Mishra 2002: 154). While first-generation migrants were predominantly labourers, the second and third generations of Indo-Fijians established a strong economic and cultural base in Fiji.

$1 \quad$ Migration was never a part of Indian society; in fact, as historian Brij Lal states, most Indian peasants sent away to labour in fields, were bound to soil and would have never thought of leaving or exploring unknown lands, across the seas. During the late nineteenth century, however, rural India was undergoing profound changes due to the introduction of new land ownership regulations, increasing debts, and natural calamities such as droughts and famines. Out of the 6o,00o migrants who came to Fiji at this time, 45,00o came from Uttar Pradesh, a state in Northern India that was most severely affected by drought and famine (Lal 2009). 
The second wave of diasporic migration happened in the wake of the two military coups of 1987 followed by one in 2000 and the last one in 2006 , when communities of expatriate Indo-Fijians formed in other countries. ${ }^{2}$ After the 1987 coups, some 70,000 to 80,00o Indo-Fijians migrated to Australia, New Zealand, Canada, and United States. As the historian Brij Lal states, 'Indo-Fijians, now fourth or fifth generation, are thought to be still regarded as outsiders in the land of their birth, threatened with the denial of equal citizenship and equal protection of law' (Lal 2000:180). The coups were an outcome of a deep-seated belief, in Lal's words, that the taukei ('Fijians') regarded their neighbours the Indo-Fijians as vulagi ('foreigners'), who were welcome to stay and enjoy their hospitality as long as they recognized that, as outsiders, they do not have a claim to the land. Indo-Fijians, now in their fourth and fifth generations, still feel threatened about being denied the rights of equal citizenship and protection under the law. This can be traced to the history of colonial rule, which ruled through racial and ethnic compartmentalization that lead to a lack of inter-group contact and ultimately resulted in a severely fragmented society. A culture of mistrust arose from the promotion of 'ethnic-blocs' by an alliance between indigenous Fijians chiefs and the European community, who opposed the Indo-Fijians who were pushing for independence. As a result, there was a clear polarization of the communities post-independence, and inter-group contact continued to be dominated by an ideology of indigenous paramountcy, without any effort toward inclusive nation-building, a national identity, or even equal citizenship. This eventually undermined the formation of a socioculturally plural society that recognizes the existence of diverse social, cultural, and sub-national groups and their significance for nation-building. Instead, the struggle for ethnic dominance and superiority led to racial violence and military interventions, belittling any attempts at meaningful inter-group dialogues and peaceful coexistence. This led to four coups over the span of twenty-one years, the first two against a multi-ethnic government in 1987, and one against the multi-ethnic People's Coalition Government in 2000 and the final one in 2006, aimed at asserting indigenous hegemony over the nation and its politics. Widespread unrest and violence led to

2 While most political analysts/historians view the events of 1987 as comprising two coups d'état, one in May and one in September, others describe the situation as one coup that began in May and ended in September/October. Though the second military intervention in September 1987 did not depose a formally recognized government, I adopt the former position as the more commonly recognized one. Consequently, I refer to four coups in Fiji's recent history: May 1987 , September 1987, 2000, and 2006. 
the delegitimation of the democratically elected government, constitutional values, and minority rights, sparking fear and insecurity for the Indo-Fijian minorities.

The study of borders in Fiji offers a prismatic understanding of the society and of the space that signifies home for Indo-Fijians. During all of these coups, particularly the first three, Indians suffered both economically and psychologically. Satendra Nandan, an Indo-Fijian writer and historian, encapsulates the Indo-Fijian experience thus: 'As a migrant, stripped much of his history, his human dignity, his roots, once again uprooted by the coups, the twice-banished, thrice-betrayed, had to live by his wits' (2000: 15). Nandan believes that the tragedy of Fiji is that Indians and Fijians have lived in separate cultural worlds, largely caused by colonial policies and continued by communal performances such as attending different schools and places of worship; practicing different lifestyles, rites, rituals, and ceremonies; speaking different languages (Nandan 2000: 14). The creation of such distinct boundaries is problematic because they impede any attempt for communities to integrate or even have the meaningful dialogues that are required to create homes. The coups were therefore an outcome of economic and political power struggles between the two communities, Indo-Fijians and Fijians - a struggle that can be traced back, again, to the colonial policy of apartheid. The Indo-Fijian scholar and literary theorist Vijay Mishra states that, although Fiji has been 'postcolonial' since its independence from Britain in 1970, for the native Fijian the coups signalled their moment of anti-colonial struggle by re-defining what indigenous people meant by rights and the social democratic notion of the common good. Curiously enough, this moment of postcolonial affirmation could only happen with demonstrable claims of indigenous Fijian supremacy over the migrant, albeit thoroughly Fiji-born, population of Indo-Fijians (Mishra 2007: 37). With multiple coups, the Indo-Fijians' sense of exile and borders was perpetuated, invoking memories of indenture and their original displacement.

Seen as the remains of an old capitalist endeavour and symbols of imperialism, Indians remain aliens in the land of Fiji. In his poem 'Feejee', Sudesh Mishra expresses a state of disarticulation and dispossession which must be read against the history of the coups of 1987 and 2002, which were a grim reminder of Indo-Fijians' status as outsiders on the island:

We have forsworn our landscape; there's nothing

But the throng of disarticulate words

Searching for meaning in a barren skull.

Is this the madness of the deracine? 
Or the confusion of some imbecile?

Both betray the mendicant's way. Old man,

Who shall render our world meaningful?

Define our dispossession? Like primates

Sharing gutturals in a brittle cave,

We strive for articulation, shaping

Each vowel from the stiff bone of language.

And though words, like the affairs of the heart,

Are ephemeral, and will not redeem,

Ours is the simple faith in what is said. (Mishra 1992: 17)

The images of uprooting and the confusion brought about because of it, the struggle to articulate this state and the inadequacy of language to convey it, all express the insecurity and sadness of an Indo-Fijian community that has suffered threats of expulsion and ethnic cleansing, with the coups deepening the divide between the communities. Military rule, curbed rights, and minuscule representation at the political level have since led to large-scale migration of Indians. Since the coups, more than 100,00o Indians have left, especially professionals (Srebrnik 2008: 95). Fiji is a plural society where economic and social activities are clearly segregated and compartmentalized; homes created on such borders are unstable and uncanny, often giving way to confusion. Borders constantly define and negotiate the spaces that we know as home, blurring the boundaries between the mental and physical/geographical home, and oscillating between the past and the present.

\section{Postmemories of Girmit}

The generations of Indians in Fiji who descended from the girmitiyas ('diasporic indentured labourers') keep their memories of dislocation and pain alive through the intergenerational transfer of memory, known as 'postmemory' in the words of Marianne Hirsch. 'Postmemory characterizes the experience of those who grow up dominated by narratives that preceded their birth, whose own belated stories are displaced by the stories of the previous generation, shaped by traumatic events that can be neither fully understood nor re-created'3 (Hirsch 1992). The term originally referred

3 First used by Hirsch in 1992 in her article on Art Spiegelman's Maus, this term falls under the large canopy of memory studies, a term she explored in greater depth in her 1997 study 
primarily to the relationship between the children of Holocaust survivors and the memories of their parents. Since then, the term has been opened up to include the relationship that later generations or distant contemporary witnesses bear to personal, collective, and cultural trauma - of others, as well as the experiences they 'remember' only through stories, images, and behaviours. Through postmemory, events of the past continue to haunt the present. Collective national and family memories that are transmitted from one generation to the other through political, social, historical, testimonial, and documented memories create an understanding of home, which instils a sense of belongingness to the past and the present. However, in certain cases memories can also induce trauma caused by historical displacement and exploitation, as in case of Indians in Fiji. Geographical and temporal distance and the trauma of exile or expulsion make it difficult for diasporic communities to develop an integrated memory of their lost home. Postmemories of indenture and servitude play a significant role in shaping the worldview of the contemporary generation of Indo-Fijians, who have witnessed multiple political coups and racist tensions in the last thirty years.

Contemporary theories of borders engage in interdisciplinary approaches to studying postmodern identities and spaces of belonging. Understanding the border as a literal visual object such as a wall, fence, gate, and line on a map has been a traditional practice. Moving beyond understanding borders in terms of the territories that define nation, identity, and belonging, however, border studies engages with understanding the nature of borders in reference to the politics of representation and interpretation and the global movements of people. Often used interchangeably in literature, the terms 'border' and 'boundary' are distinct. While 'border' suggests a geographical space that divides different locations, 'boundary' refers to the cognitive divisions that exist between people. Questions about internalized borderlands based on history, caste, religion, gender, and ethnicity need to be addressed, redefined, reframed, and rediscovered. One way these questions can be addressed is by foregrounding the role of the memories and colonial discourses that shape the narratives of the self and community of a nation. Memories play a significant role in the formation of diasporic identities because transnational communities' association with their homelands does not come from strong filial bonds, but through transgenerational memories - Hirsch's postmemories. Consequently, it is not territories or borders that determine the formation of distinct identities, but instead postmemories, which also regulate and sustain these identities. 
For the second and subsequent generations of Indians in Fiji, the island is their homeland, the land of their birth. However, they also have postmemories of 'imagined India' handed down to them by the older generations and through religious texts and the popular media. While most of the Indians born in Fiji would never be able to relate to India as a homeland, they are constantly reminded that they are Indians in Fiji. The home they call Fiji therefore becomes a contested site, and raises questions of what exactly constitutes home. For instance, in his poem 'Nightfall', Mishra narrates the plight of a migrant haunted by displaced dreams:

Evening.

Mynahs are prunes moving against the sky.

The diminishing light holds me together,

Buttressed in retrospect:

A Brahmin Nana rehearsing

His father's dream

Exchanged Lucknow for a vision stretched miles into the ocean.

The lawn is treed in shadows.

Beyond the road sugarcanes inject the night with stars.

The sky's gourd leaks profusely, pigmenting

The west with burgled colours-

Of Madras, Bombay.

Even when the scourge snaked over shoulders

The mind stayed focused-

Ayodhya was more real than agony or arkathi. ${ }^{4}$

It is different now, here, on this island;

I glare with post-lapsarian orbs

Stranger even to darkness. (Mishra 1987: 22)

This stanza invokes the postmemories of the girmityas who were recruited through fraudulence and deception, and who would never have dreamt of leaving their homes for unknown places. The poet reminisces about an old Brahmin from Lucknow against the backdrop of Fiji's sugarcane 
plantations, recollecting memories of his life in Ayodhya ${ }^{5}$ - revealing the blurred boundaries of past and present, belonging and un-belonging. The uncanny repetition of the pain and loss of a homeland give rise to postmemories of an indentured past that haunts the texts produced in the present. 'A Well', for instance, reminds Mishra of a palimpsest, with each generation adding layers to the ancestral experience, and attributing newer meanings to it. Farmhands working near the well echo the experience of his forefathers who dug through the sod with machetes and ploughs, and invoke memories of khol-eyed women snapping beans and gossiping. An old cartwheel rotted from its axle, rusted bolts, an old box standing like a milestone, all remind him of his ancestors. Standing there, he says,

I wish to unpack

The bracken-wrapped mandala of my ancestors,

Take up pitchfork and machete and plough,

And do what farmhands do, till clods of earth

Glisten for the ploughshare, and new generations

Of children, starting at night from humid dreams,

Wonder what ghost claps in our unlit catacombs (Mishra 2002: 42)

The well and the landscape surrounding it signify a space that reverberates images and sounds from the past. Mishra wants to unpack this 'mandala' or ancestral universe for the new generation that must relate to the past to make sense of the present, and this he does through his poetry. In another poem, 'Dear Syd', Mishra relives the nightmare of the Syria, ${ }^{6}$ a recurring historical trope in Mishra's poems:

5 Ayodhya is a city in Uttar Pradesh, India, that is believed to be the birthplace of Lord Rama and the setting of the Hindu epic Ramayana. Through the invocation of Rama's banishment, his trials in the forest, the abduction of Sita, his victory over Ravana, and their final return to the utopian Ayodhya, the nineteenth century girmitiyas recast their narrative through 'reverse millenarianism'. India signified Ayodhya, and by extension, the golden age that they forfeited through their crossing of kalapaani ('the black waters'). The story of Ram resonated with the emotions of the Fijian Indians, who believed that like Ram, who was exiled for fourteen years without any fault of his (in their case they were misled and deceived by the arkathis who showed them a utopian picture of life in Fiji), eventually returned to Ayodhya, triumphing the good over evil. This myth consoled them and gave them hope of escaping indenture and returning to Ram rajya ('the kingdom of Ram'), which signified India.

6 Considered the worst maritime disaster in the history of Fiji, the S.S. Syria was a ship carrying immigrants from Calcutta to Fiji that wrecked on 11 May 1884. An inexperienced crew had allowed the Indian immigrant ship to drift off course, and it was wrecked on the Nasilai reef at Nakelo in Tailevu at 8:30 PM. 497 men, women, and children were on board, and many had never seen water before they had embarked on the voyage. The unforgiving reef decimated the 
And in nightmares the cries from broken Syria

Break me like no book-the splintering hull,

The seething ocean, the human struggle;

Afterwards the wash of sea and a silence.

These images won't let me be, macheteing

Through my equanimity, sinking the coracle

Bobbing inside my archipelagic heart. (Mishra 1992: 27)

Though he neither witnessed nor experienced this event first-hand, the cries of people struggling against the unrelenting sea, followed by a long silence of amnesia, still haunt Mishra, filling him with despair and shaking his composure, even after more than a century.

The postmemories of trauma passed on through intergenerational narratives, prevent the possibility of forgetting such events that marked important times in the history of Indians in Fiji. Certain landscapes, such as the cane fields of Fiji, are reminders of a time from the past. These fields are the actual sites where the Indian girmityas sang songs of longing and mourning for a lost homeland, where the capitalist venture of the girmit ('agreement') to work was realized. These fields remind Mishra of not just one lost home - the one that the Indians left behind in India -, but also the other lost home that he was born into, and which was ravaged by coups and racial tensions. The space of the fields, therefore, blurs the borders of time, memory, and history, where both bleed into each other and waver between different times of history:

Green spears lancing heaven, column after column,

Proud, rigid. No Macedonian prepared this phalanx, Just a bunch of bedraggled Biharis ${ }^{7}$

Emerging from the lagoon like some promised mirage,

And the sea sang estrangement to displaced ears.

$[\ldots]$

And each column, season, re-enacts Harrapa, Pataliputra. ${ }^{8}$

And every mimosa that infolds within, infolds

207-foot, 1010-tonne iron ship. By the time the shipwrecked passengers were brought to safety, 59 had drowned, and eleven more died within a week while being treated. Others were rescued by Fijian villagers.

7 'Bihari' is a demonym given to the people from the state of Bihar in North India. Many migrants to Fiji hailed from Bihar.

8 Harappa was an ancient city in the Indus civilization (3300-1300 BCE), currently a part of Pakistan. Patliputra (built in 49 o BCE) was an ancient Indian city near modern-day Patna, Bihar. 
A part of the racial memory. (Mishra 1987:23)

In this poem titled 'Canefield', Mishra traverses layers of memories and re-creates the images of estrangement that the Biharis would have experienced while working on the fields - a memory that continues to haunt him, though he did not experience indenture directly. By taking the readers through different temporal planes, the understanding of intergenerational memories gets extended even to ancient civilizations and the racial history of the Bihari labourers working on the fields. In 'Glacier', which was written during his travel to Aotearoa, South Island, the poet is asked by a stranger to describe the glacier in front of him. Instead of describing the glacier, he relives the pain of his ancestors who drowned at sea:

But I'd leap back in time by a hundred

Years, coolie-boy held in talons of fear,

While salt raged, riving the reef to Syria. (Mishra 2002: 54)

As important it is to remember the past because it is instrumental in shaping the present and future, memories are storehouses that are not fixed in time and space: they travel and change with time. As Daniel Levy states, 'A shared sense of the past becomes a meaning-making repository which helps define aspirations for the future' (2016: 291). They cannot be stored securely and neatly, and therefore cannot be retrieved without intervention, or without being processed. This reflects Hirsch's discussion of postmemories as a set of recollections that take place through imaginative investment, rather than being directly connected to the past like memories are. 'Full or empty, postmemory seeks connection. It creates where it cannot recover. It imagines where it cannot recall. It mourns a loss that cannot be repaired' (Hirsch 2012). Mishra's poems are an imaginative rendition of such postmemories that do not mourn the loss of an ancestral land in India so much as they mourn the dislocation and trauma that his ancestors experienced upon arrival and working in Fiji. For instance, when Mishra undertakes an actual physical journey to India, he pens these lines while waiting in a retiring room:

A brisk language connects me to India;

I'm my ancestor fleeing its famine.

Looking in the mirror I see only him,

The young girmityas departing India. 
In India trying to get away from India.

I'd ride a reindeer to get away from India. (Mishra 1994: 42)

While journeying through India, Mishra can only imagine a young girmitya departing from his famine-ridden homeland. There is no sense of nostalgia, longing, or even satisfaction at having visited India, because he does not associate India with the idea of a homeland.

Diaspora as a social form is fluid and unsettled, historically linked to forgetting, remembering, and imagining an identity attached to ancestral land while simultaneously seeking membership in another host land. As opposed to the nation, which is defined by exclusive boundaries and fixed borders, diaspora is based on geographical dislocation or migration. There is distinct movement in terms of time, space, and location: a movement away from a place of belonging. When a community becomes diasporic, everything moves, including memories. The memories of a diasporic community also travel with them, becoming displaced from the point of origin and altering with time and space. Thus, when examined from the binary perspective of the nation and diaspora, national memory is natural, coherent, authentic, and homogeneous, while diasporic memory is hybrid, broken, and displaced. Therefore, Mishra challenges Hirsch's presumption that a diaspora is always attached to a former territorial home by identifying himself as a transnational poet with a blend of multiple identities. The borders of a nation do not confine the identity of a multifarious poet like him, who articulates himself and his identity from several locations, moving restlessly between Fiji and Scotland, Australia and New Zealand, Malta and Italy (Mishra 2002: back page). For instance, in his poem 'Venice', Mishra oscillates between memories of Marco Polo in the spring of 1271, to those of Dante Alighieri in 1321, and then six centuries later to those of a runaway from a slum in Agra, India. As the long poem progresses, the historical characters live out their lives, while that of the runaway Indian transforms in hue:

\footnotetext{
Exhausted by memories, Kabir julaha ${ }^{9}$

came to inside a vase-hipped trough

where matter changed to spirituous glass

without form, mass, weight, music,

so that everything was pure miasma:
}

9 The Kabirpanthi Julaha are a Hindu caste mainly found in the northern Indian state of Uttar Pradesh. The word julaha means a 'ball of thread' in Persian; their main profession is weaving cloth on handlooms. 
warp, breath, camber, sag, texture.

in that hueless space he alone was hue.(Mishra 2002: 8)

The temporal shifts in the narration of the poem create temporal and cognitive discrepancies and ambiguities where meaning making is based on unstable fragments of memory, which leads to questioning the stability of the narrator's identity. The distractions offered by these memories of different times and spaces make Mishra a multi-faceted diasporic poet, who, as Rosemary George believes, does not yearn for assimilation into the mainstream discourses of citizenship and belonging. She writes, 'While the desire for assimilation into the mainstream is popularly read as the trademark of the immigrant experience, "feeling at home" may not require assimilation. At the same time, the process of making oneself at home is a project that may not be completed even by several successive generations' (George 1999: 184). Mishra is not a migrant in Fiji; he was born and raised in Fiji. However, his ancestry is Indian, and time and time again he is made aware of it, and therefore questions whether assimilation in terms of 'feeling at home' can ever happen for the Indo-Fijians.

\section{Conclusion: Fragmented Homes}

Given this ambivalent relationship between Indo-Fijians and the land of Fiji, it becomes difficult to posit the idea of 'home' and 'host' - making conventional ideas about homeland and belongingness problematic. In the case of Indo-Fijians, the margins of home and non-home appear blurred as the ghosts of girmit and coups mingle with each other, giving rise to an acute sense of alienation and dislocation. The more borders are crossed, the more they seem to increase along the lines of race and ethnicity, and multiple coups reiterate this ambivalent state of being. These borders come to life through the everyday experiences of individuals and memory narratives expressed through different mediums of communication. With a fragile and chaotic history, it becomes interesting to study the effects of border crossings on Indian Fijians, for whom the experiences of immigration and exile constantly intermingle. Homi Bhabha, a contemporary postcolonial theorist and writes, 'Where, once, the transmission of national traditions was the major theme of a world literature, perhaps we can now suggest that transnational histories of migrants, the colonized, or political refugees - these border and frontier conditions - may be the terrains of world 
literature'. ${ }^{10}$ This is precisely where one can locate Mishra's work. Modern diaspora disrupts the apparent closure of home and generates transnational, translocal communications and communities, redefining new dimensions of home as a space of becoming rather than being. Even if one lays claim to being an Indo-Fijian, the idea of home transcends the boundaries of Fiji, giving way to a decentred, diverse expression of transition and belonging. For a diasporic poet like Mishra, different cultures constantly intermingle and engage with each other in a dynamic way, where each location's history and geography create newer ways of thinking about nation, region, and territory.

This idea captures the essence of Mishra's writing, the way his poetry is unstructured, broken, and erratic. His poems subvert the genealogy of structured time and expression, often making them obscure and difficult to comprehend, reflecting his state of being a wanderer, a nomad. In his poem 'Memory of Jarek Woloszyn', Mishra expresses,

A world that began with the drought in Basti,

Then forever turned molten as the Danube ${ }^{11}$

Caught the trades at Kidderpore

And cut through the aspy addery braids of Kali.

Now I roam stateless, looking for the resolute world

In a world that is no more

Or no less than the sea (Mishra 2002: 42)

Boundaries survive through their presence. Like the phoenix, they constantly re-create themselves only to be broken down and come back to life again. In a fragmented Fijian society that oscillates between being a democracy and a military-run nation, multiple coups over twenty years have caused internal divisions of race and power to thrive and multiply. ${ }^{12}$ In

10 Bhabha borrows the concept of 'unhomely' from Freud and calls it a paradigmatic colonial and post-colonial condition, describing how the boundaries between the public and private spheres collapse, giving rise to disorientation. He discusses how the 'unhomely' informs the traumatic ambivalences of personal, psychic history to the wider disjunctions of political existence. He believes that 'unhomely' is the condition of the modern world and, taking this as a point of departure, one can argue that Mishra's works depict the state of the modern diasporic, transnational poet (Bhabha 1994:17).

11 Reference to the ship Danube, which had 149 girmityas on board on 15 June 1891. In 1892 she went missing, and her fate is still a mystery.

12 The constitutional crises started on Friday, 10 April 2009, when the Fijian President announced nationwide through radio broadcast that he was abrogating the Constitution of Fiji. He also announced emergency rule, which led to media censorship and increased police powers. 
an essay describing the state of the society during the post-coup elections of 2001, Lal writes,

The fabric of national society has been strained. Although on the surface things look calm - people go about their business, intermingle in their workplace, on the sports field, around the yaqona ${ }^{13}$ bowl, more visibly in parts of Fiji not directly traumatized by the events of 19 May [2000] - but hidden behind the rhetoric of multiculturalism and reconciliation lie deep suspicions and raw prejudices, more widespread now than in Fiji's recent past. (Lal 2005: 210)

Sudesh Mishra's poetry holds a mirror to this unrest, giving voice to the people and events that are otherwise forgotten in everyday life. Through his narratives, the reader gets a sense of the fragmentation and dislocation that mark the lives of Indians in Fiji, and at the same time the hybrid nature of his poetry draws similarities between disparate forms that conjure the ghosts of the past, uniting the community through an invocation of postmemories.

In his preface to Diaspora and Difficult Art of Dying, Mishra states that the structuring principle to that volume of poetry is founded on discontinuities, rather than continuities. This is brilliantly portrayed in his prose-poem of the same name, which spans different locations ranging from a village in India to a ship carrying girmits, to the lands of Fiji, Edinburgh, and Australia. The poet metamorphoses into different genders, characters, and professions to show the fluidity of borders (which is ironic, since borders have been established very strongly in Fiji) and diaspora. The text is one piece of prose, not broken by stanzas or breaks until the end to signify the end of the journey, which in turn, signifies the end of the text. Mishra's prose-poem is sparsely punctuated, with diverse images, interspersed with Hindi and Fijian words and scattered with different thoughts, clearly indicating the state of Indo-Fijians. He says, 'so it was little by little i went through another sea-change as my discovery of an oceanic present leaked into my memory of an indian past, until a time came when i could no longer think of machli ${ }^{14}$ as word and idea and culture had never existed prior to ika ${ }^{15}$, prior to my life on this archipelago, and yet one was forever inside and around the other' (Mishra 2002: 75). While Mishra laments the coup-ridden state of Fiji, he

13 Yaqona, or kava as it known, is a traditional national drink of Fiji associated with a social gatherings, festivities, and rituals. It is also presented as a traditional gift to visitors.

14 Machli means 'fish' in Hindi.

15 Ika means 'fish' in Fijian. 
also celebrates the creative space that the exilic experience offers. The ability to write from within and without, as both insider and outsider, gives Mishra the perspective of a transnational writer, an approach that might best describe his diasporic state. In times that speak of global identities and transnational economies, the study of home breaks away from the conventional understanding of nation and nationalism. Henk van Houtum explains that the national border is a symbolic demarcation of an appropriated space, an imagined truth, that is reproduced symbolically, semiotically, and formally every day in time and space. Therefore, it is a fabrication - a fantasy to which communities seek belongingness. It is through seeking national membership that communities achieve a sense of being a part of the meaningful, collective making of national narratives. A nation thus creates borders that demarcate the rest of the world as the 'other', against which protection is to be sought and distance to be maintained. Borders are hence 'partial, selective and opportunistic', created to fill a void in one's own rootedness and self and identity. Consequently, the dreams of a national utopia based on shared narratives, spaces, and fantasies create internal power struggles of control that are never-ending (van Houtum 2011: 56). It can be argued that, far from being geographical in nature, borders in Fiji are mostly historical and psychological and manifest through constant political, social, and psychological tensions between the two communities. The history of colonization and indenture constantly reiterates the presence of borders that cannot be dissolved or reconsidered. However, as van Houtum states, the border is Janus-faced, in that it offers the potential of mobility and freedom, a desire to cross over, as much as it reinforces national identity and homogeneity.

Study of the Indo-Fijian diaspora offers dislocated sites of contestation to the homogenizing forces of globalization, creating alternative discourses of borders by being the sites of dislocation and instability. These sites then create the possibility of defining a home for a diasporic community, a home that travels and traverses time and space to become more inclusive and comprehensive. The complicated borders of history and geography in Fiji find their representation through the intergenerational postmemories that extend the memories of one generation to subsequent ones, cutting across and establishing a relationship with the past. It is essential that memories of trauma, conflict, and violence be addressed rather than be forgotten, and silence be articulated instead of being suppressed under official censorship. Lal estimates that the Fijian coups of 1987 polarized a society that had the potential to be multicultural and inclusive, and instead generated violence, social instability, corruption, and censorship - including censorship of 
history and culture (Lal 2000; 2009). To challenge state-controlled censorship that threatens to forget history and relegate it to the margins, it is essential for postmemories to thrive and raise questions of identity and belongingness, so that a possibility of envisioning a present and future can be created. Andreas Huyssen believes that 'The form in which we think of the past is increasingly memory without borders rather than history within borders. Modernity has brought with it a very real compression of time and space. But in the register of imaginaries, it has also expanded our horizons of time and space beyond the local, the national, and even the international' (Huyssen 2003: 4). The poetry of Sudesh Mishra transcends all borders, literal and metaphorical, to arrive at an understanding of home as multidirectional and transnational. His poetry is structurally disjointed, reflecting the nature of diasporic memories, and his engagement with postmemories of indenture bring to the fore the existing borders of ethnic and racial alienation in Fiji.

\section{References}

Anderson, B. (1991). Imagined Communities. London: Verso.

Bhabha, H. (1994). Location of Culture. London: Routledge.

George, R. (1999). The Politics of Home. Berkeley: University of California Press.

Hirsch, M. (1992). Family pictures: Maus, mourning, and post-memory. Discourse, 15(2), p. 3-29.

- (1996). Past lives: Postmemories in exile. Poetics Today, 17(4), p. 659-686.

- (1997). Family Frames: Photography, Narrative, and Postmemory. Harvard University Press.

Huyssen, A. (2003). Present Pasts: Urban Palimpsests and the Politics of Memory. Stanford: Stanford University Press.

Lal, B. (200o). Fiji Before the Storm: Elections and the Politics of Development. Canberra: Australian National University Press.

- (2005). Bittersweet: The Indo-Fijian Experience. Canberra: Pandanus Books.

- (2009). Indo-Fijians: roots and routes. In: R. Rai and P. Reeves, eds., The South Asian Diaspora: Transnational Networks and Changing Identities. London: Routledge, pp. 89-109.

Levy, D. (2016). Cosmopolitanizing catastrophism: Remembering the future. Theory, Culture \& Society, 33(7), pp. 291-299.

Mishra, S. (1987). Rahu. Fiji: Universal Printing Press Limited.

- (1992). Tandava. Melbourne: Meanjin Press.

- (1994). Memoirs of a Reluctant Traveller. Adelaide: CRNLE/Wakefield Press.

- (2002). Diaspora and the Difficult Art of Dying. New Zealand: Otago Press. 
Mishra, V. (2007). Literature of the Indian Diaspora: Theorizing the Diasporic Imaginary. New York: Routledge.

Nandan, S. (2000). Fiji: Paradise in Pieces. Flinders: Flinders University Press.

Srebrnik, H. (2008). Indo-Fijians: Marooned without land and power in a South

Pacific Archipelago? In: P.Raghuram, A. Sahoo, B. Maharaj, and D. Sangha, eds., Tracing an Indian Diaspora: Contexts, Memories, Representations. London: Sage, pp. 75-95.

van Houtum, H. (2011). The Mask of the Border. In: D.W. Walter, ed., The Ashgate Research Companion to Border Studies. London: Ashgate, pp. 49-63.

\section{About the Author}

Tana Trivedi is a Senior Lecturer of English Literature and Communication at Ahmedabad University, Gujarat, India. Her areas of research are the Indo-Fijian literature of diaspora, memory studies, and postcolonial studies. 


\title{
Conclusion
}

\author{
Md. Azmeary Ferdoush and Reece Jones
}

Jones, Reece and Ferdoush, Md. Azmeary (eds), Borders and Mobility in South Asia and Beyond. Amsterdam: Amsterdam University Press, 2018 DOI: $10.5117 / 9789462984547 /$ CONCL

\section{Partition's Borders}

The partition of British India illustrates how the decisions of a few people over a very short period of time can have lasting impacts on the lives of billions of others for many generations. The momentous and calamitous event was enacted within a two-month period in the summer of 1947 and relied heavily on the judgement of a single man, Sir Cyril Radcliffe, who had never even visited India prior to his appointment as the head of the Boundary Commission that would decide the permanent borders for India, Pakistan, and eventually Bangladesh (Chatterji 1999). To perform this mammoth task, the commission had only six weeks and Radcliffe started drawing the line on the map without any empirical knowledge of the people living along that borderscape (van Schendel 2005; Whyte 2002). The result of this cartographic scissoring was not only the mass migration and violence immediately following Partition, with over a million deaths and over ten million more people displaced, but also the long-term impacts on the lives of those who had no choice but to live with the new territorial limits to their idea of home. The quickly made, and often ill-informed, decisions of that fateful summer 70 years ago continue to shape the daily practices, politics, religion, economy, and culture of both those who reside in South Asia today and those who have migrated to distant homes. Those imagined lines on the map are the increasingly hardened borders over which guards nervously eye each other, on which civilians risk their lives to work their land, and about which politicians experience cartographic anxiety over how firmly they control the allegiance of the people and territory (Krishna 1994). Those lines also are the departure point for the millions of people who have set out in search of better opportunities elsewhere in South Asia, the Middle East, Europe, North America, and the South Pacific.

South Asian borders have a complex and significant history, but are at times overlooked by scholars in the field of border studies and allied disciplines. 
However, the legacy of arbitrary borders left behind by colonists and the subsequent decades of conflict between the various states over the territorial extent of their sovereignty creates an ideal location for interrogations of state categories of power, place, and identity (Chester 2008, 2013; Cons 2016; Jones 2009; Samaddar 1999; Shewly 2013; Sur 2013; van Schendel 2005; Whyte, 2002; Zamindar 2007). While some of the borders in South Asia are among the most violent in the world, others are still wide open and feature crossborder flows and connections. Even the most securitized sections - along the India-Pakistan border and the West Bengal-Bangladesh border - divide people who share an ethnic, linguistic, and cultural history. Similarly, the meaning of these lines to people on the move, and to those living permanently in distant lands, are fraught and complex. The borderlines of South Asia do not represent ancient polities that have always been in conflict, but are instead examples of how new territorial states are written over, across, and through other histories, ancestral lands, and identities. In turn, these borders, histories, and identities continue to shape the complex interplay between place and mobility for the people who find their lives contained by them.

This book is an indication of the productive nature of South Asian borders as it sheds light on how people experience and negotiate borders in their daily lives, how borders restrict human mobility, how certain movements are branded as legal and others are not, and how borders influence the diasporic population of South Asia. The three sections of the book offered three distinct lenses to understand the consequences of borders in South Asia and beyond. The first section, 'Experiencing Borders in South Asia', delved into the lives of the people who continue to live around and along the borderlands 70 years after Partition. The second section, 'Mobility in and beyond South Asia', analysed the experiences of people on the move who undertook journeys for work, for better opportunities, or to escape violence in their homes. The final section, 'Representations of Borders and Mobility in Diaspora', suggested that people with ancestral connections to South Asia produce and reproduce the borders of the nation and the state through their actions, imagination, and language. In the process, they reimagine their sense of identity, their connection to place, and their idea of home.

\section{Arguments and Implications}

The book began with the question: In an age of global migration, economic flows, and information exchange, how do borders and restrictions on mobility affect the lives of people from South Asia and beyond? The multiple 
perspectives in this book can be distilled down to three primary answers to this question. First, despite hardened and violent borders, people still find ways to move, often ignoring the rules of the state and risking their lives by taking ever more dangerous routes. The first two chapters of the book use the productive South Asian borderland spaces to develop new theoretical insights such as spaces of refusal and layered borders. Second, gender affects the migration experience both en route and in the opportunities in the destination countries. These impacts are evident at all stages of the process, from who is able to migrate, to how they are treated in transit countries, to how they are perceived by other migrants and locals in their new homes. Third, diaspora populations continue to renegotiate their connections to their place of residence and ancestral home for generations after migrating as the relationship between place and identity evolves. This conclusion considers the broader implications of these findings.

Many of the chapters demonstrated that the situation for migrants has become more challenging in the past 30 years as states around the world crack down on migration and make movement more difficult. The hardening of borders is evident in South Asia, where barbed wire fences, floodlights, and aggressive security forces patrol borders, as Chapter 4 by Kavitha Rajagopalan illustrated. It is also evident at the borders that migrants encounter along their journeys to the Middle East and Europe. In an age of globalization, states take full advantage of technology to 'secure' their borders in every way possible, including powerful cameras, motion sensors, and drones, as described by Marta Zorko in Chapter 8 (Jones 2016). In tracing the relationship between people on the move and the state, this volume contributes to a growing body of scholarship that demonstrates that bordering and borderwork do not only happen at borders, but also at many locations within and beyond the territory of the state (Johnson et al. 2011; Jones and Johnson 2014; Amilhat-Szary and Giraut 2015). This experience is not only restricted to mundane interactions such as showing a passport in the airport or buying a new cellular data plan in a foreign country, but is also evident in the violence perpetrated on vulnerable migrants by police and smugglers, the constant fear of being deported once a migrant arrives in their destination country, and the inability to get a good job without the proper papers.

This book shed light on these journeys by telling the stories of people who moved in search of better opportunities elsewhere and demonstrated how the hardening of regional borders can have an effect on the patterns and demographies of migration from South Asia to the Middle East and 
Europe. Micronarratives, such as the stories of the Lushai people navigating the border in Chapter 3 by Azizul Rasel or Akbar's journey detailed by James Weir and Rohullah Amin in Chapter 7, offer valuable insights into the borderwork produced by interactions with families at home, smugglers, border guards and police, and other migrants encountered on the route. These first-hand accounts demonstrate that borders are not only situated at the edge of the state, but could also materialize at many other locations, depending on whose body is on the move (Rumford 2006; Butler 2011).

Despite the hardening of borders and the anti-migrant sentiments in many countries, people around the world continue to defy arbitrary restrictions on their movement. Borderlanders experience, negotiate, transcend, and make meaning of borders based on their own subjective positionalities. In doing so, borderlanders make borders the sites of not only overt and covert defiance, but also of opportunity (van Schendel 2005). From cross-border trips to the market to longer labour migrations, people find ways to get to the place they need to go to be reunited with family or to seek better opportunities for themselves and their children. The contributors to this book peered into the cracks in the walls of the state and opened up spaces of refusal where people opted to ignore or redefine the borders imposed by the state and continued to live their lives as they desired. In some instances, this also meant that states are forced to create spaces for cross-border connections, as Edward Boyle and Mirza Zulfiqur Rahman demonstrated in Chapter 2. Although the total trade in the cross-border haats is minuscule compared to trade through the regular ports, both India and Bangladesh have taken on the burden of facilitating them. Their existence, particularly along a border that has been fenced and militarized in the past twenty years, illustrates the important role borderland residents can play in negotiating and shaping the nature of the border.

The second finding of the book is that the experience of migration is often gendered as people face different challenges based on societal norms and beliefs about who should have the right to move and work. In South Asia and the Middle East, there is a persistent stigma associated with leaving home and becoming independent that discourages many women from making the trip and harms those who do. Women face more obstacles to migration and are more vulnerable to formal and informal rules and laws. In Chapter 5, Ananya Chakraborty described the experiences of Bangladeshi women working in India and in Chapter 6 Andrea Wright demonstrated the obstacles Indian women face even before they leave home as colonial laws and contemporary attitudes about gender roles impede their ability to migrate to the Middle East for work. 
For South Asian men who migrate to Europe, particularly Muslim men, the stigma of terrorism shapes interactions with host country residents who fear the straw man of how they believe Muslims act and what impact they will have on the local culture. These gendered biases affect the ability of migrants from South Asia to completely access opportunities and integrate into new host communities. In Chapter 9, Malini Sur and Masja van Meeteren detailed the challenges faced by migrants from Bangladesh for years after arriving in Belgium. Their lack of papers, the difficulty of finding good jobs, and the stigma of terrorism all made their lives difficult, but they worked together to protest the situation and raise local awareness of their plight.

The third finding of the book is that even for South Asian migrant populations that have lived for long periods in new homes, there is a constant process of rethinking and reconsidering their place in the world. Many migrant and diaspora communities retain connections with distant relatives for decades through remittances and the performance of identity in their new society in relation to other groups (Rahman and Yong 2015). These contested visions of place, homeland, and identity are often evident in poetry and prose, as well as in how past events are memorialized and remembered by diasporic communities. Partition has been the subject of many books, films, and plays, but there is also a growing literature that investigates the lingering impact of cross-border movements and divided identities in the decades since the imposition of borders in South Asia.

Borders have moved from the edge of the state to locations throughout the interior and exterior of the territory (Jones and Johnson 2014). The spread of borderwork to many new locations results in a transformation of how people on the move imagine place and their position within it. The process of placemaking involves their daily activities, their interactions with local people, their struggle to make a livelihood, their efforts to work around the system, and their attempt to learn new languages. The longing for the place left behind is always there and is often expressed in the forms of collective memories, literature, celebrating different events, memoirs, and building monuments. In Chapter 10 Riddhi Shah considered the forgotten history of Indian Ocean slave trading, and in Chapter 11 Tana Trivedi illustrated this ambiguity through the poetry of Sudesh Mishra, who details the unique sense of home for the Indo-Fijian community. In sum, the third section of the volume demonstrated through memories and literature how a sense of place and belonging is negotiated and redefined in the South Asian diaspora around the world. 


\section{Final Thoughts}

The overarching theme that links these chapters together is an awareness and concern with how the arbitrary lines on the map of partition - and their increasingly militarized and violent borders on the ground today - shape the movement, identity, connections to place, and sense of belonging for people of South Asian descent, both within the region and around the world. The borders of states are a jumping-off point for many of these discussions, but a state-centric approach is not enough to draw out the dynamic picture of mobility in the contemporary world. It might provide a partial picture of formal actions, for instance, the making of categories such as citizens, residents, aliens, legal, and illegal, or of policies for cross-border trade and investment. However, a focus only on the story of the state would miss the perspective and narratives of the people who move across borders on a daily basis. This book told many of these stories, from farmers who cross the border informally to participate in a border market to people of South Asian descent who have lived for generations in diaspora, deposited halfway around the world by the colonial machine. Every borderland community has their own narratives, lifestyles, and actions that are connected to the notion of the line, but that are distinct and based on the sense of place where they reside. A clear understanding of state and local discourse and practices, as well as an analysis of how those discourses and practices align, conflict, or even combine on a daily basis, is necessary to grasp the subtleties of any given border on the ground.

The objective of this book was to engage with the dynamics of life along the borders of South Asia, on the migrant routes to distant lands, and in the diaspora communities of temporary workers and permanent residents. The chapters focused on notions of citizenship, identity, and belonging, often drawing on the lives and stories of minority populations living both in South Asia and in the diaspora. Together, they develop a broader fabric of experience that deepens our understanding of how borders and mobility are shaping and reshaping the lives of people in South Asia and beyond. Despite the stories of cross-border movement and connection that fill this volume, borders also divide people by granting legitimacy and rights to some while excluding many others from equal access and protection to the law. At the most basic level, borders are a system of controlling resources and opportunities and excluding others from the same. These border effects are produced by the political actions of different state and non-state actors who perform the sovereignty of the state and enact the rules that give power to lines on the map. It is this relationship between the map, the border, 
the land, and the people who move across it that shape the chapters of this book, and that will continue to be a focus for scholars of borders and mobility for years to come.

\section{References}

Amilhat-Szary, A.-L. and Giraut, F. (2015). Borderities and the Politics of Contemporary Mobile Borders. London: Palgrave Macmillan.

Butler, J. (2011). Gender Trouble: Feminism and the Subversion of Identity. New York: Routledge.

Chatterji, J. (1999). The fashioning of a frontier: The Radcliffe Line and Bengal's border landscape, 1947-52. Modern Asian Studies, 33(1), pp. 185-242.

Chester, L. (2008). Boundary commissions as tools to safeguard British interests at the end of empire. Journal of Historical Geography, 34, pp. 494-515.

Chester, L. (2013). Borders and Conflict in South Asia: The Radcliffe Boundary Commission and the Partition of Punjab. Manchester: Manchester University Press.

Cons, J. (2016). Sensitive Space: Fragmented Territory at the India-Bangladesh Border. Seattle: University of Washington Press.

Johnson, C., Jones, R., Paasi, A., Amoore, L., Mountz, A., Salter, M., and Rumford, C. (2011). Interventions on rethinking 'the border' in border studies. Political Geography, 3o(2), pp. 61-69.

Jones, R. (2009). Agents of exception: Border security and the marginalization of Muslims in India. Environment and Planning D: Society and Space, 27, pp. 879-897. Jones, R. (2016). Violent Borders: Refugees and the Right to Move. New York: Verso. Jones, R. and Johnson, C. (2014). Placing the Border in Everyday Life. New York: Routledge. Krishna, S. (1994). Cartographic anxiety: Mapping the body politic in India. Alternative: Global, Local, Political, 19(4), pp. 507-521.

Rahman, Md. M. and Yong, T.T. (2015). International Migration and Development in South Asia. London: Routledge.

Rumford, C. (2006). Theorizing borders. European Journal of Social Theory, 9 (2), pp. $155-169$.

Samaddar, R. (1999). The Marginal Nation: Transborder Migration from Bangladesh to West Bengal. Dhaka: The University Press Limited.

Shewly, H.J. (2013). Abandoned spaces and bare life in the enclaves of the IndiaBangladesh border. Political Geography, 32, pp. 23-31.

Sur, M. (2013). Bamboo baskets and barricades: Gendered landscapes at the India-Bangladesh border. In: B. Kalir and M. Sur, eds., Transnational Flows and Permissive Polities: Ethnographies of Human Mobilities in Asia. Amsterdam: IIAS Publications, pp. 127-150. 
van Schendel, W. (2005). The Bengal Borderland: Beyond State and Nation in South Asia. London: Anthem Press.

Whyte, B. (2002). Waiting for the Esquimo. An historical and documentary study of the Cooch Behar enclaves of India and Bangladesh. Melbourne: Research Paper, 8. Available https://minerva-access.unimelb.edu.au/handle/11343/34051 Zamindar, V. (2007). The Long Partition and the Making of Modern South Asia: Refugees, Boundaries, Histories. New York: Columbia University Press.

\section{About the Authors}

Md. Azmeary Ferdoush is a Lecturer in Sociology at the University of Dhaka, Bangladesh and a Ph.D. candidate in Geography and Environment at the University of Hawai'i at Mānoa. He is an East West Centre Graduate Degree Fellow. His research interests include, but are not limited to, borders and enclaves with a focus on Bangladesh and India, social theory, political geography, (non)citizenship, state, and migration. He has published several peer reviewed journal articles and book chapters on borders and enclaves, and his op-eds have been featured in the Daily Star and the Dhaka Tribune.

Reece Jones is a Professor of Geography and Environment at the University of Hawai'i at Mānoa. He is the author of two books, Border Walls: Security and the War on Terror in the United States, India and Israel (2012, Zed Books) and Violent Borders: Refugees and the Right to Move (2016, Verso). He also edited Placing the Border in Everyday Life with Corey Johnson (2014, Routledge Border Regions Series) and Open Borders: In Defense of Free Movement (2018, University of Georgia Press). 


\section{Index}

Aadhar card 139

Aaya ('nanny') 148

Acharya, Gunvantrai 23, 229, 232-245

Adivasi ('indigenous') 22, 52-53, 81-82, 85-90

Afghan/Afghanistan 11, 15, 21, 167-177, 180-183, 194, 198-199

Africa 11, 23, 81, 118, 196, 198, 210, 219, 229-234, 239-245

Agamben, Giorgio 33, 41-42, 46, 55, 71

Agency 115, 123-126, 128, 130, 140, 173

Agent, Labor recruiting 132-135, 137, 139, 147-151, $160-161,168,176-177,213-214,256$

Aizawl 91-97

Amnesty International 145-156

Animist/animism 85

Antwerp 126, 208-210, 213, 215, 217-224

Assam 64-65, 68-70, 76, 83, 91, 113, 130

Asylum 12, 15, 111, 168, 174, 180-184, 191, 193, 195-196, 199, 201, 208-221, 224-225

Australia 21, 23, 102, 118, 249-252, 260, 263

Austria 176, 178, 182

Bahrain 145, 159

Balkans 11, 188, 190-192, 195

Bangladesh 11-12, 15-23, 31-32, 34, 38-40, 42-46, 48-53, 59-61, 63-76, 81-83, 86-88, 90-95, 101, $103,105,107-111,113-117,123-131,134,136-140$, $152,194-195,198-199,207-225,233,267-268$, 270-271

Bare life 33, 42, 49, 71

Belgium 23, 207-225, 271

Belonging 17-22, 101-108, 110-12, 114-115, 118-119, $137,207-208,219,223,250,255^{-257}, 260-265$, 271-272

Bharat Mata 256

Bhutan 101-104, 108-109, 112-116

Bharatia Janata Party (BJP) 69

Biopolitics 33

Border Guard Bangladesh (BGB) Formerly known as Bangladesh Rifles (BDR) 38, 41-45, 73, 91, 93

Border layer 59, 61-62, 73-76

Border Security Force, India (BSF) 38, 43-46, 73-74, 93

Borderland 13, 17-18, 21-22, 31-32, 38-46, 49, $5^{2-55}, 69,71,73-76,81-82,95,112,115,129$, $196,255,268-272$

BREXIT 198, 201

Brubaker, Rogers 47-48

Buddhist/Buddhism 85, 102, 112-113, 170

Bulgaria 170, 176-179, 190, 192

Calcutta $38,153,251,257$

Camp 15, 41, 91, 102, 108, 110, 112, 181, 188-189, $192-196,215,220-221$
Canada 15, 102, 107, 151, $25^{2}$

Caste 111, 116-117, 232, 239, 255, 260

Chatterji, Joya 16-17, 37-38

China 66, 71-72, 79, 84, 110, 113

Chittagong 213, 215

Chittagong Hill Tracts (CHT) 22, 81-95

Christian/Christianity 6o, 85, 112, 181, 232

Citizenship 13, 19, 22-23, 42-44, 91, 93, 101-119, $139,146,155,154-159,161,198,207-212,216$, 220-225, 250, 252, 261, 272

Civic participation 207-209, 225

Cold War 20, 70, 168, 171, 190, 200

Colonial/Colonialism 11, 13, 16-18, 38-39, 81-89, 9495, 103-104, 109, 128-129, 145, 147, 154-159, 198, 221, 232, 239-240, 250-253, 255, 261, 270, 272

Congress Party 69

Croatia 21, 182, 187-196, 199

Cultural trauma 244-245

Dalal ('broker') 124-127, 130, 132, 213

Dariyalal 23, 229, 232-245

De Genova, Nicholas 208

Denmark 102

Dhaka 61, 71, 87, 93, 127, 213, 218

Diaspora 13-15, 19, 23, 47, 103-104, 107, 110, 116, $119,205,229,249-251,260-264,268-272$

Discourse 40, 51, 62, 73, 75-76, 94, 125, 131, 139, 152-156, 161, 189-197, 200-201, 217-218, 233, $244,255,261,264,272$

Double segregation 131

Dubai 146, 149, 153, 160, 213, 215

Emigration 11, 22, 102-103, 110, 115, 145-162, 233

Eritrea 11

Ethnicity 13, 37, 47, 52, 81-86, 92-95, 101, 103-104, 107-109, 112-113, 116-117, 126, 129, 170-171, 213, $249-255,261,265,268$

Eurocentric 183, 229, 233-234, 243

Europe 10-15, 19-23, 36-39, 52, 109-110, 116, 119, 153-154, 167-169, 172, 174-179, 182-183, 187-201, 207-225, 231-236, 239, 252, 267, 269-271

Fast transit 192

Fence 15-16, 32, 39, 42-45, 62, 69-75, 90, 191-192, $197,200,255,269-270$

Fiji 23, 249-265

Flemish 217-218, 220-223

Frankfurt 22, 167, 169-170, 178-179

Frontier 84, 213, 261

Gender 13, 22, 123-124, 129, 133, 136, 140, 145-146, $148-149,154,160-161,213,255,269-272$

Geopolitics 187, 191

Germany 12, 167-170, 172, 177-183, 187-188, 190, $192,196,198$ 
Girmit ('indenture') 250-251, 254, 258, 261

Globalization 14, 101-106, 112, 140, 213, 249, 264, 269

Greece 188, 191-192

Gujarat 229-232, 237, 241, 244

Haat ('market') 64, 67, 69, 73, 76

Hegemony $115,25^{2}$

Hijab ('head covering') 161

Hili 44, 50, 61

Hindu/Hinduism 37-38, 51-52, 85, 102, 111-112, $116,126,139,156,229,232,234,237,239-243$, 256,260

Home 12, 20-23, 31, 47, 102, 114, 132, 135, 138-139, $156,158-161,169-174,188,218,220,239$, 249-250, 253-265, 267-272

Hungary 178, 187-188, 191-192, 197

Illegal 40, 42-44, 63, 108, 111, 113, 115, 117, 131, 145$147,151,155,208-209,211,215,219-223,272$

Immigration 21, 90, 111-112, 115, 117-119, 155, 180, 198-199, 211-215, 218-219, 261

Immoral Traffic (Prevention) Act 145, 149, 158-161

Indenture see girmit

India 15-18, 21-23, 31-34, 37-53, 59-7 6, 81-86, 90-95, 101-107, 109-113, 115-119, 123-140, $145-153,156-162,189,198,229-233,237,239$, 245, 251, 256-26o, 263, 267-270

Indian Ocean 23, 229-232, 234-238, 240, 271

Indo-Fijian 249-250, 253-254, 263-264

Integration 23, 70, 114, 129, 140, 194, 196, 200-201, 207-213, 217, 219-221, 224-225

Iran 168-172, 175-178, 195, 222

Islam see Muslim

Islamic State 171, 173, 175

Italy $11-12,23,110,197,199,260$

Jhum ('shifting agriculture') 85,88

Jihad 171

Kabul 22, 167-180, 183

Kala Pani ('black sea') 240

Khagrachhari 88, 92

Khasi $60-63,65,67,69,71,73$

Kibria, Nazli 20, 111, 198

Kuwait 128, 145, 159

Land Custom Station (LCS) 63-64

Lhotshampa 102-104, 112-115

Libya 11-12, 110

Liminality $42,112,115,124$

Lushai 81-95

Maharashtra 22, 123, 126, 133, 137-139

Malaysia 20, 110

Map 13, 17-18, 37-38, 53-55, 62, 67, 83, 107, 267, 272

Marginal 34, 37, 40, 82, 125, 133, 140

Marginalized 82-83, 85-86, 92, 94, 103, 208, 213
Meghalaya 22, 59, 63-65, 67-69, 73

Memory 20-21, 23, 60, 102, 170, 229, 231, 237-238, $240,245,249-250,254-255,258-263,265$

Mensen zonder papieren ('people without papers') 209, 213-214, 217, 222, 224

Middle East 11, 19-20, 22, 123, 128, 152, 154, 171, 267, 269-270

Migration 8, 11-14, 16, 21-23, 42, 45, 47, 70, 73, $82,87,90-93,101,103-105,106-112,114-119$, 123-132, 136-138, 140, 146-151, 153-154, 157-158, 160, 167, 169, 187, 189-192, 194-201, 207-208, 211, 213-214, 219, 222-224, 229, 233, 250-252, $254,260,267-270$

Ministry of External Affairs, India 67, 155, 158-16o

Ministry of Integration, Belgium 219-221

Minorities 85, 201, 208, 253

Mishra, Sudesh 23, 249-250, 253, 263, 265, 271

Mizo Nationalist Front 92

Mizoram 65-66, 68, 81-84, 86, 90-95

Mobility 13-15, 19, 21, 23, 71, 82, 90, 94, 106-107, 116-117, 124, 126-127, 134, 140, 200, 232, 245, $264,268,272-273$

Mozambique 230-231, 239

Mujahedeen 171-172, 174

Mumbai 124, 130, 132-133, 136, 139, 146-148, $15^{0-151,213,222}$

Muslim/Islam 17, 22, 37-38, 51-52, 70, 85, 101, 103-104, 109-112, 116, 119, 126-127, 130, 139, $145^{-147}, 154,156,159,161,171-175,180-181,210$, 213-214, 217, 223, 232, 271

Myanmar (Burma) 11, 15, 65, 68, 71-72, 83-84, 101, 103-105, 108-109, 116

Nation $17,37,39,42,47-48,61,65,71,84-85,104$, 108-109, 112, 114, 116, 156-158, 200, 207-208, $214,218,241-242,245,249-250,252,255,260$, 262,264

National Association for the Advancement of Colored People (NAACP) 231

Nationalism 14, 16, 40, 114, 116, 119, 264

Nepal 82, 101-102, 108-109, 112-116, 152

Netherlands 102

Nested hierarchies 76

New Delhi 61-63, 67, 70-73, 75-76

New Zealand 102, 252, 260

Newman, David 62, 72

NGO 169-170, 174, 209, 212

Norway 102, 177, 197

Oman 145

Oral history 167

Pakistan 15-18, 38, 65-66, 85-87, 91, 128, 157, 168, $170-173,194,198-199,215,267-268$

Paperless 210, 221

Paperwork 207, 209, 211, 214-215, 223, 225

Partition $13,16-18,21,28,38,5^{0-51}, 68,71,81$, $83-86,90-91,127-128,157,267-268,271-272$ 
Passport 39, 53, 102, 125, 130, 159-16o, 214-216, 220, 223, 269

Persian Gulf 107, 110, 145-146, 159-16o

Petty sovereign 34,61

Place 13-17, 19-21, 23, 34, 36-37, 39-42, 54, 61, $63,65,72,75,81,87-88,108,114,116-117,127$, 148-151, 153, 173, 182, 200-201, 215, 232, 235, $243,250,253,256,259-260,268-272$

Portugal 197

Postcolonial 18, 81-82, 89, 94-95, 145, 147, 157-159, 253, 261

Purdah 159-16o

Qatar 145

Quawalli('band') 170

Radcliffe, Cyril 85, 267

Ramjibha 229, 232-243, 245

Rangamati 88, 91-92

Red Cross 194, 221

Refugee 11, 14, 16, 36, 101-104, 109-113, 115-116, $167-172,175,177-183,187-201,207,214$, 216-219, 261, 274

Region/Regional 17, 19, 21, 23, 61-63, 65-66, 7076, 82-84, 91, 101, 103-105, 107-110, 112, 115-119, $124,126,129,138,168,187,189-191,208,217$, 229, 231-232, 236, 241-243, 262, 269, 272

Regularization 208-209, 211-214, 216-217, 219-221, 223-225

Religion 13, 20, 38, 145, 154, 213, 241-242, 255, 267

Remittance 12, 20, 125, 135, 271

Resistance 22, 31-36, 41, 47-49, 54, 62, 73-76, 171-172, 233

Rohingya 11, 103-104, 108-109

Romania 192, 198

Ruilui Para, Bangladesh 86, 91-92

Sajek Valley 8, 82, 84, 86, 88, 89-95

Saudi Arabia 110, 145

Scandinavia 190, 196

Schengen 190, 192, 195, 197, 200

Scott, James 33- 37, 39-40, 203

Sensitive spaces $18,71,73$

Serbia 11, 178, 182, 187-188, 191-192

Shalwar kameez 167

Siddis 232

Silent transit 189, 192

Slave trade 229-235, 238-240, 242, 244-245

Slavery $23,36,104,111,116,118,229,231,234-236$, 238-241, 243-244

Smuggler 45, 46, 151, 167-168, 174-177, 179-18o, 269-270

Smuggling $38,42-43,45-46,50,65,72,102,15^{1}$, 167-168, 175-179, 202

South Asia/South Asian 8, 11-23, 37, 52, 66, 70, $81,85,94,101-104,106-112,115,124,125,129$, $146,152,154,187,189,195,198-199,207-208$, $215,245,267-272$

Sovereignty $7,18,32-39,41-46,49,51-54,70,90$, $224,268,272$
Soviet/Soviet Union 75, 167, 170-172, 182, 185 Spaces of refusal 22, 31, 35, 49, 54, 73, 269-270

Spain 190, 197

Sri Lanka 116, 198

State of emergency 41, 193

State of exception 31, 33-35, 41, 46, 54

Sub-nationalism 217

Syria/Syrian 11, 173, 177-179, 182, 187, 192, 194, 199, 257-259

Taliban 170-175, 180, 182

Territorial phantom pains 17

Territoriality $18,36,39,53,214$

Territory 18, 33, 36-37, 40-42, 44, 46-49, 51-54, 71, $91,108,157,182,191-192,197,262,267,269,271$

Textile 230, 239

Thailand 82

Traffic 110, 119, 124, 145-149, 152-153, 158-16o, 173,222

Trafficking 22, 42, 116-119, 131, 145-147, 149-159, 161-162

Transit 15, 62, 113, 119, 152, 157, 168-170, 181, 188-189, 191-197, 208, 215, 262, 269

Transnational/Transnationalism 18, 23, 32, 47$48,81,90,94,105,146,15^{2}, 249,255,260-265$

Tripura 22, 59, 63-65, 67-70, 74, 82-83, 86, 130

Turkey 15, 168, 177, 191-192, 210, 215

Ulama 156

Undocumented/Undocumentedness 22, 102, 104$107,110,112,115,117,119,123-124,126,129-133$, 135-136, 138-140, 207-211, 213, 218, 221, 224

United Arab Emirates 22, 145-147, 153, 161, 215

United Kingdom (UK) 12, 14, 102, 160, 189, 198

United Nations 11, 14-15, 112, 146, 149, 152, 158, 217

United Nations High Commissioner for Refugees 11, 14, 112

United States 14-15, 20-21, 41, 102, 152-153, 161, 231,252

van Schendel, Willem 16-18, 38, 42, 45, 49, 70-71, $73,75,82-86,91,209,223,267-268,270,274$

Vāniyā 230-231, 239, 241, 243

Violence 11, 16, 18, 33-35, 41-42, 46, 49, 53-55, 101, 110-113, 116-119, 130, 133, 172, 181, 233-236, 241, $252,264,267-269$

Visa $39,61,66-67,114,118,125,151,213$

Vulnerabilities 22, 123-126, 130-133, 136, 140

Vulnerable 22, 103, 106, 117, 119, 127, 130-131, 134, 139-140, 145-147, 149-151, 154-157, 160-162, 172, $182,269-270$

Wall 11, 13-14, 50, 70, 193, 200, 222, 234, 245, 255, 270

West Asia 168

West Bengal 17, 38, 40, 43, 65, 68, 126, 138, 268

Zagreb 195-196

Zamindar, Vazira 16-17, 81-82, 157, 268 
